US Army Corps

of Engineers.

Prepared for the U.S. Army Corps of Engineers, Portland District,

under an Interagency Agreement with the U.S. Department of Energy

Contract DE-AC05-76RL01830

\title{
Evaluation of Fish Passage Conditions for Juvenile Salmonids Using Sensor Fish at Detroit Dam, Oregon
}

\section{Final Report}

JP Duncan

January 2010

\section{Pacific Northwest}

NATIONAL LABORATORY

Proudly Operated by Battelle Since 1965 


\title{
DISCLAIMER
}

This report was prepared as an account of work sponsored by an agency of the United States Government. Neither the United States Government nor any agency thereof, nor Battelle Memorial Institute, nor any of their employees, makes any warranty, express or implied, or assumes any legal liability or responsibility for the accuracy, completeness, or usefulness of any information, apparatus, product, or process disclosed, or represents that its use would not infringe privately owned rights. Reference herein to any specific commercial product, process, or service by trade name, trademark, manufacturer, or otherwise does not necessarily constitute or imply its endorsement, recommendation, or favoring by the United States Government or any agency thereof, or Battelle Memorial Institute. The views and opinions of authors expressed herein do not necessarily state or reflect those of the United States Government or any agency thereof.

\author{
PACIFIC NORTHWEST NATIONAL LABORATORY \\ operated by \\ BATTELLE \\ for the \\ UNITED STATES DEPARTMENT OF ENERGY \\ under Contract DE-AC05-76RL01830
}

Printed in the United States of America

Available to DOE and DOE contractors from the

Office of Scientific and Technical Information,

P.O. Box 62, Oak Ridge, TN 37831-0062;

ph: (865) 576-8401

fax: $(865)$ 576-5728

email: reports@adonis.osti.gov

\footnotetext{
Available to the public from the National Technical Information Service, U.S. Department of Commerce, 5285 Port Royal Rd., Springfield, VA 22161 ph: (800) 553-6847 fax: $(703) 605-6900$

email: orders@ntis.fedworld.gov

online ordering: http://www.ntis.gov/ordering.htm
}

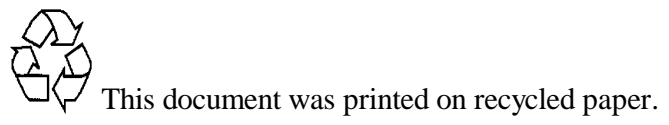




\section{Evaluation of Fish Passage Conditions for Juvenile Salmonids Using Sensor Fish At Detroit Dam, Oregon}

\section{Final Report}

JP Duncan

January 2010

Prepared for

the U.S. Army Corps of Engineers, Portland District, under an Interagency Agreement with

the U.S. Department of Energy

Contract DE-AC05-76RL01830

Pacific Northwest National Laboratory

Richland, Washington 99352 


\section{Summary}

Fish passage conditions through two spillways at Detroit Dam on the North Santiam River in Oregon were evaluated by Pacific Northwest National Laboratory for the U.S. Army Corps of Engineers (USACE), Portland District, using Sensor Fish devices. The objective of the study was to describe and compare passage exposure conditions through Spillbay 3 and Spillbay 6 at 1.5- and 3.5-ft gate openings, identifying potential fish injury regions of the routes. The study was performed in July 2009, concurrent with HI-Z balloon-tag studies by Normandeau Associates, Inc.

Sensor Fish and live fish were deployed at elevations approximately $3 \mathrm{ft}$ above structure at depths determined using a computational fluid dynamics model. Release depth and position were established to introduce the fish and sensors into flow of approximately $5 \mathrm{ft} / \mathrm{sec}$. Spillgate openings of $1.5 \mathrm{ft}$ and $3.5 \mathrm{ft}$ (resulting in approximate flows of 1560 and 3090 cfs, respectively) were evaluated.

Sensor Fish data were analyzed to estimate 1) exposure conditions, particularly exposure to severe collision and shear events by passage route sub-regions; 2) differences in passage conditions between passage routes; and 3) relationships to live-fish injury and mortality data estimates.

All but one Sensor Fish experienced a significant event, as determined from acceleration magnitude data ( $<1 \%$; $N=109$ ). Event severity was greatest for Sensor Fish passing through Spillbay 3 at the 3.5-ft gate opening, with a mean value of $175.03 \mathrm{~g}(\mathrm{~N}=7)$ for the most severe event per release and $131.34 \mathrm{~g}$ for multiple events for that condition.

The majority of Sensor Fish significant events were classified as collisions; the most severe occurred on the spillway chute. Shear events were infrequent, occurring at all sub-regions of the passage route, but frequency of occurrence was greatest during passage through the 3.5-ft gate opening.

Flow quality as computed using the Sensor Fish turbulence index was best for passage through Spillbay 3, 1.5-ft gate opening. The most inferior flow quality was observed for flow through Spillbay 3 at the 3.5 -ft gate opening.

Depth of flow and the resulting distance from spillway structure has been determined to be a factor in the frequency of occurrence, location of occurrence, and severity of potentially injurious exposures. Comparison of the frequency of occurrence of collisions on the spillway chute for the 1.5-ft tainter gate opening with that at the 3.5 -ft gate opening supports this assumption.

Analysis of Sensor Fish significant event severity information and turbulence index values indicates that passage through Spillway 3 at the 3.5-ft gate opening at Detroit Dam is the most detrimental to fish passage. This conclusion was supported also by HI-Z-tagged live fish results in which close to $62 \%$ of the fish were injured. Although the other spillbay and flow conditions were not as severe, both Sensor Fish magnitudes and live fish malady rates at Detroit Dam were the highest realized from all jointly conducted Sensor Fish/HI-Z-tagged fish testing efforts to date. 


\section{Acronyms and Abbreviations}

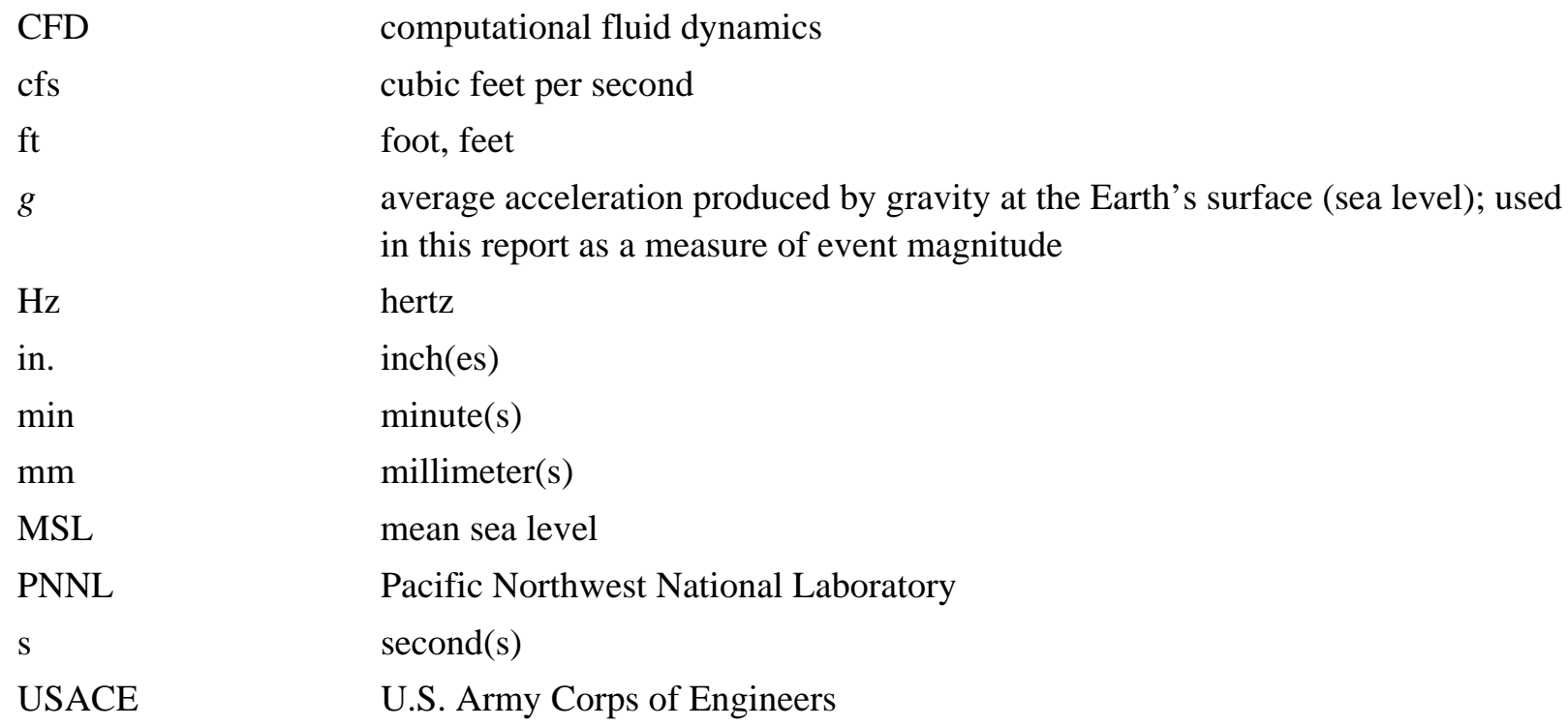




\section{Contents}

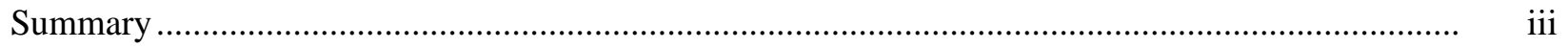

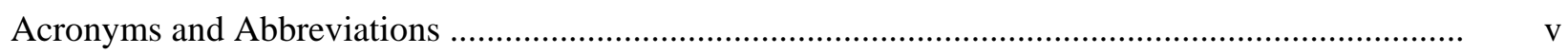

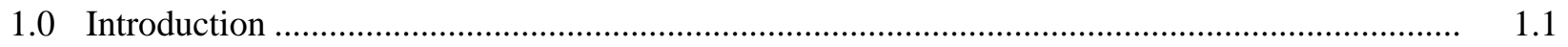

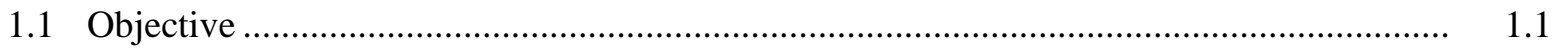

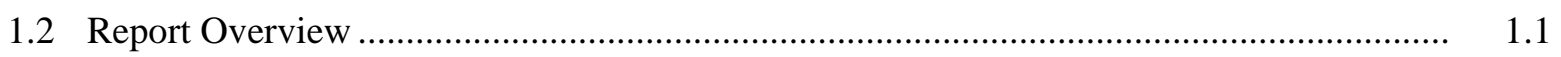

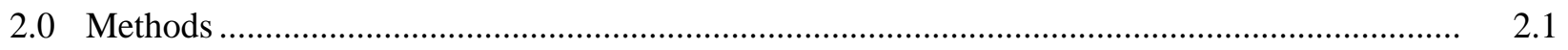

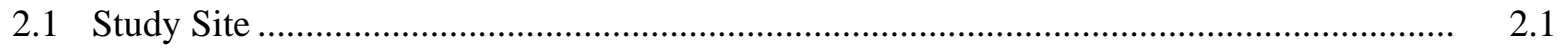

2.2 Sensor Fish Device................................................................................... 2.1

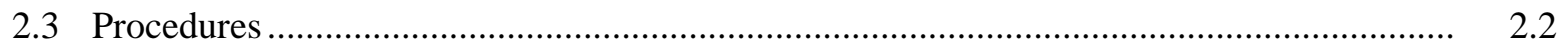

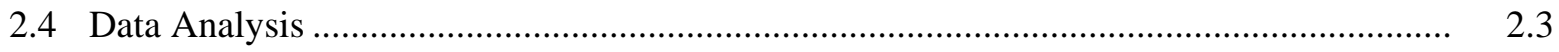

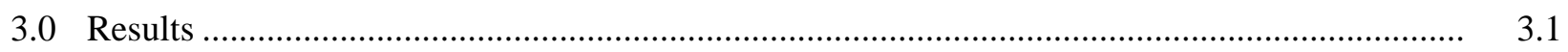

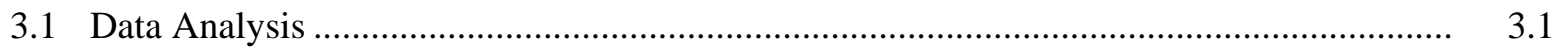

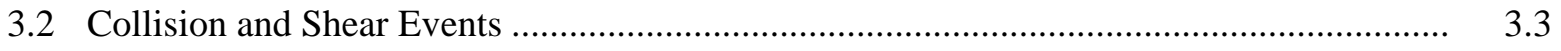

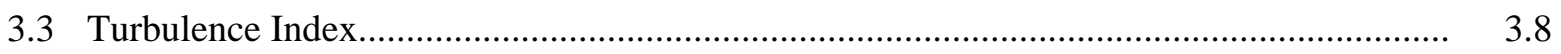

3.4 Comparison of Sensor Fish and Live-Fish Data .......................................................... 3.8

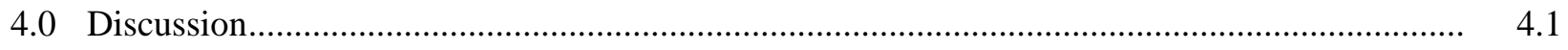

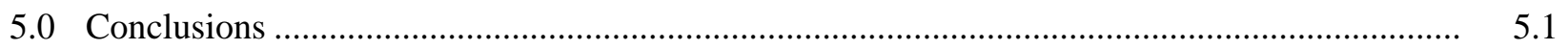

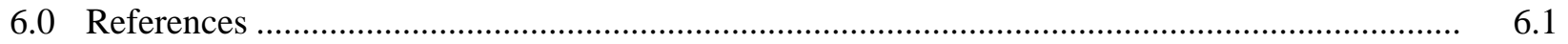

Appendix A - Field Log Data Sheets …................................................................................... A.1

Appendix B - Data Summary Tables for Each Sensor Fish Release .............................................. B. B

Appendix C - Pressure and Acceleration Time Histories of Each Sensor Fish Release .................... C. C.1

Appendix D - Pressure and Angular Rate-of-Change Time Histories of Each Sensor

Fish Release ........................................................................................................ D.1 


\section{Figures}

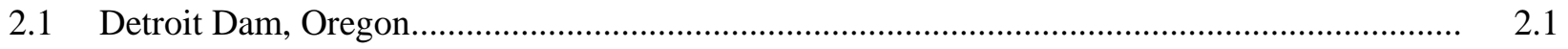

2.2 Six-degree-of-freedom Sensor Fish device .......................................................................... 2.2

3.1 Sensor Fish data overlaid on a cross section of Detroit Dam showing major timing mark approximate locations ....

3.2 Percentage of Sensor Fish releases with zero, one, or more significant events by release location and gate opening

3.3 Location of Sensor Fish significant events by passage region.................................................. 3.5

3.4 Sensor Fish significant event occurrence by type

3.5 Mean, maximum, and minimum peak acceleration magnitudes for the most severe significant event observed per Sensor Fish release by location and gate opening

3.6 Mean, maximum, and minimum acceleration magnitudes for all Sensor Fish significant events by release location and gate opening

3.7 Mean acceleration magnitude for all Sensor Fish significant events by event location.

3.8 Live-fish mortality and malady estimates contrasted with Sensor Fish significant event magnitudes

3.9 Sensor Fish event magnitudes by region

3.10 Relationship between live-fish estimated malady rate and average number of significant events occurring in the stilling basin per release

3.11 Relationship between live-fish estimated malady rate and Sensor Fish turbulence index.

4.1 Spillbay 3 at Detroit Dam showing the rough, irregular concrete surface.

4.2 Spillbay 6 at Detroit Dam showing turbulent flow created on the rough spillway chute

4.3 Flow through Spillbay 3 spreads to adjoining spillbays

4.4 Hydraulic jump occurs as flow passes under the tainter gate .....

4.5 Chips and scratches visible on the polycarbonate Sensor Fish casing

\section{Tables}

3.1 Number of Sensor Fish releases by study treatment

3.2 Sensor Fish releases for each spillbay showing location and type of most severe significant event observed.

3.3 Location and frequency of occurrence of all Sensor Fish significant events by event location and type

3.4 Computed area under the curve for angular rate-of-change and acceleration magnitudes

3.5 Survival and malady-free rates for rainbow trout passed deep at Detroit Dam, July 2009 ..... 


\subsection{Introduction}

Salmonid survival has been impacted by the construction of dams on the North Santiam River in Oregon. Dams have obstructed upstream passage and habitat for spawning and rearing, as well as altered downstream flows and water temperature patterns, contributing to species decline. Temperature requirements are currently being assessed and monitored at Detroit Dam.

Detroit Dam, used primarily for flood control, recreation, municipal and irrigation water, and power production, normally does not spill during salmonid migration periods. A fire in the Detroit Dam powerhouse in 2007 forced spill, resulting in cooler downstream temperatures for fish. Based on the success of spilling following the fire, assessing the option of using spill to regulate water temperature for fish health is being evaluated as part of the Willamette Biological Opinion (NMFS 2008).

This report documents an investigation of spill passage conditions at Detroit Dam in July 2009. The study was conducted by Pacific Northwest National Laboratory (PNNL) for the U.S. Army Corps of Engineers (USACE), Portland District, and performed concurrently with HI-Z-tag studies of passage survival for rainbow trout conducted by Normandeau Associates, Inc.

This study will contribute to decisions as to whether spill is an alternative in optimizing downstream temperatures for improved fish survival.

\subsection{Objective}

The objective of this study was to describe and compare passage exposure conditions through Spillbay 3 and Spillbay 6 at two spillgate openings at Detroit Dam, identifying regions that may potentially cause fish injury or mortality. Sensor Fish devices were used to collect data on the exposure conditions.

\subsection{Report Overview}

Chapter 2 describes the methods, including the study site and the Sensor Fish device. Chapter 3 presents the results of the study, followed by a discussion in Chapter 4. Conclusions are offered in Chapter 5, followed by Chapter 6, the sources cited in this report. Appendix A contains field log data that provides dam operating conditions, release elevations, and deployment and recovery times for each Sensor Fish release. Appendix B provides summary data tables for each Sensor Fish release. Dam operating conditions, exposure event descriptions, pressure at injection, and rates of change in pressure are included in the tables. Appendix $\mathrm{C}$ consists of graphs of pressure and acceleration time histories of each Sensor Fish release. Angular rate-of-change vector magnitude time histories of each Sensor Fish release are presented in Appendix D. 


\subsection{Methods}

\subsection{Study Site}

Detroit Dam, located on the North Santiam River in Marion County, Oregon, is a storage dam used for flood control, power generation, irrigation, navigation, and recreation (Figure 2.1). The dam has two powerhouse units with a hydraulic capacity of $5340 \mathrm{ft}^{3} / \mathrm{sec}$ and a gated spillway with six spillbays. The dam is approximately $463 \mathrm{ft}$ tall and $1580 \mathrm{ft}$ long. Only Spillbay 6 has guidewalls, which limits spillflow interaction with the adjacent spillbay. The spillway crest is located at $1541 \mathrm{ft}$ mean sea level (MSL). The stilling basin contains dentates, and floor elevation is approximately $1170 \mathrm{ft}$ MSL.

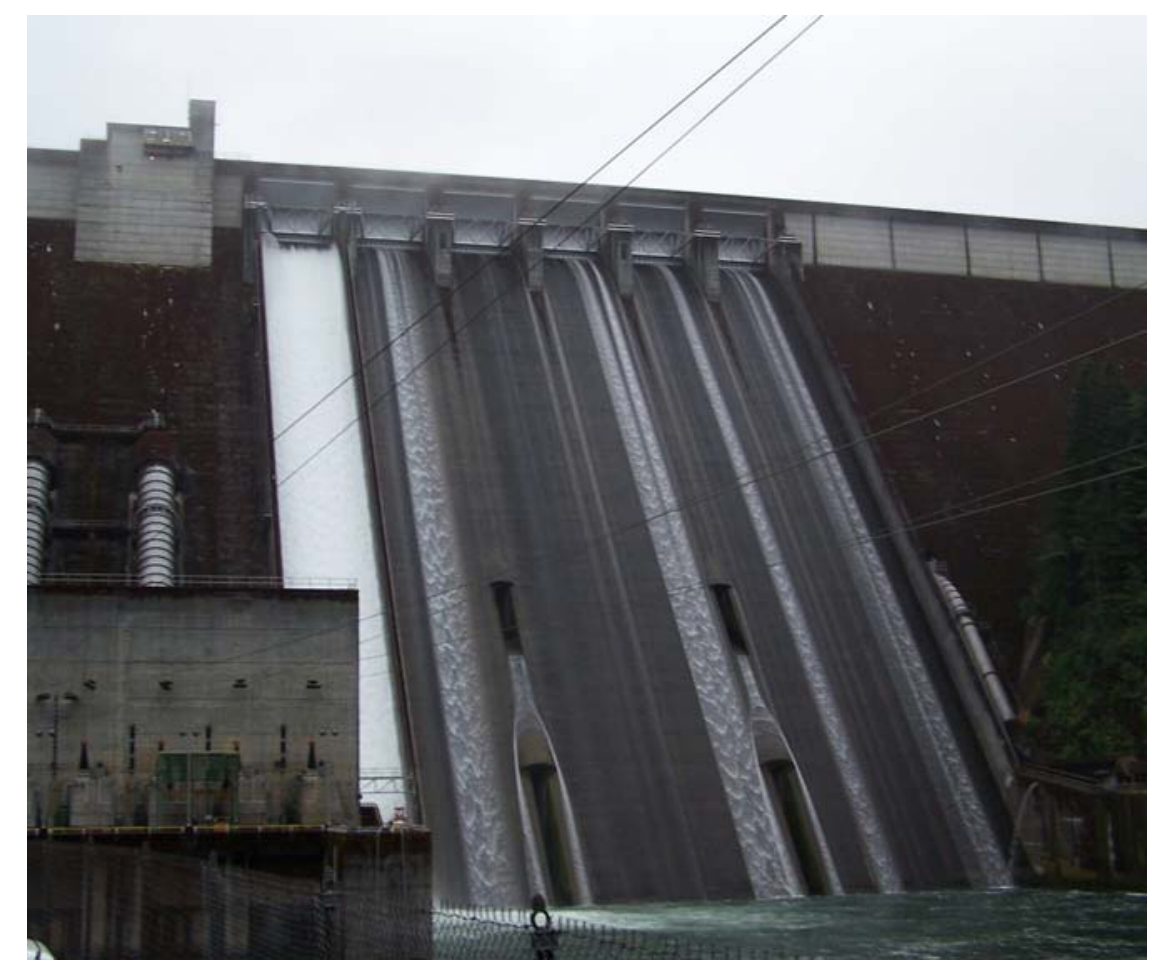

Figure 2.1. Detroit Dam, Oregon.

\subsection{Sensor Fish Device}

The Sensor Fish housing is constructed of clear polycarbonate plastic (Figure 2.2). It is $24.5 \mathrm{~mm}$ in diameter and $90 \mathrm{~mm}$ long and weighs 43 grams. The Sensor Fish is nearly neutrally buoyant in fresh water. The Sensor Fish measures the three components of linear acceleration, the three components of angular velocity (these together comprise the six degrees of freedom), absolute pressure, and temperature, at a sampling frequency of 2,000 $\mathrm{Hz}$ per sensor channel over a recording time of about $4 \mathrm{~min}$.

The Sensor Fish consists of modules that charge its internal battery, program the sensor settings, acquire data, and convert from analog signal to digital form. The acquired data are stored in an internal memory card and transferred to computers via a wireless infrared link using an external infrared link 
modem. Sensor Fish are deployed, acquiring data in response to hydraulic conditions and interaction with structure; units are retrieved; and the data are downloaded, analyzed, and interpreted.

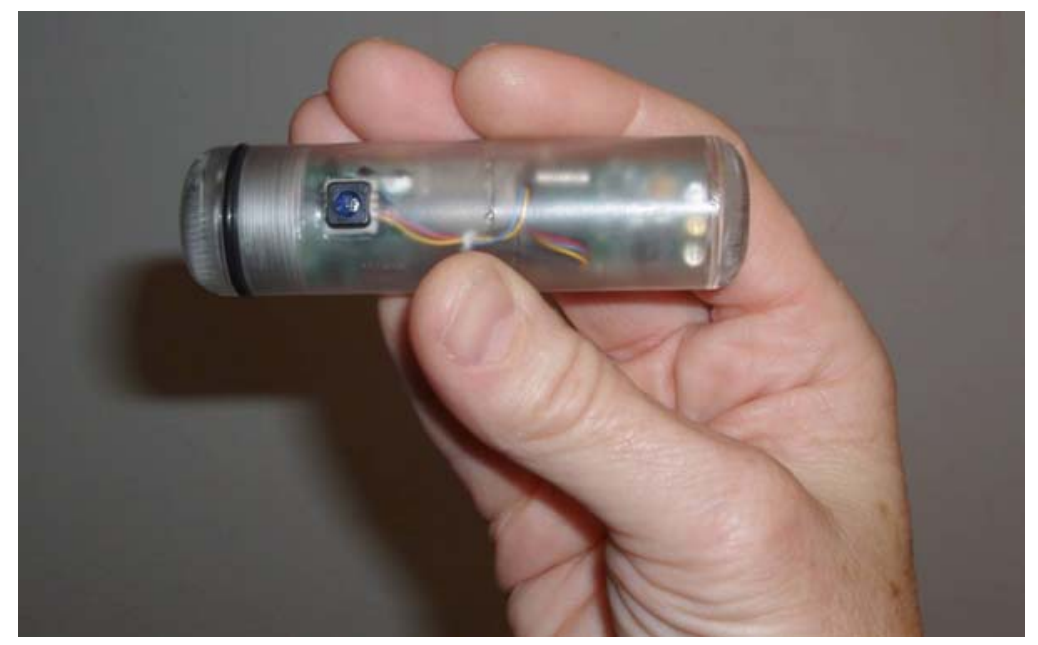

Figure 2.2. Six-degree-of-freedom Sensor Fish device.

Retrieval of the Sensor Fish is aided by the attachment of a micro-radio transmitter (Advanced Telemetry Systems, Isanti, Minnesota) and HI-Z balloon tags (Normandeau Associates, Inc., Bedford, New Hampshire), which are identical to those used for live test fish (Heisey et al. 1992). HI-Z tags contain a water-soluble capsule filled with a chemical that produces gas when activated with water, a process that takes approximately 3 min following initiation. The balloons inflate sufficiently to bring the Sensor Fish to the surface for recovery, and a directional radio receiver antenna used by boaters in the tailrace homes in on the radio transmitter attached to the Sensor Fish.

\subsection{Procedures}

Sensor Fish releases were made at Detroit Dam through Spillbay 3 and Spillbay 6. Releases were made through induction systems installed in each spillbay. The induction systems consisted of largediameter (4-in.) stainless steel pipes with flexible hose attachments, installed approximately mid-bay. The piping extended vertically from the spill deck into the water in the forebay immediately upstream of the test spillbay. Flexible hosing (4-in.-diameter) connected the terminus of the steel pipe to the juncture of the modified head tanks where live fish and Sensor Fish were introduced into the injection systems. Control releases were made through an equivalent induction system located downstream of Spillbay 6, using a 4-in. flexible pipe extending into the tailrace.

A computational fluid dynamics (CFD) model was used to simulate spillway approach flows to the spillbays with gate openings of $1.5 \mathrm{ft}$ and $3.5 \mathrm{ft}$. The simulated flow field identified elevations for introduction of live fish and Sensor Fish so that they would enter the spillbay at approach flow velocities of approximately $5 \mathrm{ft} / \mathrm{sec}$. Spillway discharge was based on gate opening, with a 1.5 -ft opening yielding approximately $1560 \mathrm{cfs}$ flow and a 3.5-ft opening yielding approximately $3010 \mathrm{cfs}$ flow. The pipe terminus for the higher flow (3.5-ft gate opening) was positioned directly over the spillway crest at approximately $1544 \mathrm{ft}$ MSL; the pipe for the lower flow (1.5-ft gate opening) extended approximately $4 \mathrm{ft}$ past the spillway crest, with the terminus located at approximately $1542.5 \mathrm{ft}$ MSL. Both pipes were 
positioned approximately $3 \mathrm{ft}$ above structural surfaces. Control releases were conducted at both 1.5- and 3.5-ft spillgate openings discharging through Spillway 6.

Sensor Fish releases were interspersed with releases of HI-Z-tagged live fish through the same release pipes in a concurrent study conducted by Normandeau Associates, Inc. The study plan called for one Sensor Fish release for every 10 live-fish treatment releases, when feasible. Due to the uncertainty of Sensor Fish resilience following passage over Detroit Dam spillbays, the study plan requested coordination with USACE for continuance following the loss or damage of four Sensor Fish. Allowable Sensor Fish losses were extended to 10 units before work was terminated.

\subsection{Data Analysis}

Sensor Fish data sets consist of time histories that include angular motion (pitch, roll, and yaw) as well as the measurements of pressure, acceleration ( $x, y$, and $z$ axes), temperature, and battery status extending from the time of release through the period of data acquisition programmed prior to release of the Sensor Fish (Deng et al. 2007). Data time histories contain a data point for each transducer every $0.0005 \mathrm{~s}$. This time interval between digital samples corresponds to a 2,000-Hz sampling rate for each of the analog outputs from Sensor Fish acceleration, rotation, and pressure sensors. Sampling of all analog data streams occurs nearly simultaneously within each sampling interval.

Water depth in feet is estimated, when appropriate, from absolute pressure at various points along each Sensor Fish route by subtracting atmospheric pressure, determined at the time of the release of each Sensor Fish, and dividing the resulting gage pressure by 0.4335 , the pressure in pounds per square inch of $12 \mathrm{in}$. of fresh (distilled) water at $39.2^{\circ} \mathrm{F}\left(4^{\circ} \mathrm{C}\right)$. The raw output of the triaxial accelerometers is processed to detect and quantify Sensor Fish response to turbulence, contact with structure (collision), and shear. Acceleration vector magnitude is computed each sampling interval using triaxial accelerometer output and is one of the variables analyzed and reported to characterize passage conditions and the occurrence of collision and shear events. Triaxial angle rate-of-change data are processed similarly to triaxial acceleration data to provide further information about the response of the Sensor Fish to flow conditions and another measure of quality of flow.

Analysis of the raw data from the Sensor Fish begins with preparation of plots showing absolute pressure, triaxial acceleration, and triaxial rotation. These records are visually inspected to identify prospective collision and shear events and to obtain a general overview of the passage conditions present for each test treatment. Changes in pressure during passage include features that are consistently present that result from the design of passageway structures and the dynamics of water flow through the passageway. These features in the pressure time history permit acceleration and rotation data to be divided into segments corresponding to specific locations (zones) that extend from Sensor Fish injection to exit from the stilling basin. Each region is identified by characteristic features in the Sensor Fish pressure time history and characteristics in triaxial acceleration and rotation data. For each Sensor Fish data set, events of interest, such as rapid pressure changes, collisions, shear, and severe turbulence, are identified and quantified. Quantification of events includes the time of occurrence, location by zone, and extraction of information describing severity as well as additional information to separate collisions from shear exposure. 


\subsection{Results}

A total of 109 Sensor Fish were released at Detroit Dam between July 13 and July 21, 2009, with 91 data sets acquired (Table 3.1). A successful release requires both the recovery of the unit and successful download of acquired data. All Sensor Fish were recovered successfully. However, 18 data sets were unable to be downloaded due to damage during passage. Pipe termini elevations were confirmed to be approximately $1544 \mathrm{ft}$ MSL and $1542.5 \mathrm{ft}$ MSL for the 3.5-ft and 1.5-ft gate openings, respectively.

Table 3.1. Number of Sensor Fish releases by study treatment.

\begin{tabular}{|c|c|c|c|c|c|c|c|c|}
\hline Spillbay & $\begin{array}{c}\text { Gate } \\
\text { Opening } \\
(\mathrm{ft})\end{array}$ & $\begin{array}{c}\text { Mean } \\
\text { Forebay } \\
\text { Elevation } \\
(\mathrm{ft} \text { MSL) }\end{array}$ & $\begin{array}{l}\text { Mean } \\
\text { Tailwater } \\
\text { Elevation } \\
\text { (ft MSL) }\end{array}$ & $\begin{array}{c}\text { Mean } \\
\text { Spillbay } \\
\text { Q (cfs) }\end{array}$ & $\begin{array}{c}\text { Mean Total } \\
\text { Project } \\
\text { Flow (cfs) }\end{array}$ & $\begin{array}{c}\text { Total } \\
\text { Number } \\
\text { Released }\end{array}$ & $\begin{array}{l}\text { Number of } \\
\text { Sensors } \\
\text { Damaged/ } \\
\text { Unusable }^{(a)}\end{array}$ & $\begin{array}{c}\text { Number of } \\
\text { Usable } \\
\text { Data Sets }\end{array}$ \\
\hline 3 & 1.5 & 1560.5 & 1200.7 & 1549.0 & 2455.3 & 30 & 6 & 24 \\
\hline 3 & 3.5 & 1559.5 & 1201.4 & 2915.1 & 3375.1 & 10 & 3 & 7 \\
\hline 6 & 1.5 & 1559.3 & 1200.8 & 1559.4 & 1558.9 & 18 & 1 & 17 \\
\hline 6 & 3.5 & 1560.5 & 1200.7 & 3008.0 & 3385.1 & 32 & 6 & 26 \\
\hline Control & 1.5 & 1560.2 & 1201.1 & 1548.4 & 2204.4 & 10 & 1 & 9 \\
\hline \multirow[t]{2}{*}{ Control } & 3.5 & 1560.3 & 1200.7 & 2997.6 & 3488.1 & 9 & 1 & 8 \\
\hline & & & & & Total & 109 & 18 & 91 \\
\hline
\end{tabular}

(a) Some Sensor Fish units were reused after attempted repairs.

Detailed data on which this chapter is based are provided in the appendices. Appendix A contains study data that include the release and recovery times for each Sensor Fish, spillway flow condition, and other project information for the study period. Appendix B contains tables of observed maximum acceleration magnitudes, pressure rates of change, and computed release elevations for all Sensor Fish releases as well as dam operations data. Graphs with plots of pressure and acceleration magnitude are located in Appendix C. The angular rate-of-change magnitude for each Sensor Fish release is graphed in Appendix D.

\subsection{Data Analysis}

Sensor Fish data analysis included computing absolute and gage pressure, acceleration magnitudes, and rotational magnitudes, and reviewing their time histories. Collision and/or shear events appear as high-amplitude impulses in acceleration magnitude. To qualify as a significant event, a high-amplitude acceleration impulse must have a peak value equal to or greater than $95 \mathrm{~g}$. Significant events frequently also show concurrent high-amplitude pressure and rotation magnitude values, which aid in identifying the location of the event in time and space and in distinguishing collisions and strike events from shear events. 
The location of a significant event is determined by the location of the impulse relative to distinctive, consistent features observed in the pressure time histories. Timing marks used to locate significant events and identify regions of passage include

1. passage through the tainter gate opening

2. impact of discharge jets on the spillway chutes and redirection of the spillway jet

3. passage along the spillway chute

4. plunge into the stilling basin

5. passage to the tailrace surface.

Examples of pressure timing marks used for this study are shown in Figure 3.1. A large drop in pressure (shown by the blue line) occurs as the Sensor Fish passes under the tainter gate; a comparatively flat pressure (atmospheric) is evident during passage down the spillway chute.

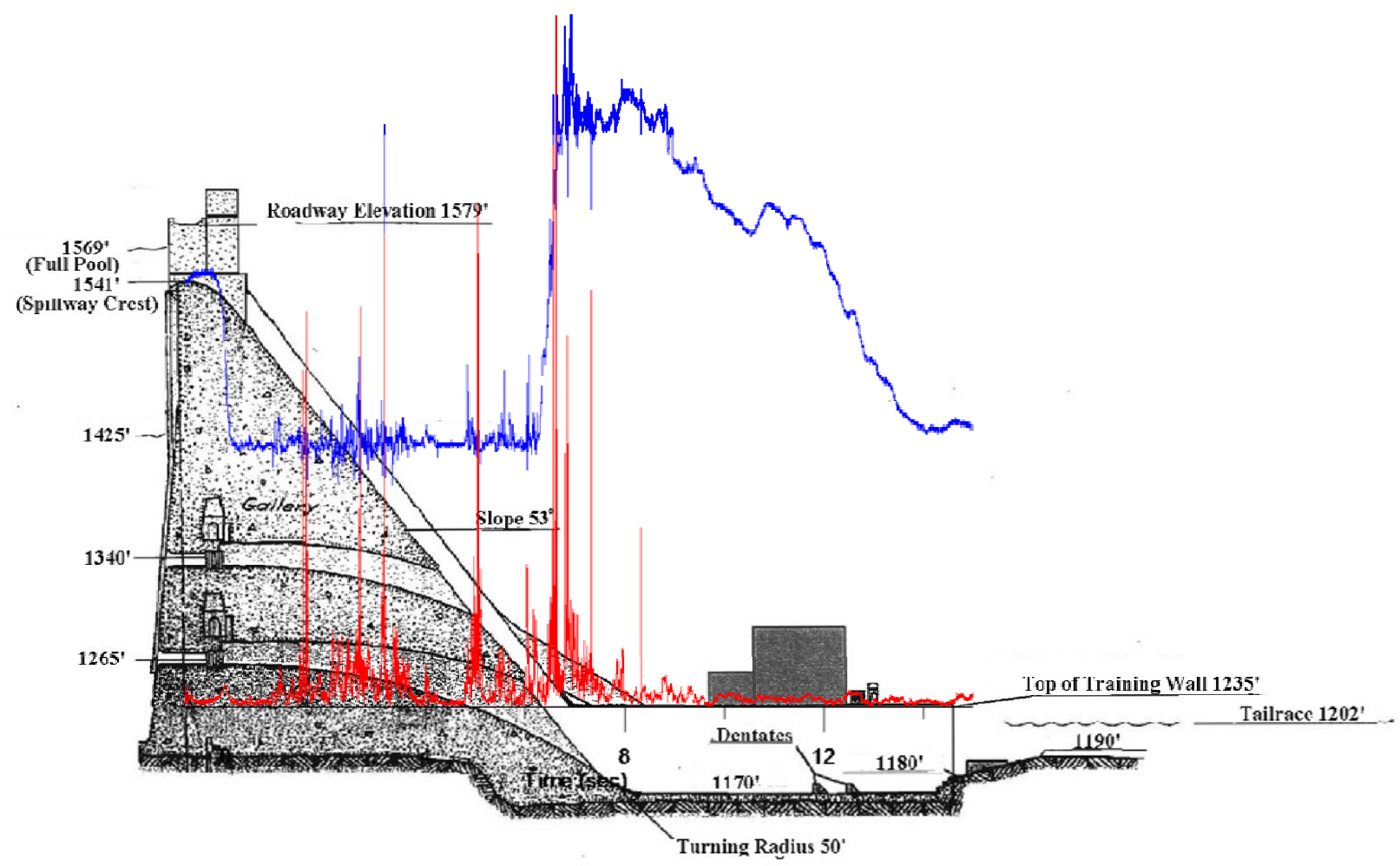

Figure 3.1. Sensor Fish data overlaid on a cross section of Detroit Dam showing major timing mark approximate locations. The blue line is pressure; the red line is acceleration vector magnitude in $g$.

Pressure again rises as the Sensor Fish plunges into the stilling basin before decreasing as the sensor comes to the surface in the tailrace. Due to the angle (53 degrees) of the spillway, some Sensor Fish were projected through the tainter gate opening near-horizontal to the spillway chute due to back pressure, meeting the concrete at different positions, dependent on depth of passage and trajectory angle, before continuing down the slope. Angular rate-of-change and acceleration magnitude data sets support this 
finding. In most cases, the discharge jet carried the Sensor Fish without the units experiencing a significant collision event at the point of flow impact on the concrete chute. However, Sensor Fish were more likely to have a significant collision event nearer the impact zone following passage through the 3.5-ft gate opening.

A total of $87.5 \%$ (21 of 24) of the Sensor Fish passing through the 1.5-ft gate opening at Spillbay 3 and $88.2 \%$ (15 of 17) of those passing through Spillbay 6 at the equivalent gate setting exhibited evidence of late flow jet contact with the spillway chute. Impact occurred at 1.18 and $1.21 \mathrm{~s}$ (mean value for each 1.5-ft gate opening treatment) following passage under the Spillbay 3 and Spillbay 6 tainter gates, respectively. At the 3.5-ft gate opening, spillway contact occurred at 0.72 and $1.07 \mathrm{~s}$ following tainter gate passage for Spillbay 3 and Spillbay 6, respectively, with 100\% of the former and $96 \%$ (25 of 26) of the latter impacting the chute.

\subsection{Collision and Shear Events}

A total of $98.6 \%$ of the Sensor Fish experienced at least one significant event during spillway passage. We define a significant event as an impulse in acceleration magnitude greater than or equal to $95 \mathrm{~g}$. The event could be caused by collision on spillway structure or exposure to shear. Greater than 93\% of the Sensor Fish experienced more than one significant event during passage through the spillbays. No significant events were observed during control passage into the tailrace.

Table 3.2 shows the number of analyzed Sensor Fish by release location and type of the most severe significant event. The most severe events were observed primarily as collisions on the spillway chute. Sensor Fish passing through the 1.5-ft gate opening, with an estimated flow of $1560 \mathrm{cfs}$, had over $90 \%$ of the most severe events as collisions on the spillway chute; the 3.5-ft gate opening, with an estimated flow of $3090 \mathrm{cfs}$, had more than $70 \%$ of the most severe events as collisions on the chute. The most severe event per Sensor Fish release was rarely shear, as only three of the most severe events were of this type. However, all occurred following passage through Spillbay 6 at the 3.5-ft gate opening.

Table 3.3 summarizes the total number of significant collision and shear events by significant event type and location. Multiple events occurred most frequently for Sensor Fish passing through the 1.5-ft gate opening of Spillbay 6, with an average of 5.71 events per Sensor Fish release. The fewest events per release (4.88) occurred through Spillbay 3 at the same gate opening. Multiple events per Sensor Fish release are shown in Figure 3.2.

Significant events were most frequent on the spillway chute regardless of spillbay or gate opening, followed by the stilling basin/tailrace region (Figure 3.3). There were no events at the plunge into the stilling basin for Sensor Fish passing through Spillbay 3 at the 1.5-ft gate opening and only a few events at the other treatments. The percentage of events in the stilling basin/tailrace region was slightly higher for the Sensor Fish passing through Spillbay 3 at the 3-ft gate opening, followed by Spillbay 6 at the same gate opening and Spillbay 3 at the 1.5-ft opening.

Collision or shear significant event frequency of occurrence varied slightly with gate opening. Sensor Fish were more likely to experience shear when passing through the 3.5-ft gate opening (Figure 3.4). However, the frequency of collisions on the spillway chute was greater than $90 \%$, regardless of flow or release location. 
Table 3.2. Sensor Fish releases for each spillbay showing location and type of most severe significant event observed.

\begin{tabular}{|c|c|c|c|c|c|c|c|c|c|c|c|c|}
\hline \multirow[b]{2}{*}{$\begin{array}{l}\text { Release } \\
\text { Location }\end{array}$} & \multirow[b]{2}{*}{$\begin{array}{c}\text { Gate } \\
\text { Opening }\end{array}$} & \multirow[b]{2}{*}{$\begin{array}{l}\text { Number } \\
\text { of } \\
\text { Releases }\end{array}$} & \multirow{2}{*}{$\begin{array}{c}\text { Number of } \\
\text { Sensor Fish } \\
\text { Having at } \\
\text { Least } 1 \text { Event } \\
|\mathrm{a}|>95 \mathrm{~g}\end{array}$} & \multicolumn{3}{|c|}{$\begin{array}{l}\text { Frequency of Occurrence of the } \\
\text { Most Severe Collision Events by } \\
\text { Location }\end{array}$} & \multicolumn{3}{|c|}{$\begin{array}{l}\text { Frequency of Occurrence of the } \\
\text { Most Severe Shear Events by } \\
\text { Location }\end{array}$} & \multicolumn{3}{|c|}{$\begin{array}{l}\text { Frequency of Occurrence of the } \\
\text { Most Severe Events by Location }\end{array}$} \\
\hline & & & & $\begin{array}{l}\text { On } \\
\text { Chute }\end{array}$ & $\begin{array}{l}\text { At } \\
\text { Plunge }\end{array}$ & $\begin{array}{l}\text { In Stilling } \\
\text { Basin/ } \\
\text { Tailrace }\end{array}$ & $\begin{array}{c}\text { On } \\
\text { Chute }\end{array}$ & $\begin{array}{l}\text { At } \\
\text { Plunge }\end{array}$ & $\begin{array}{l}\text { In Stilling } \\
\text { Basin/ } \\
\text { Tailrace }\end{array}$ & $\begin{array}{c}\text { On } \\
\text { Chute }\end{array}$ & $\begin{array}{l}\text { At } \\
\text { Plunge }\end{array}$ & $\begin{array}{l}\text { In Stilling } \\
\text { Basin/ } \\
\text { Tailrace }\end{array}$ \\
\hline Spillbay 3 & $1.5 \mathrm{ft}$ & 24 & 24 & 0.92 & 0 & 0.08 & 0 & 0 & 0 & 0.92 & 0 & 0.08 \\
\hline Spillbay 6 & $3.5 \mathrm{ft}$ & 26 & 25 & 0.72 & 0 & 0.16 & 0.08 & 0 & 0.04 & 0.80 & 0 & 0.20 \\
\hline Spillbay 3 & $3.5 \mathrm{ft}$ & 7 & 7 & 0.71 & 0 & 0.29 & 0 & 0 & 0 & 0.71 & 0 & 0.29 \\
\hline Spillbay 6 & $1.5 \mathrm{ft}$ & 17 & 17 & 0.94 & 0 & 0.06 & 0 & 0 & 0 & 0.94 & 0 & 0.06 \\
\hline
\end{tabular}

Table 3.3. Location and frequency of occurrence of all Sensor Fish significant events by event location and type.

\begin{tabular}{|c|c|c|c|c|c|c|c|c|c|c|c|c|}
\hline & \multirow{3}{*}{$\begin{array}{c}\text { Number } \\
\text { of } \\
\text { Releases }\end{array}$} & \multirow{3}{*}{$\begin{array}{c}\text { No } \\
\text { Event }\end{array}$} & \multirow{3}{*}{$\begin{array}{l}\text { Single } \\
\text { Event }\end{array}$} & \multirow[b]{3}{*}{$>1$ Event } & \multirow{3}{*}{$\begin{array}{c}\text { Total } \\
\text { Number } \\
\text { of Events }\end{array}$} & \multirow{3}{*}{$\begin{array}{c}\text { Average } \\
\text { Number } \\
\text { Events per } \\
\text { Condition }\end{array}$} & \multicolumn{6}{|c|}{ Event Location and Type } \\
\hline & & & & & & & \multicolumn{2}{|c|}{ On Chute } & \multicolumn{2}{|c|}{ At Plunge } & \multicolumn{2}{|c|}{$\begin{array}{c}\text { In Stilling Basin/ } \\
\text { Tailrace } \\
\end{array}$} \\
\hline & & & & & & & Collision & Shear & Collision & Shear & Collision & Shear \\
\hline $\begin{array}{l}\text { Spillbay } 3 \text {, } \\
\text { 1.5-ft opening }\end{array}$ & 24 & 0 & 3 & 21 & 117 & 4.88 & 0.82 & 0.00 & 0.00 & 0.00 & 0.16 & 0.02 \\
\hline $\begin{array}{l}\text { Spillbay } 6 \text {, } \\
\text { 3.5-ft opening }\end{array}$ & 26 & 1 & 2 & 23 & 132 & 5.28 & 0.74 & 0.02 & 0.01 & 0.01 & 0.18 & 0.05 \\
\hline $\begin{array}{l}\text { Spillbay 3, } \\
\text { 3.5-ft opening }\end{array}$ & 7 & 0 & 0 & 7 & 37 & 5.29 & 0.70 & 0.03 & 0.03 & 0.00 & 0.19 & 0.05 \\
\hline $\begin{array}{l}\text { Spillbay } 6 \text {, } \\
1.5 \text {-ft opening }\end{array}$ & 17 & 0 & 0 & 17 & 97 & 5.71 & 0.81 & 0.00 & 0.03 & 0.00 & 0.14 & 0.01 \\
\hline
\end{tabular}


Spillbay 3, 1.5' Opening $\square$ Spillbay 6, 3.5' Opening $\square$ Spillbay 3, 3.5' Opening $\square$ Spillbay 6, 1.5' Opening

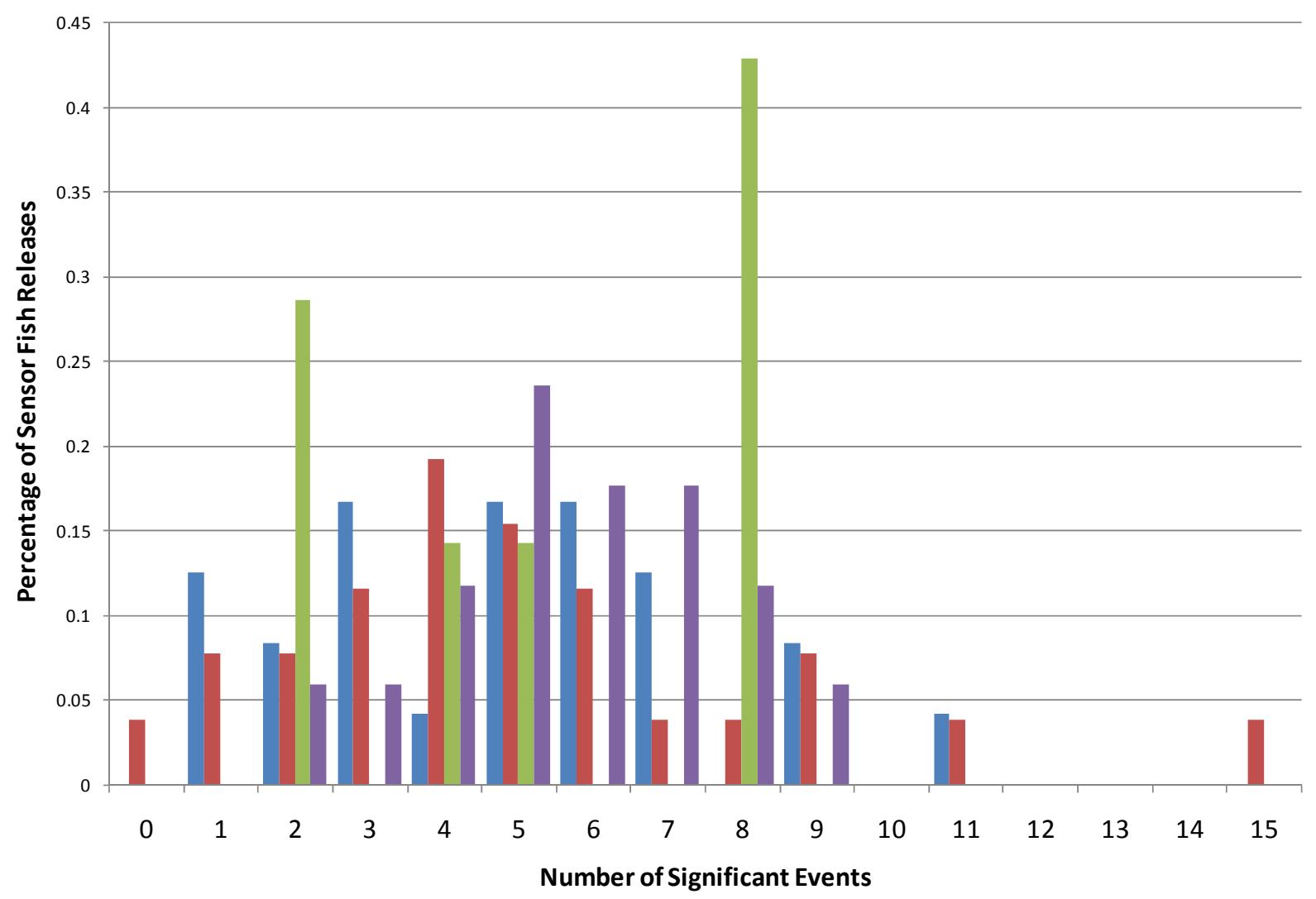

Figure 3.2. Percentage of Sensor Fish releases with zero, one, or more significant events by release location and gate opening.

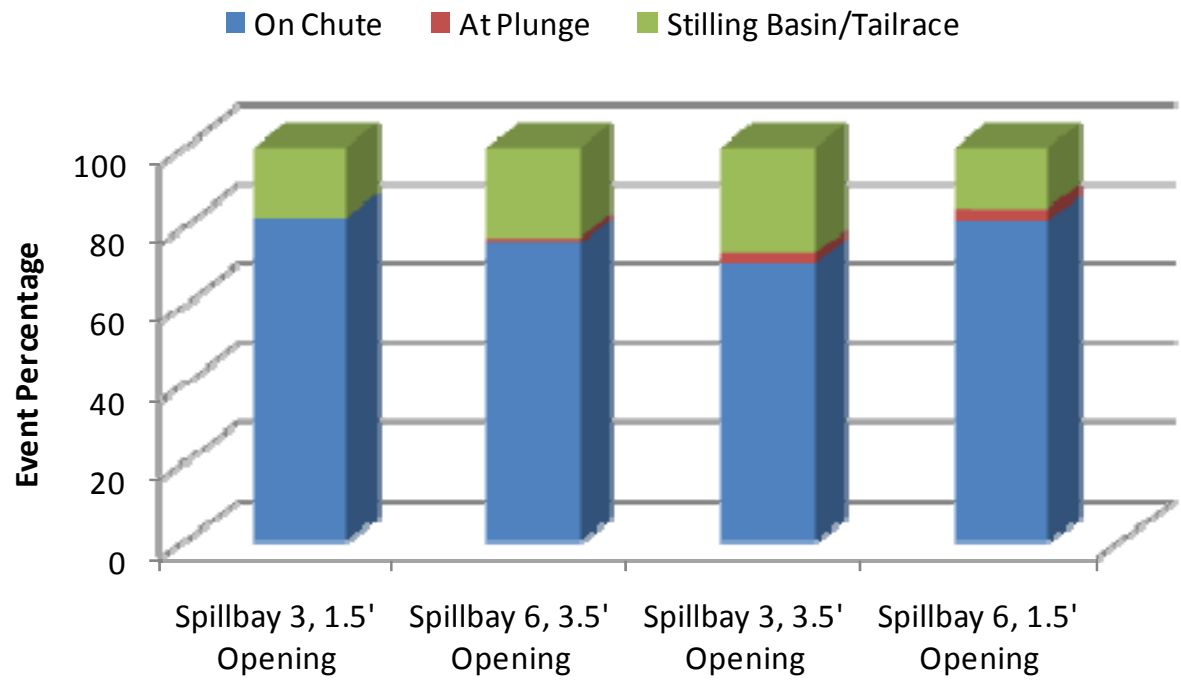

Figure 3.3. Location of Sensor Fish significant events by passage region. 


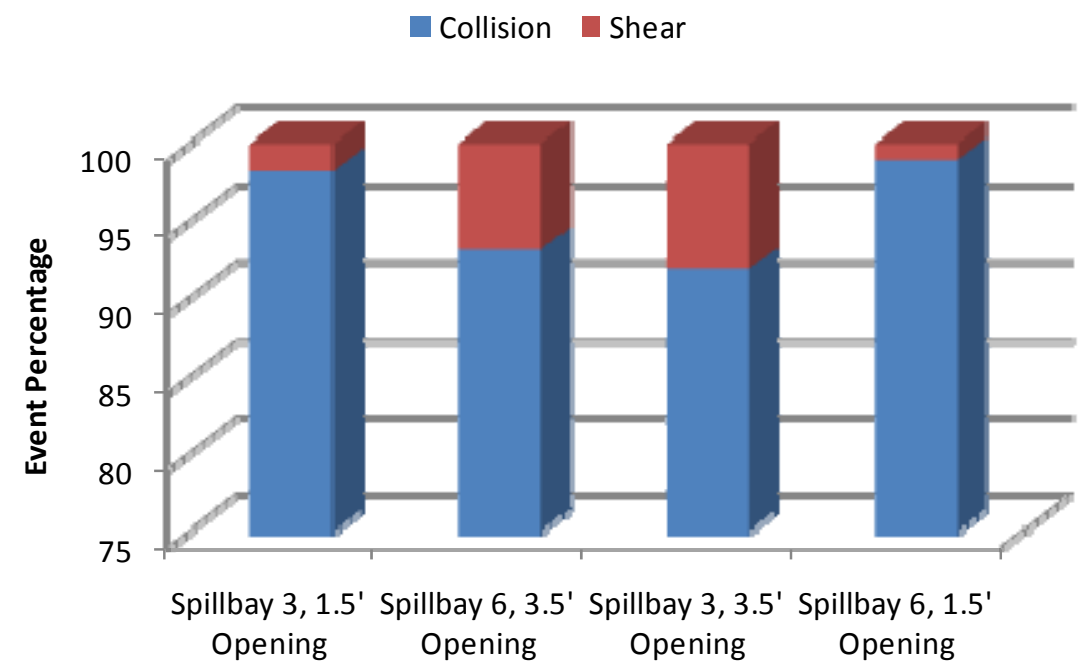

Figure 3.4. Sensor Fish significant event occurrence by type.

The mean, maximum, and minimum acceleration magnitude values for the most severe events are shown in Figure 3.5. Sensor Fish passing through the 3.5-ft gate opening of Spillway 3 had the highest significant event mean magnitude $(175.03 \mathrm{~g})$, and sensors released through the 1.5 - $\mathrm{ft}$ opening of the same spillbay had the lowest mean magnitude $(154.7 \mathrm{~g})$. When this is compared to the total number of severe events per condition, again the highest mean acceleration magnitude was for Sensor Fish passing through the 3.5-ft gate opening of Spillway $3(131.34 \mathrm{~g})$, and the lowest mean magnitude was for passage through the 1.5-ft gate opening of Spillbay 6 (Figure 3.6). However, when the multiple event values are compared, the differences are small.

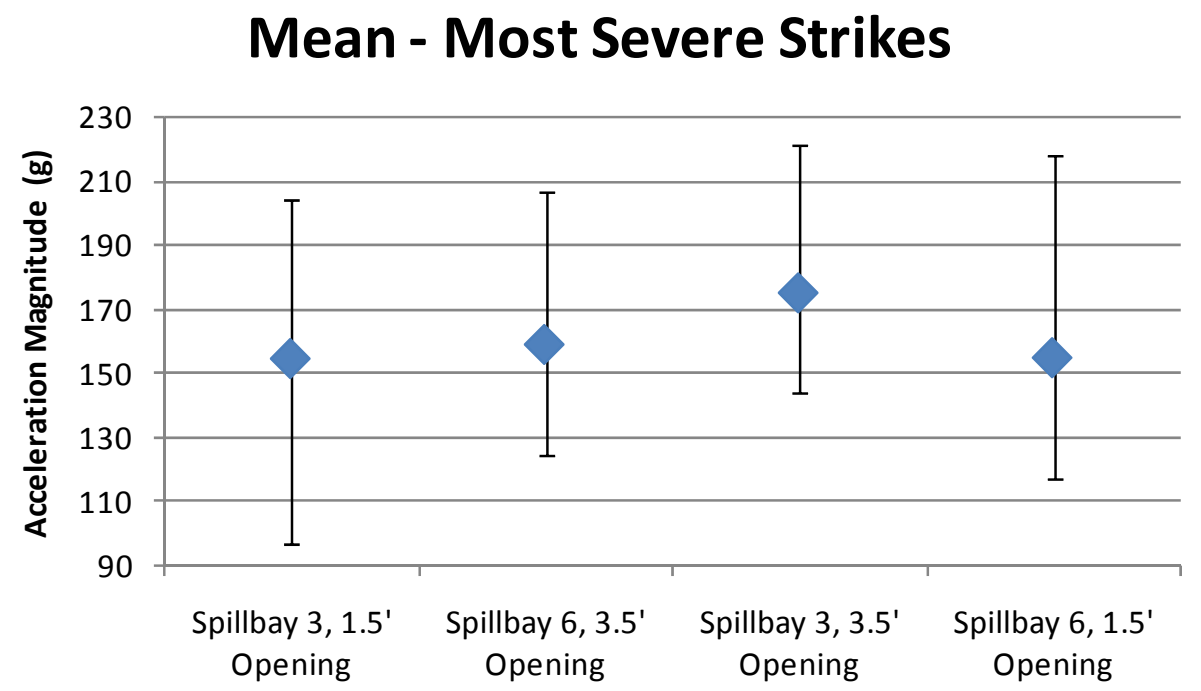

Figure 3.5. Mean, maximum, and minimum peak acceleration magnitudes for the most severe significant event observed per Sensor Fish release by location and gate opening. 


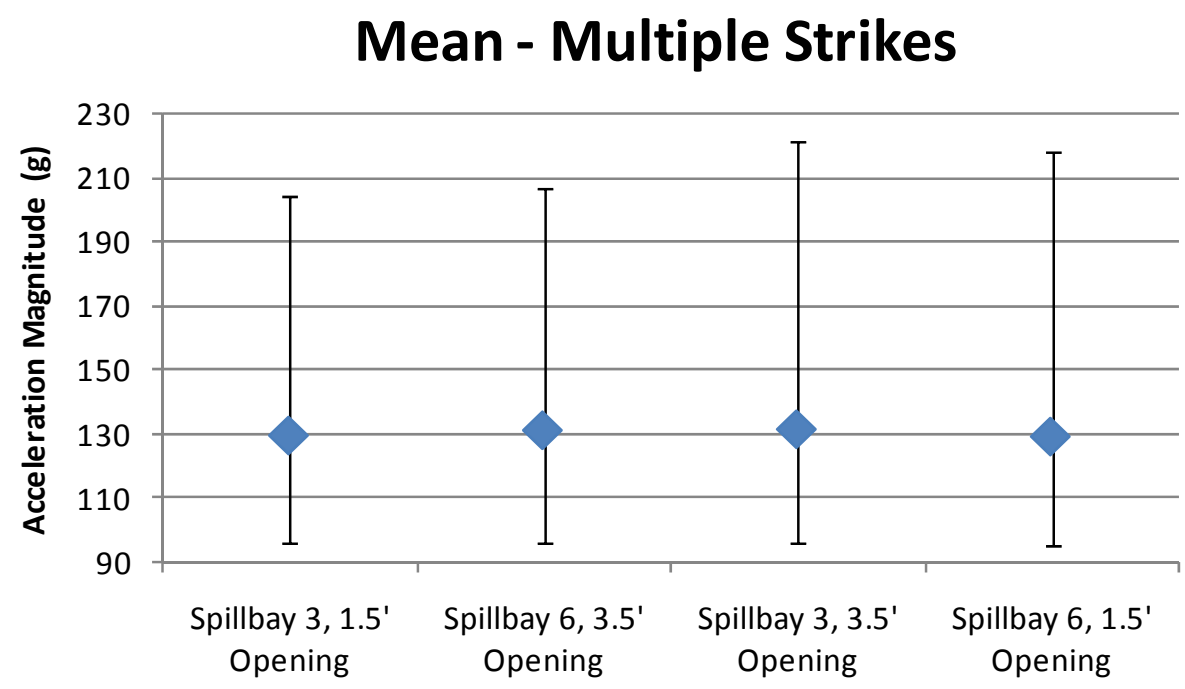

Figure 3.6. Mean, maximum, and minimum acceleration magnitudes for all Sensor Fish significant events by release location and gate opening.

The mean acceleration magnitude values for all Sensor Fish significant events by event location are shown in Figure 3.7. The highest magnitudes occurred in the stilling basin/tailrace region for Spillbay 6 releases, although the magnitudes observed on the spillway chute also were considerable. The chute magnitudes for all releases were virtually equivalent, with slightly higher values for the Spillbay 3, 3.5-ft gate opening releases. The end of the spillway chute where the flow plunges into the stilling basin saw highest values for Spillbay 3, 3.5-ft gate opening releases as well. There were no events in the plunge region for the Spillway 3, 1.5-ft gate opening.

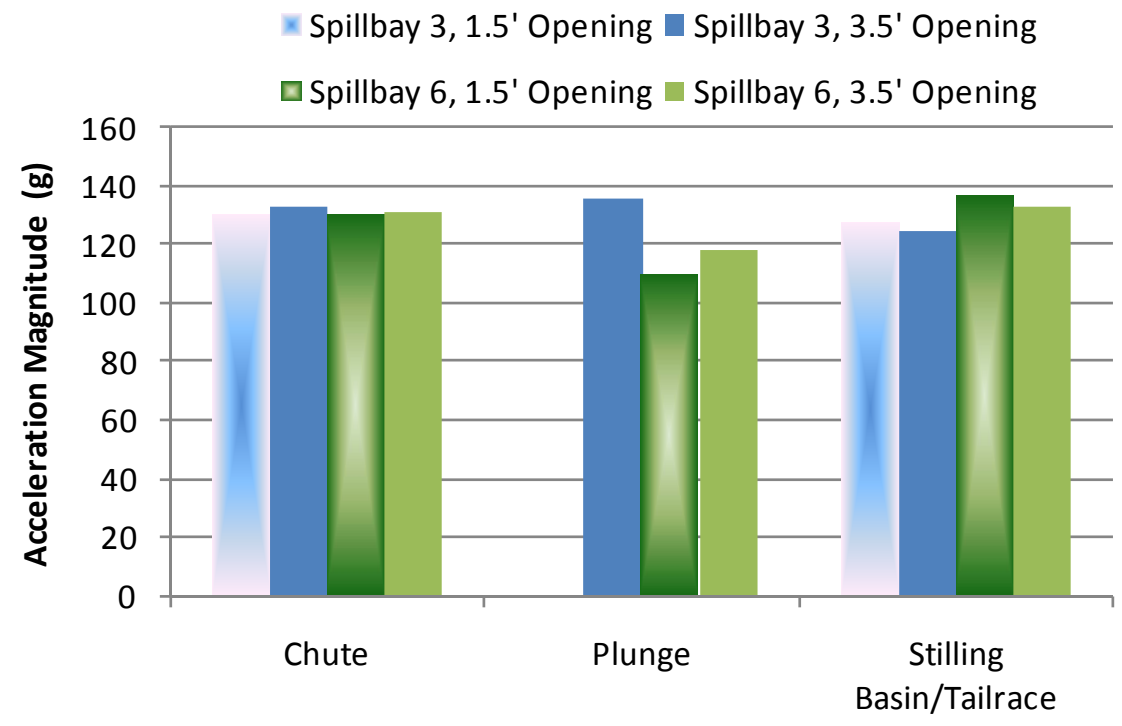

Figure 3.7. Mean acceleration magnitude for all Sensor Fish significant events by event location. 


\subsection{Turbulence Index}

The turbulence index as it is used here is a subjective measure developed by computing the area under the acceleration magnitude and angular rate-of-change magnitude curves for a given time period, in this case the first $15 \mathrm{~s}$ following passage under the tainter gate, with the premise that larger area equates to greater turbulence (Table 3.4). Both the acceleration and angular rate-of-change magnitudes follow similar trends, with area size decreasing in the following sequence: Spillbay 3, 3.5-ft gate opening; Spillbay 6, 3.5-ft gate opening; Spillbay 6, 1.5-ft gate opening; and Spillbay 3, 1.5-ft gate opening.

Table 3.4. Computed area under the curve for angular rate-of-change and acceleration magnitudes.

\begin{tabular}{lccc}
\hline & $\begin{array}{c}\text { Area - Acceleration } \\
\text { Magnitude }\end{array}$ & $\begin{array}{c}\text { Area - Angular Rate-of- } \\
\text { Change Magnitude }\end{array}$ & Combined Area \\
\hline Spillbay 3, 3.5-ft gate opening & 59.74 & 16761.44 & 16821.18 \\
Spillbay 3, 1.5-ft gate opening & 46.12 & 13770.82 & 13816.94 \\
Spillbay 6, 3.5-ft gate opening & 58.93 & 15526.65 & 15585.58 \\
Spillbay 6, 1.5-ft gate opening & 50.10 & 14275.03 & 14325.13 \\
\hline
\end{tabular}

\subsection{Comparison of Sensor Fish and Live-Fish Data}

A live-fish HI-Z-tag study was conducted by Normandeau Associates, Inc. concurrently with the Sensor Fish study at Detroit Dam. Normandeau scientists released approximately 1500 live fish through the same injection systems as the Sensor Fish, under the same test conditions. Sensor Fish releases were interspersed with live-fish releases. Table 3.5 shows the preliminary estimated survival rate and the probability of fish not being injured during passage. ${ }^{1}$

For comparison with Sensor Fish magnitudes, the reciprocal of the malady-free rate is reported as the injury or malady rate; the reciprocal of survival is reported as mortality. Figure 3.8 shows live-fish malady and mortality rates along with the Sensor Fish average significant event magnitudes ( \pm standard error of the mean). Sensor Fish acceleration magnitudes were comparable to the live-fish mortality and malady estimates. Exposure severity varied by spillbay and gate opening (Figure 3.9). For Spillbay 3, 3.5-ft gate opening, and Spillbay 6, 1.5-ft gate opening, the greatest event magnitudes were seen in the stilling basin/tailrace region. Event magnitudes for the spillway chute regions were very similar for all treatments. Greatest event magnitudes for the 3.5-ft gate opening through Spillbay 6 occurred at the plunge region.

Examining the stilling basin/tailrace region more closely, there is a good correlation between live-fish mortality and the average number of events in the stilling basin per release (Figure 3.10).

The live-fish estimated maladies and Sensor Fish turbulence index values also demonstrate a good correlation (Figure 3.11).

\footnotetext{
${ }^{1}$ Email from Paul Heisey, Normandeau Associates, Inc., to Joanne Duncan, PNNL, September 9, 2009.
} 
Table 3.5. Survival and malady-free rates (with 95\% confidence intervals) for rainbow trout passed deep (approximately $3 \mathrm{ft}$ above the spillway crest) at Detroit Dam, July 2009. ${ }^{2}$

\begin{tabular}{|c|c|c|c|c|c|}
\hline \multirow{3}{*}{$\begin{array}{l}\text { Passage Location } \\
\text { Gate opening }\end{array}$} & \multicolumn{2}{|c|}{ Spillbay 6} & \multicolumn{2}{|c|}{ Spillbay 3} & \multirow{3}{*}{$\frac{\text { Contro }}{\text { Pooled }}$} \\
\hline & \multicolumn{2}{|c|}{ Deep } & \multicolumn{2}{|c|}{ Deep } & \\
\hline & $3.5 \mathrm{ft}$ & $1.5 \mathrm{ft}$ & $3.5 \mathrm{ft}$ & $1.5 \mathrm{ft}$ & \\
\hline Number released & 320 & 304 & 298 & 298 & 290 \\
\hline Number recaptured alive & 262 & 274 & 246 & 265 & 287 \\
\hline Number recaptured dead & 53 & 24 & 37 & 29 & 0 \\
\hline Number assigned dead ${ }^{(a)}$ & 5 & 6 & 13 & 4 & 2 \\
\hline Number unknown & 0 & 0 & 2 & 0 & 1 \\
\hline 48-hour survival & $67.4 \%$ & $84.0 \%$ & $63.6 \%$ & $80.6 \%$ & \\
\hline SE & $2.7 \%$ & $2.3 \%$ & $2.9 \%$ & $2.5 \%$ & \\
\hline $95 \%$ CI (+/-) & $5.4 \%$ & $4.5 \%$ & $5.7 \%$ & $4.8 \%$ & \\
\hline Significance & \multicolumn{2}{|c|}{ significant $(P<0.01)$} & \multicolumn{2}{|c|}{ significant $(P<0.01)$} & \\
\hline $\begin{array}{l}\text { Number examined for } \\
\text { maladies }\end{array}$ & 315 & 298 & 283 & 294 & 287 \\
\hline Number without maladies ${ }^{(b)}$ & 149 & 153 & 107 & 161 & 286 \\
\hline Number with maladies & 166 & 145 & 176 & 133 & 1 \\
\hline Malady-free rate & $47.5 \%$ & $51.5 \%$ & $37.9 \%$ & $55.0 \%$ & \\
\hline SE & $2.8 \%$ & $2.9 \%$ & $2.9 \%$ & $2.9 \%$ & \\
\hline $95 \%$ CI (+/-) & $5.5 \%$ & $5.7 \%$ & $5.7 \%$ & $5.7 \%$ & \\
\hline Significance & \multicolumn{2}{|c|}{ non-significant $(P>0.05)$} & \multicolumn{2}{|c|}{ significant $(P<0.01)$} & \\
\hline
\end{tabular}

(a) Only HI-Z tag(s) recaptured or stationary radio signal received.

(b) Fish free of passage-related visible injuries, scale loss ( $>20 \%$ per side), and loss of equilibrium.

${ }^{2}$ Email from Paul Heisey, Normandeau Associates, Inc., to Joanne Duncan, PNNL, September 9, 2009. 


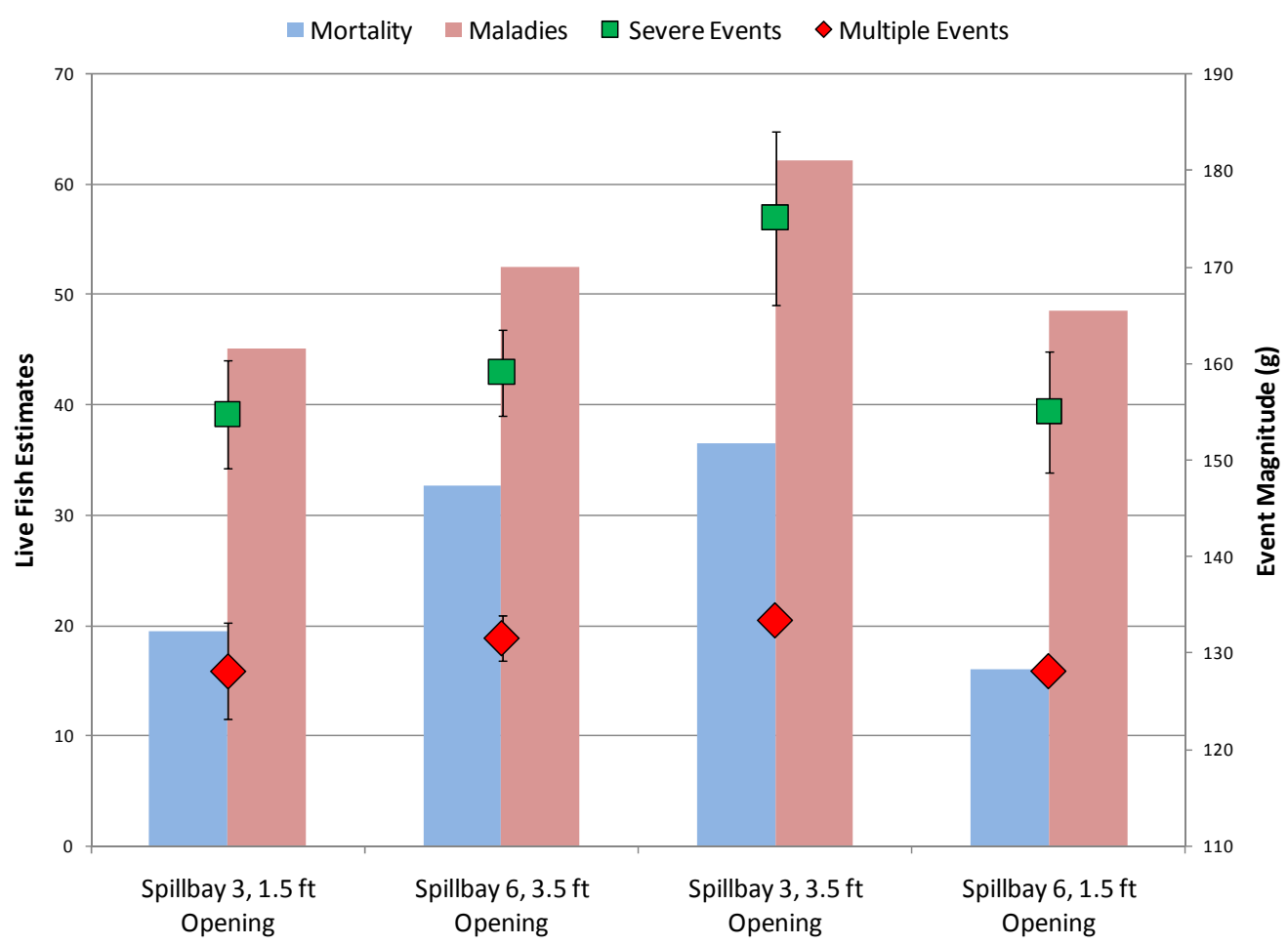

Figure 3.8. Live-fish mortality and malady estimates contrasted with Sensor Fish significant event magnitudes ( \pm standard error of the mean).

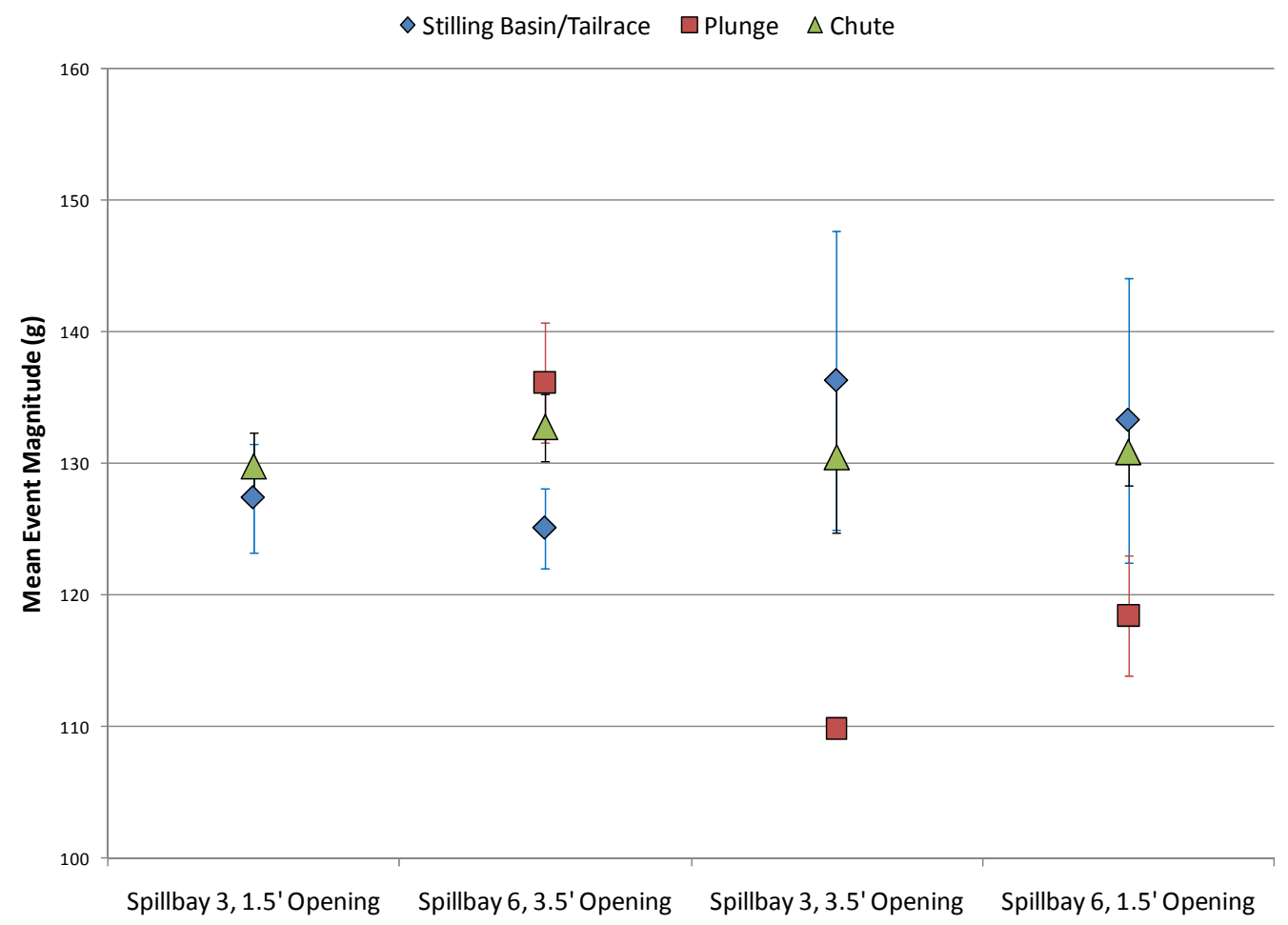

Figure 3.9. Sensor Fish event magnitudes ( \pm standard error of the mean) by region. 


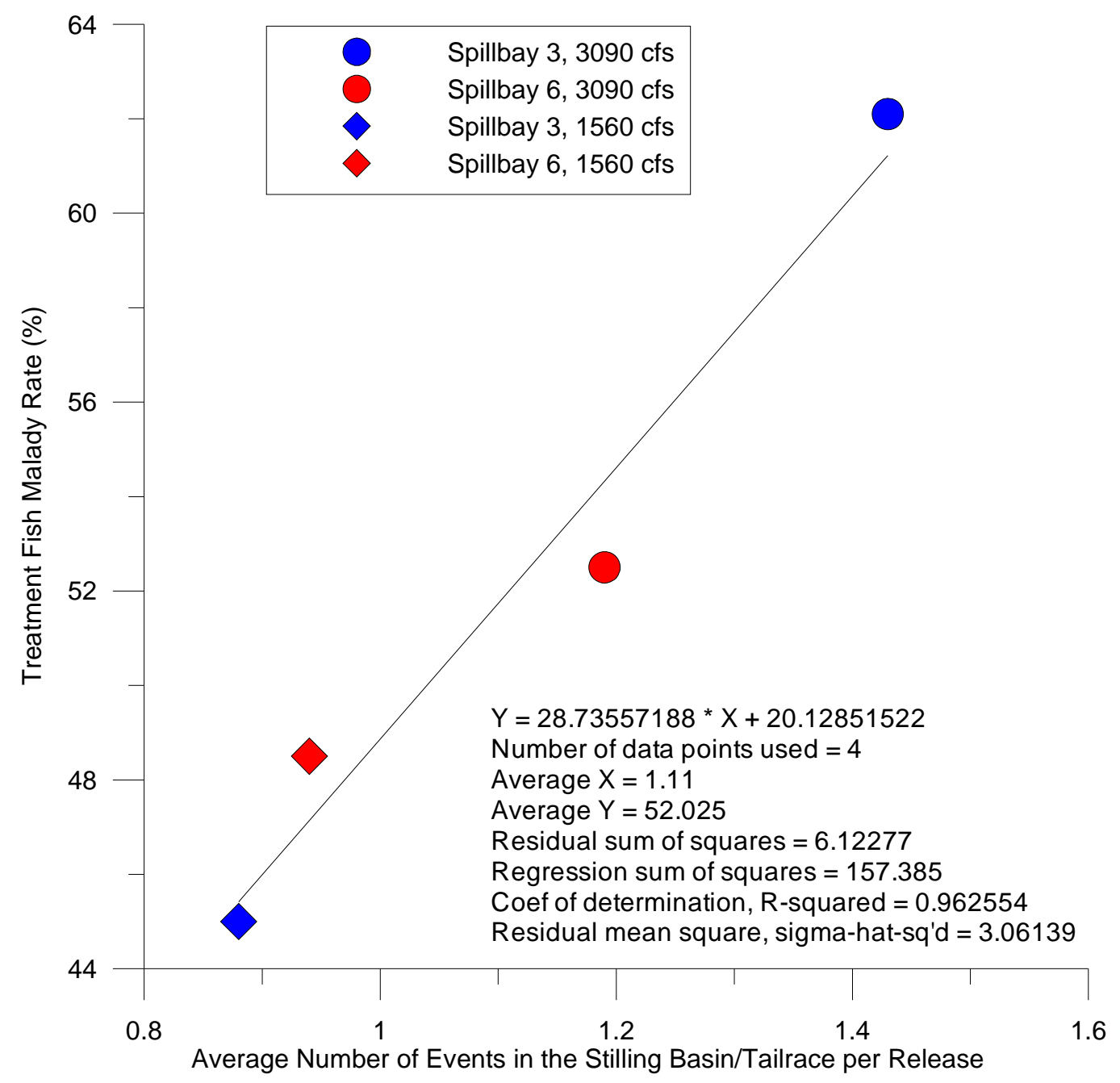

Figure 3.10. Relationship between live-fish estimated malady rate and average number of significant events occurring in the stilling basin per release. 


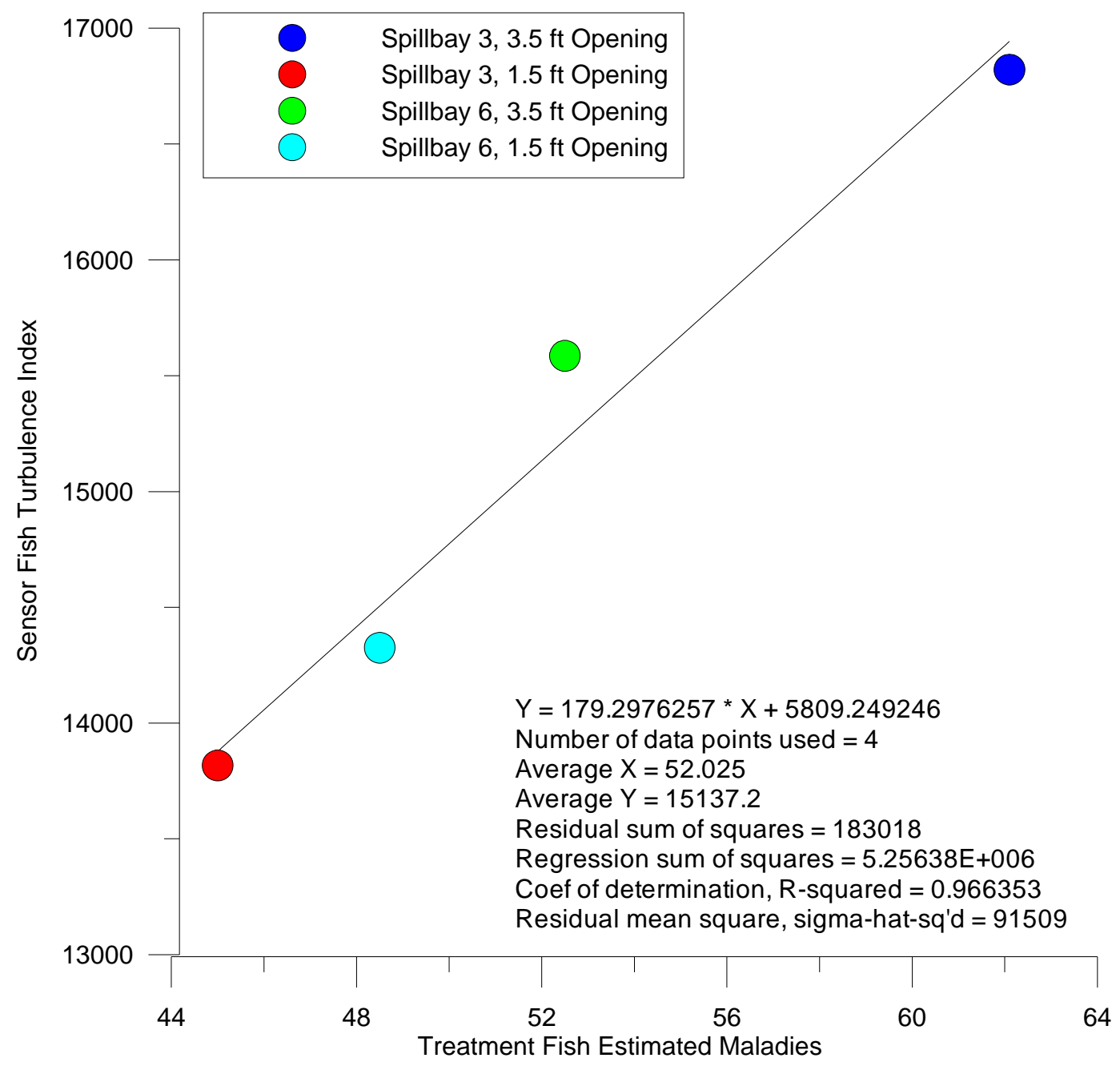

Figure 3.11. Relationship between live-fish estimated malady rate and Sensor Fish turbulence index. 


\subsection{Discussion}

The objective of this study was to describe and compare passage exposure conditions through Spillbay 3 and Spillbay 6 at two spillgate openings at Detroit Dam, using Sensor Fish to identify regions that may potentially cause fish injury or mortality. The study proved to be a challenge to Sensor Fish stamina as well as live-fish survival and injury.

The height and slope of the spillway chute contribute to deleterious exposure conditions observed during the study. Detroit Dam, completed in 1953, is slowing deteriorating due to age. The concrete surface of the spillway is rough from weathering (Figure 4.1), and the descending flow is irregular (Figure 4.2).

Spillbay 3 has no guidewalls, allowing the spill flow to thin and spread into the adjoining spillbays (Figure 4.3). Flow velocities exceed $150 \mathrm{ft} / \mathrm{s}$ before plunging into the stilling basin, often to depths of over $30 \mathrm{ft}$, at times striking rocks or other unidentified objects.

During passage, back pressure behind the tainter gate projects flow forward, resulting in a hydraulic jump as the flow contacts the spillway due to the angle of descent (53-degree slope). The gate opening size affects the time and distance the flow arches before contacting the chute, with the smaller opening propelling the Sensor Fish the greater distance (Figure 4.4). The flow depth and the position of the Sensor Fish within the flow will influence whether there is a relatively smooth transition onto the spillway chute or whether the passage will be more turbulent. Increased turbulence may fragment any flow jet, possibly creating more deleterious fish passage conditions.

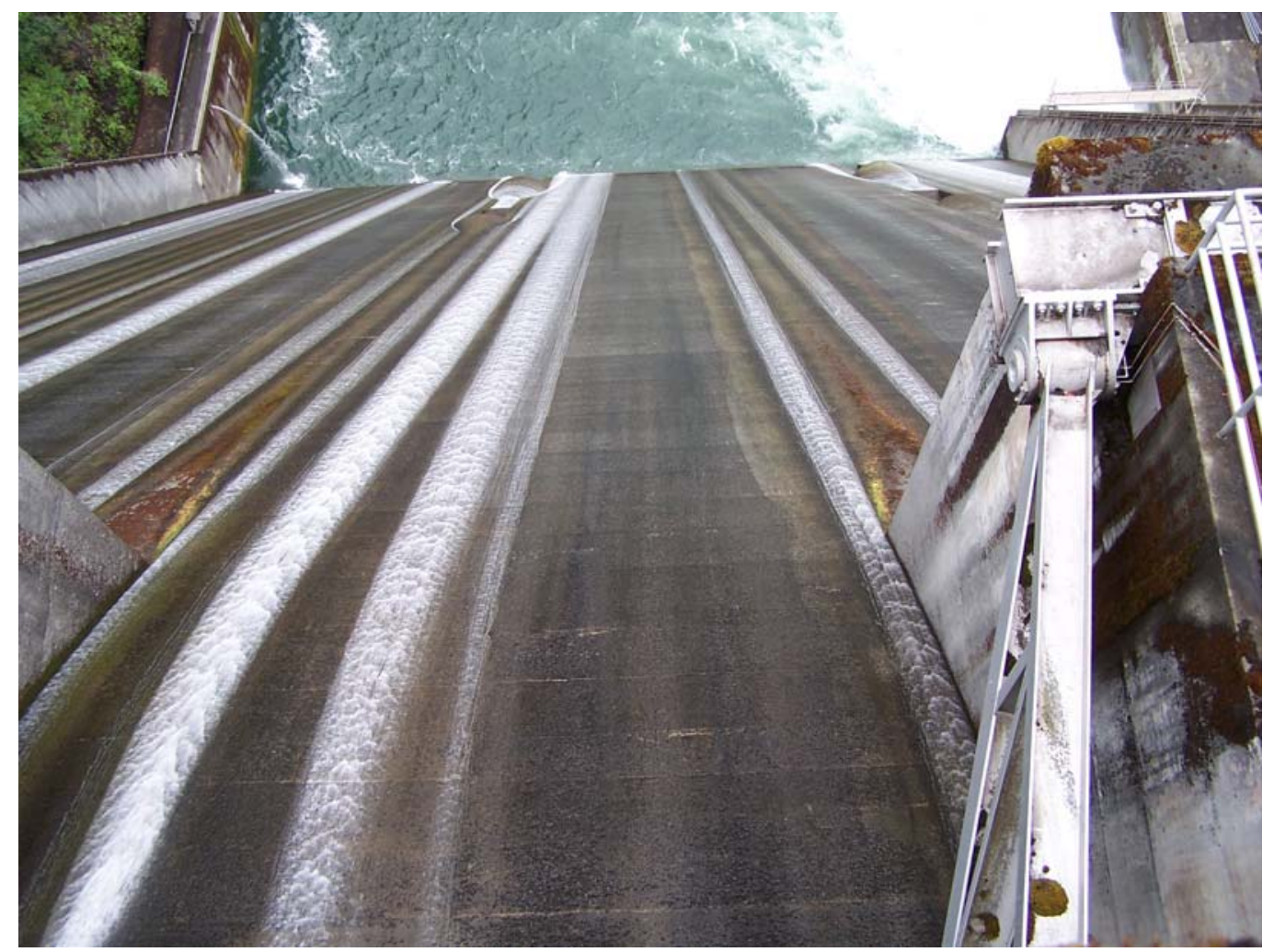

Figure 4.1. Spillbay 3 at Detroit Dam showing the rough, irregular concrete surface. 


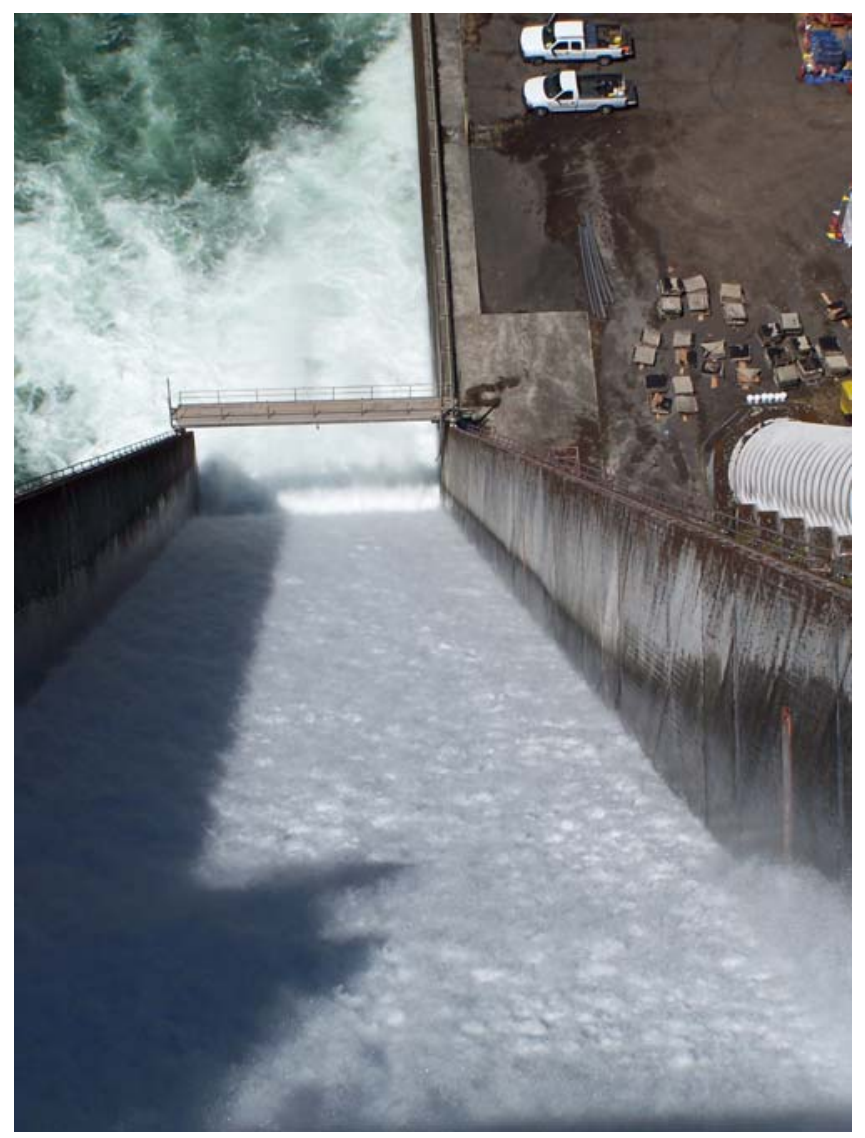

Figure 4.2. Spillbay 6 at Detroit Dam showing turbulent flow created on the rough spillway chute.

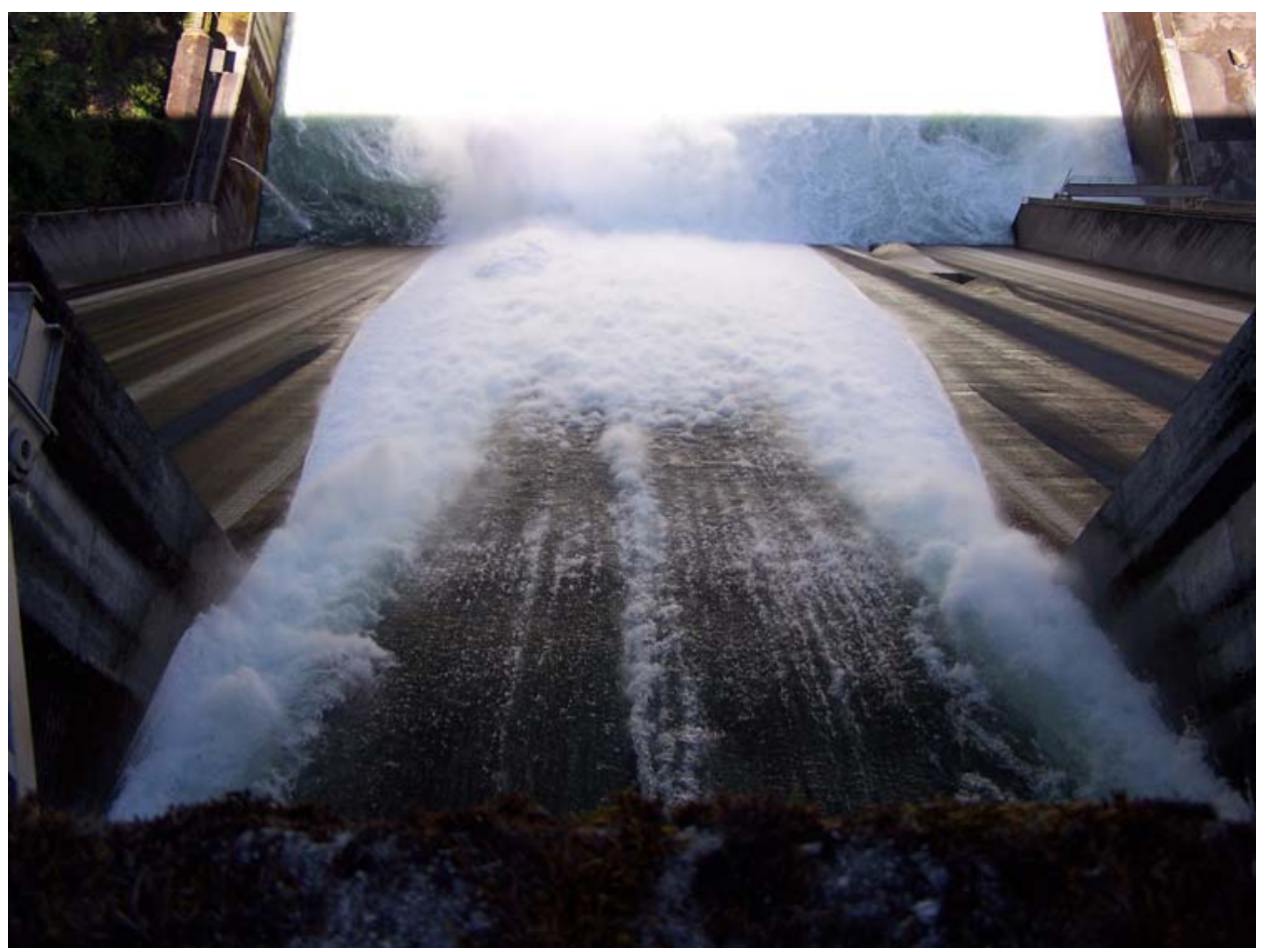

Figure 4.3. Flow through Spillbay 3 spreads to adjoining spillbays. 

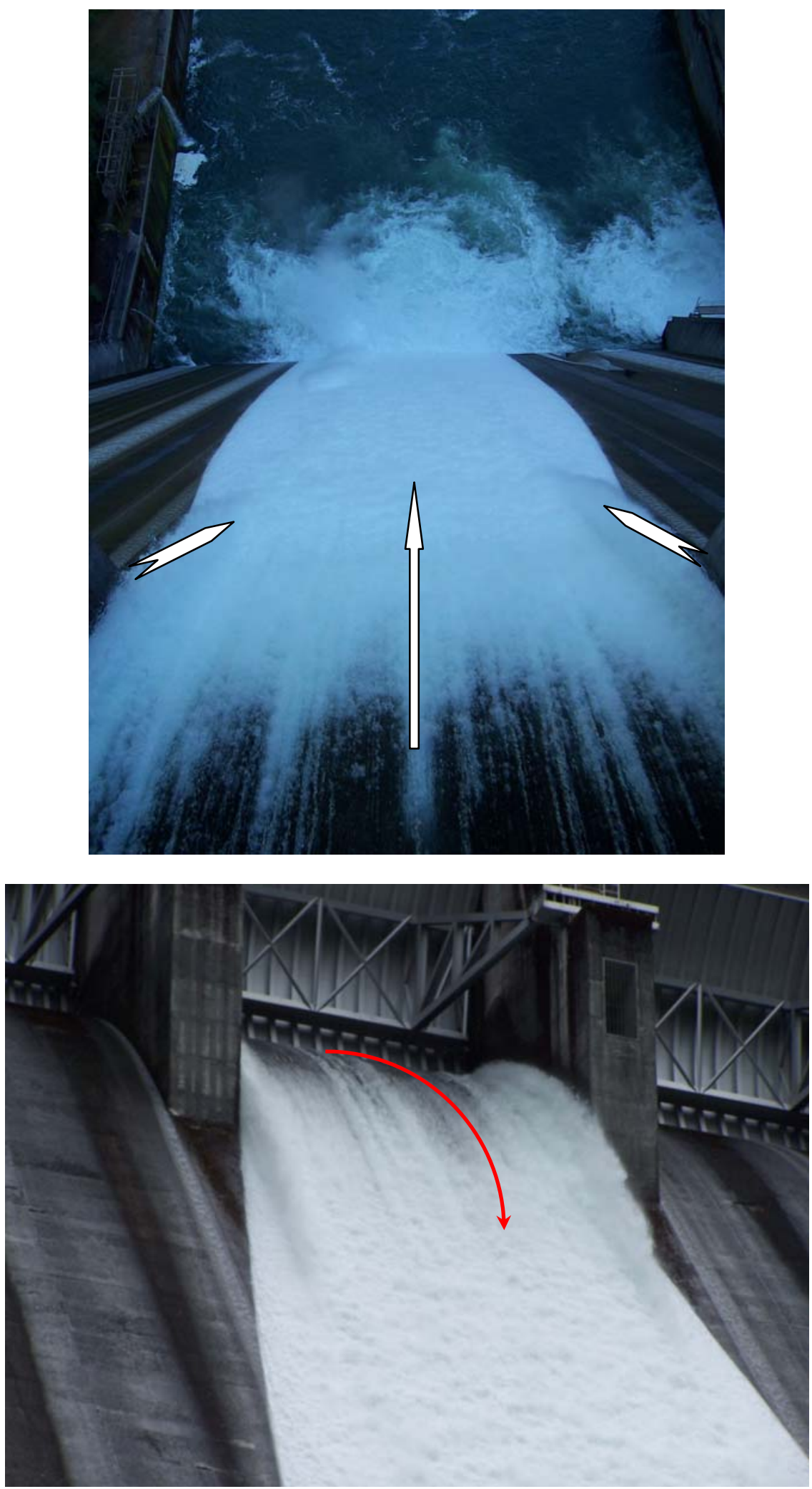

Figure 4.4. Hydraulic jump occurs as flow passes under the tainter gate. 
Some Sensor Fish recovered following passage through Detroit Dam were noticeably damaged, revealing scratches and portions of the polycarbonate shell chipped away (Figure 4.5). Extreme forces are needed to fragment polycarbonate, a highly impact-resistant, low-scratch durable polymer plastic. Although the Sensor Fish have been scratched and scraped during previous studies on the Columbia and Snake rivers, the damage observed on the casing following passage at Detroit Dam was much worse.

Results obtained from Sensor Fish data sets indicate that flow quality was inferior and the magnitudes of collision and shear events were more deleterious compared to those observed at Columbia and Snake river dams. Data from Sensor Fish following passage through the 3.5-ft tainter gate opening at both Spillway 3 and Spillway 6 incurred the highest significant event magnitudes-an average value of $175 \mathrm{~g}$ at Spillbay 3 and $159.1 \mathrm{~g}$ at Spillway 6 for the most severe events. Data obtained following passage through the 1.5-ft opening were nearly equivalent-154.73 $\mathrm{g}$ and $154.97 \mathrm{~g}$ for Spillbay 3 and Spillbay 6, respectively. Taking multiple events into account, mean values were $131.34 \mathrm{~g}, 131.05 \mathrm{~g}, 129.35 \mathrm{~g}$, and $129.02 \mathrm{~g}$ for Spillbay 3 (3.5-ft gate opening), Spillbay 6 (3.5-ft gate opening), Spillbay 3 (1.5-ft gate opening), and Spillbay 6 (1.5-ft gate opening), respectively.

Preliminary live-fish survival and malady estimates follow similar trends-estimated mortality estimates are 36.4, 32.6, 19.4, and 16\% for Spillbay 3 (3.5-ft gate opening), Spillbay 6 (3.5-ft gate opening), Spillbay 3 (1.5-ft gate opening), and Spillbay 6 (1.5-ft gate opening), respectively. Estimates for maladies are 62.1, 52.5, 48.5, and 45\% for Spillbay 3 (3.5-ft gate opening), Spillbay 6 (3.5-ft gate opening), Spillbay 6 (1.5-ft gate opening), and Spillbay 3 (1.5-ft gate opening), respectively. Sensor Fish turbulence index values follow trends similar to those observed for live-fish estimated maladies and observed Sensor Fish acceleration magnitudes.

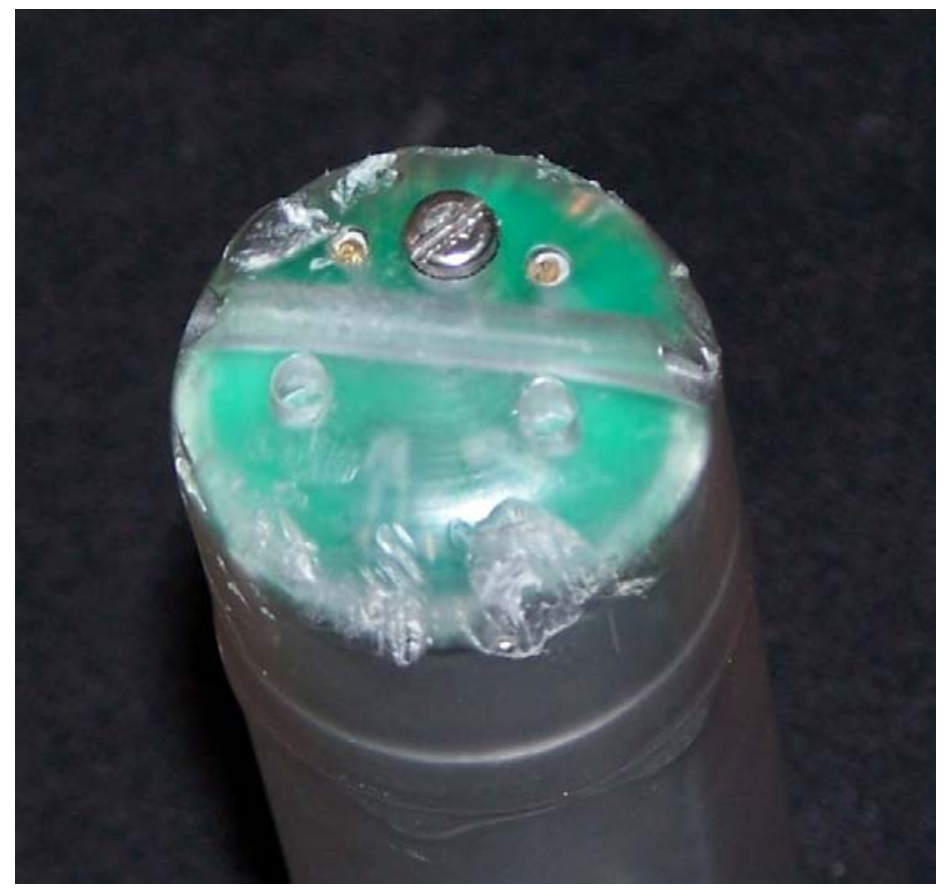

Figure 4.5. Chips and scratches visible on the polycarbonate Sensor Fish casing. 
The influence of elevation of entry into spillway approach flow using Sensor Fish and live fish has been evaluated at several Columbia and Snake River dams (Carlson and Duncan 2004, 2009; Carlson et al. 2006, 2008; Normandeau 2004, 2006; Normandeau et al. 2008; Normandeau and Skalski 2005, 2006a, 2006b). These studies indicate that elevation of entry influences the frequency of occurrence, location of occurrence, and type of significant event for Sensor Fish. They also show that elevation of entry influences the survival and injury rates of HI-Z-tagged juvenile Chinook salmon. Sensor Fish and HI-Z-tagged fish entering spill approach flow at deeper depths (lower elevations) have been found to have a higher probability of exposure to injurious or fatal events and higher exposure severity. The implication is that Sensor Fish and live fish that enter approach flow at lower elevations are nearer the spillway structure during spillway passage and are therefore more likely to experience collisions.

The USACE designed the current study to evaluate passage at target elevations approximately $3 \mathrm{ft}$ above the spillway crest for the 3.5 -ft tainter gate opening and $3 \mathrm{ft}$ above structure for the 1.5 - $\mathrm{ft}$ tainter gate opening. CFD model runs were used to determine the target locations, anticipating the injection depth to place the fish and Sensor Fish into flows of approximately $5 \mathrm{ft} / \mathrm{s}$. Sensor Fish Data indicate the target elevations were acquired and there were no significant event occurrences at the pipe exit. The premise that Sensor Fish entering approach flow at lower elevations are nearer the spillway structure during spillway passage and experience collisions on structure was supported during this evaluation, with $82.1 \%$ and $81.4 \%$ of the observed significant events occurring on the spillway chute for units passing via the 1.5-ft gate openings of Spillbay 3 and Spillbay 6, respectively. The slightly higher number of events observed on the spillway chute for Spillbay 3 might be attributed to the lessening of the flow depth as it proceeded down the spillway, due to the lack of guidewalls.

In a 2006 study at Ice Harbor Dam (Carlson et al. 2008), Sensor Fish experienced the highest percentage of collisions during passage-up to 76\% — due most likely to the spillway chute angle of descent ( 55-degree slope) and the deflector at its terminus. Although the Ice Harbor Dam slope is comparable to that of Detroit Dam (53-degree slope), the Ice Harbor drop in elevation is approximately $50 \mathrm{ft}$ while the Detroit Dam descent is more than $300 \mathrm{ft}$. As a result, the velocity of flow as it approaches the bottom of the spillway chute at Detroit Dam is more than double the velocity at Ice Harbor Dam.

During a 2006 evaluation at Trail Bridge Dam on the McKenzie River in Oregon, more than 85\% of the Sensor Fish experienced a significant event during spillway passage; $100 \%$ of the Sensor Fish passing through a 0.5 - $\mathrm{ft}$ gate opening (resulting in flows of approximately $400 \mathrm{cfs}$ ) experienced an event (Duncan and Carlson 2007). The spillway at Trail Bridge, approximately $50 \mathrm{ft}$ high and $237 \mathrm{ft}$ long with guidewalls on either side, has a 34\% slope. The spillway design differs from those of Ice Harbor and Detroit dams in that it transitions from a width of $30 \mathrm{ft}$ to $20 \mathrm{ft}$ and has a stilling basin "bowl" and a flip lip deflector. Mean significant event magnitudes for the 2006 Ice Harbor study, the Trail Bridge study, and the current evaluation at Detroit Dam were approximately $116 \mathrm{~g}, 139 \mathrm{~g}$, and $158 \mathrm{~g}$, respectively, for the most severe events per release. For all multiple events, mean magnitudes were $124 \mathrm{~g}, 126 \mathrm{~g}$, and $130 \mathrm{~g}$ for Ice Harbor, Trail Bridge, and Detroit dams, respectively. Clearly, the significant event magnitudes experienced at Detroit Dam are the most severe encountered during spillway passage to date. 


\subsection{Conclusions}

Exposure conditions observed from Sensor Fish time histories following passage through Detroit Dam spillways in July 2009 indicate conditions are unfavorable to the survival and well-being of both live fish and Sensor Fish. Nearly 100\% of the Sensor Fish experienced at least one significant acceleration magnitude event; the majority of events occurred on the spillway chutes. This number and percentage of collisions are much greater than those observed in previous investigations of passage through Columbia and Snake river dams.

The majority of Sensor Fish significant events observed during the study were classified as collisions - on the spillway chute, in the stilling basin/tailrace, or at the end of the spillway chute as the flow plunged into the stilling basin. The highest-magnitude collisions were observed on the spillway chute (up to $221 \mathrm{~g}$ ), although collisions as high as $179 \mathrm{~g}$ occurred in the stilling basin/tailrace. Shear events during the evaluation were infrequent (4\%) but were observed in all regions of spillway passage (spillway chute, the plunge region, and the stilling basin/tailrace). The majority of the shear events occurred following passage through the 3.5-ft tainter gate opening.

Few Sensor Fish (1.5\%) were observed to collide or experience a shear event as the units plunged into the stilling basin. The spillway angle of descent (53 degrees) and spillway chute length (over $400 \mathrm{ft}$ ) and height (approximately $340 \mathrm{ft}$ from the spillway crest to the tailrace) contribute to unfavorable passage conditions for fish.

Flow quality as computed using the Sensor Fish turbulence index was best for passage through Spillbay 3, 1.5-ft gate opening. The most inferior flow quality was observed though Spillbay 3 at the 3.5-ft gate opening.

Analysis of both the significant event data and turbulence index information indicates that passage through Spillway 3 at the 3.5-ft gate opening at Detroit Dam is the most detrimental to fish passage. 


\subsection{References}

Carlson TJ and JP Duncan. 2004. Characterization of Spillway Passage Conditions at Ice Harbor Dam, Snake River, Washington, 2003. PNWD-3462, Battelle-Pacific Northwest Division, Richland, Washington.

Carlson TJ and JP Duncan. 2009. Evaluation of Fish Passage Conditions for a Top Spillway Weir at John Day Dam Using the Sensor Fish. PNWD-4023, Battelle-Pacific Northwest Division, Richland, Washington.

Carlson TJ, JP Duncan, MC Richmond, JA Serkowski, and Z Deng. 2006. Characterization of Spillway Passage Conditions at Lower Monumental Dam, Snake River, Washington, 2005. PNWD-3662, BattellePacific Northwest Division, Richland, Washington.

Carlson TJ, JP Duncan, and Z Deng. 2008. Sensor Fish Characterization of Spillway Conditions at Ice Harbor Dam in 2004, 2005, and 2006. PNWD-3839, Battelle-Pacific Northwest Division, Richland, Washington.

Deng Z, TJ Carlson, JP Duncan, and MC Richmond. 2007. "Applications of the Sensor Fish Technology.” Hydro Review 26(5):34-41.

Duncan JP and TJ Carlson. 2007. Sensor Fish Characterization of Spillway Conditions at Trail Bridge Dam, McKenzie River, Oregon 2006. PNWD-3798, Battelle-Pacific Northwest Division, Richland, Washington.

Heisey PG, D Mathur, and T Rineer. 1992. "A Reliable Tag-Recapture Technique for Estimating Turbine Passage Survival: Application to Young-of-the-Year American Shad (Alosa sapidissima).” Canadian Journal of Fisheries and Aquatic Sciences 49:1826-1834.

NMFS. 2008. 2008 Willamette Project Biological Opinion. National Marine Fisheries Service, Seattle, Washington.

Normandeau Associates, Inc. 2004. Juvenile Salmonid Direct Survival/Injury in Passage through the Ice Harbor Dam Spillway, Snake River. Report prepared for the U.S. Army Corps of Engineers, Walla Walla District, Walla Walla, Washington.

Normandeau Associates, Inc. 2006. Direct Survival and Injury of Juvenile Salmon Passing Ice Harbor Spillway under Plunging, Skimming, and Undular Tailwater Conditions. Report prepared for the U.S. Army Corps of Engineers, Walla Walla District, Walla Walla, Washington.

Normandeau Associates, Inc. and J. R. Skalski. 2005. Effects of Differential Spill Volume and Entrainment Depth on Survival and Injury of Juvenile Salmonids at the Ice Harbor Dam Spillway, Snake River. Report prepared for the U.S. Army Corps of Engineers, Walla Walla District, Walla Walla, Washington. 
Normandeau Associates, Inc. and JR Skalski. 2006a. Comparative Assessment of Spillbay Passage Fish Condition and Survival for Installation of a Removable Spillway Weir at Lower Monumental Dam, Snake River. Report prepared for the U.S. Army Corps of Engineers, Walla Walla District, Walla Walla, Washington.

Normandeau Associates, Inc., and J. R. Skalski. 2006b. Comparative Direct Survival and Injury Rates of Juvenile Salmon Passing the New Removable Spillway Weir (RSW) and a Spillbay at Ice Harbor Dam, Snake River. Report prepared for the U.S. Army Corps of Engineers, Walla Walla District, Walla Walla, Washington.

Normandeau Associates, Inc., JR Skalski, and R Townsend. 2008. Direct Survival and Injury Evaluation of Juvenile Chinook Salmon Passing John Day Dam Spillway With and Without a Top Spillway Weir. Normandeau Associates, Inc., Drumore, Pennsylvania. 


\section{Appendix A}

\section{Field Log Data Sheets}

Appendix A contains field log data sheets showing dam operating conditions, release locations and deployment and recovery times for each Sensor Fish release, and other project information for the study period. 


\begin{tabular}{|c|c|c|c|c|c|c|c|c|c|c|c|}
\hline $\begin{array}{l}\text { Test } \\
\text { Date }\end{array}$ & Location & $\begin{array}{c}\text { Test } \\
\text { Condition }\end{array}$ & $\begin{array}{c}\text { Fish } \\
\text { ID }\end{array}$ & $\begin{array}{c}\text { Tag } \\
\text { Number }\end{array}$ & $\begin{array}{c}\text { Deployment } \\
\text { Time }\end{array}$ & $\begin{array}{l}\text { Recovery } \\
\text { Time }\end{array}$ & File Name & $\begin{array}{c}\text { Gate } \\
\text { Setting } \\
(\mathrm{ft})\end{array}$ & $\begin{array}{c}\text { Forebay } \\
\text { Elevation } \\
(\mathrm{ft})\end{array}$ & $\begin{array}{l}\text { Tailwater } \\
\text { Elevation } \\
\text { (ft) }\end{array}$ & Head \\
\hline \multirow[t]{7}{*}{$7 / 13 / 2009$} & SB3 & $1.5 \mathrm{ft}$ & 114 & 8961 & $11: 35$ & $11: 38$ & f114_SB3_PT1 & 1.5 & 1560.94 & 1200.30 & 360.64 \\
\hline & & & 723 & 8831 & $11: 36$ & $11: 38$ & ------- & & & & \\
\hline & & & 725 & 8870 & $16: 06$ & $16: 13$ & f725_SB3_pt2 & 1.5 & 1560.94 & 1200.30 & 360.64 \\
\hline & Control & 1.5-SB3 & 705 & 8851 & $12: 45$ & $12: 47$ & F705_Control & 1.5 & 1560.94 & 1200.30 & 360.64 \\
\hline & SB6 & $3.5 \mathrm{ft}$ & 722 & 8841 & $13: 41$ & $13: 52$ & f722_SB6_PT1 & 3.5 & 1560.94 & 1200.30 & 360.64 \\
\hline & & & 635 & 8971 & $14: 49$ & $14: 53$ & F635_sb6_pt2 & 3.5 & 1560.94 & 1200.30 & 360.64 \\
\hline & Control & 3.5-SB6 & 113 & 8891 & $15: 29$ & $15: 36$ & f113_control6 & 3.5 & 1560.94 & 1200.30 & 360.64 \\
\hline \multirow[t]{12}{*}{ 7/14/2009 } & SB3 & $1.5 \mathrm{ft}$ & 725 & 8870 & $8: 46$ & 9:09 & f725_SB3_1_1 & 1.5 & 1560.82 & 1200.04 & 360.38 \\
\hline & & & 101 & 8971 & $10: 22$ & $10: 28$ & f101_SB3_1_2 & 1.5 & 1560.83 & 1199.00 & 361.82 \\
\hline & & & 722 & 8841 & $10: 26$ & $10: 37$ & f722_SB3_1_3 & 1.5 & 1560.83 & 1199.00 & 361.82 \\
\hline & & & 711 & 8821 & $11: 52$ & $12: 00$ & f711_SB3_1_4 & 1.5 & 1560.83 & 1199.13 & 361.70 \\
\hline & Control & SB6 high & 103 & 8864 & $13: 15$ & $13: 23$ & f103_controlH_1 & 3.5 & 1560.85 & 1200.36 & 360.49 \\
\hline & Control & SB6 low & 114 & 8961 & $16: 59$ & $17: 04$ & f114_control_L_1 & 1.5 & 1560.80 & 1202.53 & 357.27 \\
\hline & SB6 & $3.5 \mathrm{ft}$ & 117 & 8831 & $14: 08$ & $14: 21$ & f117_SB6_3_1 & 3.5 & 1560.83 & 1200.36 & 360.49 \\
\hline & & & 661 & 8911 & $15: 20$ & $15: 49$ & f661_SB6_3_2 & 3.5 & 1560.83 & 1200.23 & 360.50 \\
\hline & & & 714 & 8861 & $15: 26$ & $15: 32$ & ------- & & 1560.83 & 1200.23 & 360.50 \\
\hline & & & 725 & 8870 & $15: 25$ & $15: 30$ & ------- & & 1560.83 & 1200.23 & 360.50 \\
\hline & & & 101 & 8971 & $16: 12$ & $16: 23$ & f101_SB6_3_3 & 3.5 & 1560.83 & 1202.30 & 358.50 \\
\hline & & & 722 & 8841 & $16: 18$ & $16: 27$ & f722_SB6_3_4 & 3.5 & 1560.83 & 1202.30 & 358.50 \\
\hline \multirow[t]{4}{*}{ 7/15/2009 } & SB3 & $1.5 \mathrm{ft}$ & 722 & 8841 & $8: 47$ & $8: 57$ & f722_SB3_1_5 & 1.5 & 1560.63 & 1200.36 & 360.27 \\
\hline & & & 101 & 8971 & $8: 51$ & $8: 55$ & f101_SB3_1_6 & 1.5 & 1560.63 & 1200.36 & 360.27 \\
\hline & & & 711 & 8821 & $9: 29$ & $9: 41$ & f711_SB3_1_7 & 1.5 & 1560.63 & 1200.90 & 359.73 \\
\hline & & & 661 & 8911 & 9:33 & $9: 40$ & f661_SB3_1_8 & 1.5 & 1560.63 & 1200.90 & 359.73 \\
\hline
\end{tabular}




\begin{tabular}{|c|c|c|c|c|c|c|c|c|c|}
\hline Test Date & File Name & $\begin{array}{l}\text { Spillbay } \\
6 \text { (cfs) }\end{array}$ & $\begin{array}{l}\text { Spillbay } 3 \\
\text { (cfs) }\end{array}$ & $\begin{array}{l}\text { Gage } \\
\text { Counter } \\
\text { SB } 6\end{array}$ & $\begin{array}{l}\text { Gage } \\
\text { Counter } \\
\text { SB } 3\end{array}$ & $\begin{array}{c}\text { Number of } \\
\text { Turbines } \\
\text { Operating }\end{array}$ & $\begin{array}{c}\text { Total } \\
\text { Powerhouse } \\
\text { flow (cfs) }\end{array}$ & $\begin{array}{c}\text { Total } \\
\text { Project } \\
\text { Flow } \\
\text { (cfs)* }\end{array}$ & $\begin{array}{c}\text { Approximate Velocity at } \\
\text { Plunge }\end{array}$ \\
\hline \multirow[t]{7}{*}{$7 / 13 / 2009$} & f114_SB3_PT1 & 4600 & 1549 & 1100 & 38 & 0 & 0 & 2600 & 152.3367 \\
\hline & (------ & & & & & & & & \\
\hline & f725_SB3_pt2 & 0 & 1549 & 0 & 0 & 1 & 1960 & 3509 & 152.3367 \\
\hline & F705_Control & 4600 & 1549 & 1100 & 38 & 0 & 0 & 2009 & \\
\hline & f722_SB6_PT1 & 3008 & 0 & 70 & 0 & 0 & 0 & 3008 & 152.3367 \\
\hline & F635_sb6_pt2 & 3008 & 0 & 70 & 0 & 0 & 0 & 3008 & 152.3367 \\
\hline & f113_control6 & 3008 & 0 & 70 & 0 & 0 & 0 & 3008 & \\
\hline \multirow[t]{12}{*}{$7 / 14 / 2009$} & f725_SB3_1_1 & 460 & 1549 & 11 & 38 & 0 & 0 & 2009 & 152.3662 \\
\hline & f101_SB3_1_2 & 50 & 1549 & 1 & 38 & 0 & 0 & 1599 & 152.5878 \\
\hline & f722_SB3_1_3 & 50 & 1549 & 1 & 38 & 0 & 0 & 1599 & 152.5878 \\
\hline & f711_SB3_1_4 & 50 & 1549 & 1 & 38 & 0 & 0 & 1599 & 152.5604 \\
\hline & f103_controlH_1 & 3008 & 0 & 70 & 0 & 0 & 0 & 3008 & \\
\hline & f114_control_L_1 & 1549 & 0 & 36 & 0 & 1 & 1960 & 3509 & \\
\hline & f117_SB6_3_1 & 3008 & 0 & 70 & 0 & 0 & 0 & 3008 & 152.3008 \\
\hline & f661_SB6_3_2 & 3008 & 0 & 70 & 0 & 1 & 1960 & 4968 & 152.3282 \\
\hline & ------- & 3008 & 0 & 70 & 0 & 1 & 1960 & 4968 & 152.3282 \\
\hline & ------- & 3008 & 0 & 70 & 0 & 1 & 1960 & 4968 & 152.3282 \\
\hline & f101_SB6_3_3 & 3008 & 0 & 70 & 0 & 1 & 1960 & 4968 & 151.8904 \\
\hline & f722_SB6_3_4 & 3008 & 0 & 70 & 0 & 1 & 1960 & 4968 & 151.8904 \\
\hline \multirow[t]{4}{*}{$7 / 15 / 2009$} & f722_SB3_1_5 & 460 & 1549 & 11 & 38 & 0 & 0 & 2009 & 152.2585 \\
\hline & f101_SB3_1_6 & 460 & 1549 & 11 & 38 & 0 & 0 & 2009 & 152.2585 \\
\hline & f711_SB3_1_7 & 460 & 1549 & 11 & 38 & 0 & 0 & 2009 & 152.1444 \\
\hline & f661_SB3_1_8 & 460 & 1549 & 11 & 38 & 0 & 0 & 2009 & 152.1444 \\
\hline
\end{tabular}




\begin{tabular}{|c|c|c|c|c|c|c|c|c|c|c|c|}
\hline Test Date & Location & $\begin{array}{c}\text { Test } \\
\text { Condition } \\
\end{array}$ & $\begin{array}{c}\text { Fish } \\
\text { ID }\end{array}$ & $\begin{array}{c}\text { Tag } \\
\text { Number }\end{array}$ & $\begin{array}{c}\text { Deployment } \\
\text { Time }\end{array}$ & $\begin{array}{c}\text { Recovery } \\
\text { Time }\end{array}$ & File Name & $\begin{array}{c}\text { Gate } \\
\text { Setting } \\
\text { (ft) }\end{array}$ & $\begin{array}{c}\text { Forebay } \\
\text { Elevation } \\
(\mathrm{ft})\end{array}$ & $\begin{array}{c}\text { Tailwater } \\
\text { Elevation } \\
(\mathrm{ft})\end{array}$ & Head \\
\hline \multirow[t]{16}{*}{$7 / 15 / 2009$} & SB3 & $1.5 \mathrm{ft}$ & 117 & 8831 & 10:09 & 10:15 & ------- & & 1560.63 & 1200.40 & 360.23 \\
\hline & & & 116 & 8870 & 10:05 & 10:09 & f116_SB3_1_9 & 1.5 & 1560.63 & 1200.40 & 360.23 \\
\hline & & & 114 & 8961 & $10: 38$ & $10: 49$ & f114_SB3_1_10 & 1.5 & 1560.63 & 1200.40 & 360.23 \\
\hline & & & 103 & 8864 & $10: 42$ & $10: 50$ & f103_SB3_1_11 & 1.5 & 1560.63 & 1200.40 & 360.23 \\
\hline & Control & SB6 low & 106 & 8881 & 11:29 & $11: 40$ & f106_control_L_2 & 1.5 & 1560.63 & 1200.40 & 360.23 \\
\hline & Control & SB6 low & 104 & 8851 & 11:31 & $11: 38$ & f104_control_L_3 & 1.5 & 1560.63 & 1200.40 & 360.23 \\
\hline & SB6 & $\sim 3.5$ & 722 & 8841 & $12: 25$ & $12: 37$ & f722_SB6_3_5 & 3.5 & 1560.63 & 1200.30 & 360.33 \\
\hline & & & 101 & 8971 & $12: 29$ & $12: 41$ & f101_SB6_3_6 & 3.5 & 1560.63 & 1200.30 & 360.33 \\
\hline & & & 109 & 8891 & 13:12 & $13: 22$ & f109_SB6_3_7 & 3.5 & 1560.62 & 1199.70 & 360.92 \\
\hline & & & 711 & 8821 & 13:16 & 13:26 & f711_SB6_3_8 & 3.5 & 1560.62 & 1199.70 & 360.92 \\
\hline & & & 661 & 8911 & 14:00 & $14: 16$ & f661_SB6_3_9 & 3.5 & 1560.62 & 1202.10 & 358.52 \\
\hline & & & 116 & 8870 & 14:04 & $14: 11$ & ------- & & 1560.62 & 1202.10 & 358.52 \\
\hline & & & 114 & 8961 & 14:52 & $15: 11$ & f114_SB6_3_10 & 3.5 & 1560.58 & 1202.10 & 358.48 \\
\hline & & & 103 & 8864 & 14:56 & 15:04 & f103_SB6_3_11 & 3.5 & 1560.58 & 1202.10 & 358.48 \\
\hline & Control & SB6 high & 117 & 8831 & 15:31 & $15: 45$ & f117_Control_H_2 & 3.5 & 1560.54 & 1202.10 & 358.44 \\
\hline & & & 106 & 8881 & $15: 34$ & $15: 42$ & f106_Control_H_3 & 3.5 & 1560.54 & 1202.10 & 358.44 \\
\hline \multirow[t]{8}{*}{$7 / 16 / 2009$} & SB6 & $\sim 3.5$ & 114 & 8961 & 7:36 & 8:03 & f114_SB6_3_12 & 3.5 & 1560.35 & 1200.30 & 360.05 \\
\hline & & & 661 & 8911 & $7: 40$ & $7: 47$ & f661_SB6_3_13 & 3.5 & 1560.35 & 1200.30 & 360.05 \\
\hline & & & 711 & 8821 & $8: 21$ & $8: 36$ & f711_SB6_3_14 & 3.5 & 1560.34 & 1200.50 & 360.04 \\
\hline & & & 722 & 8841 & $8: 21$ & $8: 44$ & f722_SB6_3_15 & 3.5 & 1560.34 & 1200.50 & 360.04 \\
\hline & & & 117 & 8831 & $9: 10$ & 9:14 & ------- & & 1560.34 & 1199.20 & 361.14 \\
\hline & & & 106 & 8881 & 9:14 & 9:25 & f106_SB6_3_16 & 3.5 & 1560.34 & 1199.20 & 361.14 \\
\hline & & & 103 & 8864 & 10:04 & $10: 32$ & f103_SB6_3_17 & 3.5 & 1560.34 & 1199.20 & 361.14 \\
\hline & & & 101 & 8971 & 10:09 & $10: 17$ & f101_SB6_3_18 & 3.5 & 1560.34 & 1199.20 & 361.14 \\
\hline
\end{tabular}




\begin{tabular}{|c|c|c|c|c|c|c|c|c|c|}
\hline Test Date & File Name & $\begin{array}{l}\text { Spillbay } 6 \\
\text { (cfs) }\end{array}$ & $\begin{array}{l}\text { Spillbay } \\
3 \text { (cfs) }\end{array}$ & $\begin{array}{c}\text { Gage } \\
\text { Counter } \\
\text { SB 6 }\end{array}$ & $\begin{array}{c}\text { Gage } \\
\text { Counter } \\
\text { SB 3 }\end{array}$ & $\begin{array}{c}\text { Number of } \\
\text { Turbines } \\
\text { Operating }\end{array}$ & $\begin{array}{c}\text { Total } \\
\text { Powerhouse } \\
\text { flow (cfs) }\end{array}$ & $\begin{array}{c}\text { Total } \\
\text { Project } \\
\text { Flow (cfs)* }\end{array}$ & $\begin{array}{c}\text { Approximate } \\
\text { Velocity at Plunge }\end{array}$ \\
\hline \multirow[t]{16}{*}{ 7/15/2009 } & |------ & 460 & 1549 & 11 & 38 & 0 & 0 & 2009 & 152.25006 \\
\hline & f116_SB3_1_9 & 460 & 1549 & 11 & 38 & 0 & 0 & 2009 & 152.25006 \\
\hline & f114_SB3_1_10 & 460 & 1549 & 11 & 38 & 0 & 0 & 2009 & 152.25006 \\
\hline & f103_SB3_1_11 & 460 & 1549 & 11 & 38 & 0 & 0 & 2009 & 152.25006 \\
\hline & f106_control_L_2 & 1537 & 0 & 36 & 0 & 0 & 0 & 1259 & \\
\hline & f104_control_L_3 & 1537 & 0 & 36 & 0 & 0 & 0 & 1259 & \\
\hline & f722_SB6_3_5 & 3008 & 0 & 70 & 0 & 0 & 0 & 3008 & 152.27119 \\
\hline & f101_SB6_3_6 & 3008 & 0 & 70 & 0 & 0 & 0 & 3008 & 152.27119 \\
\hline & f109_SB6_3_7 & 3008 & 0 & 70 & 0 & 0 & 0 & 3008 & 152.3958 \\
\hline & f711_SB6_3_8 & 3008 & 0 & 70 & 0 & 0 & 0 & 3008 & 152.3958 \\
\hline & f661_SB6_3_9 & 3008 & 0 & 70 & 0 & 0 & 0 & 3008 & 151.88826 \\
\hline & ------- & 3008 & 0 & 70 & 0 & 0 & 0 & 3008 & 151.88826 \\
\hline & f114_SB6_3_10 & 3008 & 0 & 70 & 0 & 1 & 1962 & 4970 & 151.87979 \\
\hline & f103_SB6_3_11 & 3008 & 0 & 70 & 0 & 1 & 1962 & 4970 & 151.87979 \\
\hline & f117_Control_H_2 & 3008 & 0 & 70 & 0 & 1 & 1962 & 4970 & \\
\hline & f106_Control_H_3 & 3008 & 0 & 70 & 0 & 1 & 1962 & 4970 & \\
\hline \multirow[t]{8}{*}{$7 / 16 / 2009$} & f114_SB6_3_12 & 3008 & 0 & 70 & 0 & 0 & 0 & 3008 & 152.21201 \\
\hline & f661_SB6_3_13 & 3008 & 0 & 70 & 0 & 0 & 0 & 3008 & 152.21201 \\
\hline & f711_SB6_3_14 & 3008 & 0 & 70 & 0 & 0 & 0 & 3008 & 152.16762 \\
\hline & f722_SB6_3_15 & 3008 & 0 & 70 & 0 & 0 & 0 & 3008 & 152.16762 \\
\hline & ------- & 3008 & 0 & 70 & 0 & 0 & 0 & 3008 & 152.44224 \\
\hline & f106_SB6_3_16 & 3008 & 0 & 70 & 0 & 0 & 0 & 3008 & 152.44224 \\
\hline & f103_SB6_3_17 & 3008 & 0 & 70 & 0 & 0 & 0 & 3008 & 152.44224 \\
\hline & f101_SB6_3_18 & 3008 & 0 & 70 & 0 & 0 & 0 & 3008 & 152.44224 \\
\hline
\end{tabular}




\begin{tabular}{|c|c|c|c|c|c|c|c|c|c|c|c|}
\hline Test Date & Location & $\begin{array}{c}\text { Test } \\
\text { Condition }\end{array}$ & $\begin{array}{l}\text { Fish } \\
\text { ID }\end{array}$ & $\begin{array}{c}\text { Tag } \\
\text { Number }\end{array}$ & $\begin{array}{l}\text { Deployment } \\
\text { Time }\end{array}$ & $\begin{array}{c}\text { Recovery } \\
\text { Time }\end{array}$ & File Name & $\begin{array}{l}\text { Gate } \\
\text { Setting } \\
(\mathrm{ft})\end{array}$ & $\begin{array}{c}\text { Forebay } \\
\text { Elevation } \\
(\mathrm{ft})\end{array}$ & $\begin{array}{c}\text { Tailwater } \\
\text { Elevation } \\
\text { (ft) }\end{array}$ & Head \\
\hline \multirow[t]{12}{*}{$7 / 16 / 2009$} & Control & SB6 high & 705 & 8870 & $10: 54$ & $11: 07$ & ------- & & & & \\
\hline & & & 104 & 8851 & 10:59 & 11:05 & f104_control_H_4 & 3.5 & 1560.34 & 1199.80 & 360.54 \\
\hline & SB3 & $1.5 \mathrm{ft}$ & 109 & 8891 & 11:51 & 12:05 & f109_SB3_1_12 & 1.5 & 1560.33 & 1202.10 & 358.23 \\
\hline & & & 114 & 8961 & 11:54 & $12: 04$ & f114_SB3_1_13 & 1.5 & 1560.33 & 1202.10 & 358.23 \\
\hline & & & 661 & 8911 & $12: 48$ & 12:56 & f661_SB3_1_14 & 1.5 & 1560.33 & 1201.90 & 358.43 \\
\hline & & & 711 & 8821 & $12: 44$ & $12: 57$ & f711_SB3_1_15 & 1.5 & 1560.33 & 1201.90 & 358.43 \\
\hline & & & 722 & 8841 & 13:40 & 13:46 & f722_SB3_1_16 & 1.5 & 1560.33 & 1200.00 & 360.33 \\
\hline & & & 106 & 8881 & 13:37 & $13: 48$ & f106_SB3_1_17 & 1.5 & 1560.33 & 1200.00 & 360.33 \\
\hline & & & 119 & 8831 & $14: 24$ & $14: 28$ & f119_SB3_1_18 & 1.5 & 1560.33 & 1199.80 & 360.53 \\
\hline & & & 103 & 8864 & $14: 27$ & 14:34 & f103_SB3_1_19 & 1.5 & 1560.33 & 1199.80 & 360.53 \\
\hline & Control & SB6 low & 101 & 8971 & $15: 21$ & $15: 26$ & f101_control_L_4 & 1.5 & 1560.33 & 1199.80 & 360.53 \\
\hline & & & 723 & 8870 & $15: 17$ & $15: 28$ & ------- & & & & \\
\hline \multirow[t]{16}{*}{ 7/17/2009 } & SB6 & $\sim 3.5$ & 104 & 8851 & $7: 53$ & $8: 11$ & F104_SB6_3_19 & 3.5 & 1560.16 & 1201.70 & 359.09 \\
\hline & & & $656^{*}$ & 8870 & $7: 56$ & 8:08 & ------- & & 1560.16 & 1201.70 & 359.09 \\
\hline & & & 109 & 8891 & 8:39 & $8: 56$ & f109_SB6_3_20 & 3.5 & 1560.16 & 1201.70 & 359.09 \\
\hline & & & $102 *$ & 8841 & $8: 43$ & $8: 57$ & f102_SB6_3_21 & 3.5 & 1560.16 & 1201.70 & 359.09 \\
\hline & & & 711 & 8821 & 9:36 & $9: 53$ & f711_SB6_3_22 & 3.5 & 1560.16 & 1200.70 & 360.09 \\
\hline & & & $729 *$ & 8931 & $9: 40$ & $9: 45$ & f114_SB6_3_23 & 3.5 & 1560.16 & 1200.70 & 360.09 \\
\hline & & & 119 & 8831 & $10: 30$ & $10: 46$ & f119_SB6_3_24 & 3.5 & 1560.15 & 1199.90 & 360.25 \\
\hline & & & $687 *$ & 8881 & 10:34 & $10: 40$ & f687_SB6_3_25 & & & & \\
\hline & Control & SB6 high & 103 & 8864 & $12: 24$ & $12: 43$ & f103_control_H_5 & 3.5 & 1560.13 & 1200.20 & 360.11 \\
\hline & SB3 & $1.5 \mathrm{ft}$ & 661 & 8911 & 13:55 & 14:13 & f661_SB3_1_20 & 1.5 & 1560.12 & 1202.10 & 358.02 \\
\hline & & & $664 *$ & & 14:00 & 14:15 & ------- & & & & \\
\hline & & & 104 & 8851 & 14:53 & 14:59 & ------- & & 1560.09 & 1203.70 & 356.39 \\
\hline & & & $102 *$ & 8841 & $14: 58$ & $15: 04$ & ------- & & & & \\
\hline & & & 109 & 8131 & 15:46 & 15:50 & f109_SB3_1_21 & 1.5 & 1560.04 & 1202.80 & 357.24 \\
\hline & & & 711 & 8821 & 16:25 & 16:28 & f711_SB3_1_22 & 1.5 & 1560.04 & 1202.80 & 357.24 \\
\hline & Control & SB6 low & 106 & 8881 & 17:05 & $17: 11$ & f106_control_L_5 & 1.5 & 1560.03 & 1203.10 & 356.93 \\
\hline
\end{tabular}




\begin{tabular}{|c|c|c|c|c|c|c|c|c|c|}
\hline Test Date & File Name & $\begin{array}{c}\text { Spillbay } 6 \\
\text { (cfs) }\end{array}$ & $\begin{array}{c}\text { Spillbay } 3 \\
\text { (cfs) }\end{array}$ & $\begin{array}{c}\text { Gage } \\
\text { Counter } \\
\text { SB } 6 \\
\end{array}$ & $\begin{array}{c}\text { Gage } \\
\text { Counter } \\
\text { SB } 3 \\
\end{array}$ & $\begin{array}{c}\text { Number of } \\
\text { Turbines } \\
\text { Operating }\end{array}$ & $\begin{array}{c}\text { Total } \\
\text { Powerhouse } \\
\text { flow (cfs) }\end{array}$ & $\begin{array}{c}\text { Total } \\
\text { Project } \\
\text { Flow (cfs)* }\end{array}$ & $\begin{array}{c}\text { Approximate } \\
\text { Velocity at } \\
\text { Plunge }\end{array}$ \\
\hline \multirow[t]{11}{*}{$7 / 16 / 2009$} & ------ & & & & & & & & \\
\hline & f104_control_H_4 & 3008 & 0 & 70 & 0 & 0 & 0 & 3008 & \\
\hline & f109_SB3_1_12 & 460 & 1549 & 11 & 38 & 0 & 0 & 2009 & 151.82682 \\
\hline & f114_SB3_1_13 & 460 & 1549 & 11 & 38 & 0 & 0 & 2009 & 151.82682 \\
\hline & f661_SB3_1_14 & 460 & 1549 & 11 & 38 & 0 & 0 & 2009 & 151.8692 \\
\hline & f711_SB3_1_15 & 460 & 1549 & 11 & 38 & 0 & 0 & 2009 & 151.8692 \\
\hline & f722_SB3_1_16 & 460 & 1549 & 11 & 38 & 0 & 0 & 2009 & 152.27119 \\
\hline & f106_SB3_1_17 & 460 & 1549 & 11 & 38 & 0 & 0 & 2009 & 152.27119 \\
\hline & f119_SB3_1_18 & 460 & 1549 & 11 & 38 & 1 & 1970 & 3979 & 152.31344 \\
\hline & f103_SB3_1_19 & 460 & 1549 & 11 & 38 & 1 & 1970 & 3979 & 152.31344 \\
\hline & f101_control_L_4 & 1537 & 0 & 36 & 0 & 1 & 1970 & 3607 & \\
\hline \multirow{16}{*}{ 7/17/2009 } & F104_SB6_3_19 & 3008 & 0 & 70 & 0 & 0 & 0 & 3008 & 151.87555 \\
\hline & ----- & 3008 & 0 & 70 & 0 & 0 & 0 & 3008 & 151.87555 \\
\hline & f109_SB6_3_20 & 3008 & 0 & 70 & 0 & 0 & 0 & 3008 & 151.87555 \\
\hline & f102_SB6_3_21 & 3008 & 0 & 70 & 0 & 0 & 0 & 3008 & 151.87555 \\
\hline & f711_SB6_3_22 & 3008 & 0 & 70 & 0 & 0 & 0 & 3008 & 152.08725 \\
\hline & f114_SB6_3_23 & 3008 & 0 & 70 & 0 & 0 & 0 & 3008 & 152.08725 \\
\hline & f119_SB6_3_24 & 3008 & 0 & 70 & 0 & 0 & 0 & 3008 & 152.25428 \\
\hline & f687_SB6_3_25 & & & & & & & & \\
\hline & f103_control_H_5 & 3008 & 0 & 70 & 0 & 0 & 0 & 3008 & \\
\hline & f661_SB3_1_20 & 460 & 1549 & 11 & 38 & 1 & 1970 & 3979 & 151.78231 \\
\hline & ------- & & & & & & & & \\
\hline & ------- & 460 & 1549 & 11 & 38 & 1 & 1970 & 3979 & 151.4364 \\
\hline & ------- & & & & & & & & \\
\hline & f109_SB3_1_21 & 460 & 1549 & 11 & 38 & 1 & 1970 & 3979 & 151.61688 \\
\hline & f711_SB3_1_22 & 460 & 1549 & 11 & 38 & 1 & 1970 & 3979 & 151.61688 \\
\hline & f106_control_L_5 & 1549 & 0 & 36 & 0 & 1 & 1970 & 3519 & \\
\hline
\end{tabular}




\begin{tabular}{|c|c|c|c|c|c|c|c|c|c|c|c|}
\hline Test Date & Location & $\begin{array}{c}\text { Test } \\
\text { Condition }\end{array}$ & $\begin{array}{l}\text { Fish } \\
\text { ID }\end{array}$ & $\begin{array}{c}\text { Tag } \\
\text { Number }\end{array}$ & $\begin{array}{l}\text { Deployment } \\
\text { Time }\end{array}$ & $\begin{array}{l}\text { Recovery } \\
\text { Time }\end{array}$ & File Name & $\begin{array}{l}\text { Gate } \\
\text { Setting } \\
\text { (ft) }\end{array}$ & $\begin{array}{c}\text { Forebay } \\
\text { Elevation } \\
\text { (ft) }\end{array}$ & $\begin{array}{l}\text { Tailwater } \\
\text { Elevation } \\
\text { (ft) }\end{array}$ & Head \\
\hline \multirow[t]{14}{*}{$7 / 19 / 2009$} & SB6 & $1.5 \mathrm{ft}$ & 711 & 8821 & 8:09 & $8: 23$ & f711_SB6_1_1 & 1.5 & 1559.61 & 1200.30 & 359.31 \\
\hline & & & 106 & 8881 & $8: 13$ & 8:18 & f106_SB6_1_2 & 1.5 & 1559.61 & 1200.30 & 359.31 \\
\hline & & & 114 & 8931 & $8: 51$ & 9:08 & f114_SB6_1_3 & 1.5 & 1559.61 & 1200.30 & 359.31 \\
\hline & & & 119 & 8831 & $8: 56$ & 9:08 & f119_SB6_1_4 & 1.5 & 1559.61 & 1200.30 & 359.31 \\
\hline & & & 661 & 8911 & $9: 25$ & $9: 40$ & f661_SB6_1_6 & 1.5 & 1559.61 & 1201.40 & 359.21 \\
\hline & & & 722 & 8841 & $9: 29$ & $9: 40$ & f722_SB6_1_5 & 1.5 & 1559.61 & 1201.40 & 359.21 \\
\hline & Control & SB6 low & 109 & 8131 & 10:04 & $10: 10$ & f109_Control_L2_1 & 1.5 & 1559.61 & 1202.00 & 357.61 \\
\hline & SB3 & $3.5 \mathrm{ft}$ & 101 & 8870 & 10:45 & $10: 51$ & f101_SB3_3_1 & 3.5 & 1559.61 & 1202.00 & 357.61 \\
\hline & & & 103 & 8864 & 10:49 & 10:55 & f103_SB3_3_2 & 3.5 & 1559.61 & 1202.00 & 357.61 \\
\hline & & & 106 & 8881 & 11:35 & 11:52 & f106_SB3_3_3 & 3.5 & 1559.61 & 1202.10 & 357.51 \\
\hline & & & 114 & 8931 & 11:40 & 11:52 & ------- & & & & \\
\hline & & & 119 & 8111 & $12: 18$ & $12: 23$ & f119_SB3_3_4 & 3.5 & 1559.58 & 1200.50 & 359.08 \\
\hline & & & 722 & 8841 & $12: 23$ & $12: 29$ & f722_SB3_3_5 & 3.5 & 1559.58 & 1200.50 & 359.08 \\
\hline & Control & SB6 high & 711 & 8821 & 13:17 & $13: 25$ & f711_Control_H2_1 & 3.5 & 1559.57 & 1200.30 & 359.27 \\
\hline \multirow[t]{5}{*}{$7 / 20 / 2009$} & SB3 & $3.5 \mathrm{ft}$ & 106 & 8881 & $7: 39$ & $7: 53$ & ------- & & 1559.30 & 1200.20 & 359.10 \\
\hline & & & 661 & 8131 & $7: 45$ & $7: 57$ & ------ & & 1559.30 & 1200.20 & 359.10 \\
\hline & & & 711 & 8821 & $8: 33$ & $8: 40$ & f711_SB3_3_6 & 3.5 & 1559.30 & 1201.40 & 357.90 \\
\hline & & & 119 & 8111 & 8:39 & $8: 46$ & f119_SB3_3_7 & 3.5 & 1559.30 & 1201.40 & 357.90 \\
\hline & Control & SB6 high & 103 & 8864 & 10:02 & $10: 21$ & f103_control_H2_2 & 3.5 & 1559.26 & 1200.70 & 358.56 \\
\hline
\end{tabular}




\begin{tabular}{|c|c|c|c|c|c|c|c|c|c|}
\hline Test Date & File Name & $\begin{array}{c}\text { Spillbay } 6 \\
\text { (cfs) }\end{array}$ & $\begin{array}{c}\text { Spillbay } 3 \\
\text { (cfs) }\end{array}$ & $\begin{array}{c}\text { Gage } \\
\text { Counter } \\
\text { SB } 6 \\
\end{array}$ & $\begin{array}{c}\text { Gage } \\
\text { Counter } \\
\text { SB } 3 \\
\end{array}$ & $\begin{array}{c}\text { Number of } \\
\text { Turbines } \\
\text { Operating }\end{array}$ & $\begin{array}{c}\text { Total } \\
\text { Powerhouse } \\
\text { flow (cfs) }\end{array}$ & $\begin{array}{l}\text { Total Project } \\
\text { Flow (cfs)* }\end{array}$ & $\begin{array}{c}\text { Approximate } \\
\text { Velocity at Plunge }\end{array}$ \\
\hline \multirow[t]{14}{*}{$7 / 19 / 2009$} & f711_SB6_1_1 & 1560 & 0 & 36 & 0 & 0 & 0 & 1560 & 152.05552 \\
\hline & f106_SB6_1_2 & 1560 & 0 & 36 & 0 & 0 & 0 & 1560 & 152.05552 \\
\hline & f114_SB6_1_3 & 1560 & 0 & 36 & 0 & 0 & 0 & 1560 & 152.05552 \\
\hline & f119_SB6_1_4 & 1560 & 0 & 36 & 0 & 0 & 0 & 1560 & 152.05552 \\
\hline & f661_SB6_1_6 & 1560 & 0 & 36 & 0 & 0 & 0 & 1560 & 151.82258 \\
\hline & f722_SB6_1_5 & 1560 & 0 & 36 & 0 & 0 & 0 & 1560 & 151.82258 \\
\hline & f109_Control_L2_1 & 1560 & 0 & 36 & 0 & 0 & 0 & 1560 & \\
\hline & f101_SB3_3_1 & 460 & 2938 & 11 & 70 & 0 & 0 & 3398 & 151.69538 \\
\hline & f103_SB3_3_2 & 460 & 2938 & 11 & 70 & 0 & 0 & 3398 & 151.69538 \\
\hline & f106_SB3_3_3 & 460 & 2938 & 11 & 70 & 0 & 0 & 3398 & 151.67417 \\
\hline & ------- & & & & & & & & \\
\hline & f119_SB3_3_4 & 460 & 2938 & 11 & 70 & 0 & 0 & 3398 & 152.00684 \\
\hline & f722_SB3_3_5 & 460 & 2938 & 11 & 70 & 0 & 0 & 3398 & 152.00684 \\
\hline & f711_Control_H2_1 & 3008 & 0 & 70 & 0 & 0 & 0 & 3008 & \\
\hline \multirow[t]{5}{*}{ 7/20/2009 } & ------- & 460 & 2858 & 11 & 70 & 0 & 0 & 3318 & 152.01107 \\
\hline & ------- & 460 & 2858 & 11 & 70 & 0 & 0 & 3318 & 152.01107 \\
\hline & f711_SB3_3_6 & 460 & 2858 & 11 & 70 & 0 & 0 & 3318 & 151.75688 \\
\hline & f119_SB3_3_7 & 460 & 2858 & 11 & 70 & 0 & 0 & 3318 & 151.75688 \\
\hline & f103_control_H2_2 & 2925 & 0 & 70 & 0 & 0 & 0 & 2925 & \\
\hline
\end{tabular}




\begin{tabular}{|c|c|c|c|c|c|c|c|c|c|c|c|}
\hline Test Date & Location & $\begin{array}{c}\text { Test } \\
\text { Condition } \\
\end{array}$ & $\begin{array}{c}\text { Fish } \\
\text { ID }\end{array}$ & $\begin{array}{c}\text { Tag } \\
\text { Number }\end{array}$ & $\begin{array}{c}\text { Deployment } \\
\text { Time }\end{array}$ & $\begin{array}{c}\text { Recovery } \\
\text { Time }\end{array}$ & File Name & $\begin{array}{l}\text { Gate } \\
\text { Setting } \\
\text { (ft) }\end{array}$ & $\begin{array}{c}\text { Forebay } \\
\text { Elevation } \\
(\mathrm{ft})\end{array}$ & $\begin{array}{c}\text { Tailwater } \\
\text { Elevation } \\
(\mathrm{ft})\end{array}$ & Head \\
\hline \multirow[t]{7}{*}{$7 / 20 / 2009$} & SB6 & $1.5 \mathrm{ft}$ & 722 & 8841 & $10: 55$ & 11:06 & f722_SB6_1_7 & 1.5 & 1559.25 & 1201.20 & 358.05 \\
\hline & & & 102 & 8271 & $10: 59$ & 11:04 & f102_SB6_1_8 & 1.5 & 1559.25 & 1201.20 & 358.05 \\
\hline & & & 101 & 8870 & $11: 32$ & 11:36 & f101_SB6_1_9 & 1.5 & 1559.25 & 1201.20 & 358.05 \\
\hline & & & 109 & 8131 & $11: 36$ & 11:43 & f109_SB6_1_10 & 1.5 & 1559.25 & 1201.20 & 358.05 \\
\hline & & & 711 & 8821 & 12:08 & $12: 11$ & f711_SB6_1_11 & 1.5 & 1559.24 & 1200.30 & 358.94 \\
\hline & & & 119 & 8111 & 12:14 & $12: 22$ & f119_SB6_1_12 & 1.5 & 1559.24 & 1200.30 & 358.94 \\
\hline & Control & SB6 low & 103 & 8864 & $13: 27$ & 13:41 & f103_control_L2_2 & 1.5 & 1559.24 & 1200.30 & 358.94 \\
\hline \multirow[t]{7}{*}{$7 / 21 / 2009$} & SB6 & $1.5 \mathrm{ft}$ & 109 & 8131 & 8:03 & $8: 16$ & f109_SB6_1_12 & 1.5 & 1559.11 & 1200.90 & 358.21 \\
\hline & & & 101 & 8870 & $8: 10$ & $8: 18$ & f101_SB6_1_13 & 1.5 & 1559.11 & 1200.90 & 358.21 \\
\hline & & & 722 & 8841 & $8: 46$ & 9:03 & f722_SB6_1_15 & 1.5 & 1559.11 & 1200.90 & 358.21 \\
\hline & & & 711 & 8821 & 8:54 & $8: 57$ & f711_SB6_1_16 & 1.5 & 1559.11 & 1200.90 & 358.21 \\
\hline & & & 103 & 8864 & 9:41 & 9:54 & f103_SB6_1_17 & 1.5 & 1559.11 & 1200.90 & 358.21 \\
\hline & & & 119 & 8111 & $9: 49$ & 9:52 & ------- & & 1559.11 & 1200.90 & 358.21 \\
\hline & Control & SB6 low & 109 & 8131 & $10: 32$ & 10:41 & f109_control_L2_3 & 1.5 & 1559.10 & 1201.00 & 358.10 \\
\hline
\end{tabular}




\begin{tabular}{|c|c|c|c|c|c|c|c|c|c|}
\hline Test Date & File Name & $\begin{array}{l}\text { Spillbay } 6 \\
\text { (cfs) }\end{array}$ & $\begin{array}{c}\text { Spillbay } 3 \\
\text { (cfs) }\end{array}$ & $\begin{array}{c}\text { Gage } \\
\text { Counter } \\
\text { SB } 6 \\
\end{array}$ & $\begin{array}{c}\text { Gage } \\
\text { Counter } \\
\text { SB } 3 \\
\end{array}$ & $\begin{array}{c}\text { Number of } \\
\text { Turbines } \\
\text { Operating }\end{array}$ & $\begin{array}{c}\text { Total } \\
\text { Powerhouse } \\
\text { flow (cfs) }\end{array}$ & $\begin{array}{c}\text { Total } \\
\text { Project Flow } \\
\text { (cfs) }{ }^{\left({ }^{2}\right)}\end{array}$ & $\begin{array}{c}\text { Approximate } \\
\text { Velocity at Plunge }\end{array}$ \\
\hline \multirow[t]{7}{*}{$7 / 20 / 2009$} & f722_SB6_1_7 & 1559 & 0 & 36 & 0 & 0 & 0 & 1559 & 151.78867 \\
\hline & f102_SB6_1_8 & 1559 & 0 & 36 & 0 & 0 & 0 & 1559 & 151.78867 \\
\hline & f101_SB6_1_9 & 1559 & 0 & 36 & 0 & 0 & 0 & 1555 & 151.78867 \\
\hline & f109_SB6_1_10 & 1559 & 0 & 36 & 0 & 0 & 0 & 1555 & 151.78867 \\
\hline & f711_SB6_1_11 & 1559 & 0 & 36 & 0 & 0 & 0 & 1559 & 151.97721 \\
\hline & f119_SB6_1_12 & 1559 & 0 & 36 & 0 & 0 & 0 & 1559 & 151.97721 \\
\hline & f103_control_L2_2 & 1559 & 0 & 36 & 0 & 0 & 0 & 1559 & \\
\hline \multirow[t]{7}{*}{$7 / 21 / 2009$} & f109_SB6_1_12 & 1559 & 0 & 36 & 0 & 0 & 0 & 1559 & 151.82258 \\
\hline & f101_SB6_1_13 & 1559 & 0 & 36 & 0 & 0 & 0 & 1559 & 151.82258 \\
\hline & f722_SB6_1_15 & 1559 & 0 & 36 & 0 & 0 & 0 & 1559 & 151.82258 \\
\hline & f711_SB6_1_16 & 1559 & 0 & 36 & 0 & 0 & 0 & 1559 & 151.82258 \\
\hline & f103_SB6_1_17 & 1559 & 0 & 36 & 0 & 0 & 0 & 1559 & 151.82258 \\
\hline & ------- & 1559 & 0 & 36 & 0 & 0 & 0 & 1559 & 151.82258 \\
\hline & f109_control_L2_3 & 1559 & 0 & 36 & 0 & 0 & 0 & 1559 & \\
\hline
\end{tabular}

(a) Readings taken prior to the close of spillgate. 


\section{Appendix B}

\section{Data Summary Tables for Each Sensor Fish Release}




\begin{tabular}{|c|c|c|c|c|c|}
\hline File & $\begin{array}{c}\text { Time } \\
\text { (s) }\end{array}$ & $\begin{array}{c}\text { AdjTime } \\
\text { (s) }\end{array}$ & $\begin{array}{c}\text { Acceleration } \\
\text { Magnitude (g) }\end{array}$ & Event Type & Location \\
\hline \multirow[t]{5}{*}{ f114_SB3_PT1 } & 10.063 & 0.612 & 156.2 & strike & chute \\
\hline & 10.9235 & 1.4725 & 152.3 & strike & chute \\
\hline & 12.484 & 3.033 & 139.9 & strike & chute \\
\hline & 10.3085 & 0.8575 & 135.5 & strike & chute \\
\hline & 13.5675 & 4.1165 & 105.2 & strike & chute \\
\hline \multirow[t]{2}{*}{ f725_SB3_pt2 } & 19.159 & 5.692 & 111.4 & strike & chute \\
\hline & 15.178 & 1.711 & 104.3 & strike & chute \\
\hline \multirow[t]{9}{*}{ f725_SB3_1_1 } & 10.6285 & 1.6995 & 152.3 & strike & chute \\
\hline & 12.5755 & 3.6465 & 141.6 & strike & chute \\
\hline & 14.9955 & 6.0665 & 140.7 & strike & chute \\
\hline & 13.135 & 4.206 & 136.3 & strike & chute \\
\hline & 12.1365 & 3.2075 & 135.1 & strike & chute \\
\hline & 14.801 & 5.872 & 109.1 & strike & chute \\
\hline & 15.367 & 6.438 & 109.4 & strike & $\mathrm{sb} / \mathrm{tr}$ \\
\hline & 15.504 & 6.575 & 106.9 & strike & $\mathrm{sb} / \mathrm{tr}$ \\
\hline & 12.3075 & 3.3785 & 106.1 & strike & chute \\
\hline \multirow[t]{7}{*}{ f101_SB3_1_2 } & 11.0475 & 1.8175 & 157 & strike & chute \\
\hline & 16.0125 & 6.7825 & 151.7 & strike & $\mathrm{sb} / \mathrm{tr}$ \\
\hline & 15.1805 & 5.9505 & 133.5 & strike & chute \\
\hline & 12.354 & 3.124 & 123.9 & strike & chute \\
\hline & 10.775 & 1.545 & 116.1 & strike & chute \\
\hline & 15.2085 & 5.9785 & 111.3 & strike & chute \\
\hline & 12.783 & 3.553 & 110.5 & strike & chute \\
\hline f722_SB3_1_3 & 11.722 & 3.447 & 146.4 & strike & chute \\
\hline \multirow[t]{11}{*}{ f711_SB3_1_4 } & 12.034 & 4.0245 & 204.2 & strike & chute \\
\hline & 12.23 & 4.2205 & 178.8 & strike & chute \\
\hline & 14.3065 & 6.297 & 138.2 & strike & $\mathrm{sb} / \mathrm{tr}$ \\
\hline & 14.9685 & 6.959 & 134.6 & strike & $\mathrm{sb} / \mathrm{tr}$ \\
\hline & 13.266 & 5.2565 & 130.5 & strike & chute \\
\hline & 12.3365 & 4.327 & 126.5 & strike & chute \\
\hline & 14.1525 & 6.143 & 121 & shear & $\mathrm{sb} / \mathrm{tr}$ \\
\hline & 10.69 & 2.6805 & 117.6 & strike & chute \\
\hline & 11.267 & 3.2575 & 112.6 & strike & chute \\
\hline & 10.347 & 2.3375 & 110.6 & strike & chute \\
\hline & 13.246 & 5.2365 & 107.3 & strike & chute \\
\hline \multirow[t]{3}{*}{ f722_SB3_1_5 } & 14.0815 & 5.2155 & 126.4 & strike & chute \\
\hline & 12.0615 & 3.1955 & 118 & strike & chute \\
\hline & 12.6175 & 3.7515 & 103.8 & strike & chute \\
\hline \multirow[t]{3}{*}{ f101_SB3_1_6 } & 13.644 & 2.05 & 130.5 & strike & chute \\
\hline & 15.456 & 3.862 & 114.3 & strike & chute \\
\hline & 15.335 & 3.741 & 106.6 & strike & chute \\
\hline \multirow[t]{5}{*}{ f711_SB3_1_7 } & 10.7705 & 1.7725 & 156.5 & strike & chute \\
\hline & 10.0765 & 1.0785 & 119.9 & strike & chute \\
\hline & 10.241 & 1.243 & 116.9 & strike & chute \\
\hline & 15.654 & 6.656 & 113.3 & strike & $\mathrm{sb} / \mathrm{tr}$ \\
\hline & 12.2065 & 3.2085 & 108.4 & strike & chute \\
\hline \multirow[t]{2}{*}{ f661_SB3_1_8 } & 15.3265 & 7.2305 & 163.2 & strike & $\mathrm{sb} / \mathrm{tr}$ \\
\hline & 9.509 & 1.413 & 150.1 & strike & chute \\
\hline
\end{tabular}




\begin{tabular}{|c|c|c|c|c|c|}
\hline File & $\begin{array}{c}\text { Time } \\
(\mathrm{s})\end{array}$ & $\begin{array}{l}\text { AdjTime } \\
\text { (s) }\end{array}$ & $\begin{array}{c}\text { Acceleration } \\
\text { Magnitude (g) }\end{array}$ & Event Type & Location \\
\hline & 14.33 & 6.234 & 142.3 & strike & chute \\
\hline & 11.041 & 2.945 & 127 & strike & chute \\
\hline & 11.22 & 3.124 & 111.7 & strike & chute \\
\hline & 11.883 & 3.787 & 105.5 & strike & chute \\
\hline f116_SB3_1_9 & 16.346 & 4.88 & 96.8 & strike & chute \\
\hline \multirow[t]{5}{*}{ f114_SB3_1_10 } & 11.018 & 2.1855 & 166.3 & strike & chute \\
\hline & 15.6865 & 6.854 & 123.3 & strike & $\mathrm{sb} / \mathrm{tr}$ \\
\hline & 15.2265 & 6.394 & 123.2 & strike & chute \\
\hline & 12.871 & 4.0385 & 114.9 & strike & chute \\
\hline & 11.305 & 2.4725 & 106 & strike & chute \\
\hline \multirow[t]{9}{*}{ f103_SB3_1_11 } & 12.5 & 4.886 & 201.5 & strike & chute \\
\hline & 9.381 & 1.767 & 170.4 & strike & chute \\
\hline & 14.4595 & 6.8455 & 154.5 & strike & $\mathrm{sb} / \mathrm{tr}$ \\
\hline & 11.3605 & 3.7465 & 132.1 & strike & chute \\
\hline & 15.3 & 7.686 & 130.6 & strike & $\mathrm{sb} / \mathrm{tr}$ \\
\hline & 14.226 & 6.612 & 116 & strike & $\mathrm{sb} / \mathrm{tr}$ \\
\hline & 10.402 & 2.788 & 105.9 & strike & chute \\
\hline & 10.6245 & 3.0105 & 104.8 & strike & chute \\
\hline & 14.387 & 6.773 & 95.8 & shear & $\mathrm{sb} / \mathrm{tr}$ \\
\hline \multirow[t]{7}{*}{ f109_SB3_1_12 } & 13.073 & 3.8925 & 131.8 & strike & chute \\
\hline & 10.41 & 1.2295 & 129.7 & strike & chute \\
\hline & 10.513 & 1.3325 & 128.4 & strike & chute \\
\hline & 11.1385 & 1.958 & 123.5 & strike & chute \\
\hline & 10.278 & 1.0975 & 122.4 & strike & chute \\
\hline & 16.008 & 6.8275 & 117.8 & strike & $\mathrm{sb} / \mathrm{tr}$ \\
\hline & 12.7445 & 3.564 & 116.8 & strike & chute \\
\hline \multirow{6}{*}{ f114_SB3_1_13 } & 13.6015 & 4.8625 & 168.8 & strike & chute \\
\hline & 11.228 & 2.489 & 152.1 & strike & chute \\
\hline & 15.7915 & 7.0525 & 124.5 & strike & $\mathrm{sb} / \mathrm{tr}$ \\
\hline & 10.249 & 1.51 & 107.4 & strike & chute \\
\hline & 13.9175 & 5.1785 & 98.8 & strike & chute \\
\hline & 11.451 & 2.712 & 97.8 & strike & chute \\
\hline f661_SB3_1_14 & 11.3185 & 3.647 & 115.1 & strike & chute \\
\hline \multirow[t]{3}{*}{ f711_SB3_1_15 } & 8.392 & 2.211 & 189.8 & strike & chute \\
\hline & 8.8025 & 2.6215 & 110.2 & strike & chute \\
\hline & 7.9725 & 1.7915 & 103.2 & strike & chute \\
\hline \multirow[t]{4}{*}{ f722_SB3_1_16 } & 13.9095 & 2.9255 & 161.6 & strike & chute \\
\hline & 18.0415 & 7.0575 & 131.6 & strike & $\mathrm{sb} / \mathrm{tr}$ \\
\hline & 11.71 & 0.726 & 123.2 & strike & chute \\
\hline & 15.262 & 4.278 & 115 & strike & chute \\
\hline \multirow{5}{*}{ f106_SB3_1_17 } & 14.16 & 3.0535 & 178.2 & strike & chute \\
\hline & 12.7175 & 1.611 & 141.5 & strike & chute \\
\hline & 12.5395 & 1.433 & 136.8 & strike & chute \\
\hline & 12.3345 & 1.228 & 112.1 & strike & chute \\
\hline & 16.8645 & 5.758 & 104.8 & strike & chute \\
\hline \multirow[t]{3}{*}{ f119_SB3_1_18 } & 10.5185 & 3.1155 & 190.8 & strike & chute \\
\hline & 9.06 & 1.657 & 183.9 & strike & chute \\
\hline & 9.8905 & 2.4875 & 97.5 & strike & chute \\
\hline
\end{tabular}




\begin{tabular}{|c|c|c|c|c|c|}
\hline File & $\begin{array}{c}\text { Time } \\
(\mathrm{s})\end{array}$ & $\begin{array}{l}\text { AdjTime } \\
\text { (s) }\end{array}$ & $\begin{array}{l}\text { Acceleration } \\
\text { Magnitude (g) }\end{array}$ & Event Type & Location \\
\hline \multirow[t]{7}{*}{ f103_SB3_1_19 } & 14.4565 & 4.55 & 151.3 & strike & chute \\
\hline & 12.6835 & 2.777 & 145.7 & strike & chute \\
\hline & 13.6345 & 3.728 & 120.2 & strike & chute \\
\hline & 14.5925 & 4.686 & 112.9 & strike & chute \\
\hline & 18.0745 & 8.168 & 105.7 & strike & $\mathrm{sb} / \mathrm{tr}$ \\
\hline & 16.3 & 6.3935 & 101.3 & strike & chute \\
\hline & 12.5135 & 2.607 & 98.6 & strike & chute \\
\hline \multirow[t]{2}{*}{ f661_SB3_1_20 } & 30.3315 & 6.1875 & 139.7 & strike & chute \\
\hline & 29.386 & 5.242 & 137.5 & strike & chute \\
\hline \multirow[t]{6}{*}{ f109_SB3_1_21 } & 12.4665 & 1.856 & 156 & strike & chute \\
\hline & 17.311 & 6.7005 & 141.7 & strike & $\mathrm{sb} / \mathrm{tr}$ \\
\hline & 14.3785 & 3.768 & 129 & strike & chute \\
\hline & 13.1895 & 2.579 & 118 & strike & chute \\
\hline & 13.515 & 2.9045 & 115.6 & strike & chute \\
\hline & 12.5585 & 1.948 & 114.3 & strike & chute \\
\hline \multirow[t]{10}{*}{ f711_SB3_1_22 } & 22.4025 & 6.6675 & 161.7 & strike & $\mathrm{sb} / \mathrm{tr}$ \\
\hline & 17.8565 & 2.1215 & 154.5 & strike & chute \\
\hline & 17.622 & 1.887 & 129.8 & strike & chute \\
\hline & 18.7635 & 3.0285 & 121.2 & strike & chute \\
\hline & 24.0775 & 8.3425 & 118.8 & strike & $\mathrm{sb} / \mathrm{tr}$ \\
\hline & 23.652 & 7.917 & 114.8 & strike & $\mathrm{sb} / \mathrm{tr}$ \\
\hline & & & 129.35 & mean & \\
\hline & & & 123.3 & median & \\
\hline & & & 23.87 & SD & \\
\hline & & & 2.21 & SE & \\
\hline \multirow[t]{9}{*}{ f722_SB6_PT1 } & 16.251 & 0.583 & 153.2 & strike & chute \\
\hline & 17.882 & 2.214 & 139.1 & strike & chute \\
\hline & 21.369 & 5.701 & 128 & strike & chute \\
\hline & 16.925 & 1.257 & 124.6 & Strike & chute \\
\hline & 21.1595 & 5.4915 & 118.9 & strike & chute \\
\hline & 21.4275 & 5.7595 & 114.3 & strike & chute \\
\hline & 21.4945 & 5.8265 & 110.4 & strike & chute \\
\hline & 21.627 & 5.959 & 108.9 & strike & chute \\
\hline & 20.2575 & 4.5895 & 96.3 & strike & chute \\
\hline \multirow[t]{7}{*}{ F635_sb6_pt2 } & 22.5985 & 4.9655 & 172.4 & strike & chute \\
\hline & 18.9795 & 1.3465 & 148.8 & strike & chute \\
\hline & 21.6405 & 4.0075 & 131.1 & strike & chute \\
\hline & 23.3265 & 5.6935 & 110.9 & strike & chute \\
\hline & 24.6445 & 7.0115 & 110.7 & shear & $\mathrm{sb} / \mathrm{tr}$ \\
\hline & 19.35 & 1.717 & 107.3 & strike & chute \\
\hline & 22.1985 & 4.5655 & 103.2 & strike & chute \\
\hline \multirow[t]{5}{*}{ f117_SB6_3_1 } & 10.692 & 2.8545 & 165.4 & Strike & chute \\
\hline & 10.843 & 3.0055 & 155.8 & Strike & chute \\
\hline & 14.34 & 6.5025 & 118.3 & Strike & $\mathrm{sb} / \mathrm{tr}$ \\
\hline & 8.9105 & 1.073 & 103 & Strike & chute \\
\hline & 12.4125 & 4.575 & 99.9 & Strike & chute \\
\hline \multirow[t]{2}{*}{ f661_SB6_3_2 } & 11.9845 & 3.235 & 164.1 & Strike & chute \\
\hline & 13.9815 & 5.232 & 160.2 & Strike & chute \\
\hline
\end{tabular}




\begin{tabular}{|c|c|c|c|c|c|}
\hline File & $\begin{array}{c}\text { Time } \\
\text { (s) }\end{array}$ & $\begin{array}{l}\text { AdjTime } \\
\text { (s) }\end{array}$ & $\begin{array}{l}\text { Acceleration } \\
\text { Magnitude (g) }\end{array}$ & Event Type & Location \\
\hline \multirow{6}{*}{ f101_SB6_3_3 } & 15.0015 & 6.252 & 140.7 & Strike & end \\
\hline & 11.766 & 3.0165 & 134.3 & Strike & chute \\
\hline & 10.0165 & 1.267 & 130.7 & Strike & chute \\
\hline & 11.6535 & 2.904 & 116.3 & Strike & chute \\
\hline & 14.4405 & 6.261 & 128.8 & Strike & $\mathrm{sb} / \mathrm{tr}$ \\
\hline & 14.629 & 6.4495 & 111.5 & Strike & $\mathrm{sb} / \mathrm{tr}$ \\
\hline \multirow[t]{4}{*}{ f722_SB6_3_4 } & 9.465 & 0.7505 & 160.8 & Strike & chute \\
\hline & 12.688 & 3.9735 & 131.6 & Strike & chute \\
\hline & 11.446 & 2.7315 & 127.6 & strike & chute \\
\hline & 12.7545 & 4.04 & 118.6 & Strike & chute \\
\hline \multirow[t]{9}{*}{ f722_SB6_3_5 } & 14.7995 & 3.0235 & 185.2 & shear & chute \\
\hline & 13.016 & 1.24 & 136.7 & Strike & chute \\
\hline & 12.857 & 1.081 & 136.4 & Strike & chute \\
\hline & 19.289 & 7.513 & 134.5 & strike & $\mathrm{sb} / \mathrm{tr}$ \\
\hline & 16.1585 & 4.3825 & 129.2 & Strike & chute \\
\hline & 16.343 & 4.567 & 128.1 & strike & chute \\
\hline & 12.3705 & 0.5945 & 127 & strike & chute \\
\hline & 18.8845 & 7.1085 & 121.1 & Strike & $\mathrm{sb} / \mathrm{tr}$ \\
\hline & 13.0975 & 1.3215 & 107.7 & Strike & chute \\
\hline \multirow[t]{3}{*}{ f101_SB6_3_6 } & 14.1 & 5.8005 & 131.9 & Strike & $\mathrm{sb} / \mathrm{tr}$ \\
\hline & 14.065 & 5.7655 & 131.1 & strike & $\mathrm{sb} / \mathrm{tr}$ \\
\hline & 11.539 & 3.2395 & 99.7 & Strike & chute \\
\hline \multirow[t]{6}{*}{ f109_SB6_3_7 } & 14.2985 & 6.607 & 161.7 & shear & $\mathrm{sb} / \mathrm{tr}$ \\
\hline & 14.3205 & 6.629 & 159.4 & shear & $\mathrm{sb} / \mathrm{tr}$ \\
\hline & 9.128 & 1.4365 & 128.5 & Strike & chute \\
\hline & 8.681 & 0.9895 & 122.3 & Strike & chute \\
\hline & 10.7995 & 3.108 & 120 & Strike & chute \\
\hline & 8.6605 & 0.969 & 96.2 & strike & chute \\
\hline \multirow[t]{5}{*}{ f711_SB6_3_8 } & 12.4245 & 5.414 & 147.4 & Strike & chute \\
\hline & 12.057 & 5.0465 & 131.4 & Strike & chute \\
\hline & 8.6355 & 1.25 & 122.6 & Strike & chute \\
\hline & 10.5235 & 3.513 & 114.5 & Strike & chute \\
\hline & 8.357 & 1.3465 & 110.7 & Strike & chute \\
\hline \multirow[t]{4}{*}{ f661_SB6_3_9 } & 15.689 & 5.7425 & 129.8 & Strike & chute \\
\hline & 12.9335 & 2.987 & 117.8 & Strike & chute \\
\hline & 12.7815 & 2.835 & 116.1 & Strike & chute \\
\hline & 16.113 & 6.1665 & 96.7 & Strike & $\mathrm{sb} / \mathrm{tr}$ \\
\hline \multirow[t]{4}{*}{ f114_SB6_3_10 } & 10.8975 & 3.3735 & 172.5 & Strike & chute \\
\hline & 10.1845 & 2.6605 & 170.9 & Strike & chute \\
\hline & 13.5205 & 5.9965 & 129.8 & Strike & $\mathrm{sb} / \mathrm{tr}$ \\
\hline & 12.96 & 5.436 & 122.6 & Strike & chute \\
\hline \multirow[t]{6}{*}{ f103_SB6_3_11 } & 18.178 & 2.902 & 190.9 & Strike & chute \\
\hline & 18.061 & 2.785 & 153.5 & Strike & chute \\
\hline & 19.9505 & 4.6745 & 140.2 & Strike & chute \\
\hline & 29.922 & 14.646 & 111.6 & Strike & $\mathrm{sb} / \mathrm{tr}$ \\
\hline & 18.5405 & 3.2645 & 117.4 & Strike & chute \\
\hline & 21.416 & 6.14 & 97.1 & Strike & $\mathrm{sb} / \mathrm{tr}$ \\
\hline
\end{tabular}




\begin{tabular}{|c|c|c|c|c|c|}
\hline File & $\begin{array}{c}\text { Time } \\
(\mathrm{s})\end{array}$ & $\begin{array}{l}\text { AdjTime } \\
\text { (s) }\end{array}$ & $\begin{array}{c}\text { Acceleration } \\
\text { Magnitude (g) }\end{array}$ & Event Type & Location \\
\hline \multirow{8}{*}{ f114_SB6_3_12 } & 10.128 & 3.369 & 170.3 & Strike & chute \\
\hline & 8.662 & 1.903 & 166.2 & Strike & chute \\
\hline & 8.142 & 1.383 & 144.5 & Strike & chute \\
\hline & 8.1905 & 1.4315 & 121.9 & Strike & chute \\
\hline & 8.3765 & 1.6175 & 117.2 & Strike & chute \\
\hline & 8.738 & 1.979 & 114 & Strike & chute \\
\hline & 9.6955 & 2.9365 & 112.1 & Strike & chute \\
\hline & 9.909 & 3.15 & 107.4 & Strike & chute \\
\hline \multirow{11}{*}{ f661_SB6_3_13 } & 7.9125 & 0.8215 & 165.8 & strike & chute \\
\hline & 11.0675 & 3.9765 & 136.9 & Strike & chute \\
\hline & 13.7865 & 6.6955 & 127.6 & Strike & $\mathrm{sb} / \mathrm{tr}$ \\
\hline & 14.6995 & 7.6085 & 118.6 & Strike & $\mathrm{sb} / \mathrm{tr}$ \\
\hline & 8.289 & 1.198 & 118.5 & Strike & chute \\
\hline & 8.436 & 1.345 & 114.2 & Strike & chute \\
\hline & 7.6325 & 0.5415 & 111.1 & Strike & chute \\
\hline & 9.1735 & 2.0825 & 109.4 & Strike & chute \\
\hline & 12.6235 & 5.5325 & 105.9 & Strike & chute \\
\hline & 14.1595 & 7.0865 & 105.8 & Strike & $\mathrm{sb} / \mathrm{tr}$ \\
\hline & 8.052 & 0.961 & 102.7 & Strike & chute \\
\hline \multirow[t]{4}{*}{ f711_SB6_3_14 } & 15.725 & 3.1 & 160.1 & Strike & chute \\
\hline & 19.2 & 6.575 & 129.3 & Strike & $\mathrm{sb} / \mathrm{tr}$ \\
\hline & 17.2895 & 4.6645 & 123.8 & Strike & chute \\
\hline & 16.1355 & 3.5105 & 114.2 & Strike & chute \\
\hline \multirow[t]{2}{*}{ f722_SB6_3_15 } & 15.9125 & 8.3885 & 135 & Strike & $\mathrm{sb} / \mathrm{tr}$ \\
\hline & 12.778 & 5.254 & 103 & Strike & chute \\
\hline \multirow[t]{4}{*}{ f106_SB6_3_16 } & 13.7855 & 2.6515 & 169.5 & Strike & chute \\
\hline & 13.909 & 2.775 & 146.8 & Strike & chute \\
\hline & 14.564 & 3.43 & 140.4 & Strike & chute \\
\hline & 17.374 & 6.24 & 131.6 & shear & end \\
\hline f103_SB6_3_17 & 16.1135 & 6.0725 & 200 & Strike & chute \\
\hline \multicolumn{6}{|l|}{ f101_SB6_3_18 } \\
\hline \multirow[t]{5}{*}{ F104_SB6_3_19 } & 7.7205 & 0.54 & 145.8 & Strike & chute \\
\hline & 9.6165 & 2.436 & 121.3 & Strike & chute \\
\hline & 7.847 & 0.6665 & 116.8 & Strike & chute \\
\hline & 11.736 & 4.5555 & 113.7 & Strike & chute \\
\hline & 13.7655 & 6.585 & 107.1 & Strike & $\mathrm{sb} / \mathrm{tr}$ \\
\hline f109_SB6_3_20 & 15.889 & 5.9255 & 124.6 & Strike & $\mathrm{sb} / \mathrm{tr}$ \\
\hline \multirow[t]{3}{*}{ f102_SB6_3_21 } & 15.78 & 2.369 & 129.8 & Strike & chute \\
\hline & 19.866 & 6.455 & 122.5 & strike & $\mathrm{sb} / \mathrm{tr}$ \\
\hline & 19.8445 & 6.4335 & 119 & shear & $\mathrm{sb} / \mathrm{tr}$ \\
\hline \multirow{5}{*}{ f711_SB6_3_22 } & 11.266 & 2.487 & 155.2 & shear & chute \\
\hline & 14.9555 & 6.1765 & 150.8 & Strike & SB \\
\hline & 11.3365 & 2.5575 & 144.2 & Strike & chute \\
\hline & 13.4065 & 4.6275 & 143.5 & Strike & chute \\
\hline & 12.2815 & 3.5025 & 99.2 & Strike & chute \\
\hline \multirow[t]{3}{*}{ f114_SB6_3_23 } & 10.306 & 2.4325 & 150 & Strike & chute \\
\hline & 10.716 & 2.8425 & 104.8 & Strike & chute \\
\hline & 13.8195 & 5.946 & 100.6 & shear & $\mathrm{sb} / \mathrm{tr}$ \\
\hline
\end{tabular}




\begin{tabular}{|c|c|c|c|c|c|}
\hline File & $\begin{array}{c}\text { Time } \\
\text { (s) }\end{array}$ & $\begin{array}{l}\text { AdjTime } \\
\text { (s) }\end{array}$ & $\begin{array}{l}\text { Acceleration } \\
\text { Magnitude (g) }\end{array}$ & Event Type & Location \\
\hline \multirow[t]{19}{*}{ f119_SB6_3_24 } & 10.3805 & 2.745 & 206.3 & Strike & chute \\
\hline & 10.8795 & 3.244 & 197.8 & Strike & chute \\
\hline & 13.8775 & 6.242 & 183.7 & Strike & chute \\
\hline & 14.2555 & 6.62 & 153.2 & Strike & $\mathrm{sb} / \mathrm{tr}$ \\
\hline & 9.3075 & 1.672 & 152.7 & Strike & chute \\
\hline & 10.445 & 2.8095 & 139.7 & Strike & chute \\
\hline & 16.098 & 8.4625 & 138 & Strike & $\mathrm{sb} / \mathrm{tr}$ \\
\hline & 15.8475 & 8.212 & 134.4 & Strike & $\mathrm{sb} / \mathrm{tr}$ \\
\hline & 13.533 & 5.8975 & 124.7 & Strike & chute \\
\hline & 9.452 & 1.8165 & 123.5 & Strike & chute \\
\hline & 14.432 & 6.7965 & 122 & shear & $\mathrm{sb} / \mathrm{tr}$ \\
\hline & 15.77 & 8.1345 & 119.7 & Strike & $\mathrm{sb} / \mathrm{tr}$ \\
\hline & 10.3 & 2.6645 & 115.4 & Strike & chute \\
\hline & 9.7625 & 2.127 & 112.7 & Strike & chute \\
\hline & 13.503 & 5.8675 & 106.1 & Strike & chute \\
\hline & & & 131.05 & mean & \\
\hline & & & 127.3 & median & \\
\hline & & & 23.72 & STDEV & \\
\hline & & & 2.06 & SE & \\
\hline \multirow{8}{*}{ f101_SB3_3_1 } & 17.734 & 2.028 & 172.6 & strike & chute \\
\hline & 22.409 & 6.703 & 161 & strike & $\mathrm{sb} / \mathrm{tr}$ \\
\hline & 19.007 & 3.301 & 135.3 & strike & chute \\
\hline & 20.4405 & 4.7345 & 128.6 & strike & chute \\
\hline & 19.168 & 3.462 & 124.6 & strike & chute \\
\hline & 20.5355 & 4.8295 & 112.8 & strike & chute \\
\hline & 22.272 & 6.566 & 100.1 & strike & $\mathrm{sb} / \mathrm{tr}$ \\
\hline & 17.708 & 2.002 & 99.4 & strike & chute \\
\hline \multirow[t]{2}{*}{ f103_SB3_3_2 } & 17.1115 & 2.8175 & 221.3 & strike & chute \\
\hline & 17.985 & 3.691 & 96.7 & strike & chute \\
\hline \multirow[t]{8}{*}{ f106_SB3_3_3 } & 23.583 & 8.25 & 170.1 & strike & $\mathrm{sb} / \mathrm{tr}$ \\
\hline & 23.4265 & 8.0935 & 163.9 & shear & $\mathrm{sb} / \mathrm{tr}$ \\
\hline & 17.3865 & 2.0535 & 161.3 & strike & chute \\
\hline & 21.58 & 6.247 & 159.3 & shear & chute \\
\hline & 17.936 & 2.603 & 136.7 & strike & chute \\
\hline & 15.9105 & 0.5775 & 134.3 & strike & chute \\
\hline & 17.5575 & 2.2245 & 118.7 & strike & chute \\
\hline & 17.494 & 2.161 & 110.2 & strike & chute \\
\hline \multirow[t]{2}{*}{ f119_SB3_3_4 } & 22.114 & 3.066 & 176.9 & strike & chute \\
\hline & 19.7985 & 0.7505 & 142.4 & strike & chute \\
\hline \multirow[t]{5}{*}{ f722_SB3_3_5 } & 27.656 & 1.6545 & 144.2 & strike & chute \\
\hline & 28.2505 & 2.249 & 118.8 & strike & chute \\
\hline & 27.969 & 1.9675 & 109 & strike & chute \\
\hline & 29.431 & 3.4295 & 103.4 & strike & chute \\
\hline & 29.304 & 3.3025 & 98.6 & strike & chute \\
\hline \multirow[t]{4}{*}{ f711_SB3_3_6 } & 19.223 & 0.849 & 160.6 & strike & chute \\
\hline & 24.3395 & 5.9655 & 109.9 & strike & end \\
\hline & 24.5725 & 6.1985 & 102.1 & shear & $\mathrm{sb} / \mathrm{tr}$ \\
\hline & 22.4485 & 4.0745 & 96.7 & strike & chute \\
\hline
\end{tabular}




\begin{tabular}{|c|c|c|c|c|c|}
\hline File & $\begin{array}{c}\text { Time } \\
(\mathrm{s})\end{array}$ & $\begin{array}{l}\text { AdjTime } \\
\text { (s) }\end{array}$ & $\begin{array}{c}\text { Acceleration } \\
\text { Magnitude (g) }\end{array}$ & Event Type & Location \\
\hline \multirow[t]{12}{*}{ f119_SB3_3_7 } & 21.749 & 6.642 & 179.5 & strike & $\mathrm{sb} / \mathrm{tr}$ \\
\hline & 21.6885 & 6.5815 & 145.7 & strike & $\mathrm{sb} / \mathrm{tr}$ \\
\hline & 20.1825 & 5.0755 & 131.2 & strike & chute \\
\hline & 18.2915 & 3.1845 & 122.8 & strike & chute \\
\hline & 22.461 & 7.354 & 108.1 & strike & $\mathrm{sb} / \mathrm{tr}$ \\
\hline & 17.833 & 2.726 & 103.9 & strike & chute \\
\hline & 16.733 & 1.626 & 102.6 & strike & chute \\
\hline & 21.9675 & 6.8605 & 96.4 & strike & $\mathrm{sb} / \mathrm{tr}$ \\
\hline & & & 131.34 & mean & \\
\hline & & & 124.6 & median & \\
\hline & & & 30.44 & STDEV & \\
\hline & & & 5.00 & SE & \\
\hline \multirow[t]{5}{*}{ f711_SB6_1_1 } & 23.935 & 1.861 & 143.5 & strike & chute \\
\hline & 23.796 & 1.722 & 140.7 & strike & chute \\
\hline & 28.2805 & 6.2065 & 130.7 & strike & end \\
\hline & 29.595 & 7.521 & 110.6 & strike & $\mathrm{sb} / \mathrm{tr}$ \\
\hline & 27.7085 & 5.6345 & 110.1 & strike & chute \\
\hline \multirow[t]{4}{*}{ f106_SB6_1_2 } & 27.944 & 2.0815 & 131.2 & strike & chute \\
\hline & 27.6655 & 1.803 & 123.9 & strike & chute \\
\hline & 30.2215 & 4.359 & 123.5 & strike & chute \\
\hline & 30.8525 & 4.99 & 104.7 & strike & chute \\
\hline \multirow[t]{7}{*}{ f114_SB6_1_3 } & 16.069 & 2.7505 & 175.3 & strike & chute \\
\hline & 15.059 & 1.7405 & 164.6 & strike & chute \\
\hline & 15.134 & 1.8155 & 157.9 & strike & chute \\
\hline & 18.301 & 4.9825 & 141.1 & strike & chute \\
\hline & 18.087 & 4.7685 & 123.6 & strike & chute \\
\hline & 15.084 & 1.7655 & 115.9 & strike & chute \\
\hline & 15.0005 & 1.682 & 115.6 & strike & chute \\
\hline \multirow[t]{6}{*}{ f119_SB6_1_4 } & 28.7125 & 4.548 & 175.8 & strike & chute \\
\hline & 28.268 & 4.1035 & 124 & strike & chute \\
\hline & 25.845 & 1.6805 & 123.1 & strike & chute \\
\hline & 30.594 & 6.4295 & 112.5 & strike & $\mathrm{sb} / \mathrm{tr}$ \\
\hline & 26.8755 & 2.711 & 107.9 & strike & chute \\
\hline & 25.778 & 1.6135 & 103.1 & strike & chute \\
\hline \multirow[t]{7}{*}{ f722_SB6_1_5 } & 21.861 & 5.1175 & 131 & strike & chute \\
\hline & 23.302 & 6.5585 & 123.5 & strike & $\mathrm{sb} / \mathrm{tr}$ \\
\hline & 21.245 & 4.5015 & 115.5 & strike & chute \\
\hline & 22.714 & 5.9705 & 108.2 & strike & chute \\
\hline & 25.1225 & 8.379 & 100.7 & strike & $\mathrm{sb} / \mathrm{tr}$ \\
\hline & 20.761 & 4.0175 & 99.8 & strike & chute \\
\hline & 22.777 & 6.0335 & 99.7 & strike & chute \\
\hline \multirow[t]{3}{*}{ f661_SB6_1_6 } & 16.0875 & 6.7295 & 150.3 & strike & $\mathrm{sb} / \mathrm{tr}$ \\
\hline & 14.708 & 5.35 & 141.5 & strike & chute \\
\hline & 15.8415 & 6.4835 & 121 & strike & $\mathrm{sb} / \mathrm{tr}$ \\
\hline \multirow[t]{4}{*}{ f722_SB6_1_7 } & 19.5755 & 2.1235 & 171.5 & strike & chute \\
\hline & 24.2905 & 6.8385 & 151.6 & strike & $\mathrm{sb} / \mathrm{tr}$ \\
\hline & 23.7365 & 6.2845 & 147.3 & strike & chute \\
\hline & 22.749 & 5.297 & 138.8 & strike & chute \\
\hline
\end{tabular}




\begin{tabular}{|c|c|c|c|c|c|}
\hline File & $\begin{array}{l}\text { Time } \\
\text { (s) }\end{array}$ & $\begin{array}{l}\text { AdjTime } \\
\text { (s) }\end{array}$ & $\begin{array}{c}\text { Acceleration } \\
\text { Magnitude (g) }\end{array}$ & Event Type & Location \\
\hline \multirow{10}{*}{ f102_SB6_1_8 } & 24.3585 & 6.9065 & 120.6 & strike & $\mathrm{sb} / \mathrm{tr}$ \\
\hline & 22.592 & 5.14 & 98.7 & strike & chute \\
\hline & 19.9345 & 2.5405 & 179.4 & strike & chute \\
\hline & 19.2845 & 1.8905 & 165.1 & strike & chute \\
\hline & 21.819 & 4.425 & 151 & strike & chute \\
\hline & 23.573 & 6.179 & 139.9 & strike & chute \\
\hline & 19.061 & 1.667 & 128.4 & strike & chute \\
\hline & 19.682 & 2.288 & 120.5 & strike & chute \\
\hline & 18.648 & 1.254 & 114 & strike & chute \\
\hline & 19.5985 & 2.2045 & 117.1 & strike & chute \\
\hline \multirow{8}{*}{ f101_SB6_1_9 } & 19.9825 & 1.7395 & 147.2 & strike & chute \\
\hline & 20.6555 & 2.4125 & 138.8 & strike & chute \\
\hline & 22.723 & 4.48 & 126.7 & strike & chute \\
\hline & 26.14 & 7.897 & 122.9 & strike & $\mathrm{sb} / \mathrm{tr}$ \\
\hline & 26.2605 & 8.0175 & 118.2 & strike & $\mathrm{sb} / \mathrm{tr}$ \\
\hline & 22.4505 & 4.2075 & 116.2 & strike & chute \\
\hline & 20.9245 & 2.6815 & 115.6 & strike & chute \\
\hline & 25.029 & 6.786 & 110.8 & strike & $\mathrm{sb} / \mathrm{tr}$ \\
\hline \multirow[t]{9}{*}{ f109_SB6_1_10 } & 22.75 & 4.453 & 145.3 & strike & chute \\
\hline & 25.4355 & 7.1385 & 139.8 & strike & $\mathrm{sb} / \mathrm{tr}$ \\
\hline & 24.141 & 5.844 & 135.4 & strike & chute \\
\hline & 21.2675 & 2.9705 & 125.9 & strike & chute \\
\hline & 20.5435 & 2.247 & 120 & strike & chute \\
\hline & 20.3785 & 2.0815 & 115.4 & strike & chute \\
\hline & 19.4575 & 1.1605 & 113.7 & strike & chute \\
\hline & 22.2135 & 3.9165 & 103.8 & strike & chute \\
\hline & 25.462 & 7.165 & 95.6 & shear & $\mathrm{sb} / \mathrm{tr}$ \\
\hline \multirow[t]{7}{*}{ f711_SB6_1_11 } & 13.502 & 1.988 & 185.2 & strike & chute \\
\hline & 18.459 & 6.945 & 153.2 & strike & end \\
\hline & 12.1995 & 0.6855 & 148.9 & strike & chute \\
\hline & 12.0045 & 0.4905 & 143.8 & strike & chute \\
\hline & 12.455 & 0.941 & 130.8 & strike & chute \\
\hline & 13.7795 & 2.2655 & 130.4 & strike & chute \\
\hline & 16.965 & 5.451 & 122.6 & strike & chute \\
\hline \multirow[t]{6}{*}{ f119_SB6_1_12 } & 27.1065 & 2.9245 & 217.7 & strike & chute \\
\hline & 29.6485 & 5.4665 & 162 & strike & chute \\
\hline & 29.11 & 4.928 & 153.1 & strike & chute \\
\hline & 28.4295 & 4.2475 & 118.2 & strike & chute \\
\hline & 30.4225 & 6.2405 & 112.3 & strike & chute \\
\hline & 25.952 & 1.77 & 95.1 & strike & chute \\
\hline \multirow[t]{4}{*}{ f109_SB6_1_12 } & 26.1525 & 5.529 & 137.2 & strike & chute \\
\hline & 25.0245 & 4.401 & 118 & strike & chute \\
\hline & 26.252 & 5.6285 & 113.9 & strike & chute \\
\hline & 27.933 & 7.2095 & 95.6 & strike & $\mathrm{sb} / \mathrm{tr}$ \\
\hline \multirow[t]{4}{*}{ f101_SB6_1_13 } & 14.1545 & 2.4975 & 150.5 & strike & chute \\
\hline & 14.5415 & 2.8845 & 143.7 & strike & chute \\
\hline & 13.726 & 2.069 & 134.9 & strike & chute \\
\hline & 16.394 & 4.737 & 127.2 & strike & chute \\
\hline
\end{tabular}




\begin{tabular}{cllccc}
\hline File & $\begin{array}{c}\text { Time } \\
(\mathrm{s})\end{array}$ & $\begin{array}{c}\text { AdjTime } \\
(\mathrm{s})\end{array}$ & $\begin{array}{c}\text { Acceleration } \\
\text { Magnitude }(\mathrm{g})\end{array}$ & Event Type & Location \\
\hline & 13.345 & 1.688 & 118.2 & strike & chute \\
f722_SB6_1_15 & 19.3925 & 5.9765 & 116.8 & strike & chute \\
& 15.819 & 2.403 & 112.1 & strike & chute \\
f711_SB6_1_16 & 21.687 & 2.7805 & 151.5 & strike & chute \\
& 21.1025 & 2.196 & 131.1 & strike & chute \\
& 22.324 & 3.4175 & 123.3 & strike & chute \\
& 25.3305 & 6.424 & 116 & strike & end \\
& 24.904 & 5.9975 & 99.8 & strike & chute \\
f103_SB6_1_17 & 16.4955 & 4.5255 & 125.1 & strike & chute \\
& 14.0835 & 2.1135 & 123.2 & strike & chute \\
& 13.809 & 1.839 & 117.6 & strike & chute \\
& 18.9735 & 7.0035 & 103.6 & strike & sb/tr \\
& 18.01665 & 6.0465 & 96.8 & strike & chute \\
& & & 129.02 & mean & \\
& & & 123.5 & median & \\
& & & 22.41 & STDEV & SE \\
\hline
\end{tabular}


Appendix C

\section{Pressure and Acceleration Time Histories of Each Sensor Fish Release}




\section{Spillbay 3, 1.5-ft Tainter Gate Opening}


Spillbay 3, 1.5' Opening, Pre-Test F114
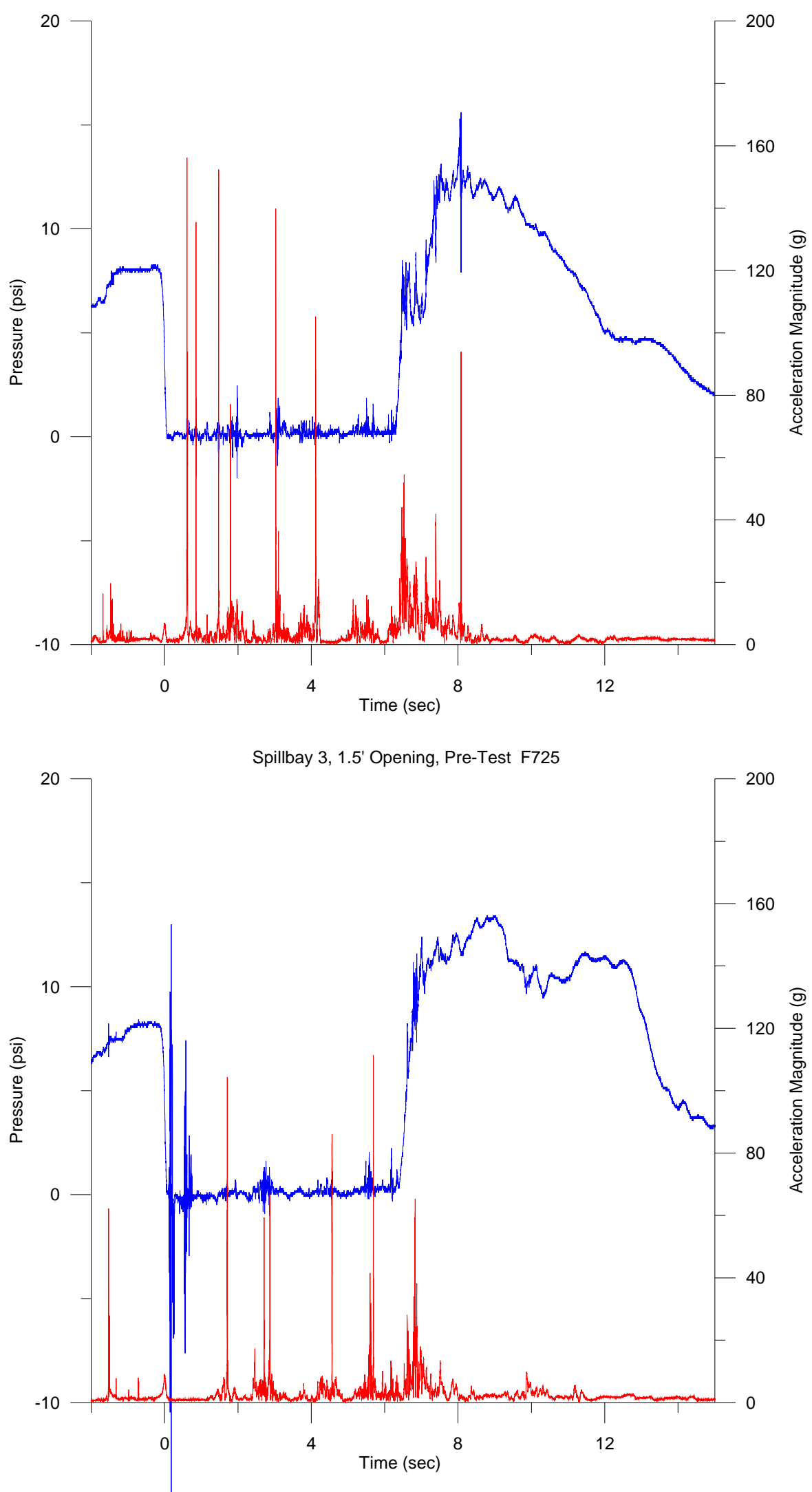

C.1 

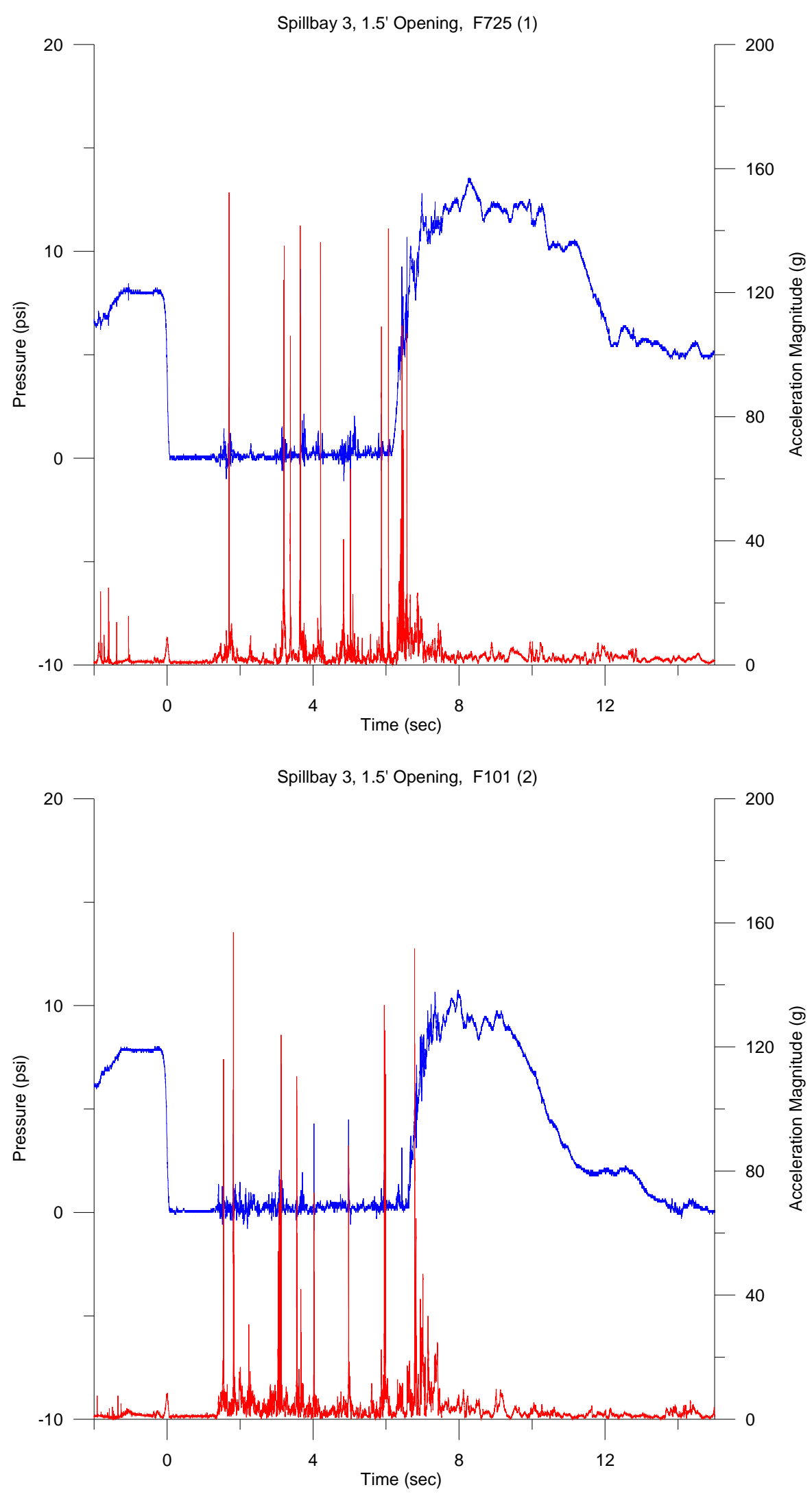

C. 2 

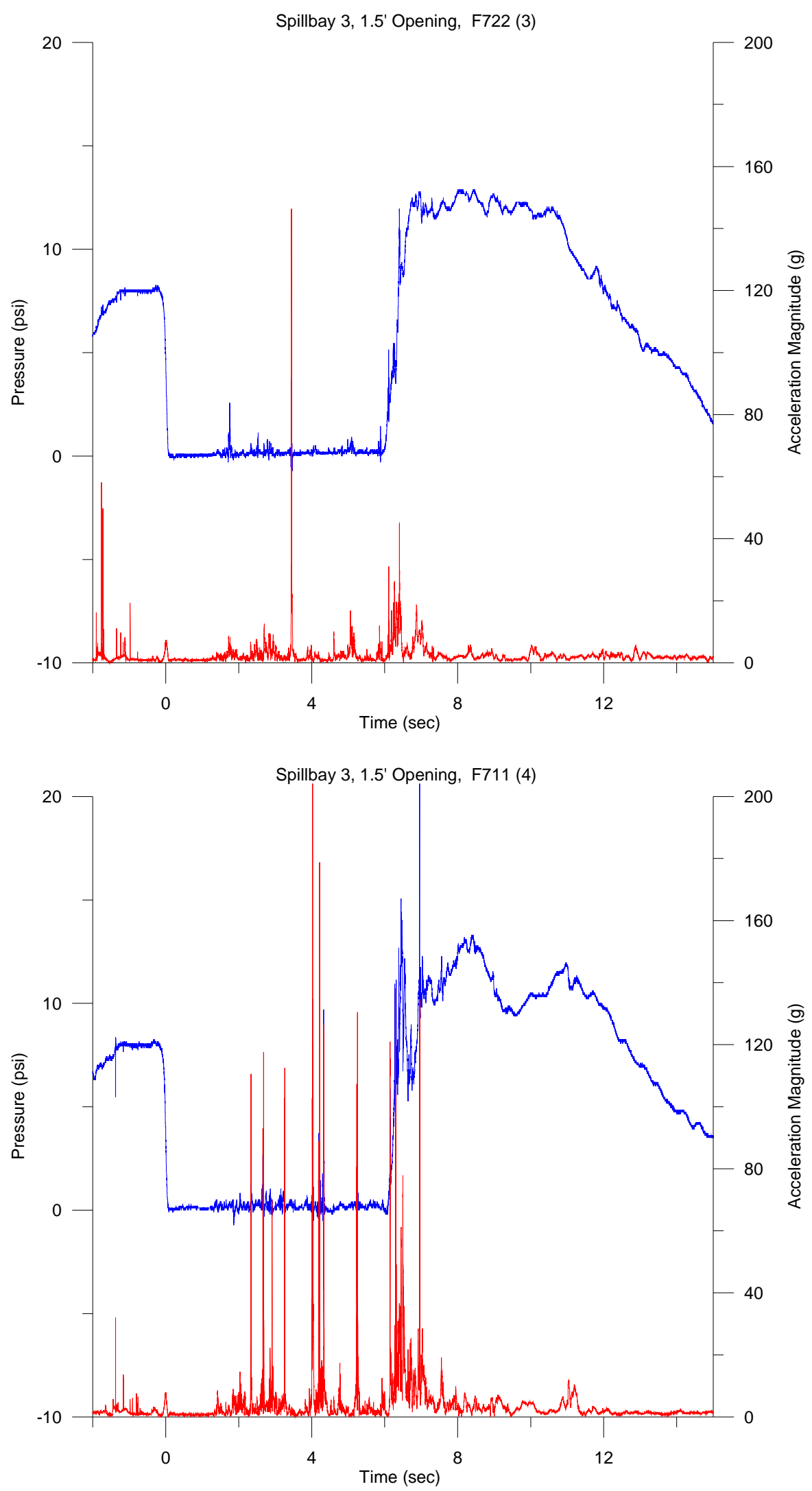

C. 3 

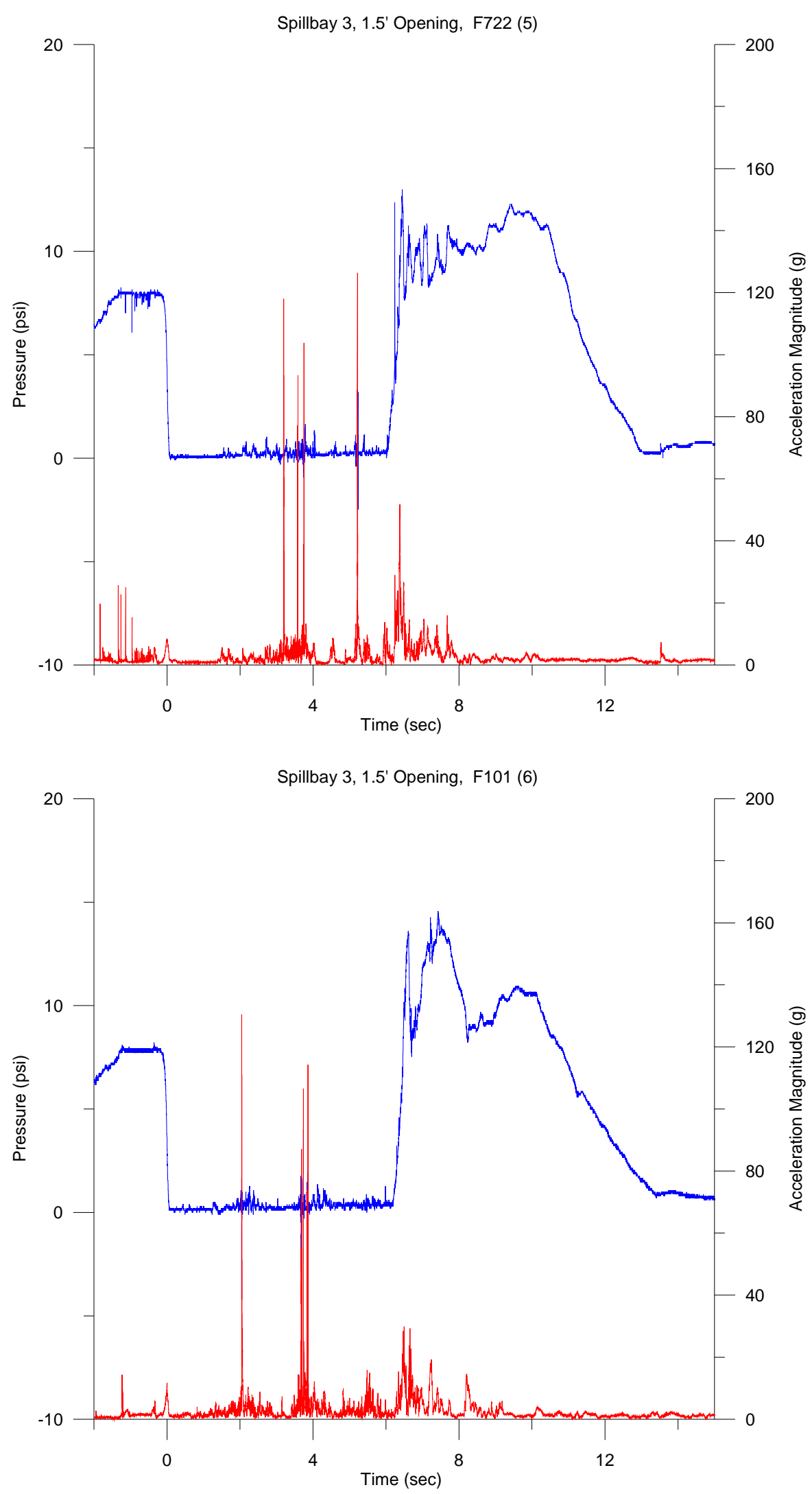

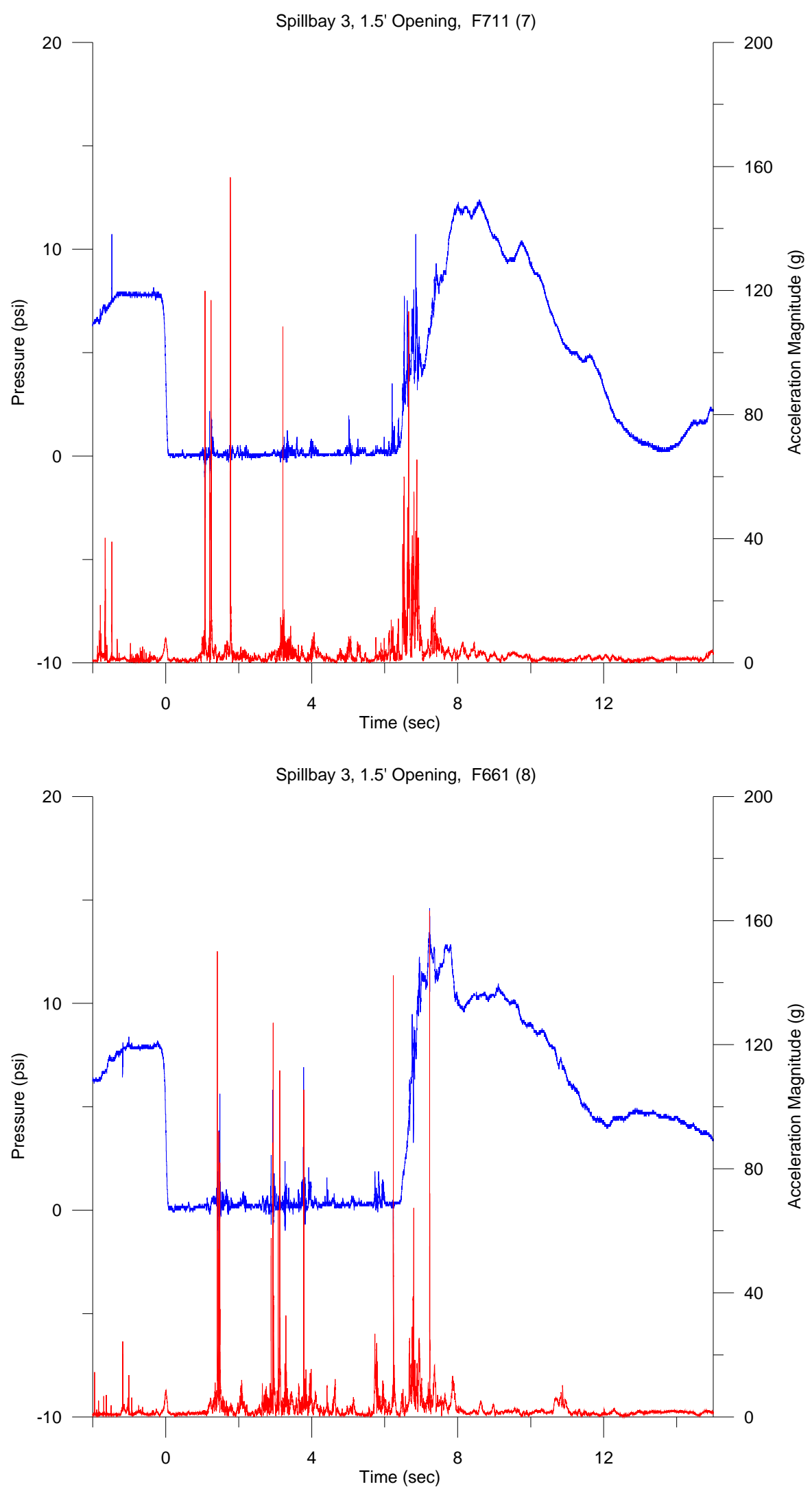

C. 5 

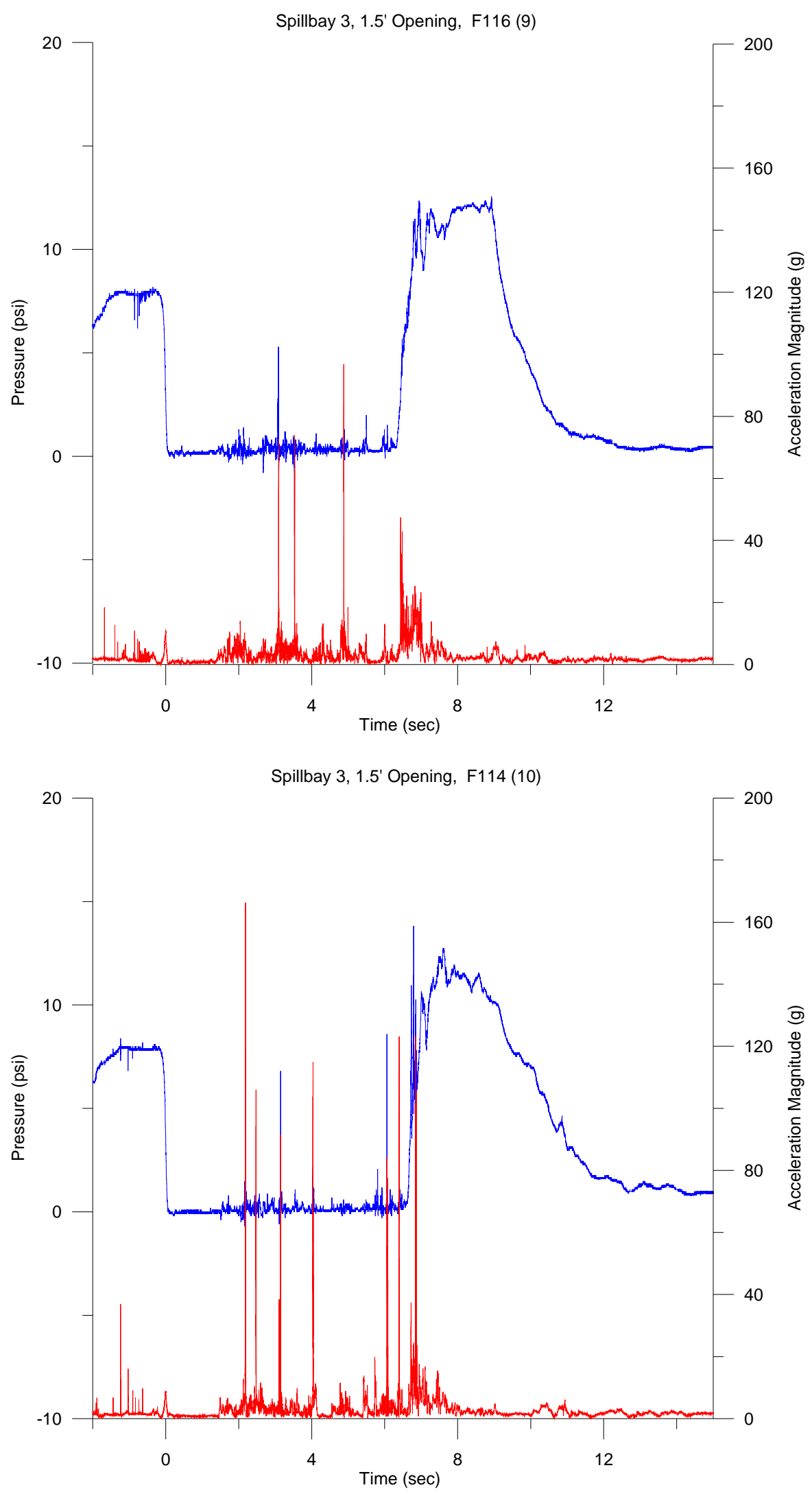

C. 6 

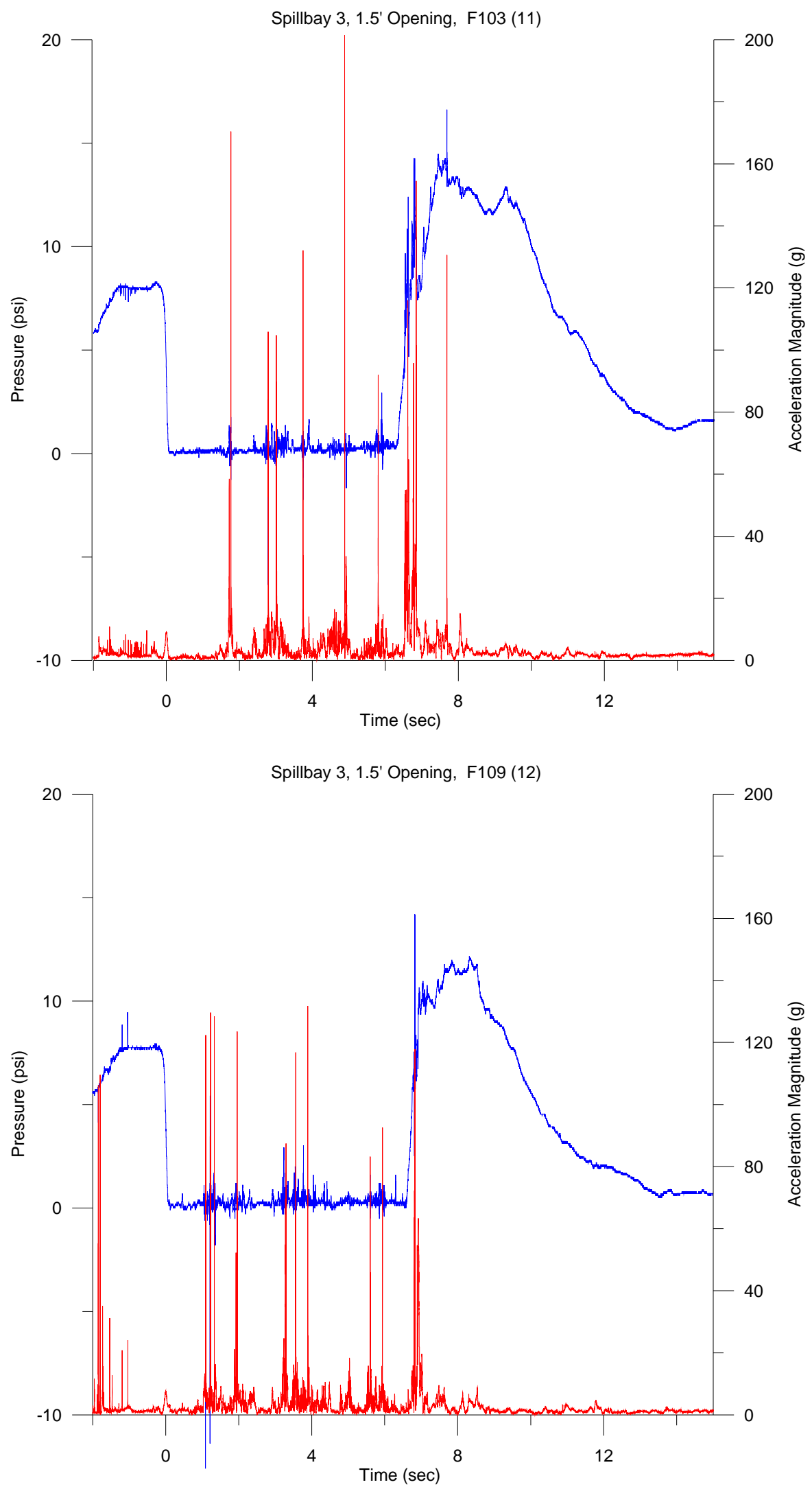

C.7 

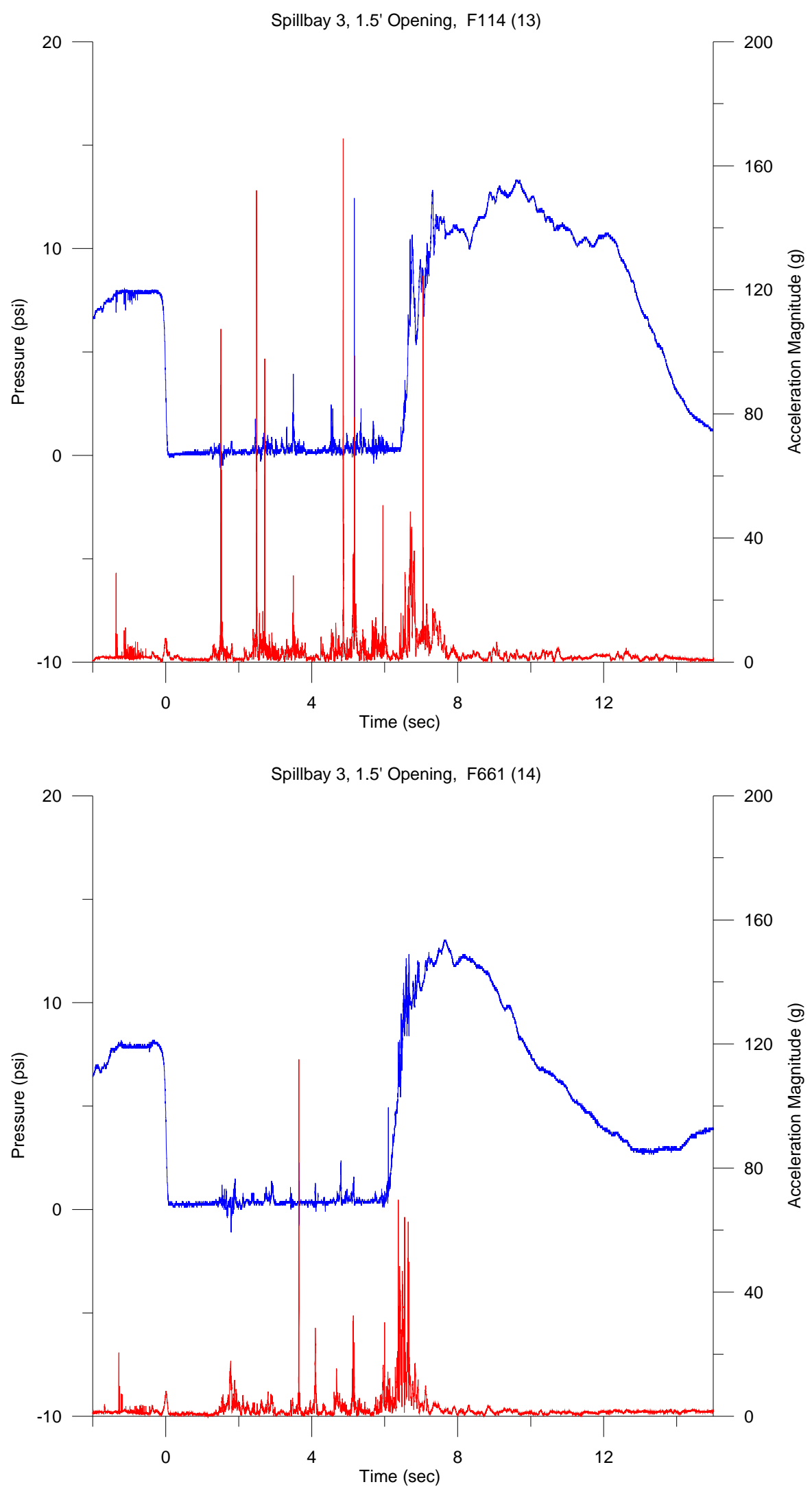

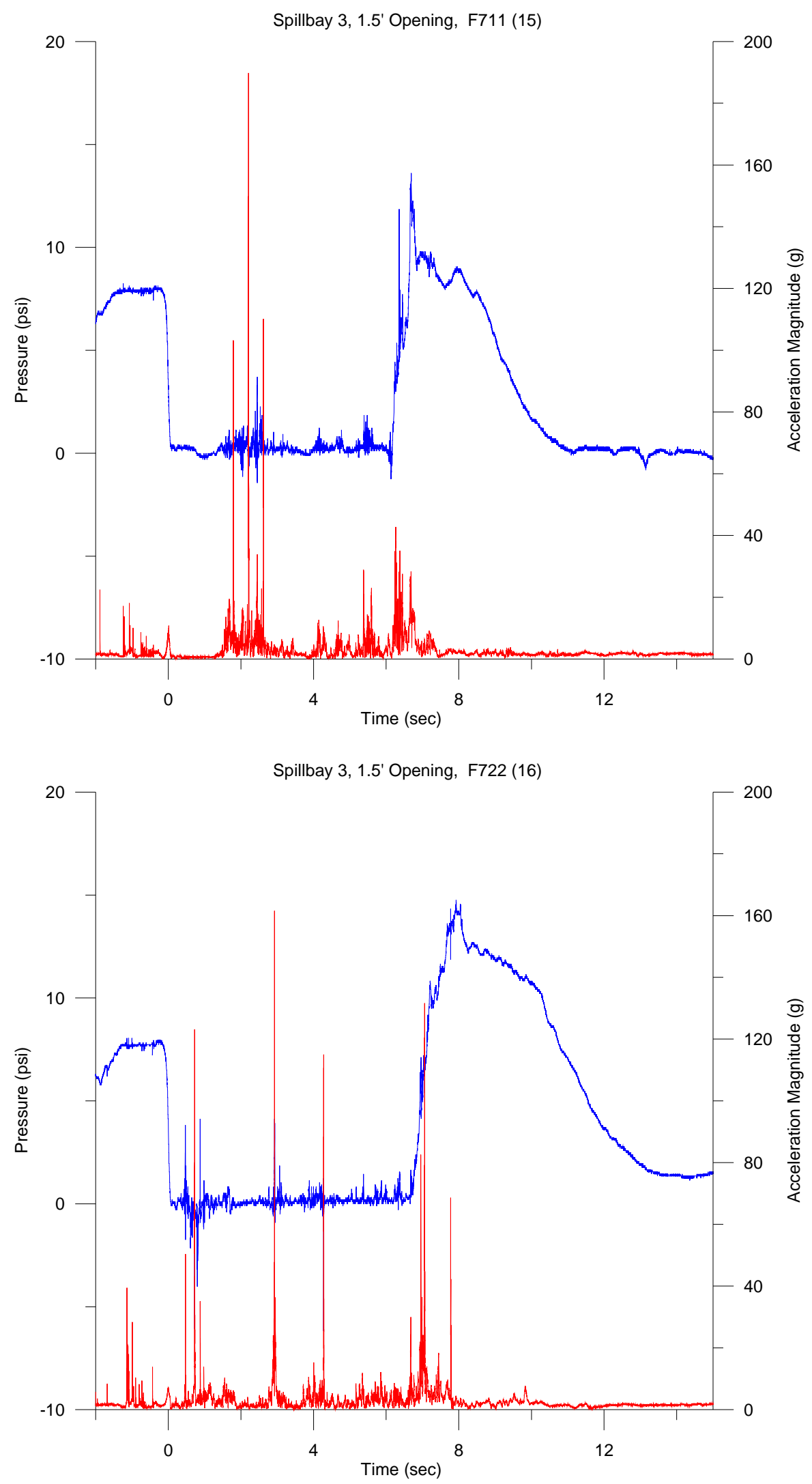

C.9 

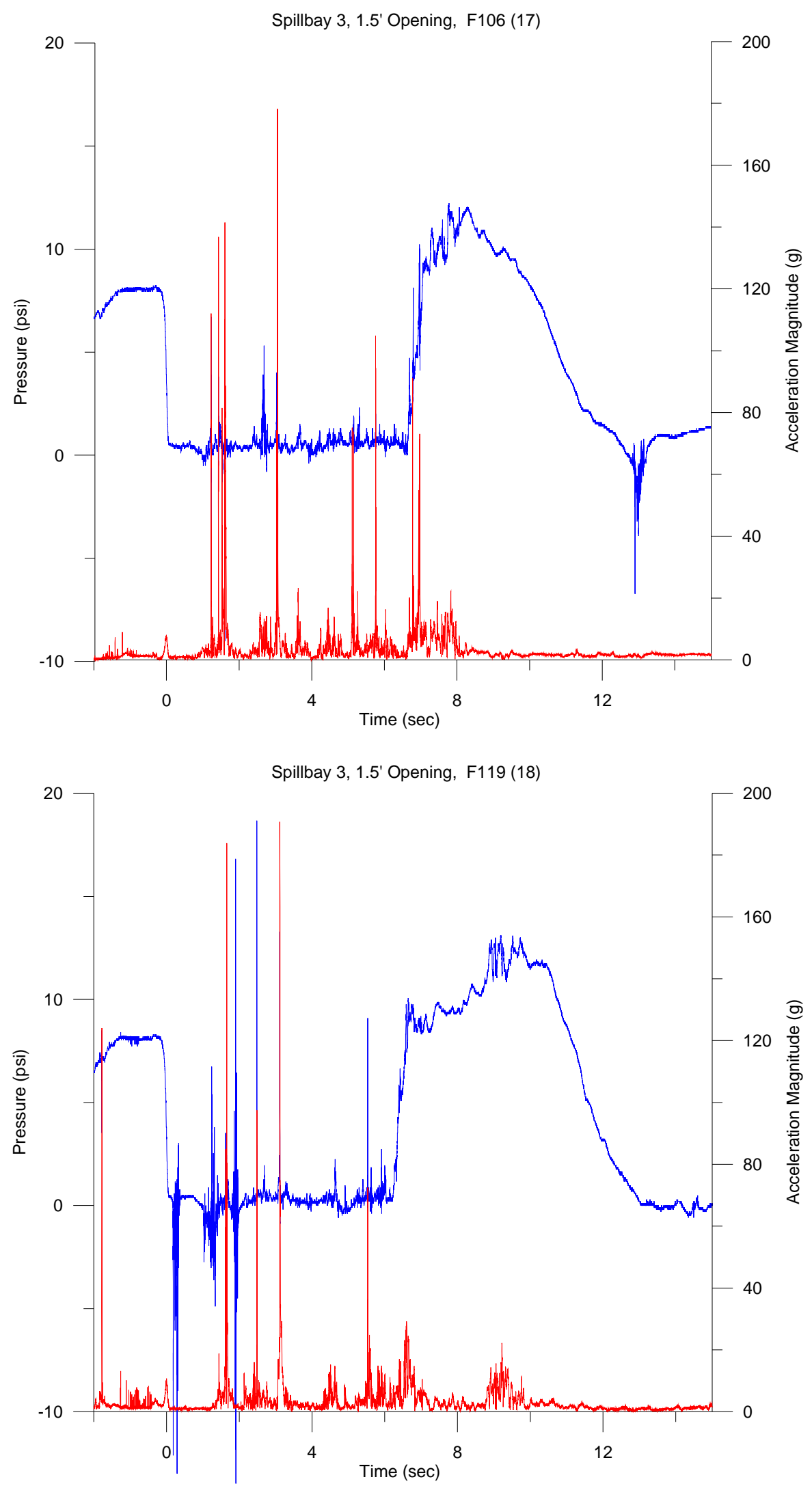

C.10 

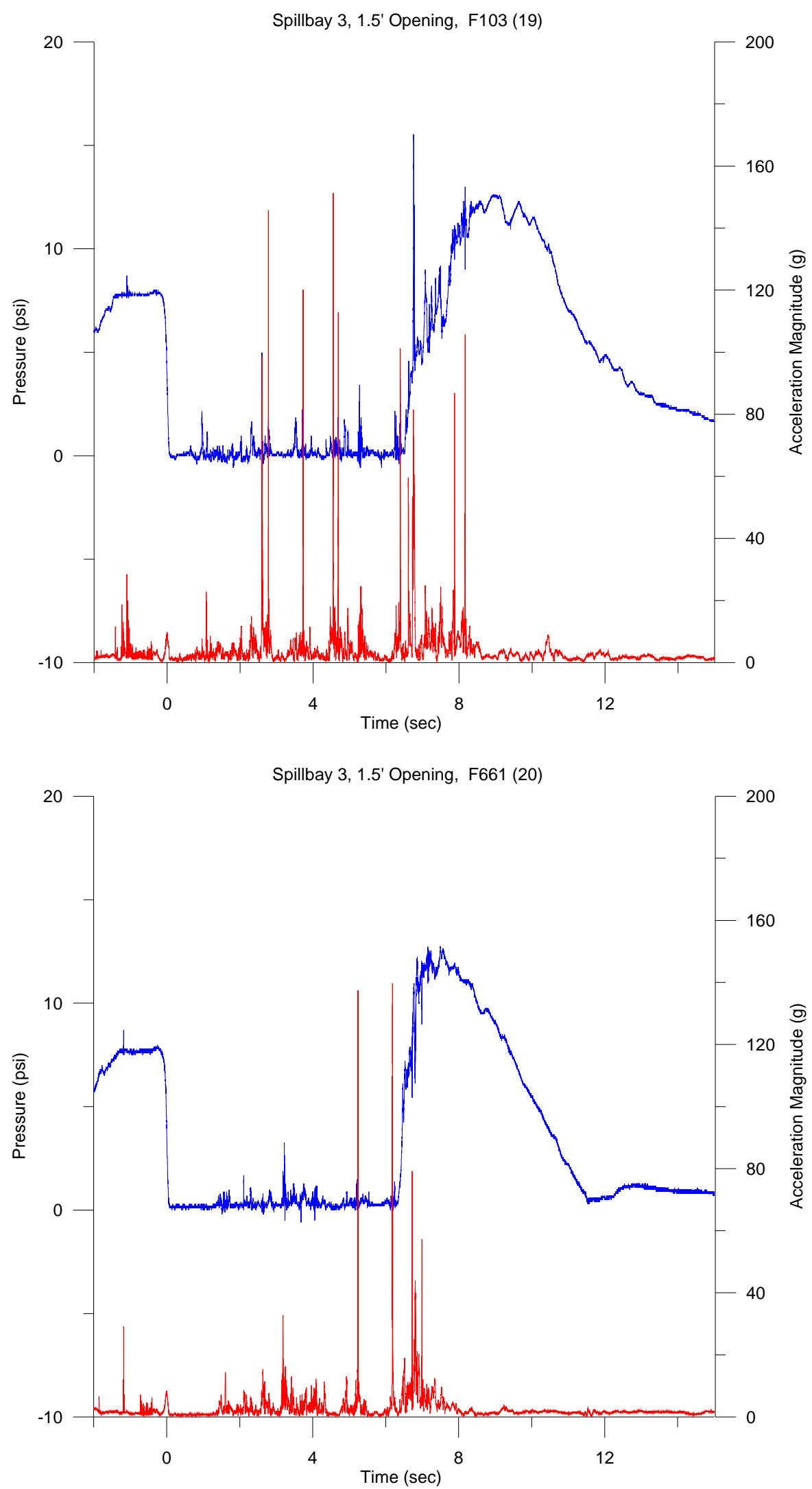

C.11 

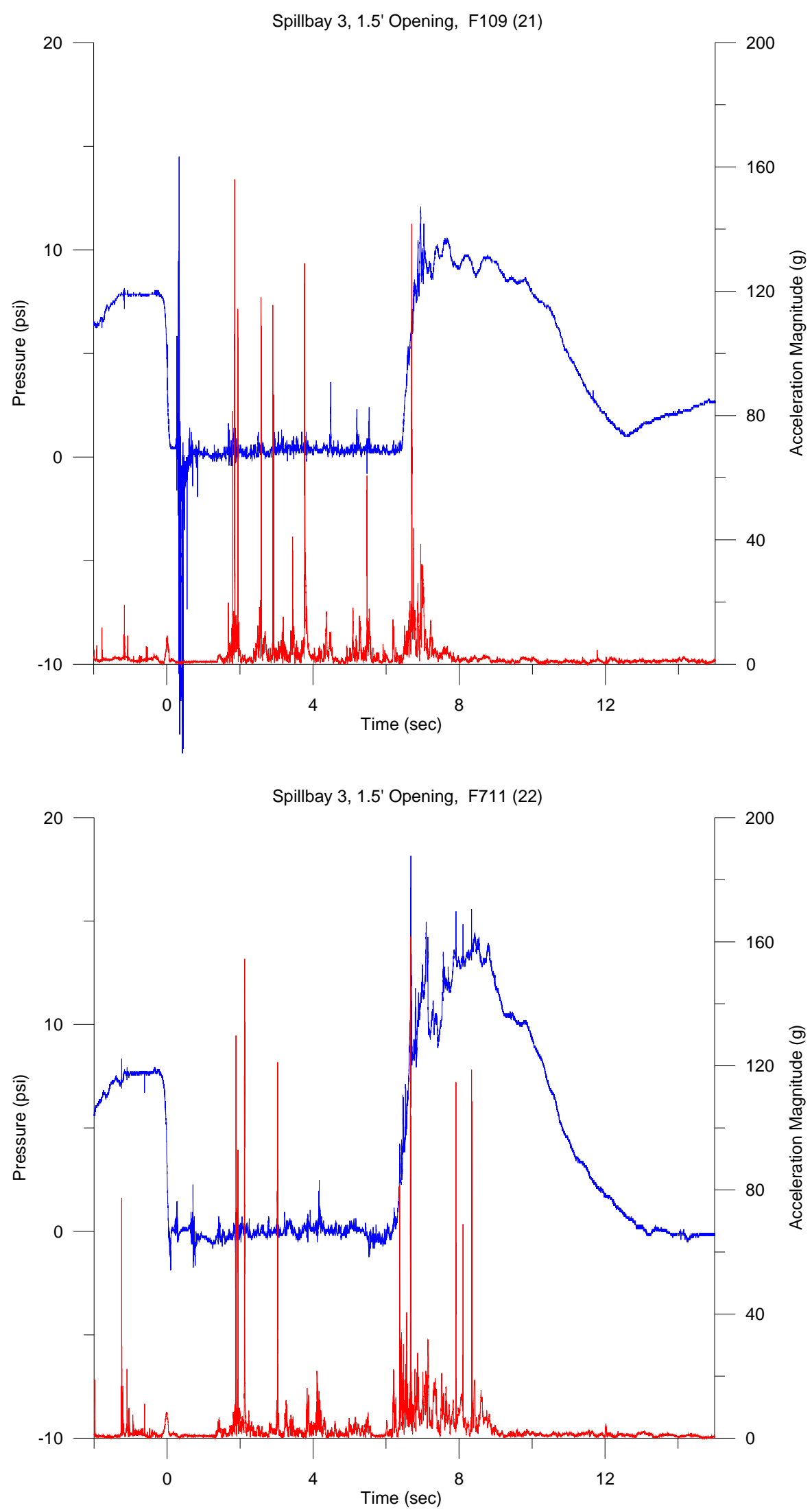

C.12 


\section{Spillbay 3, 3.5-ft Tainter Gate Opening}



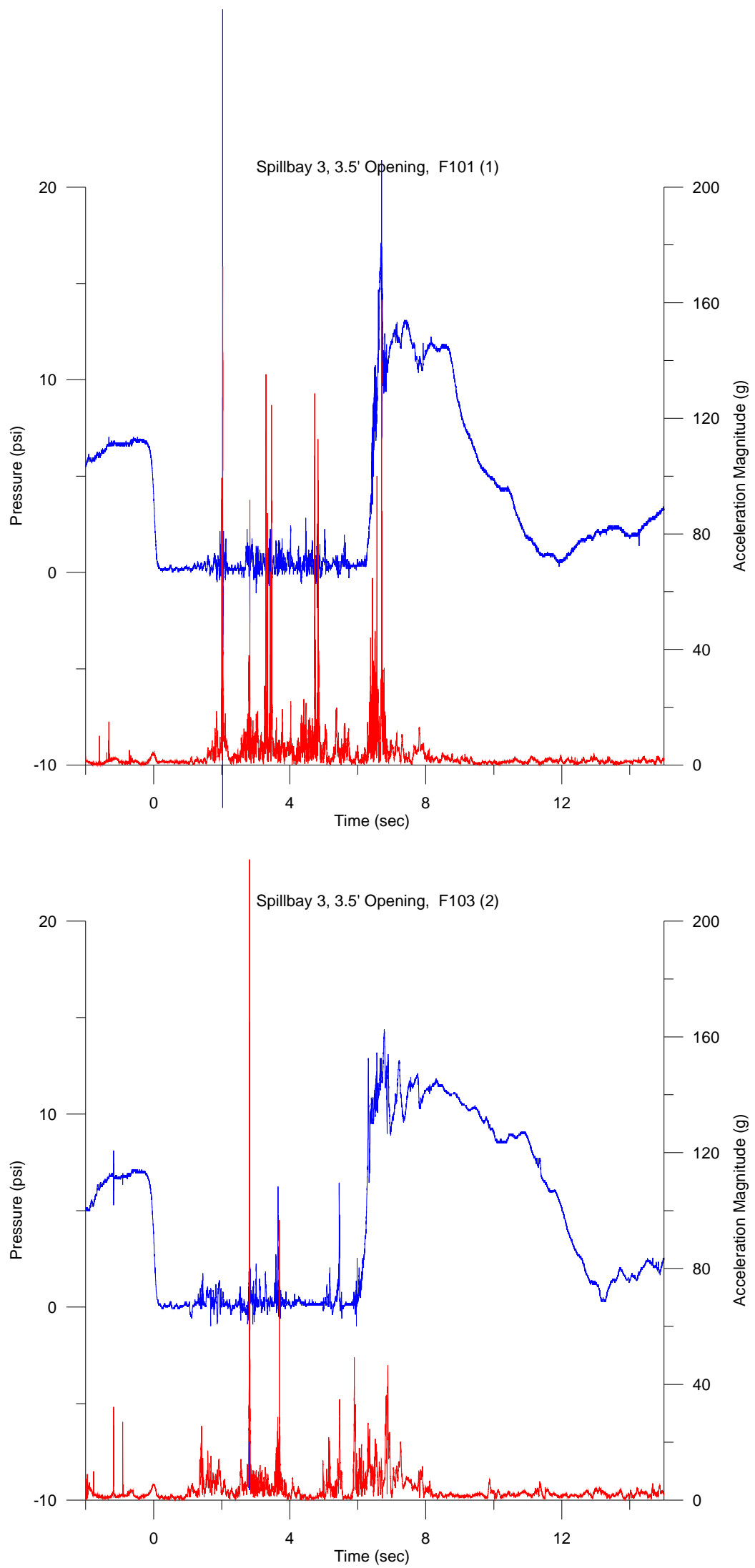

C.15 

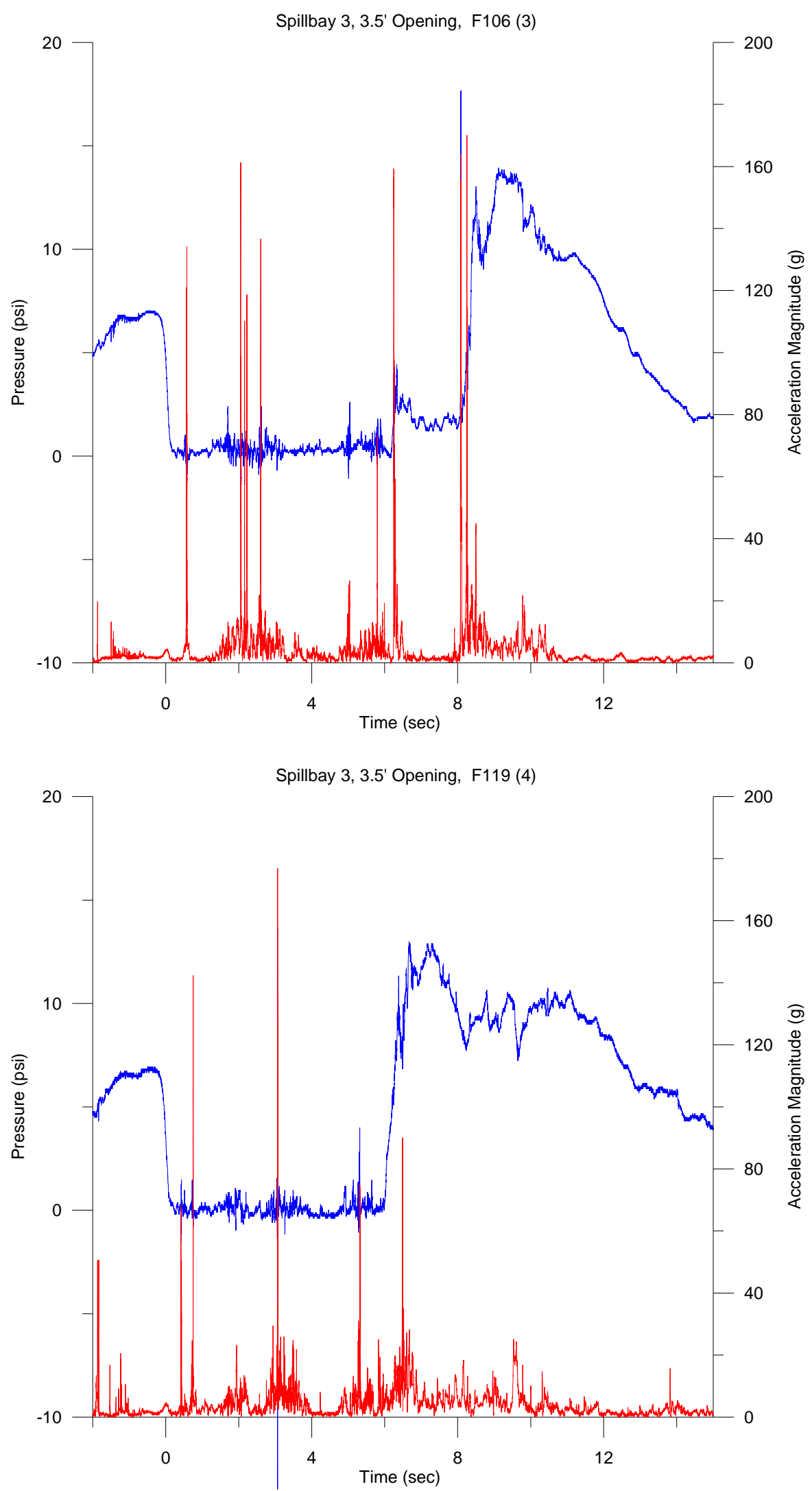

C.16 

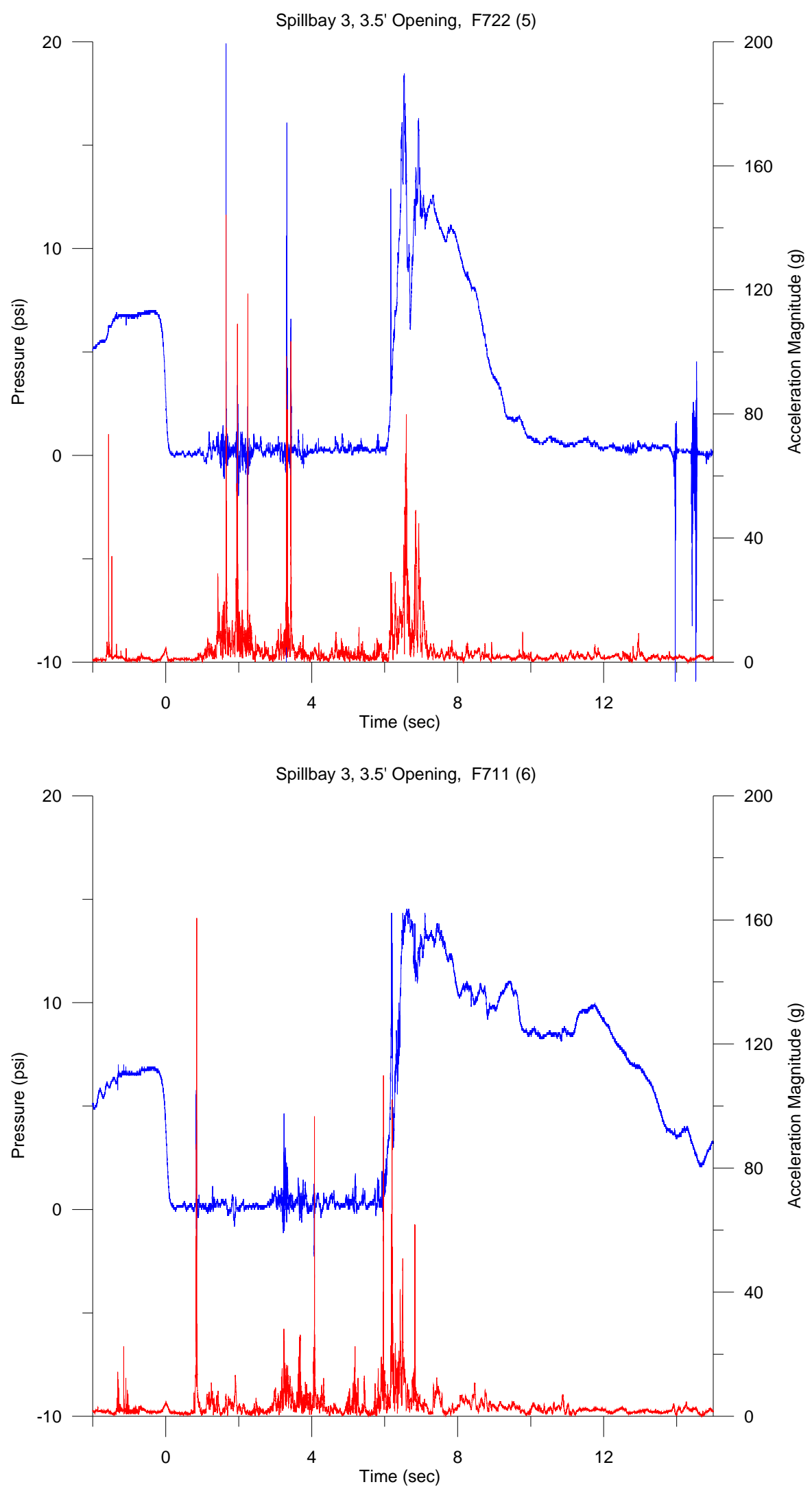

C.17 


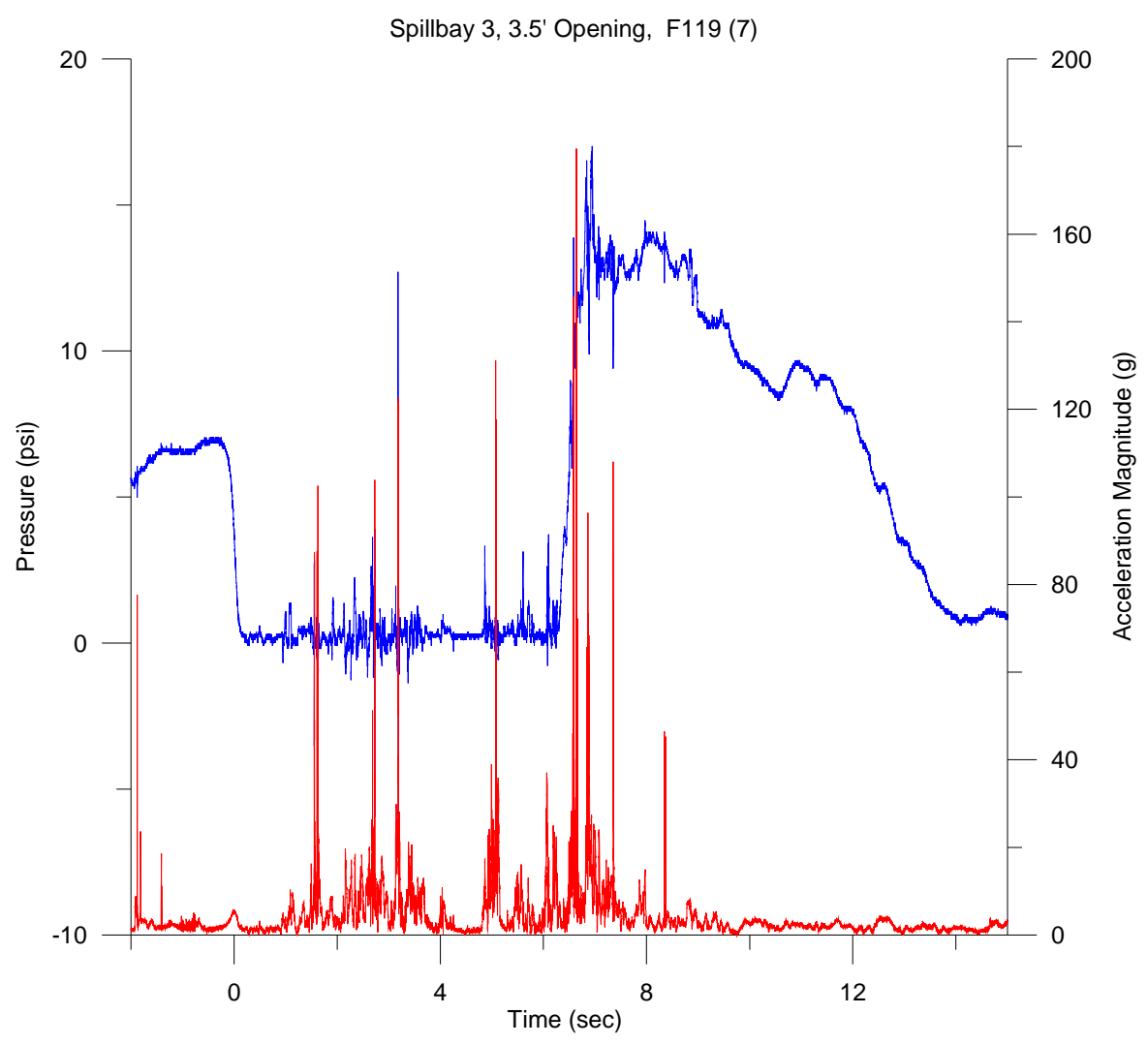




\section{Spillbay 6, 1.5-ft Tainter Gate Opening}



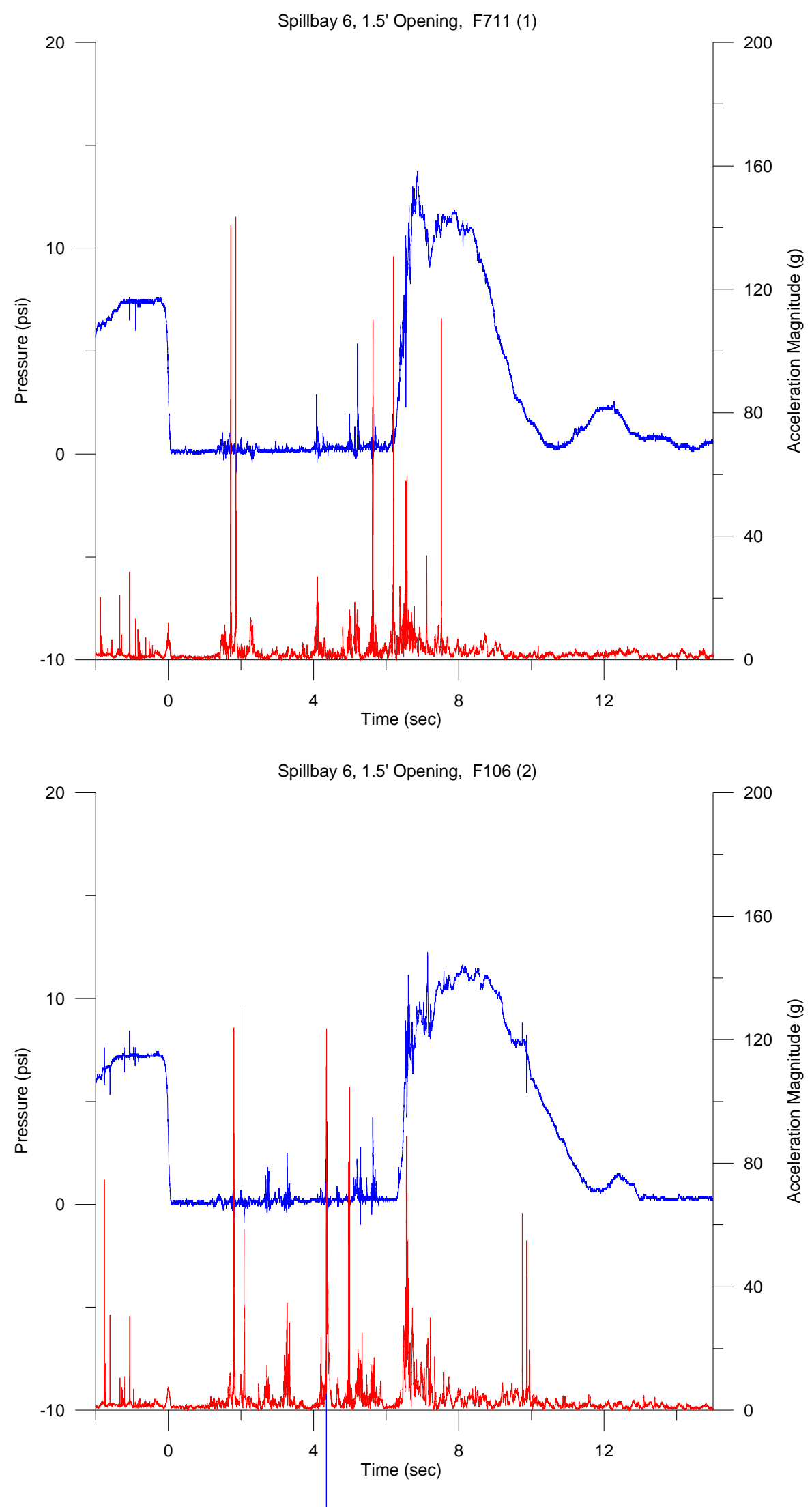

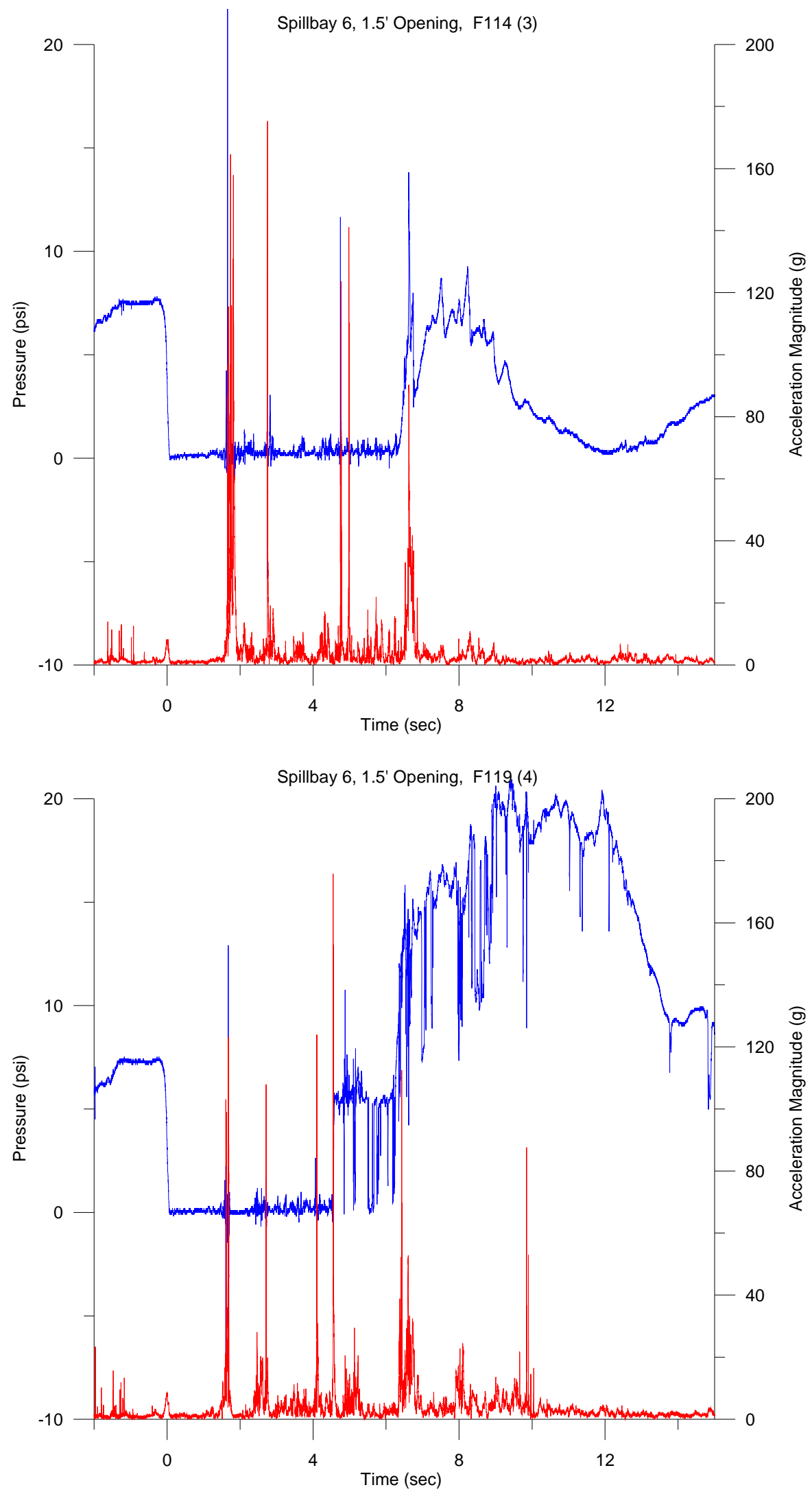

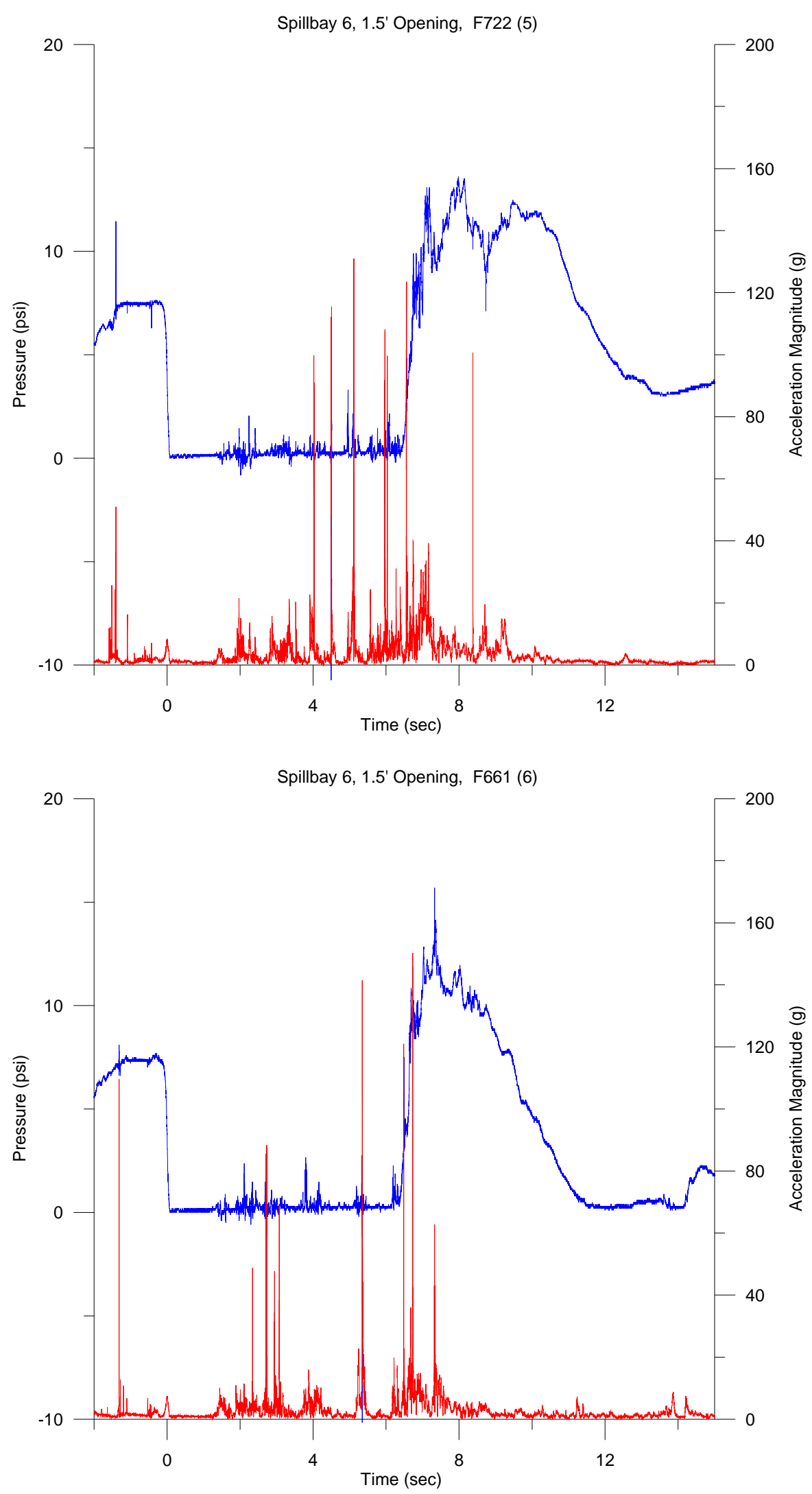

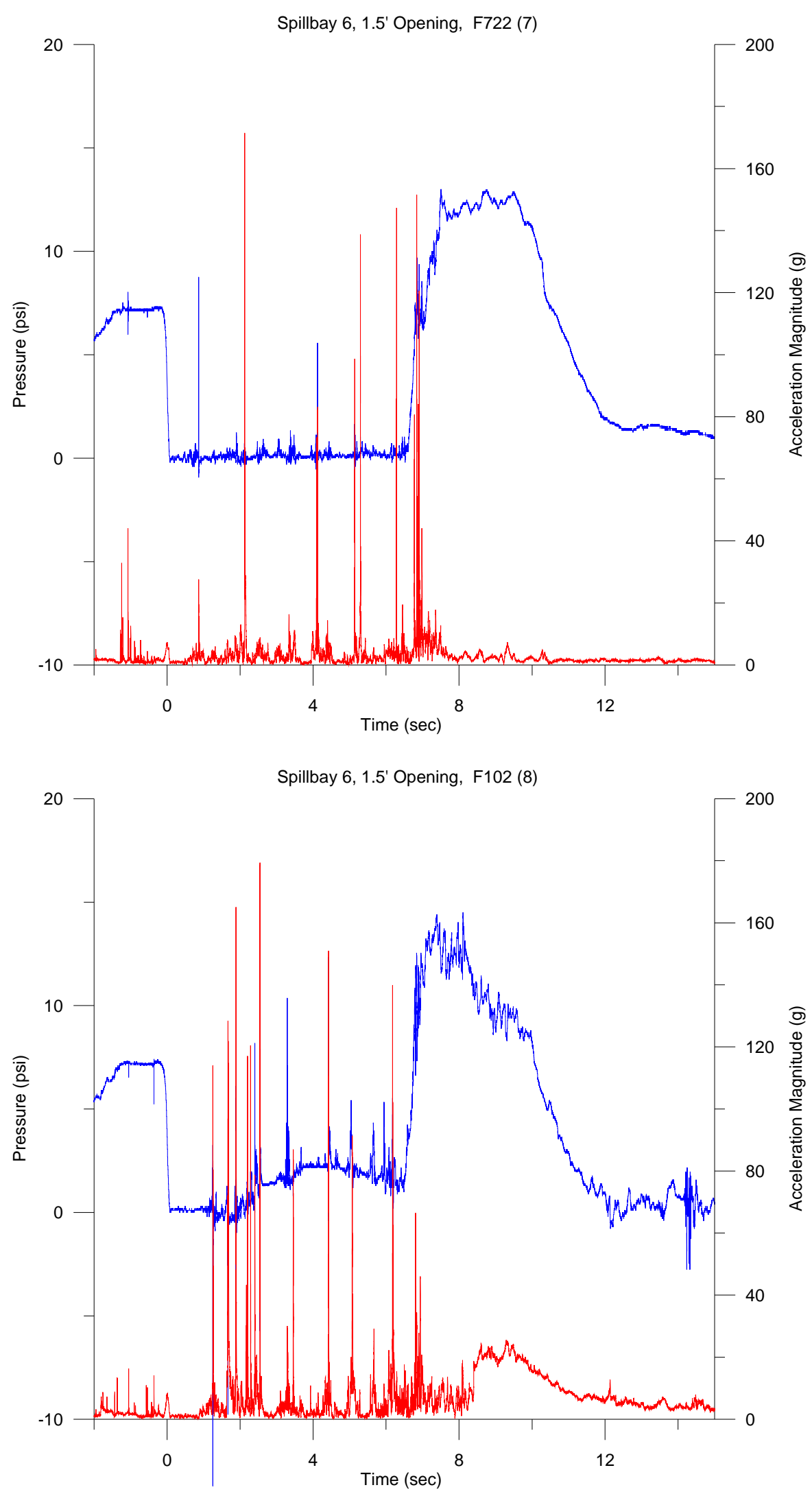

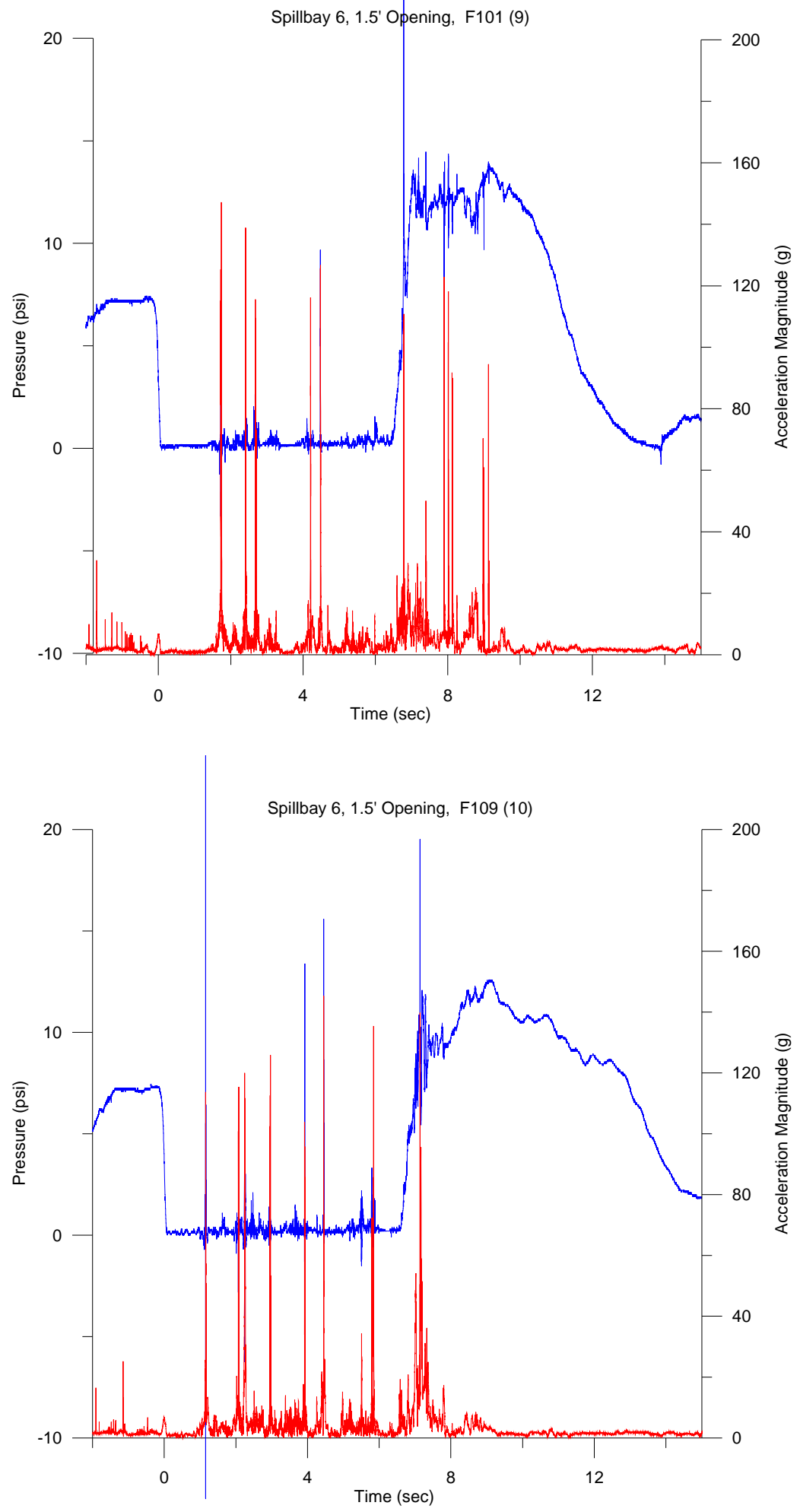

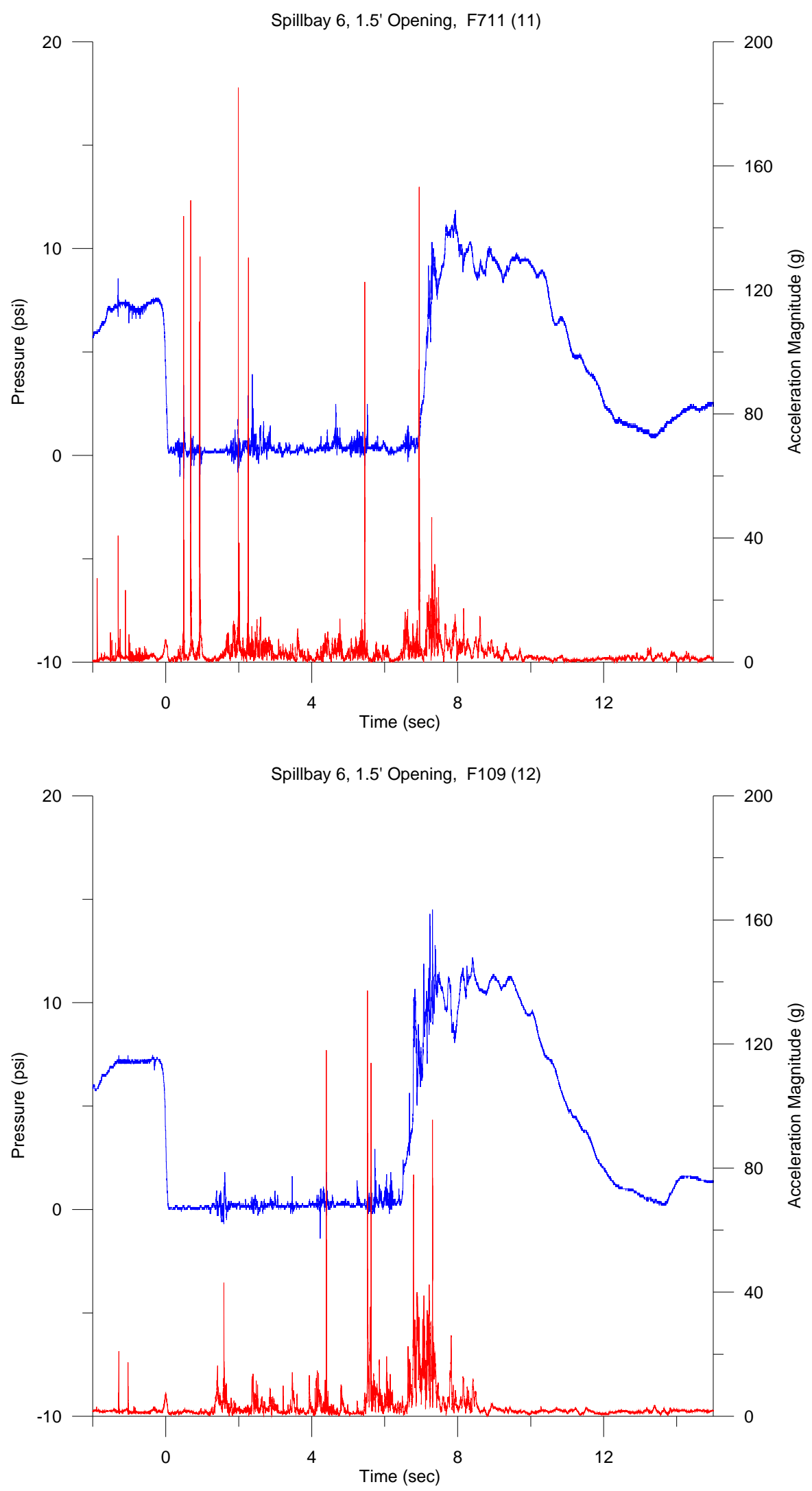

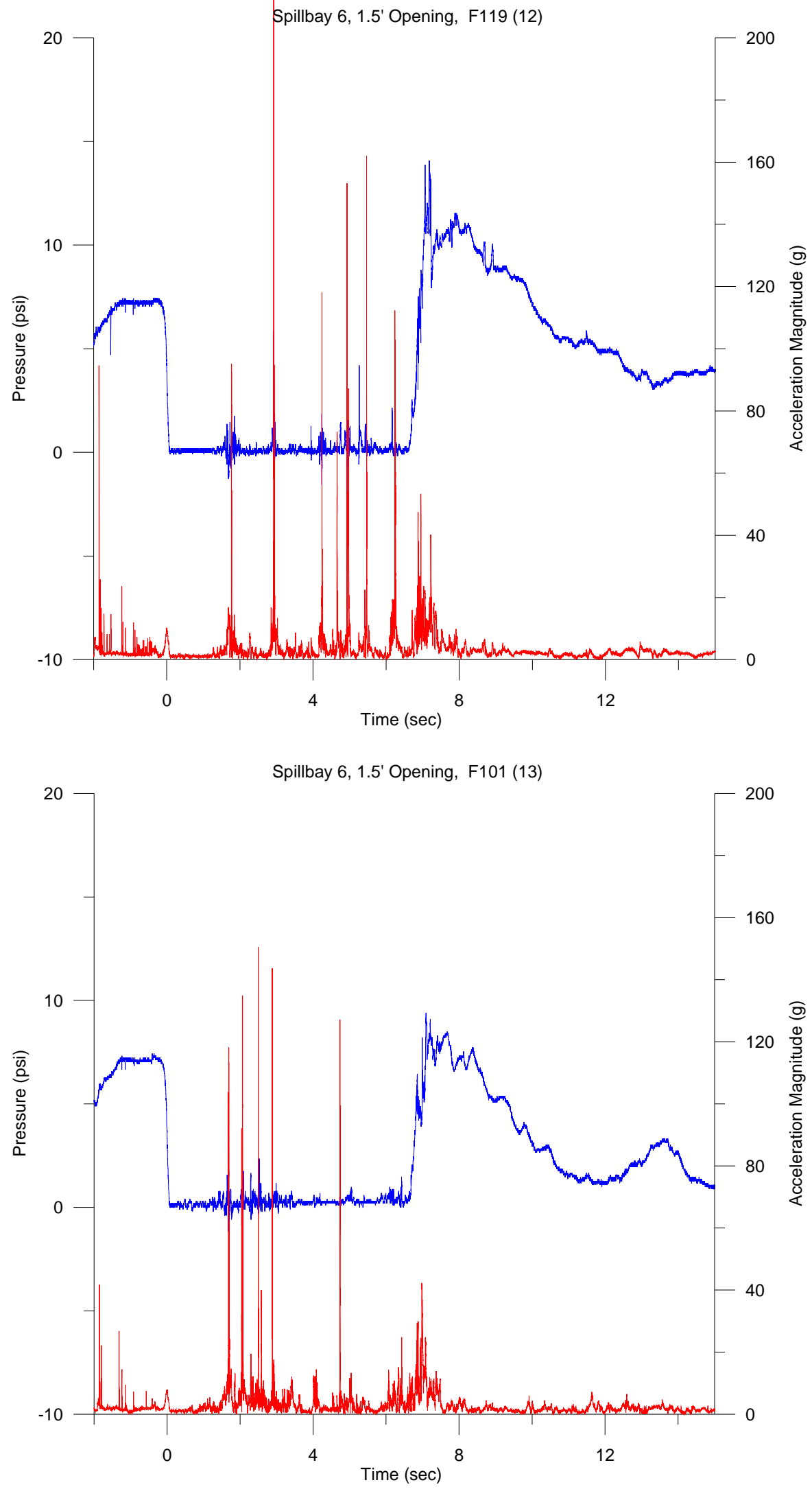

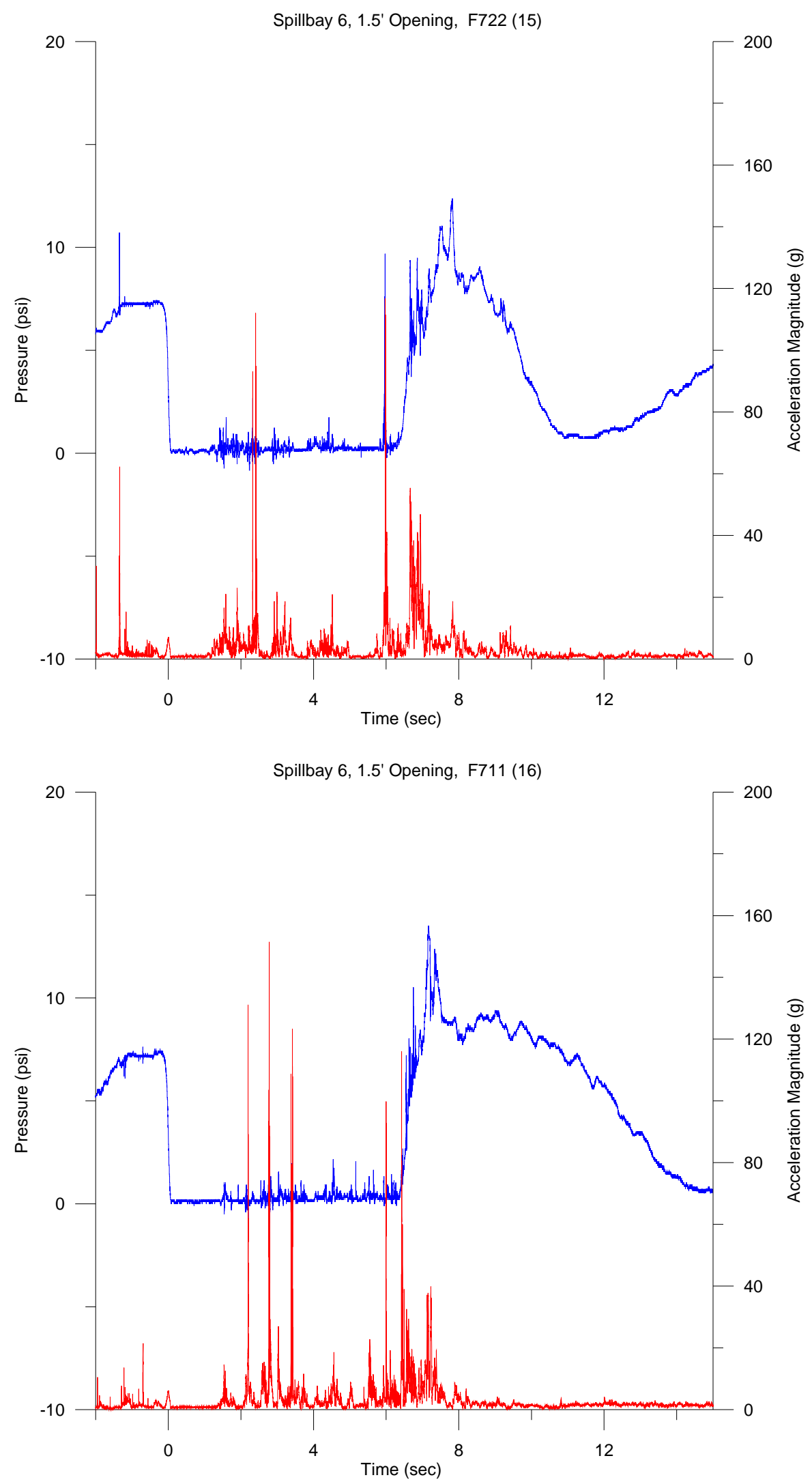


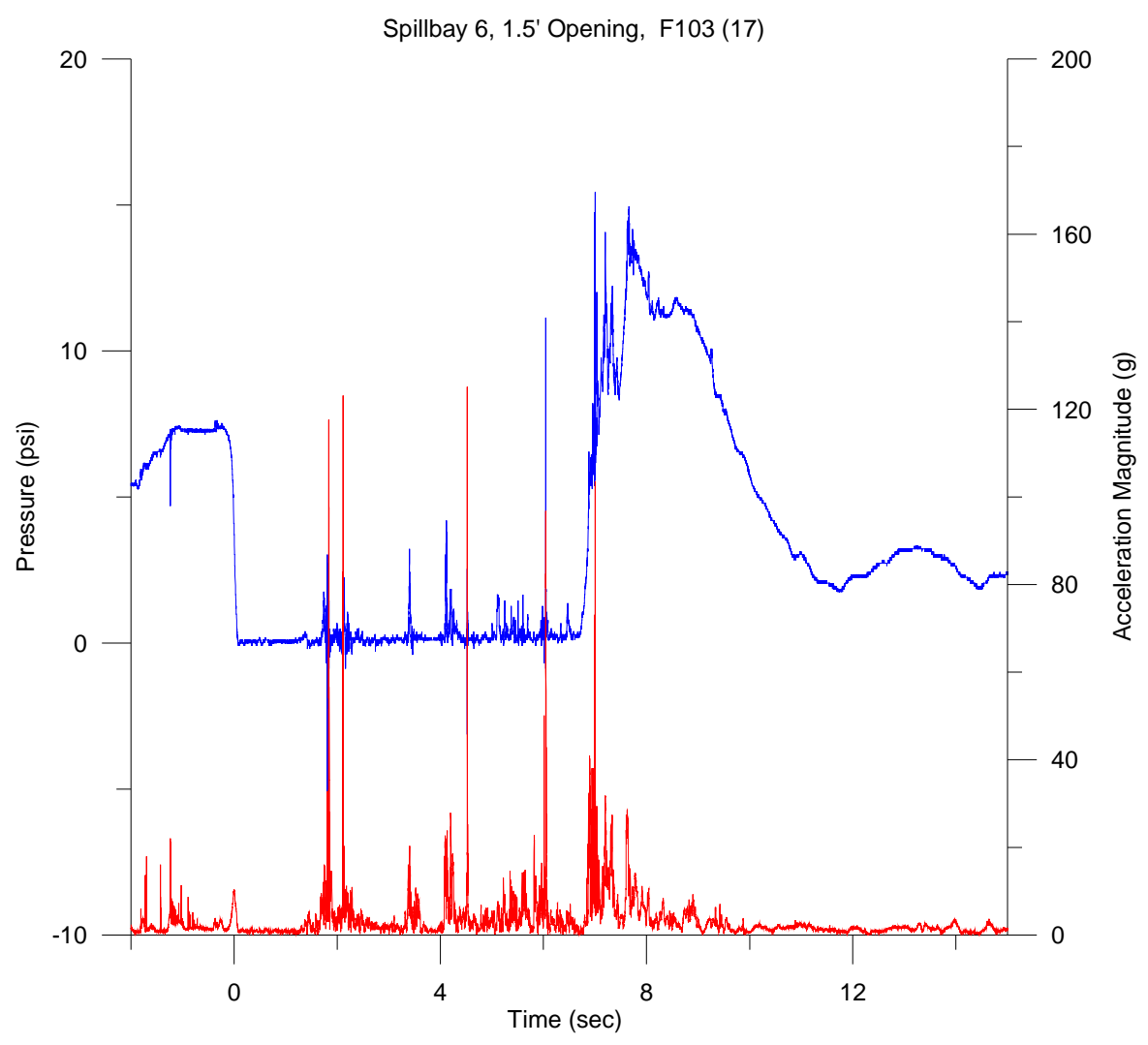




\section{Spillbay 6, 3.5 ft Tainter Gate Opening}



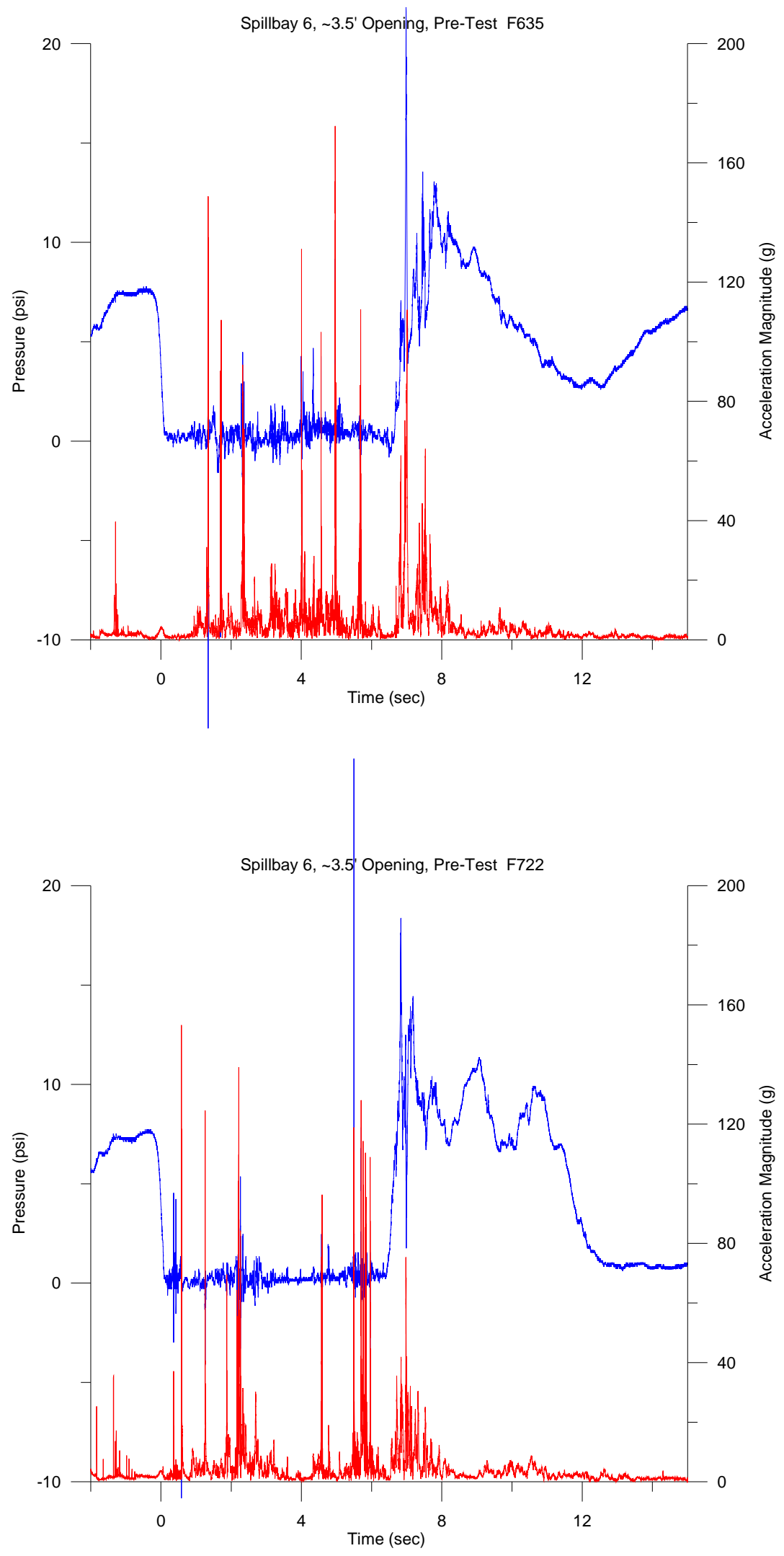

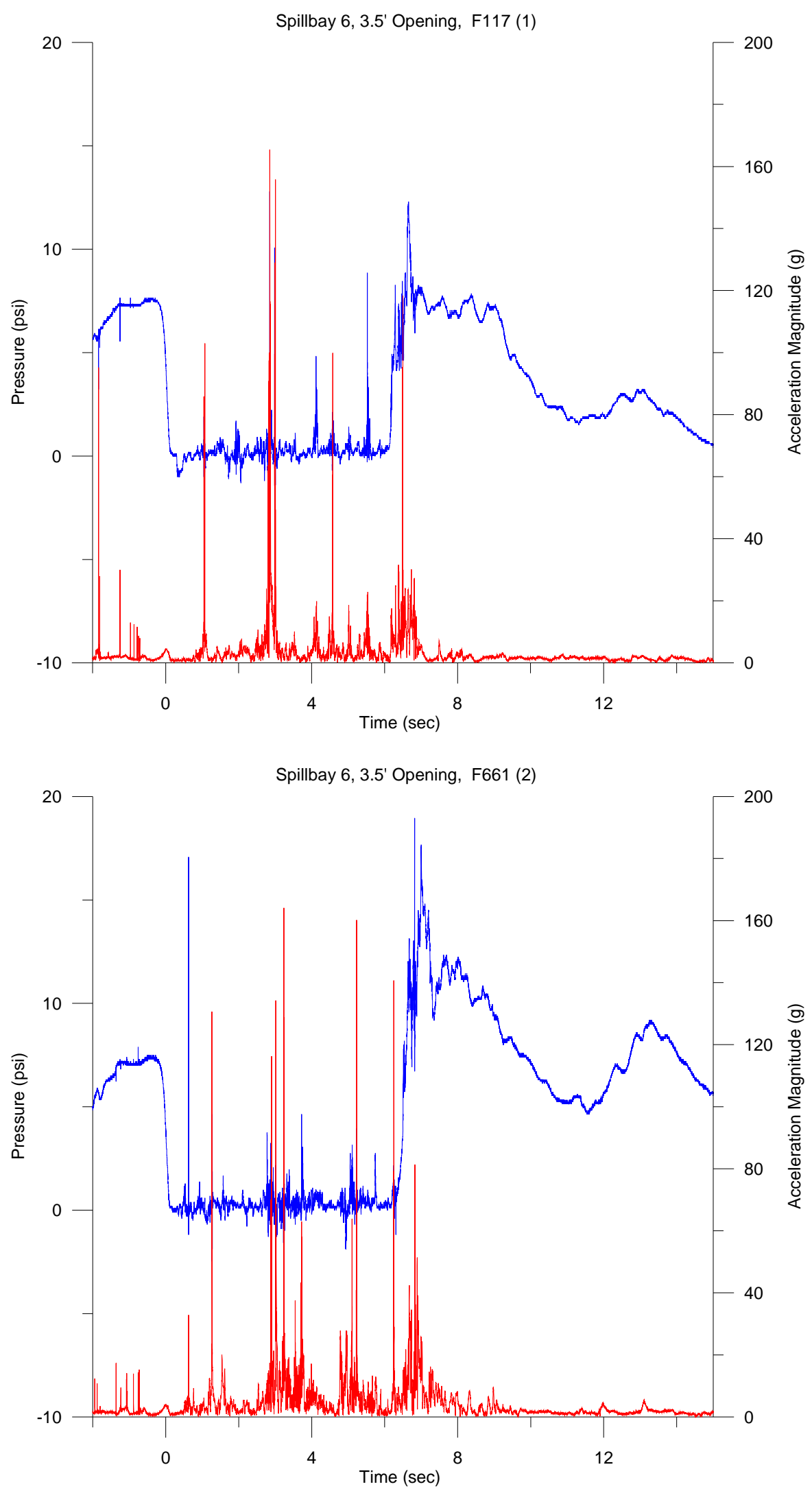


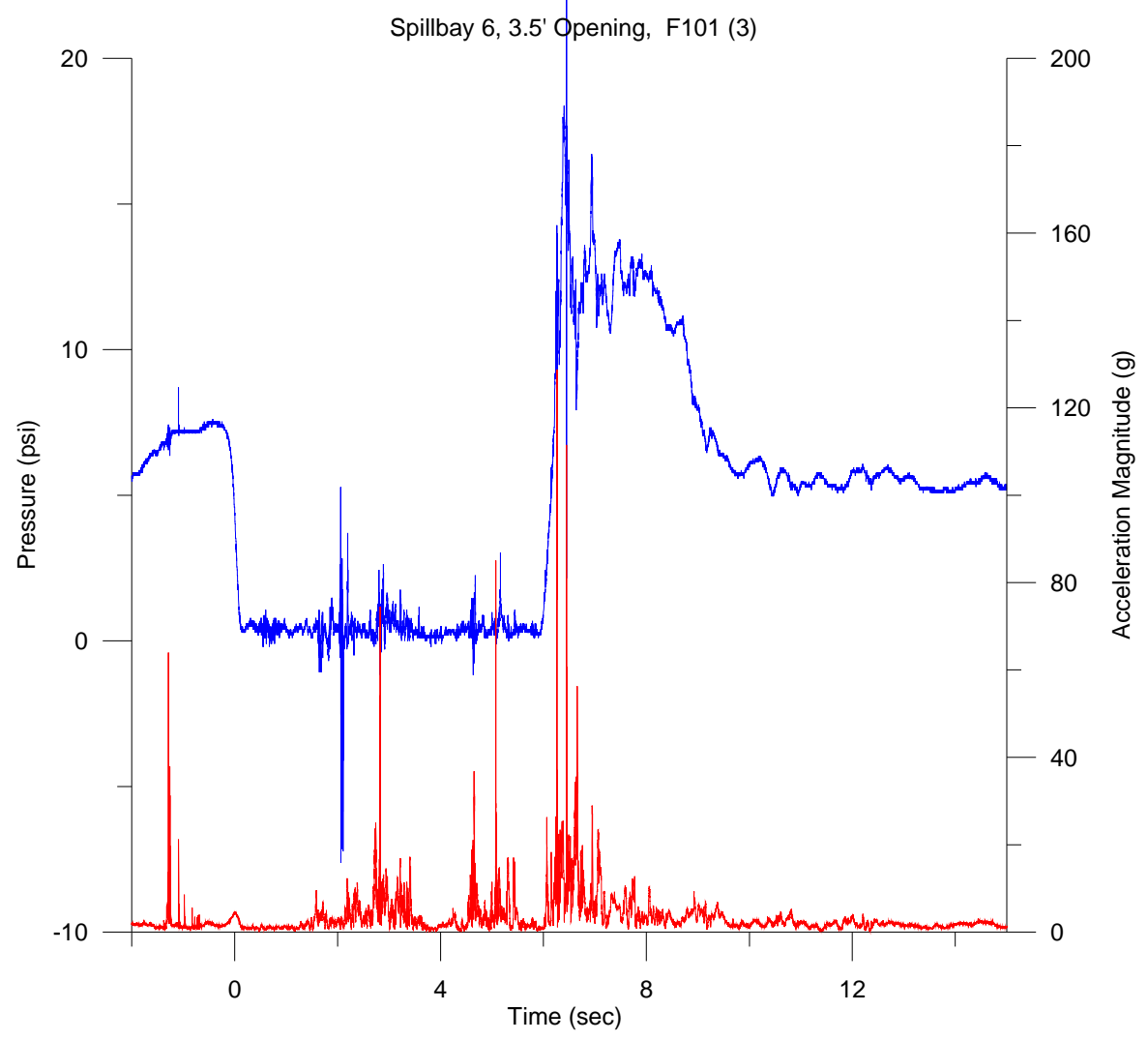



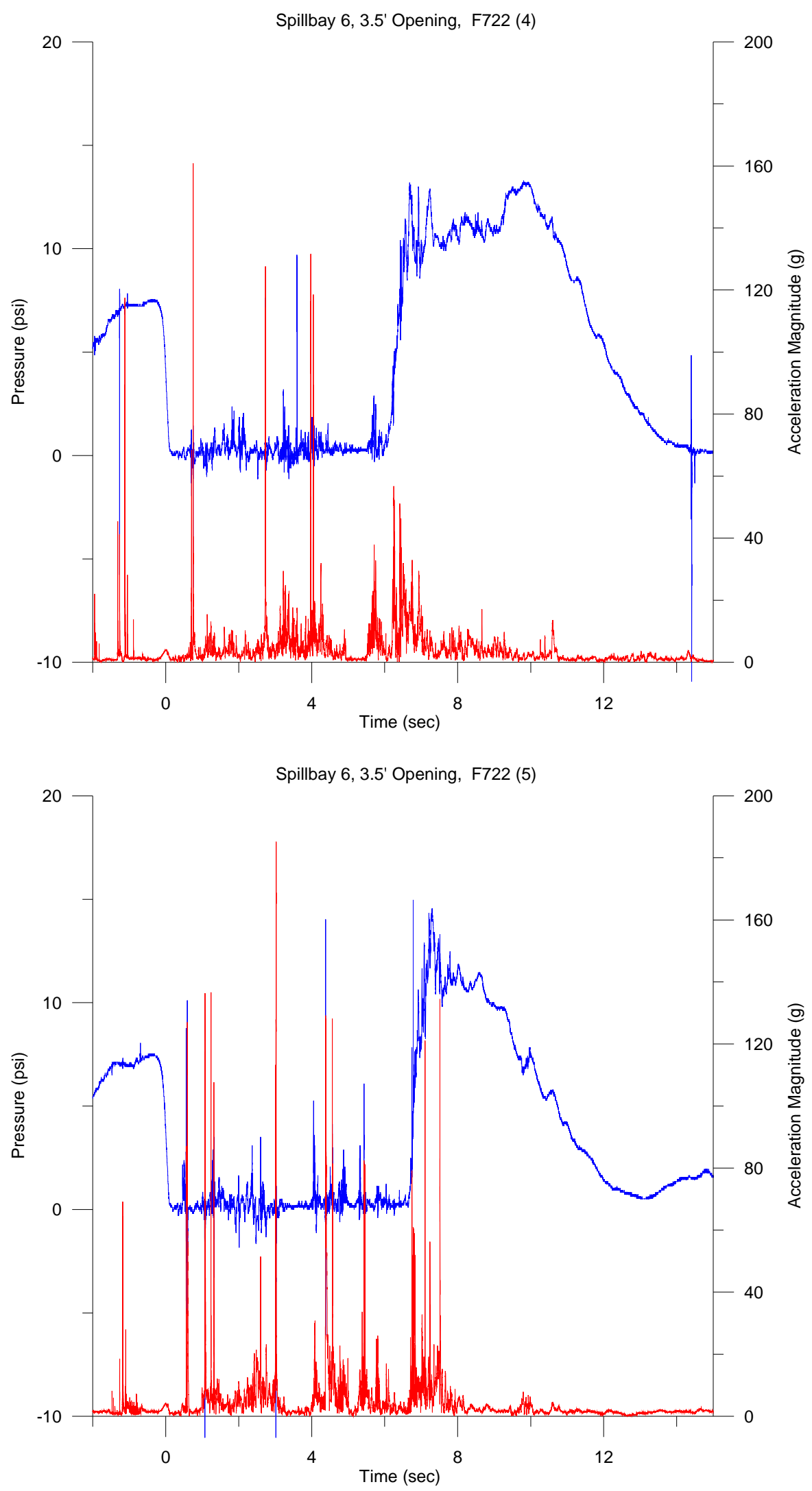

C.36 

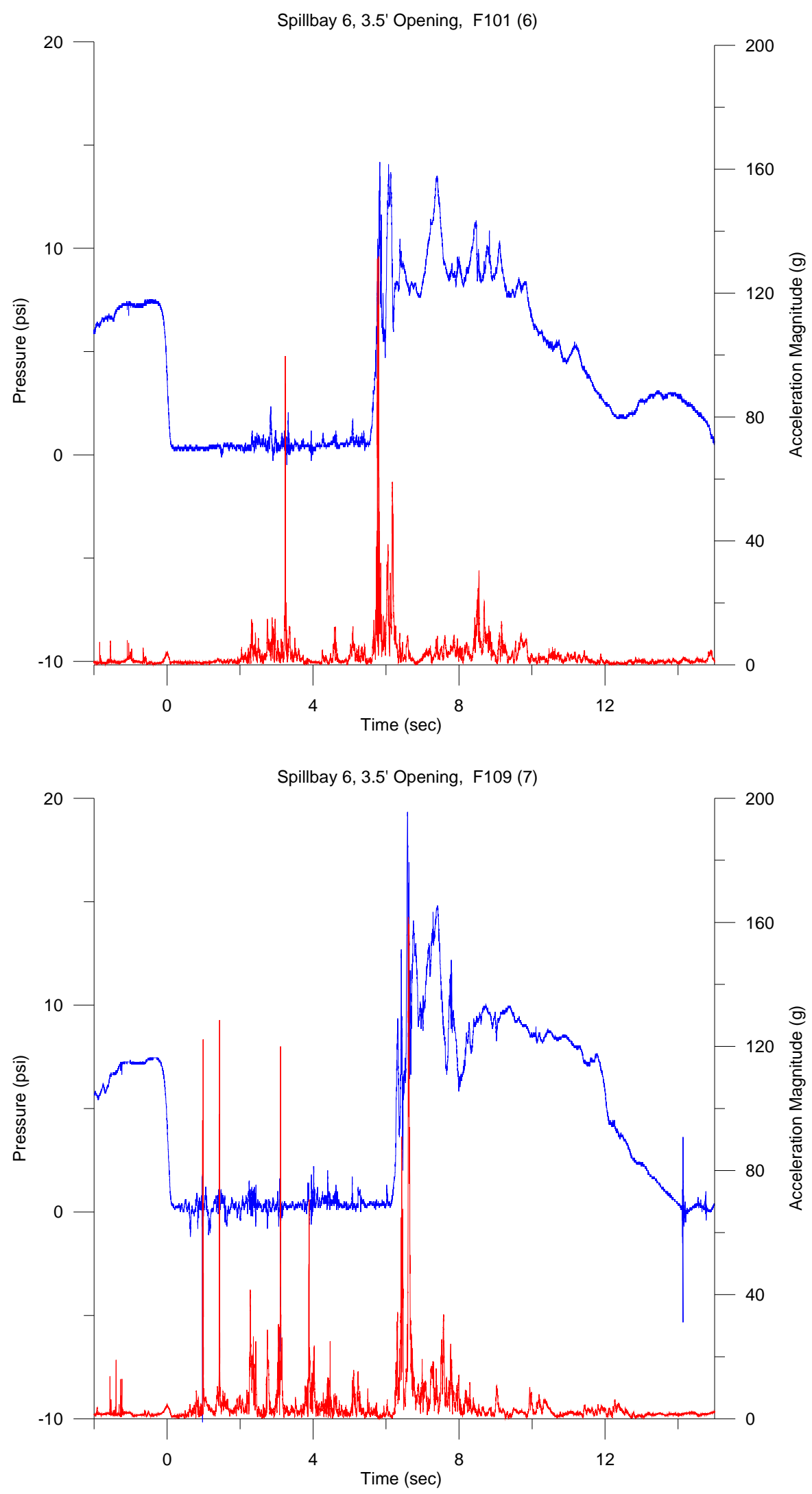

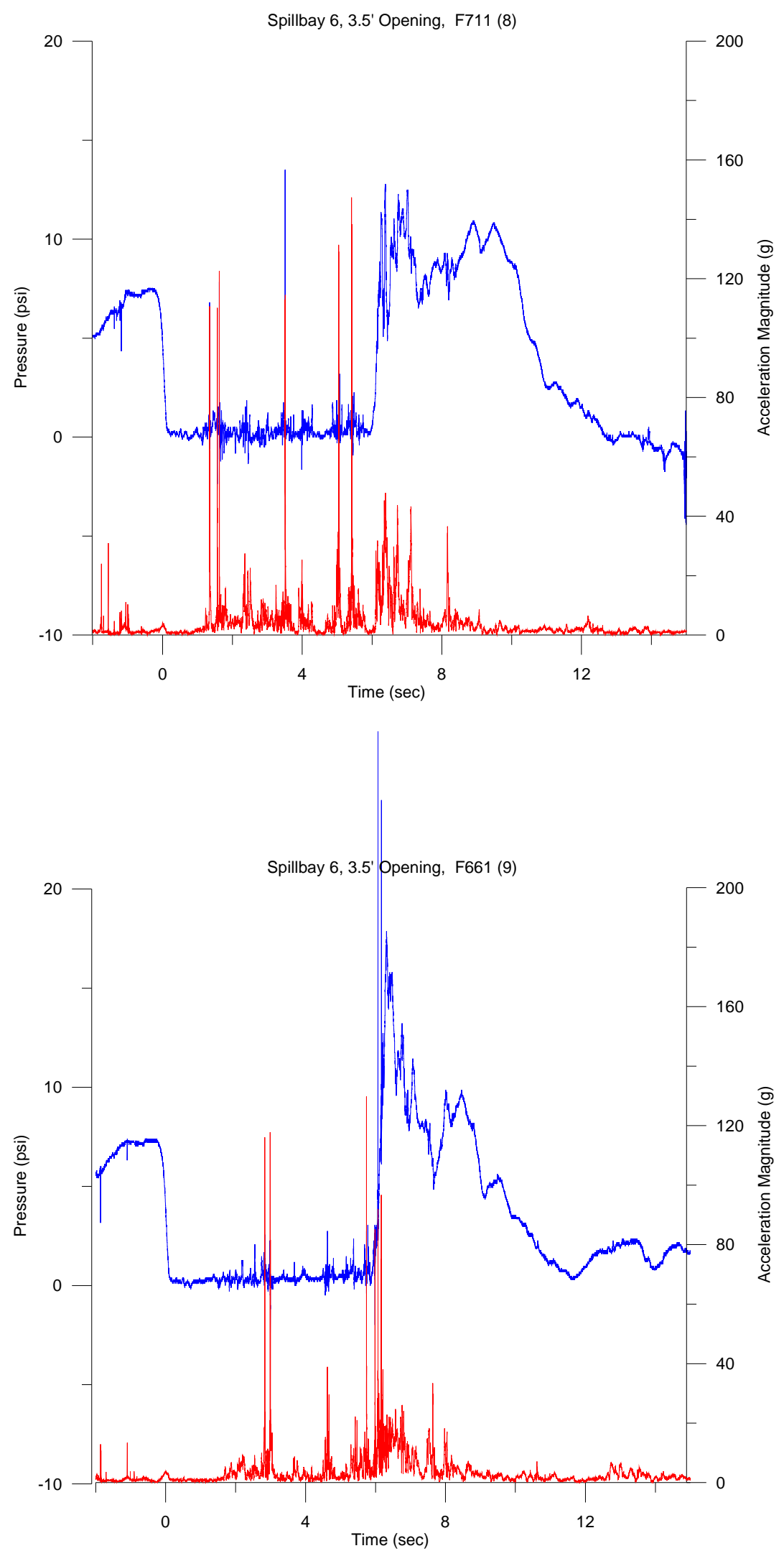


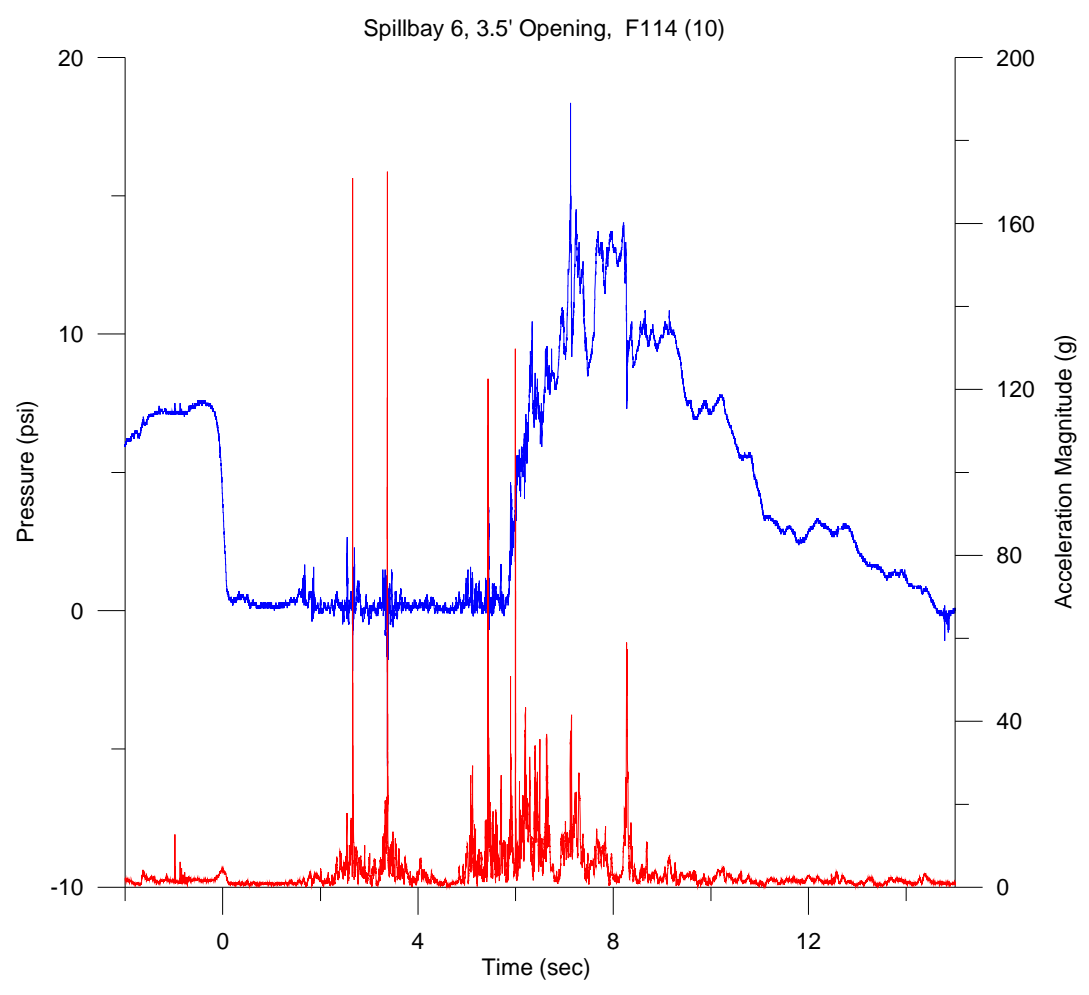



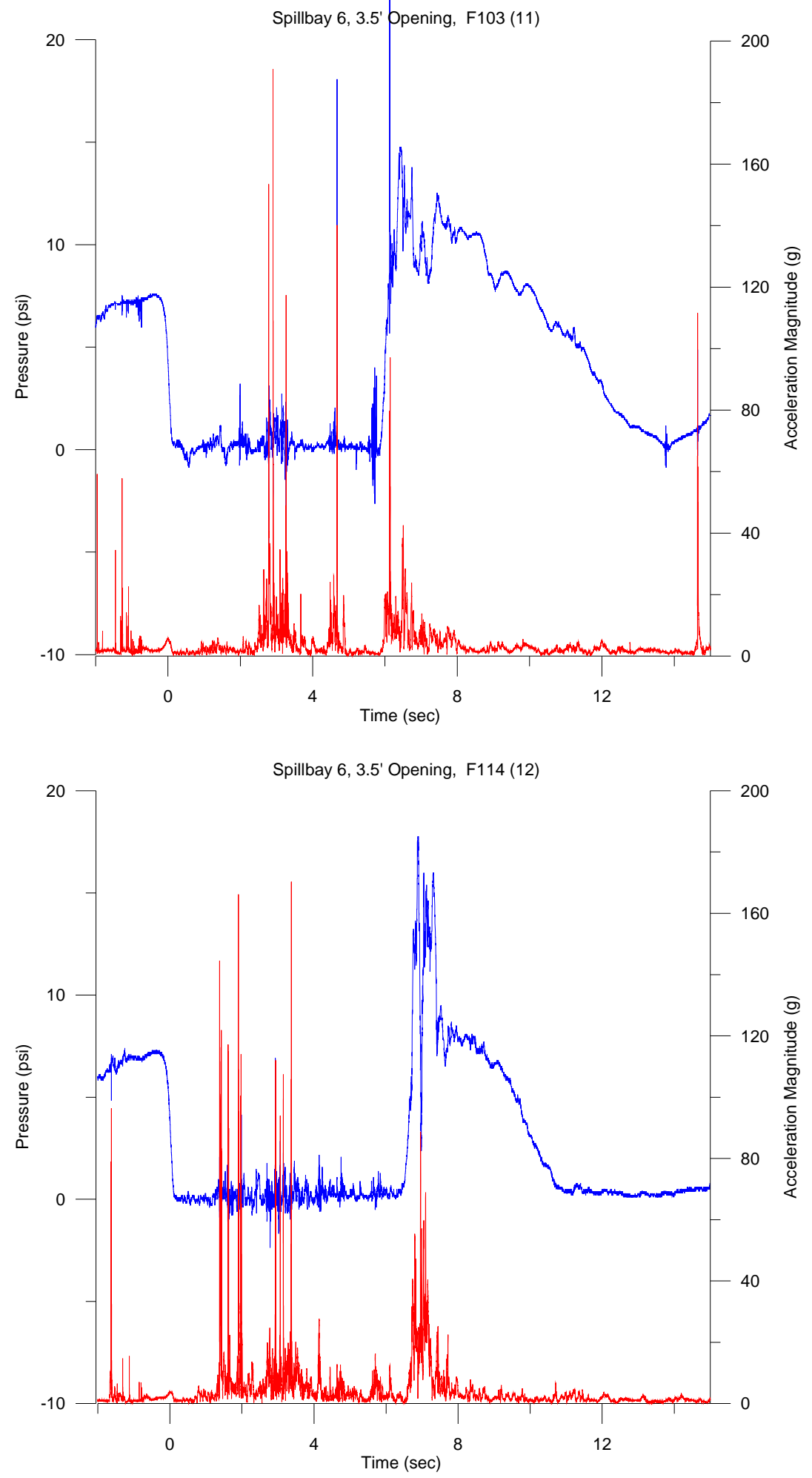

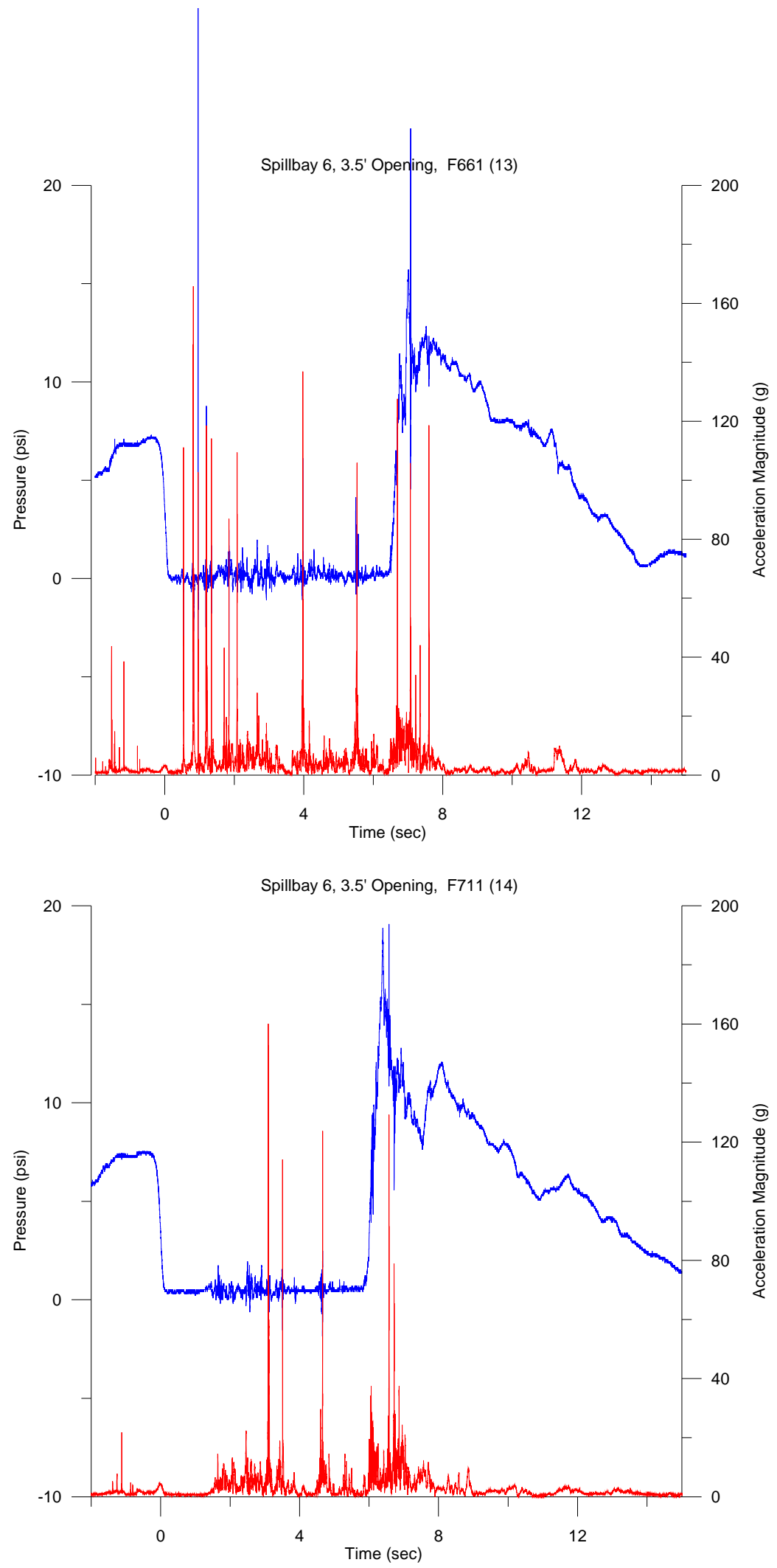

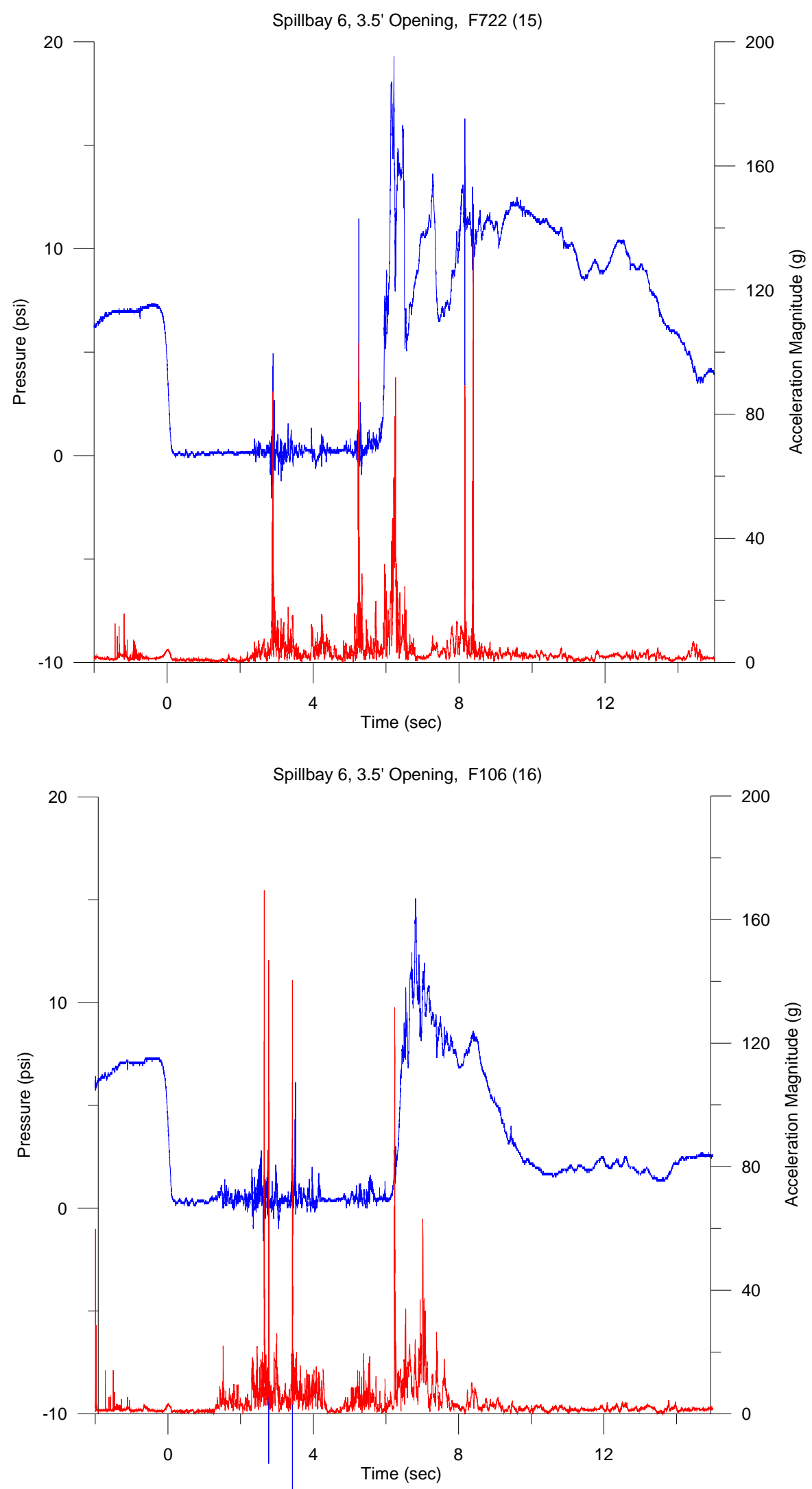

C. 42 

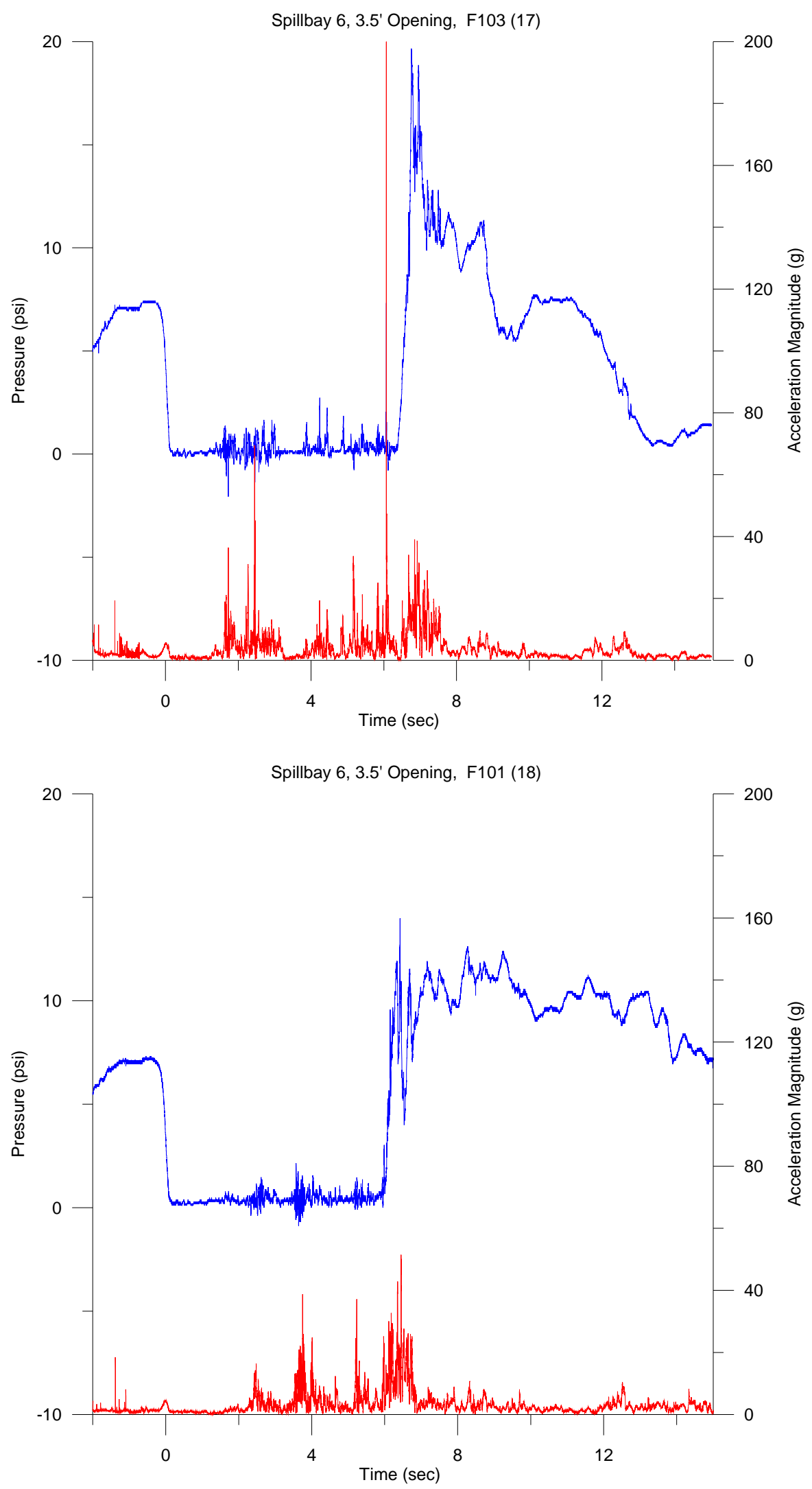

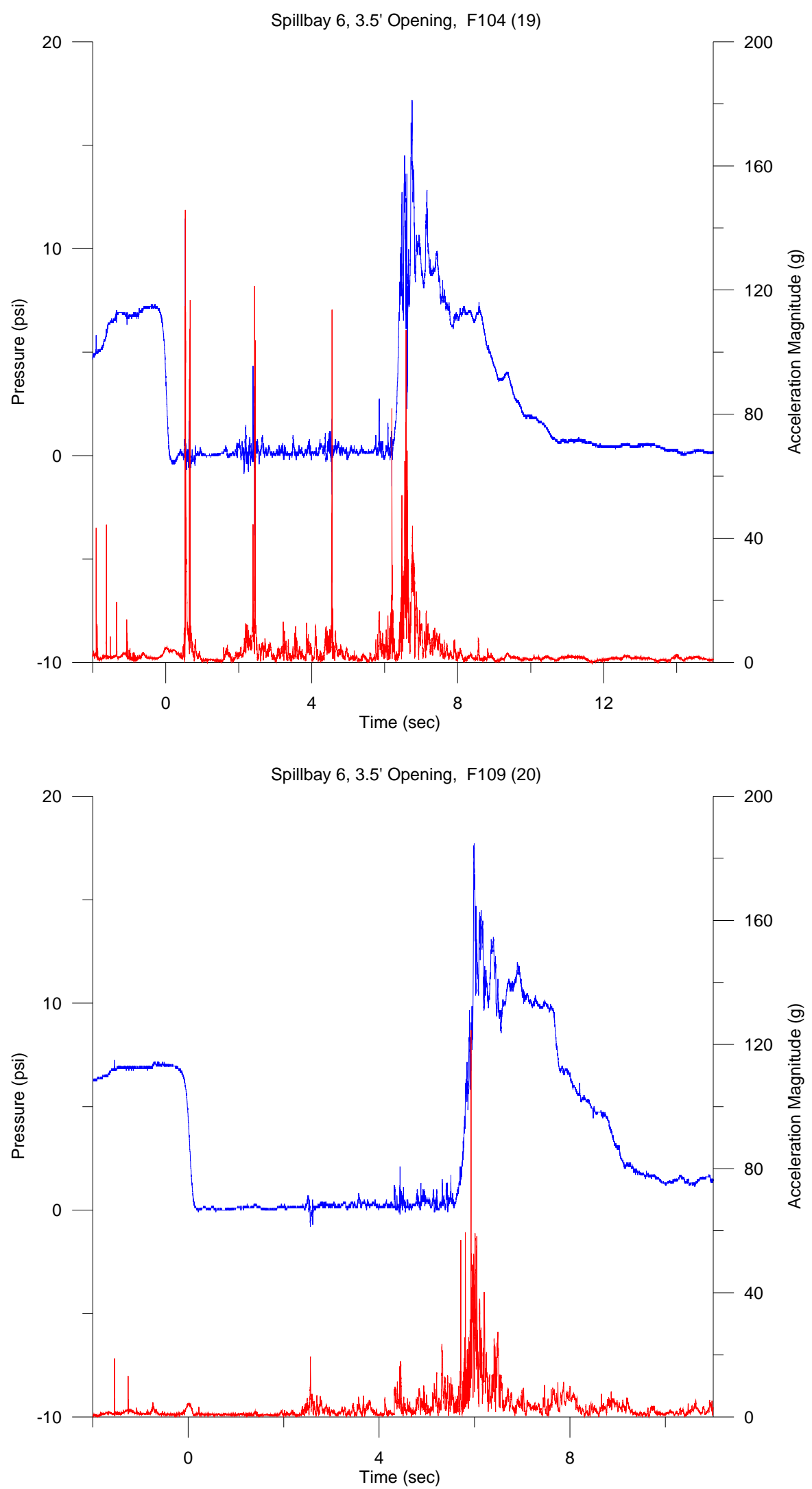

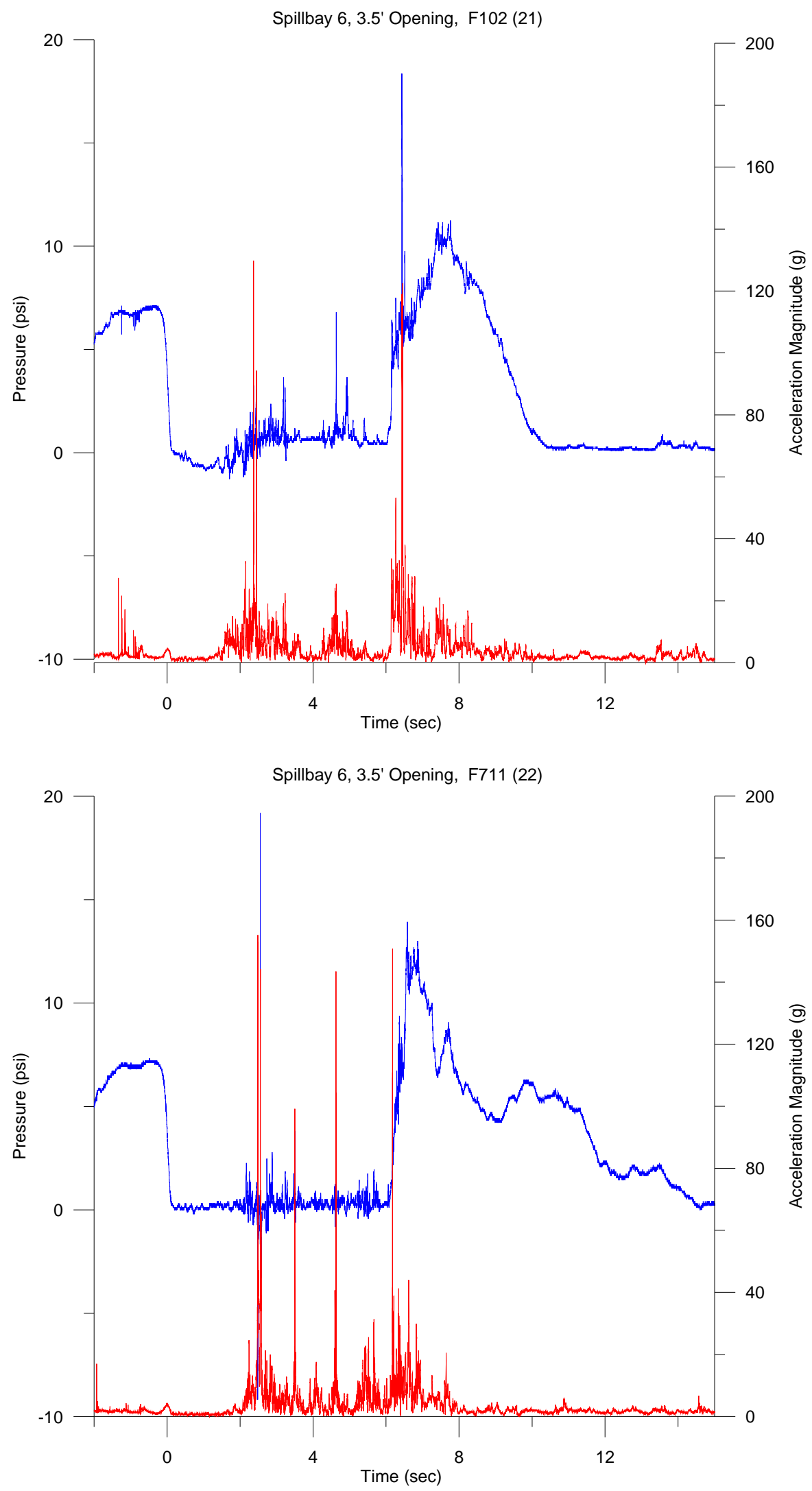

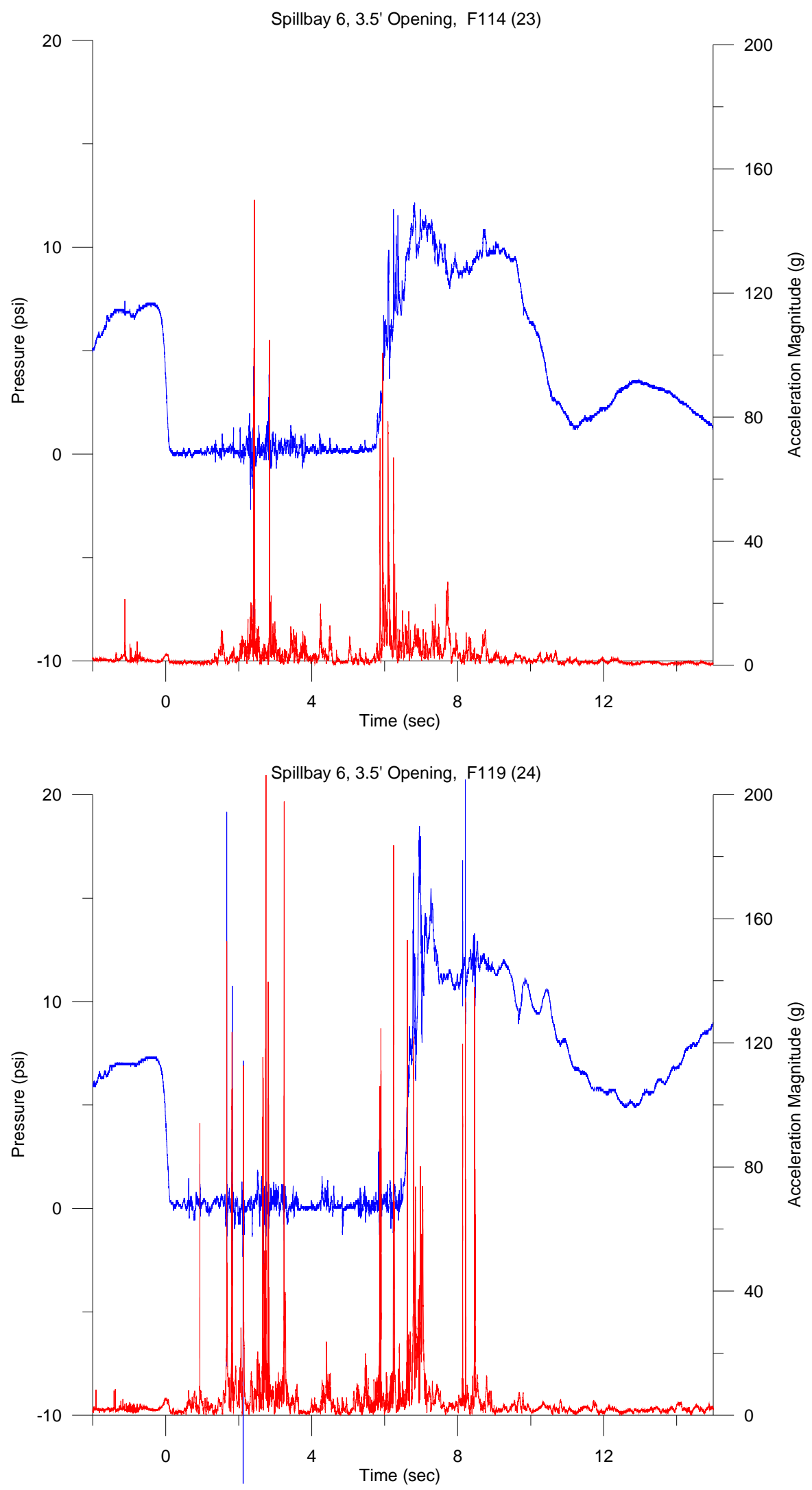
Appendix D

\section{Pressure and Angular Rate-of-Change Time Histories of Each Sensor Fish Release}


Spillbay 3, 1.5-ft Tainter Gate Opening 
Spillbay 3, 1.5' Opening, Pre-Test F114

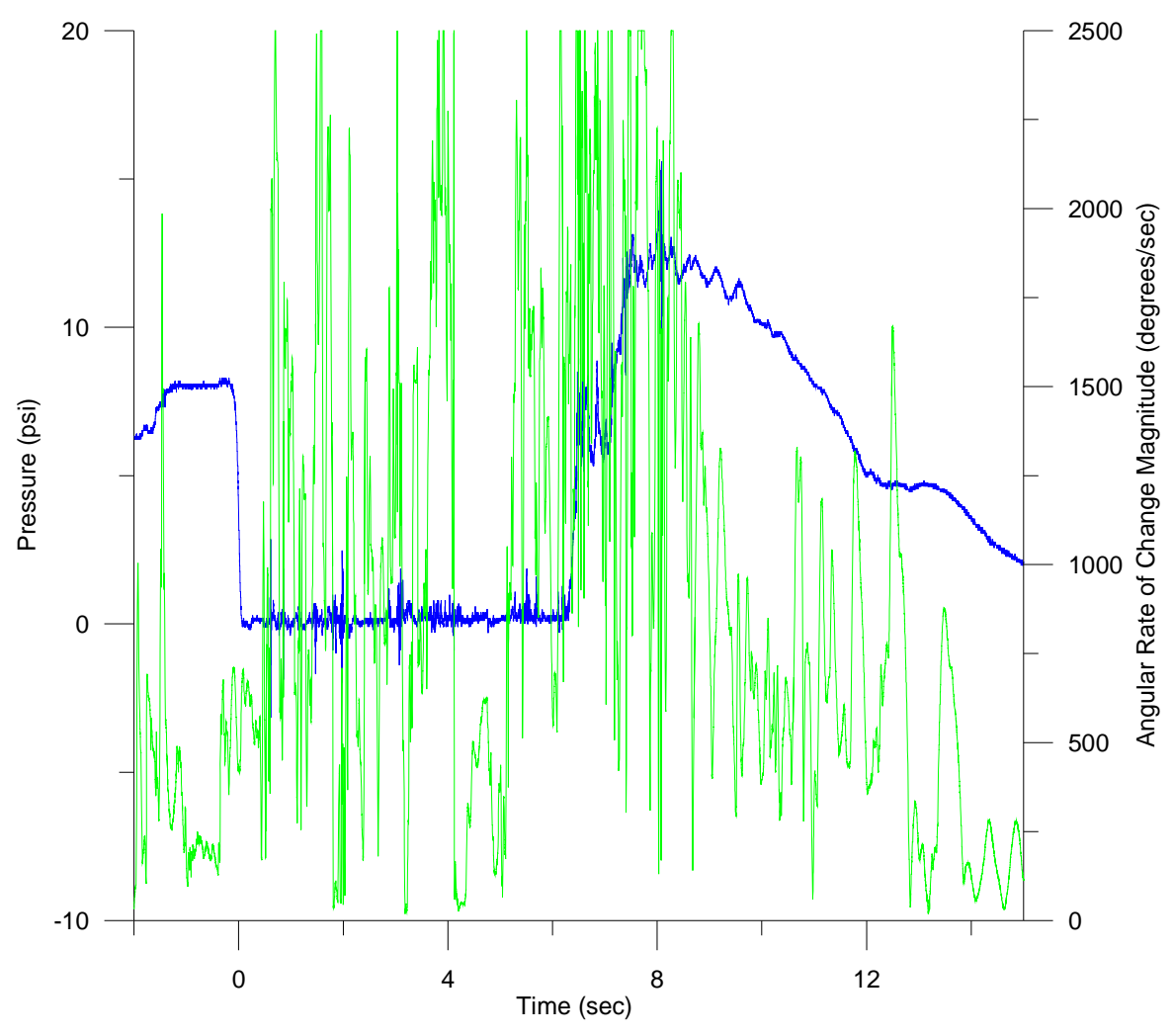

D.1 

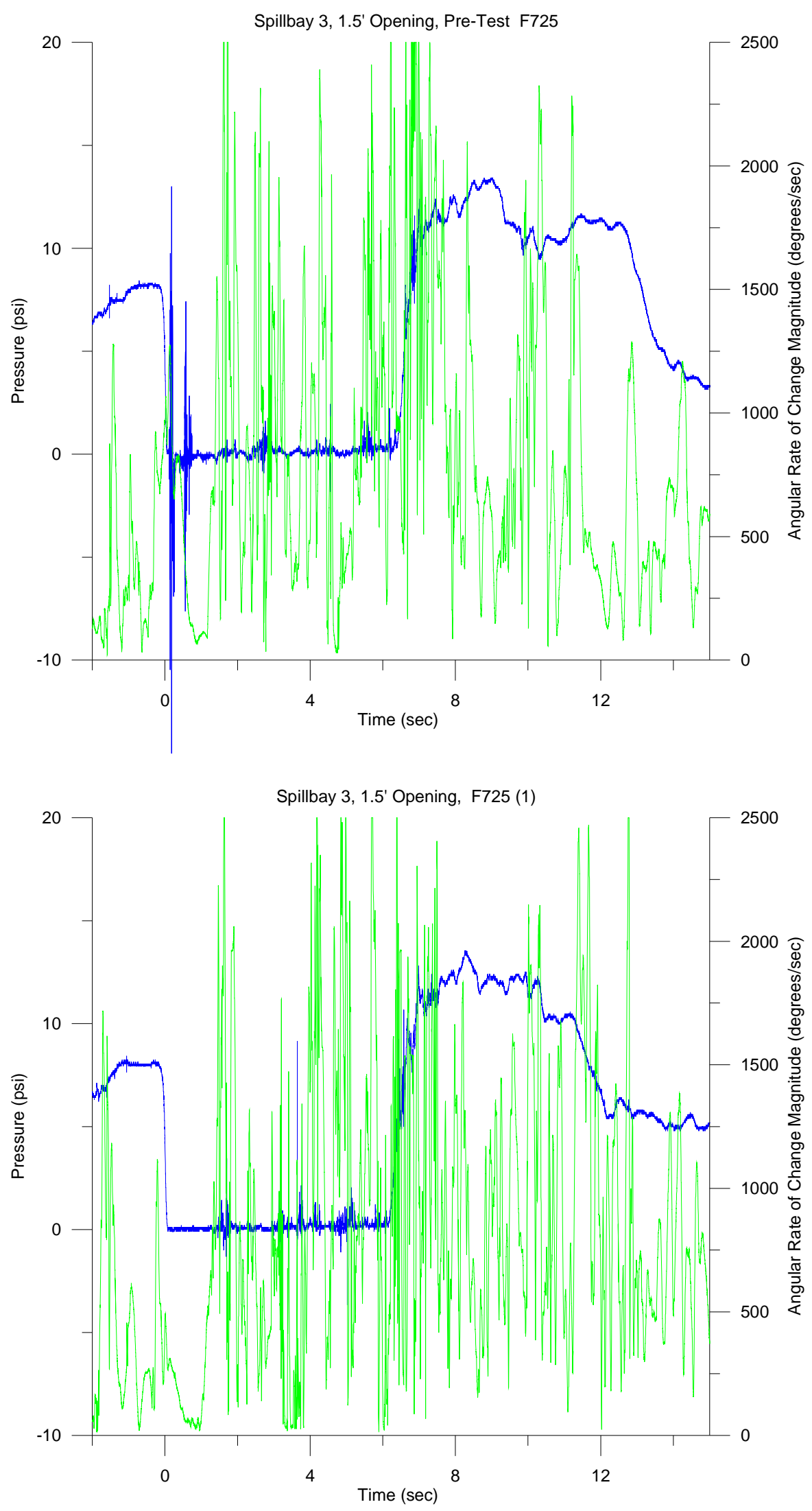

D. 2 

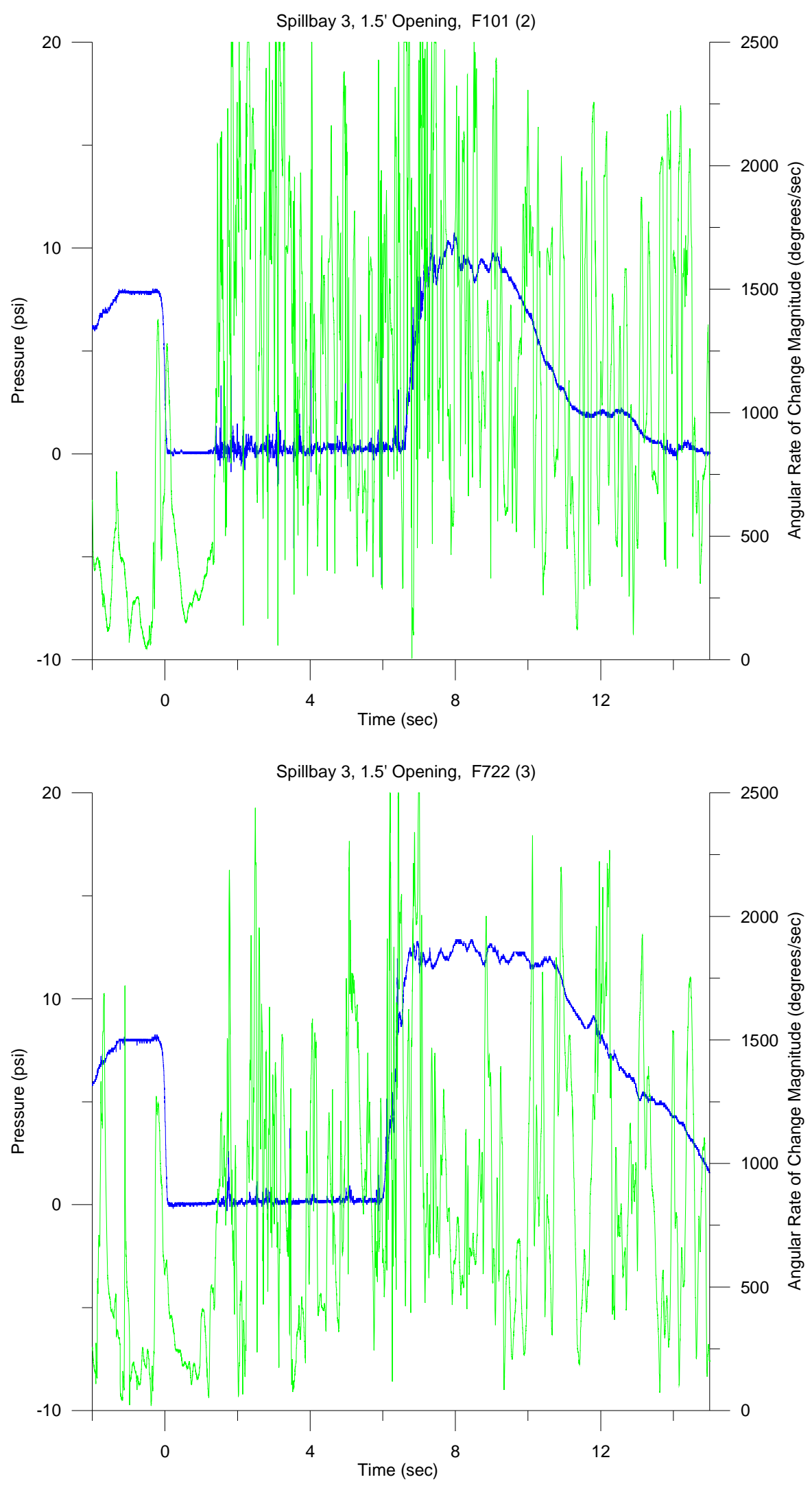

D. 3 

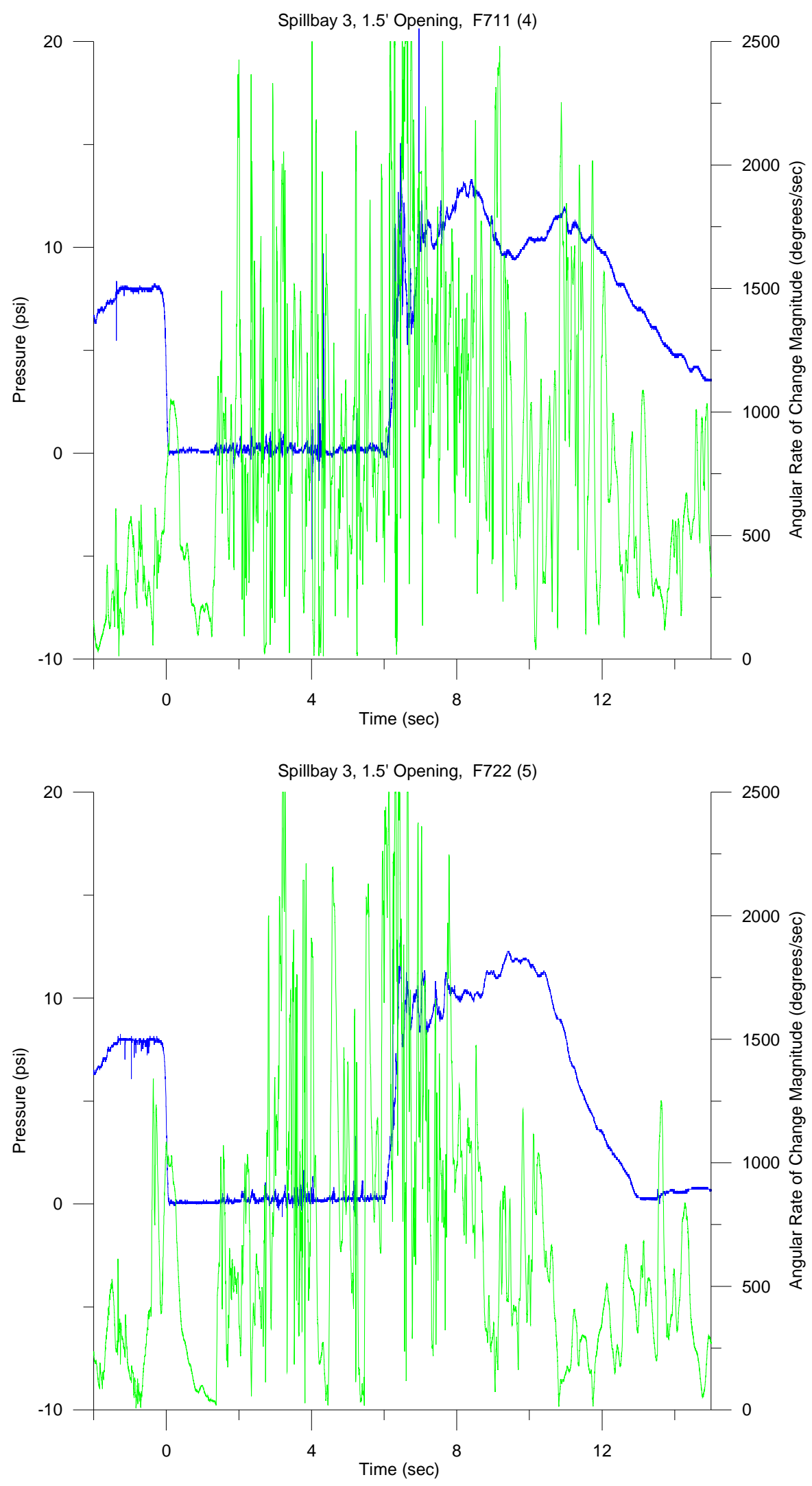

D. 4 

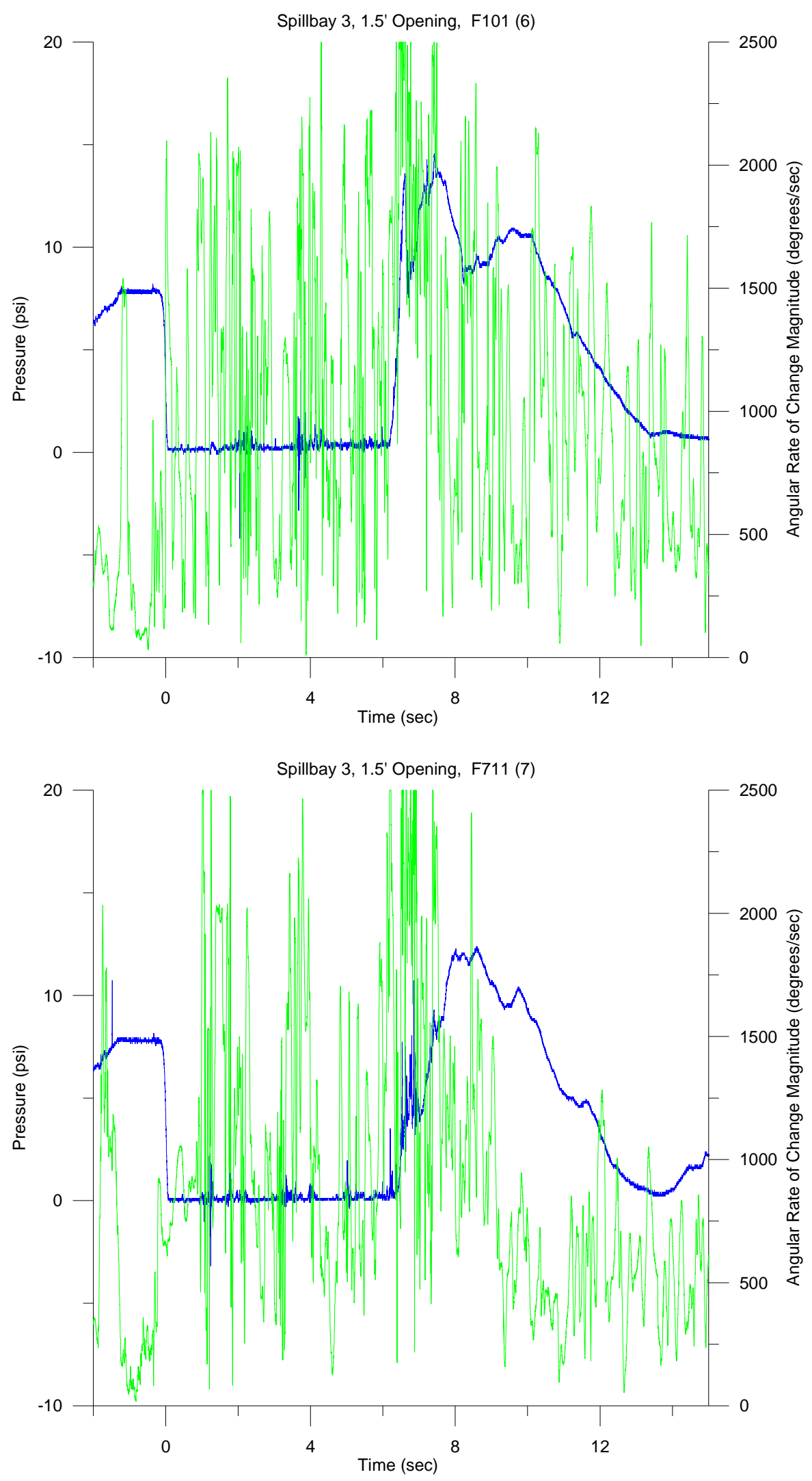

D. 5 

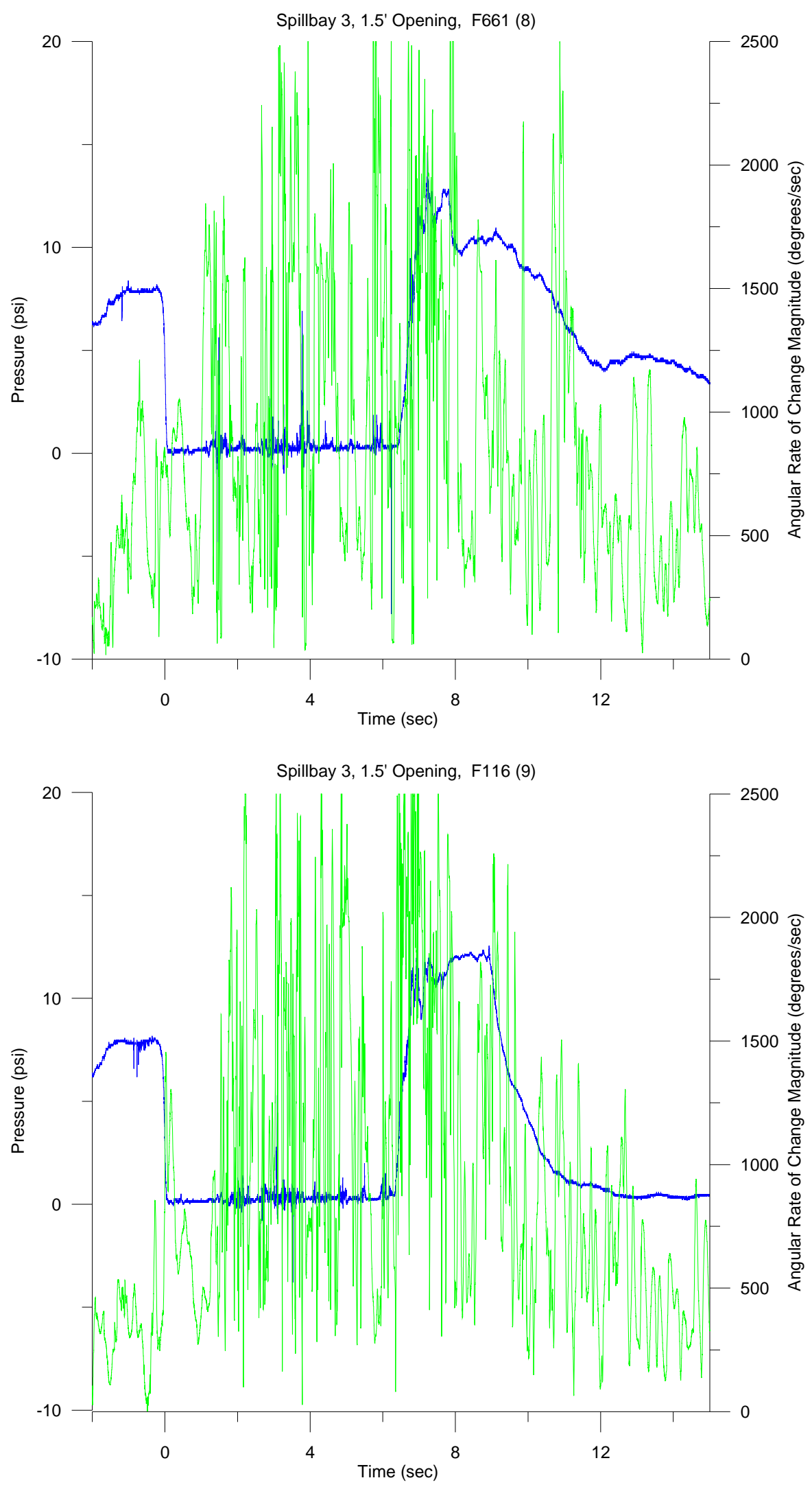

D. 6 

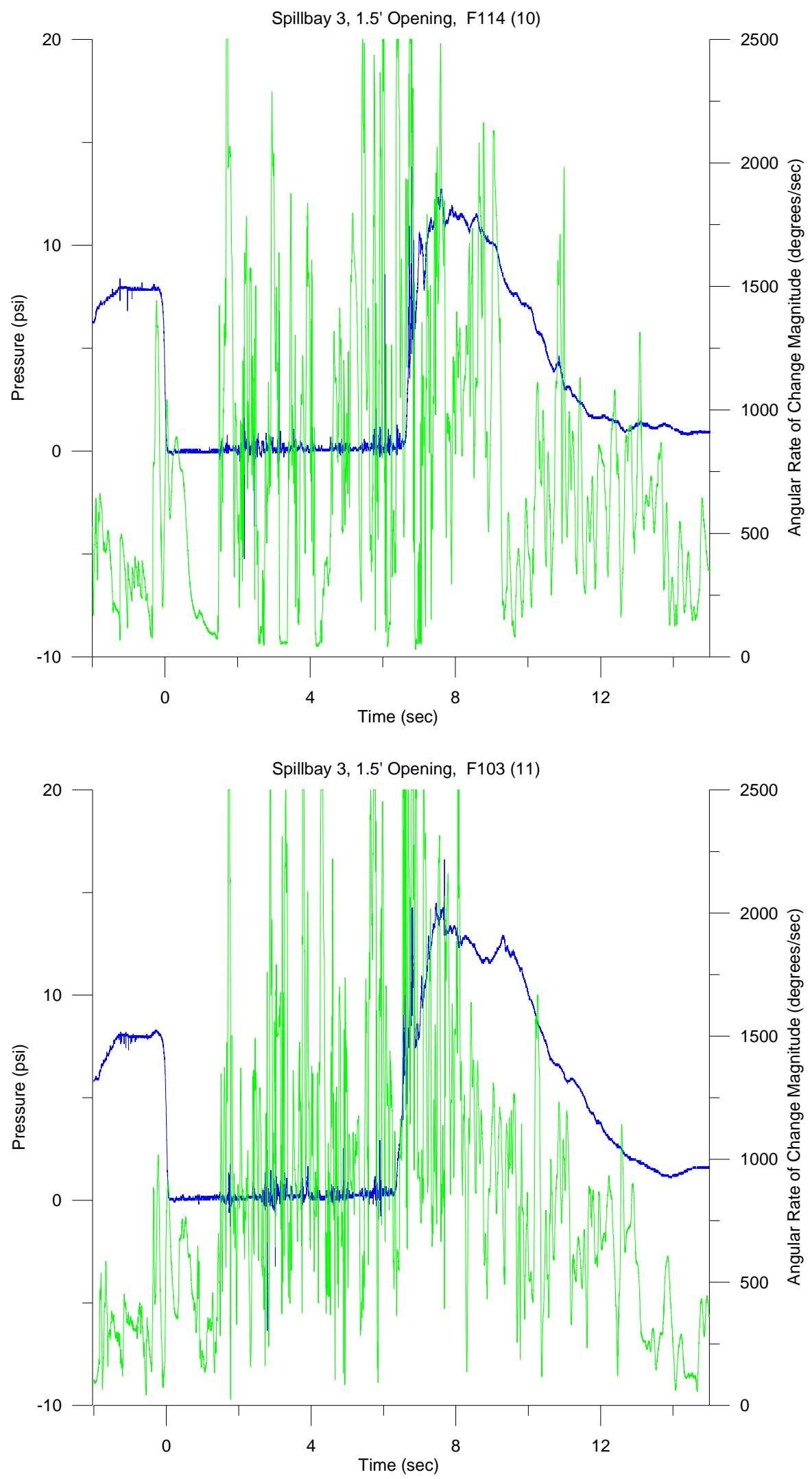

D.7 

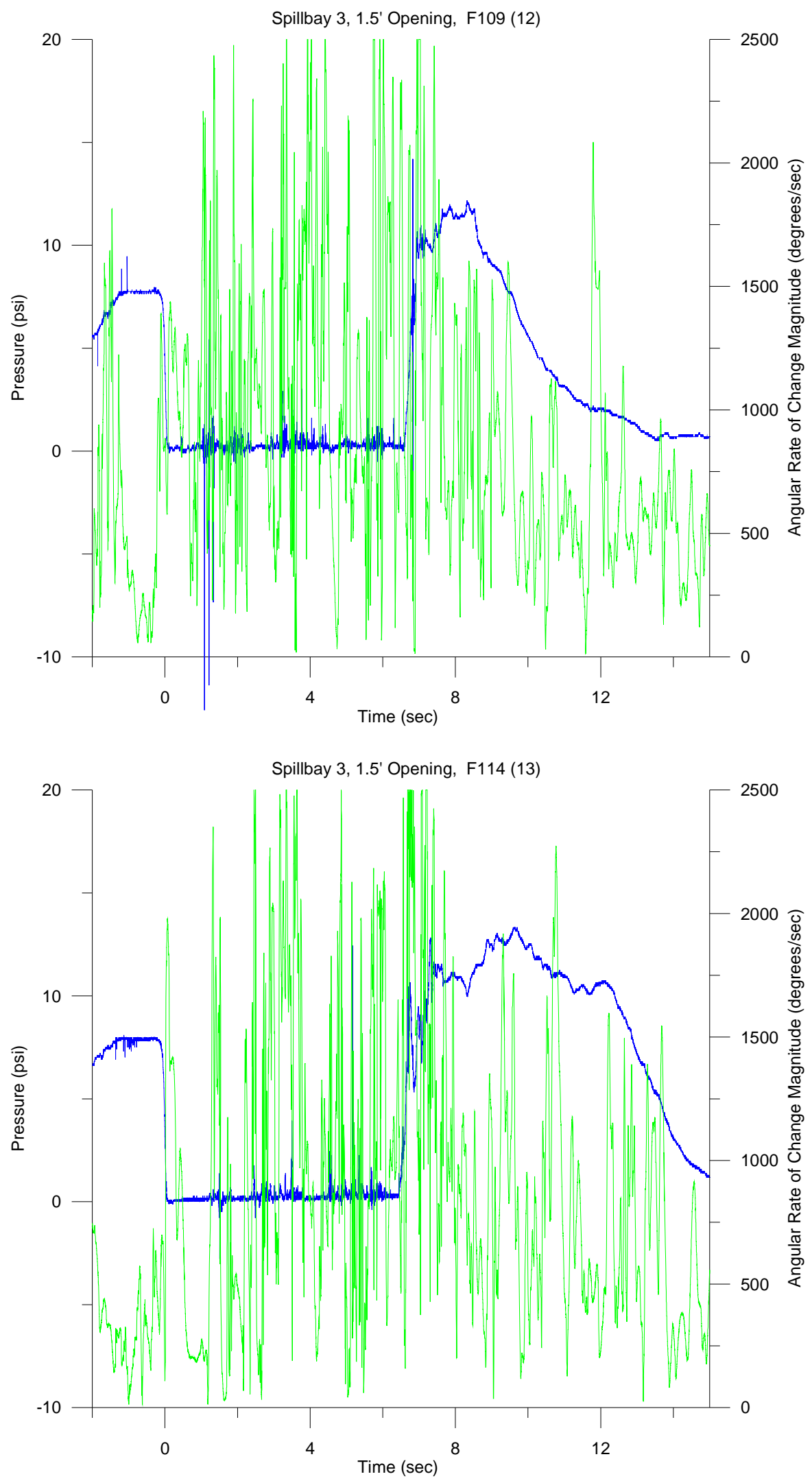

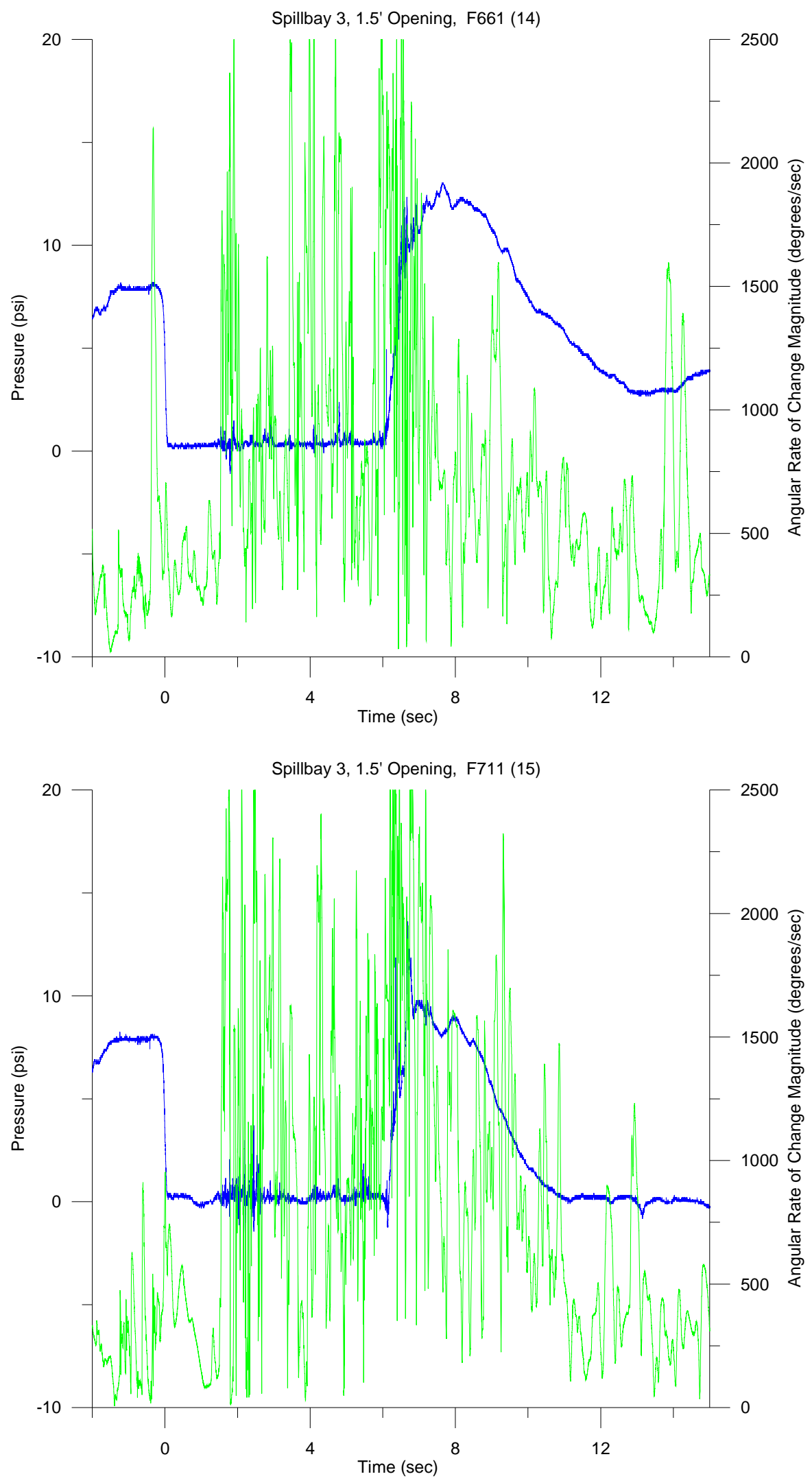

D.9 

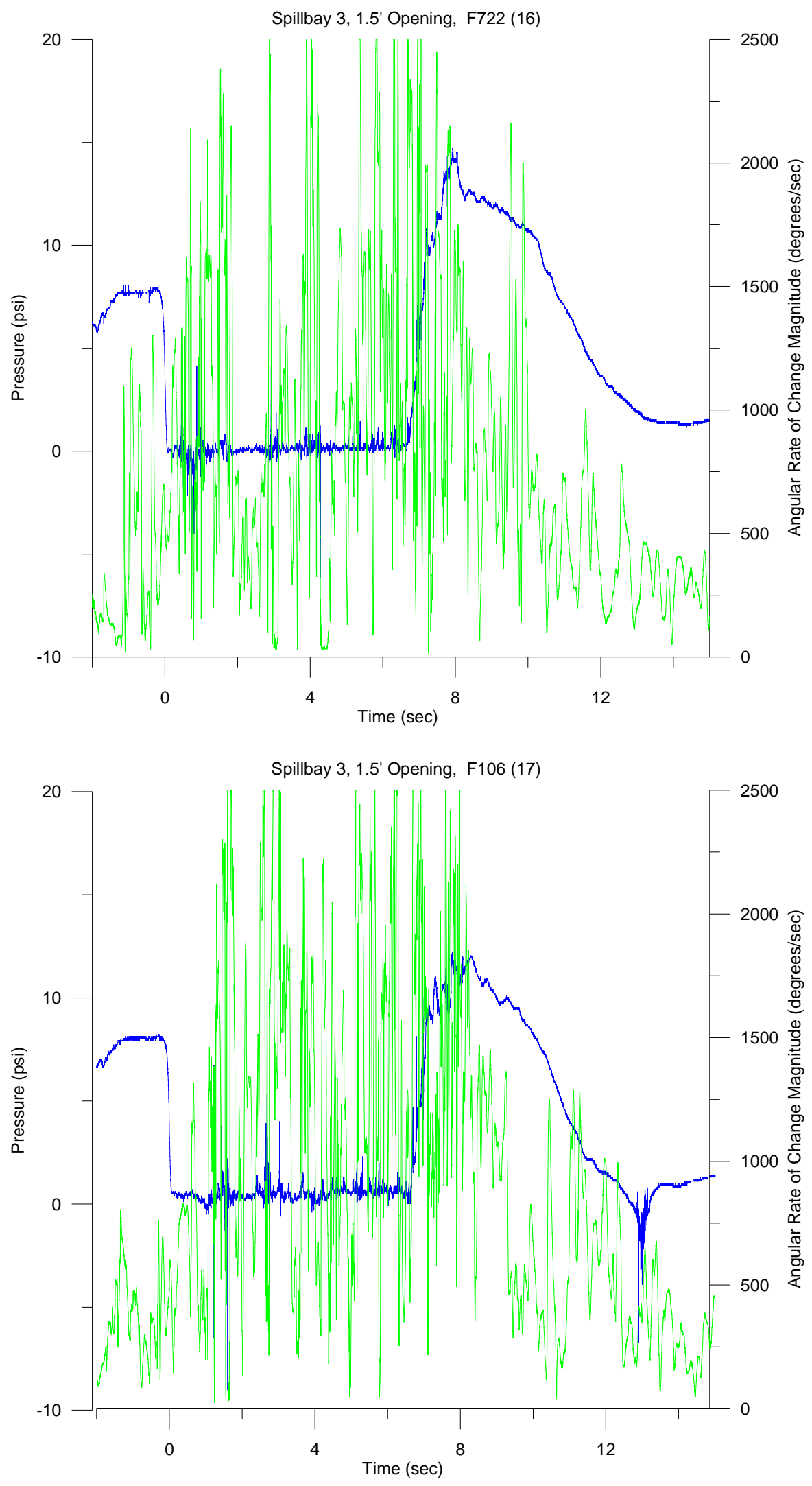

D.10 

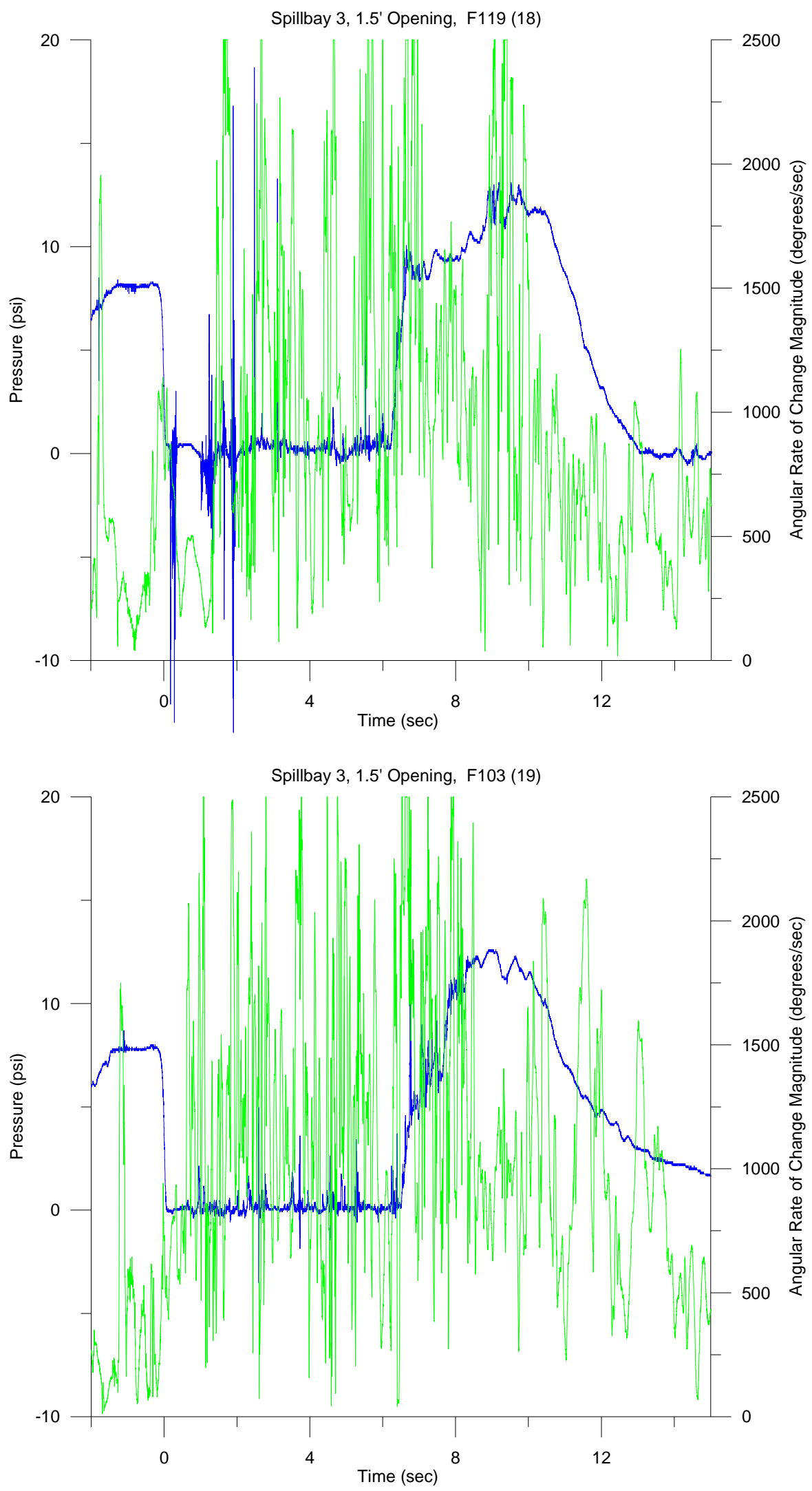

D.11 

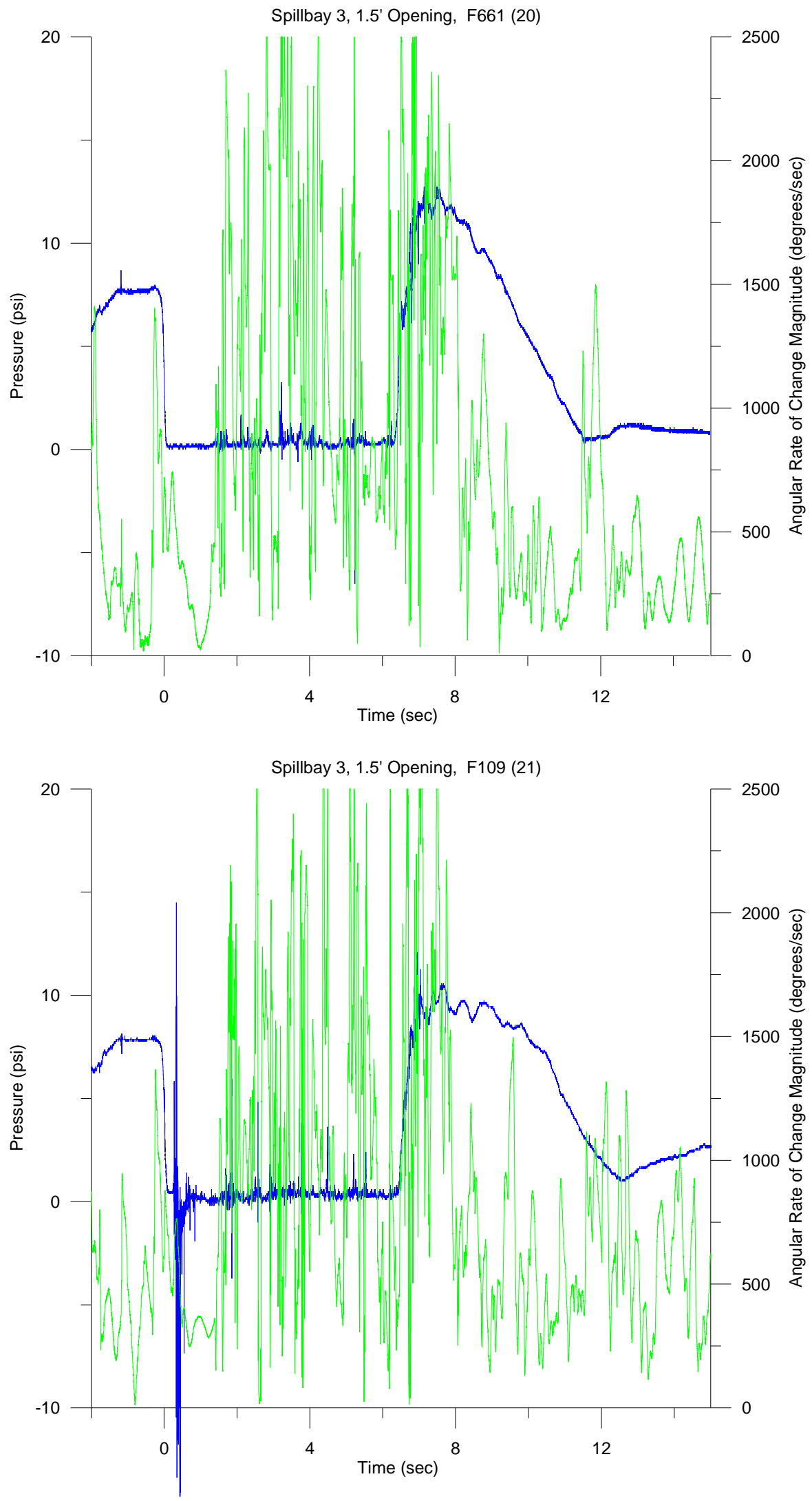

D.12 


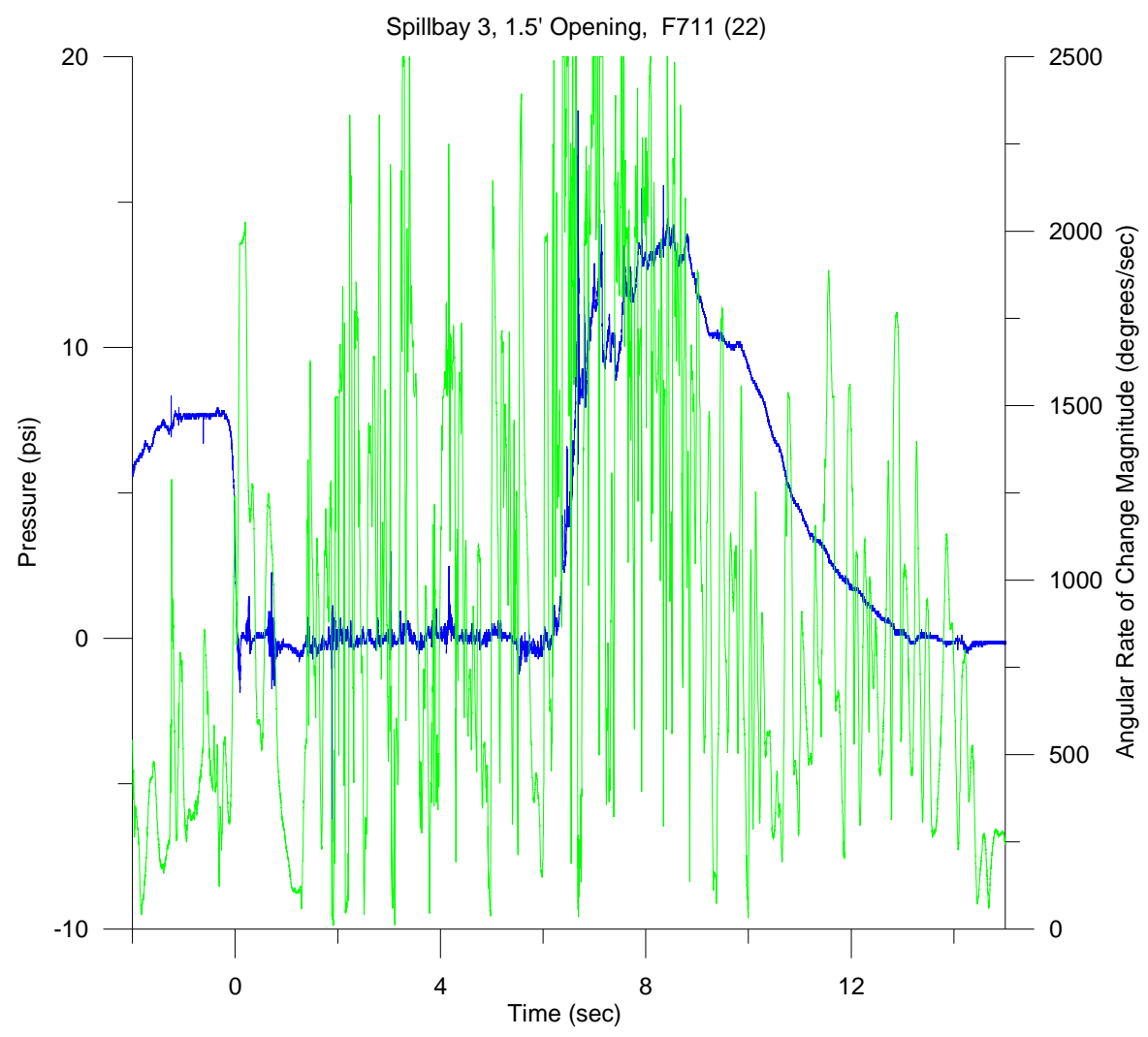

D.13 


\section{Spillbay 3, 3.5-ft Tainter Gate Opening}



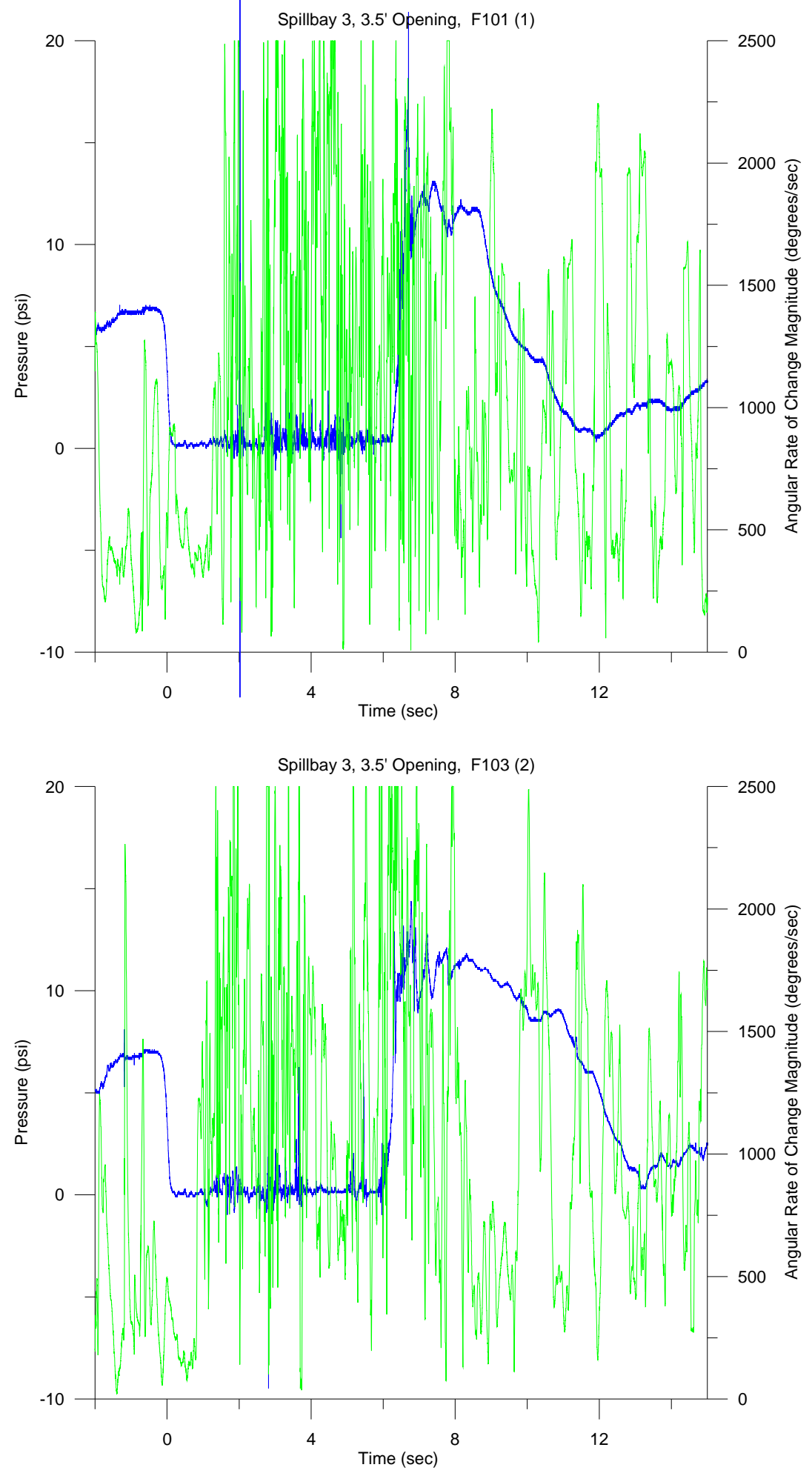

D.17 

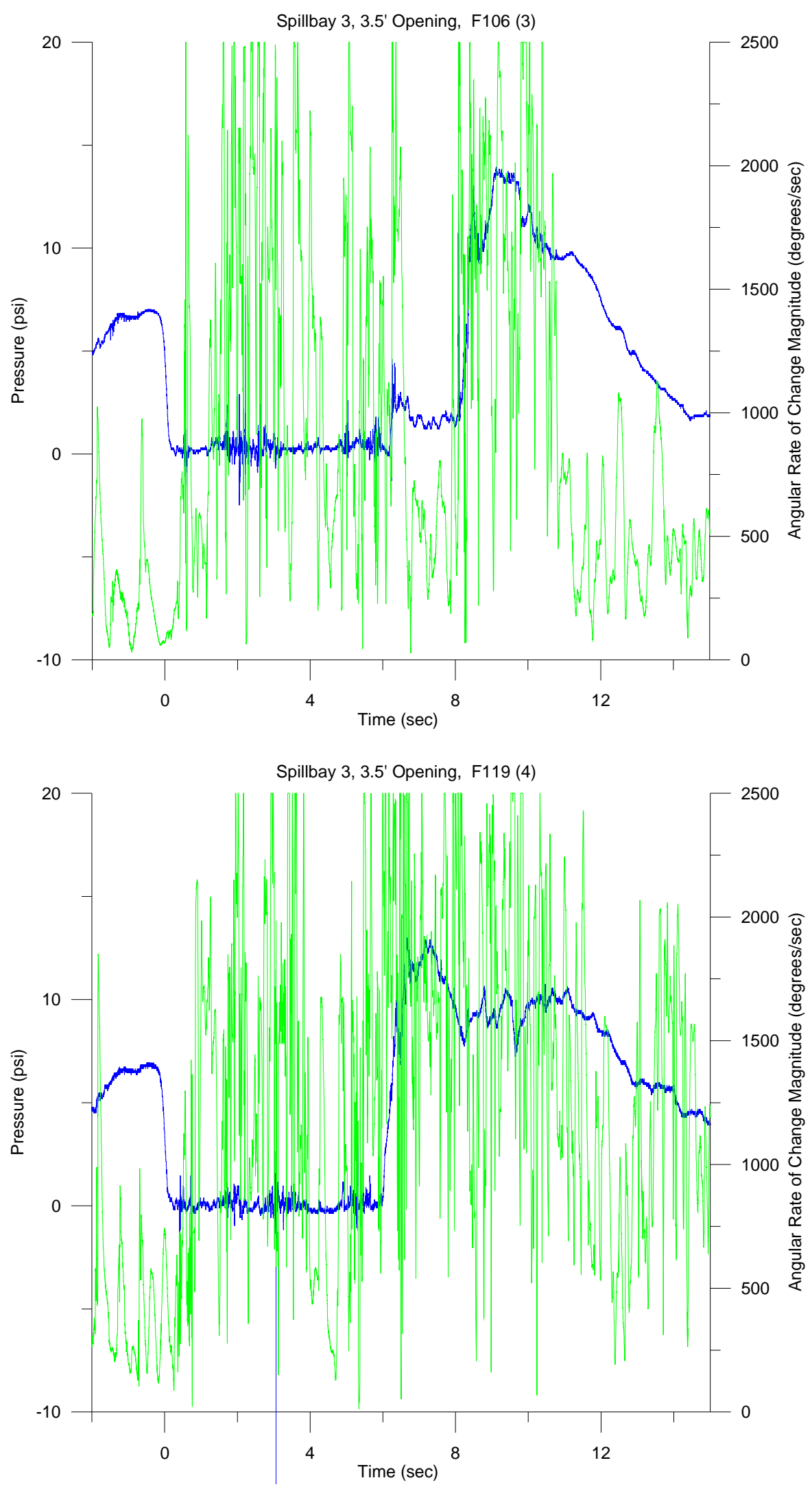

D.18 

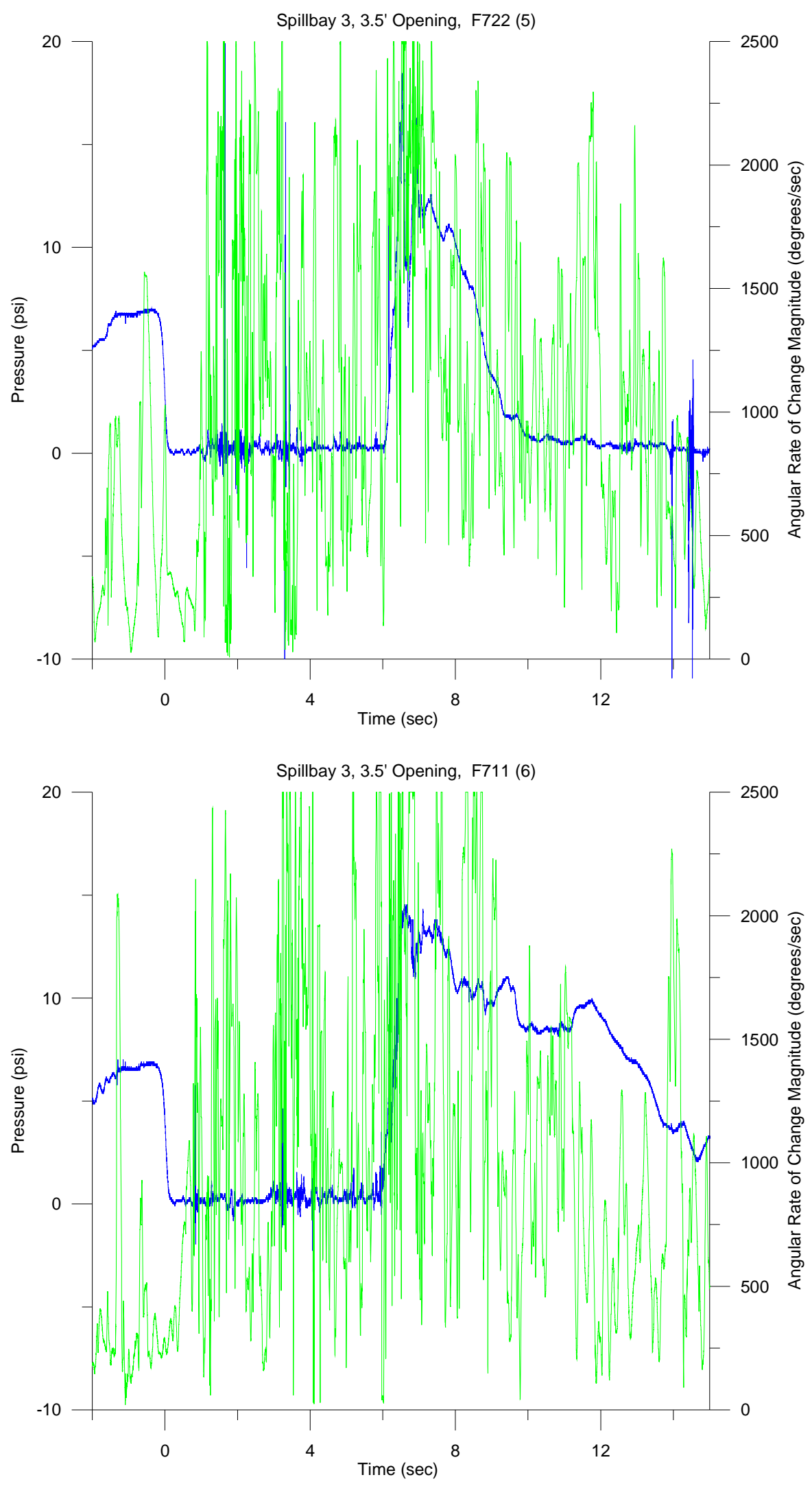

D.19 


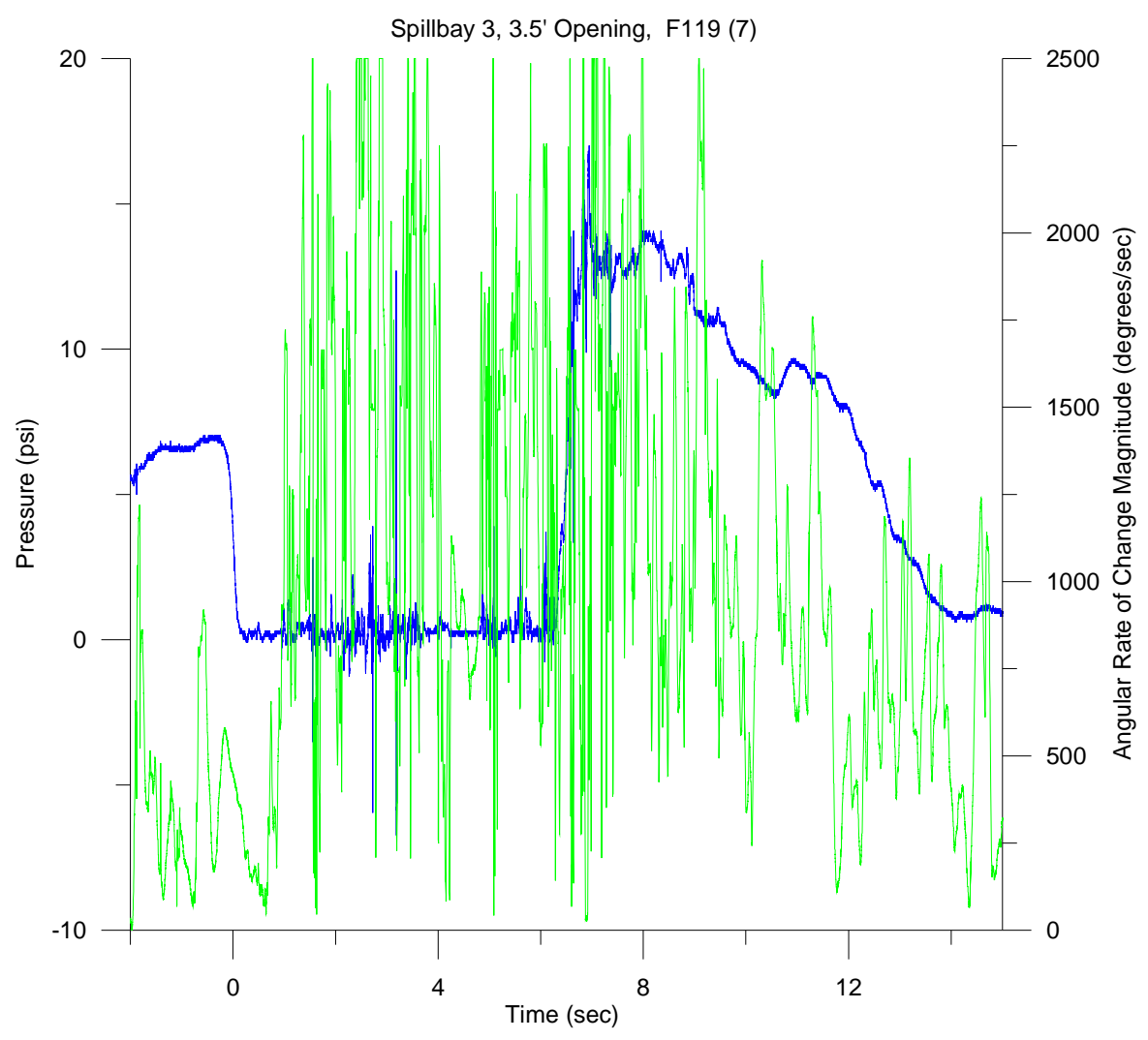




\section{Spillbay 6, 1.5-ft Tainter Gate Opening}



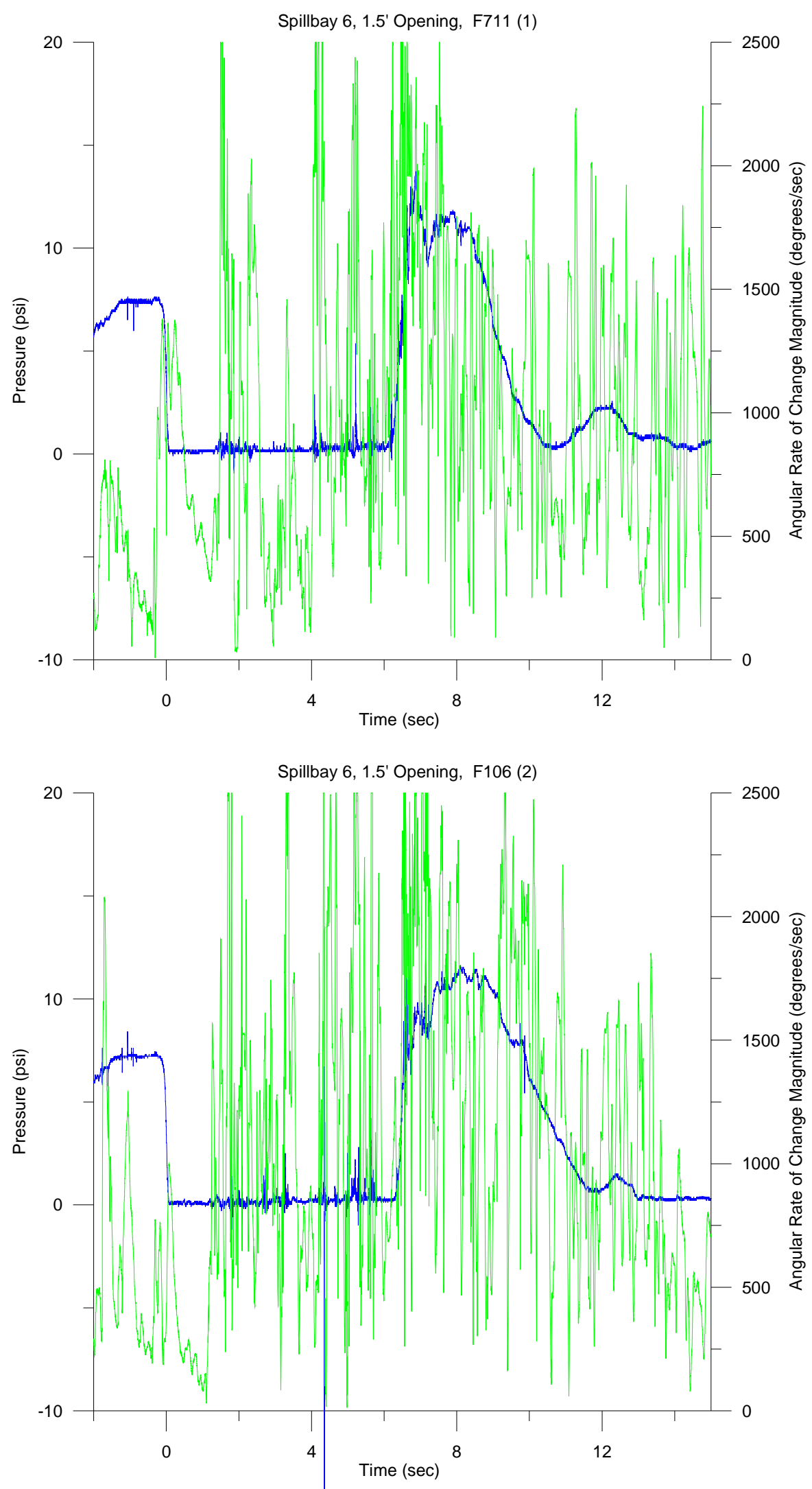

D.23 

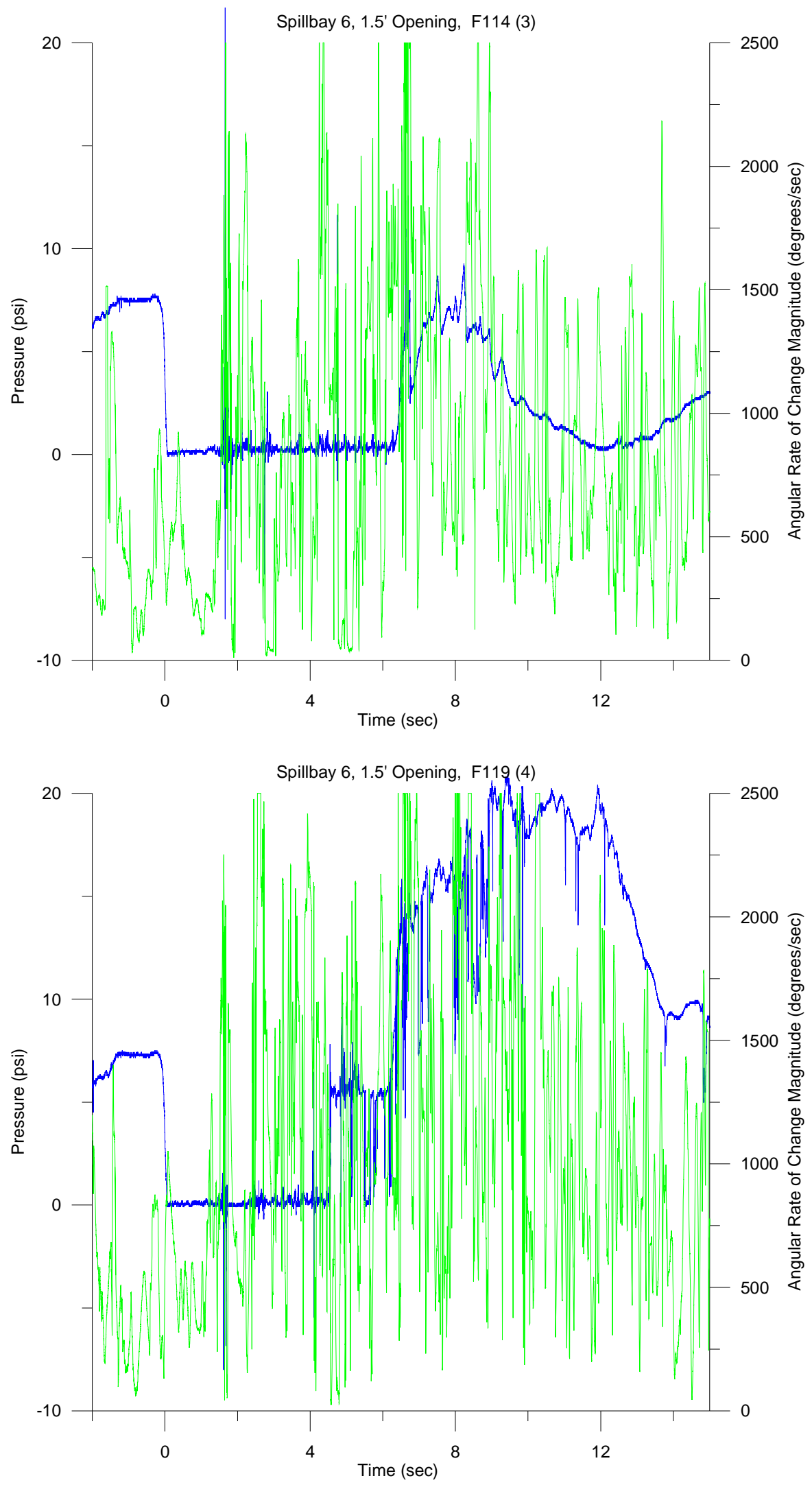

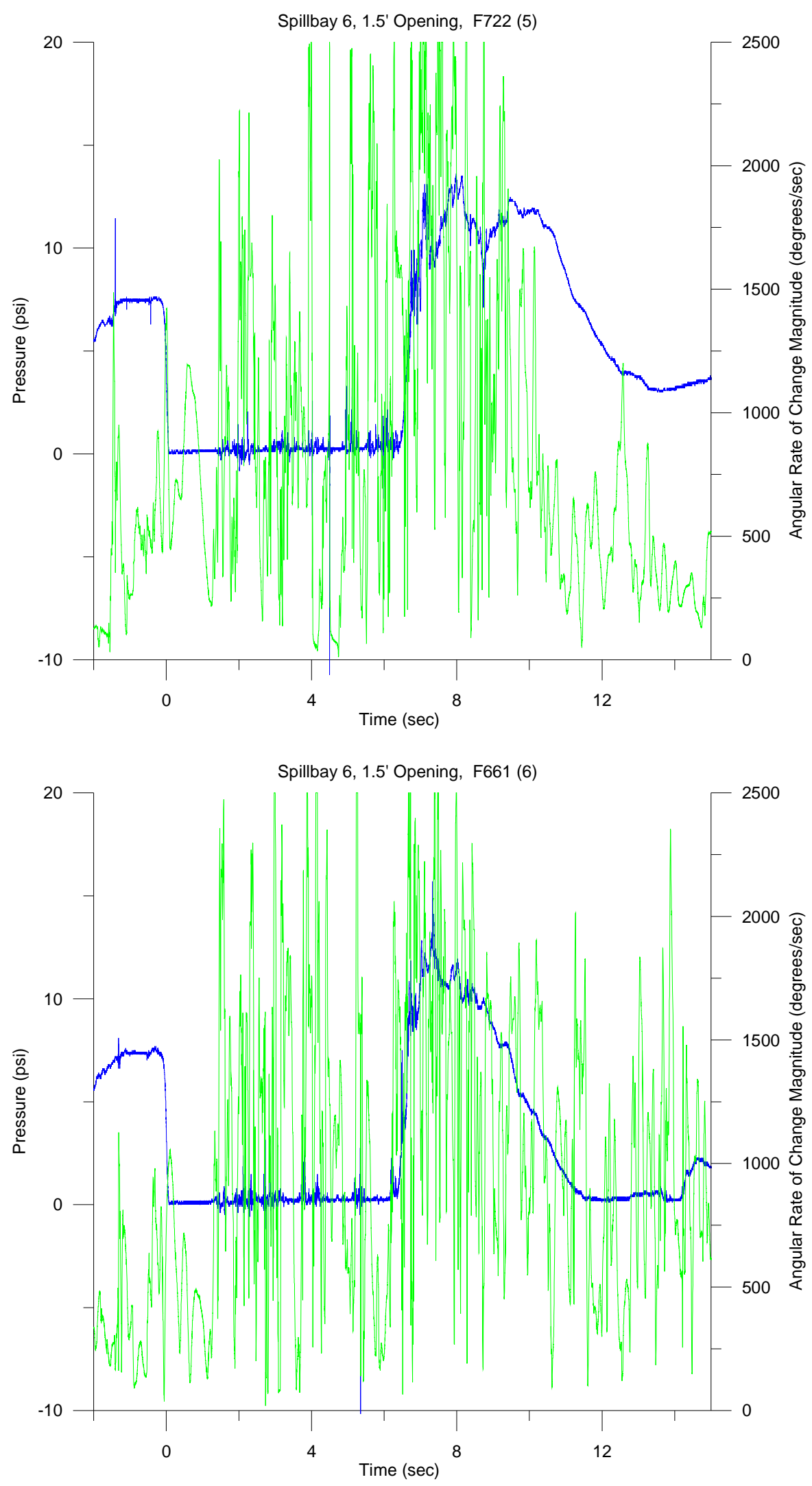

D.25 

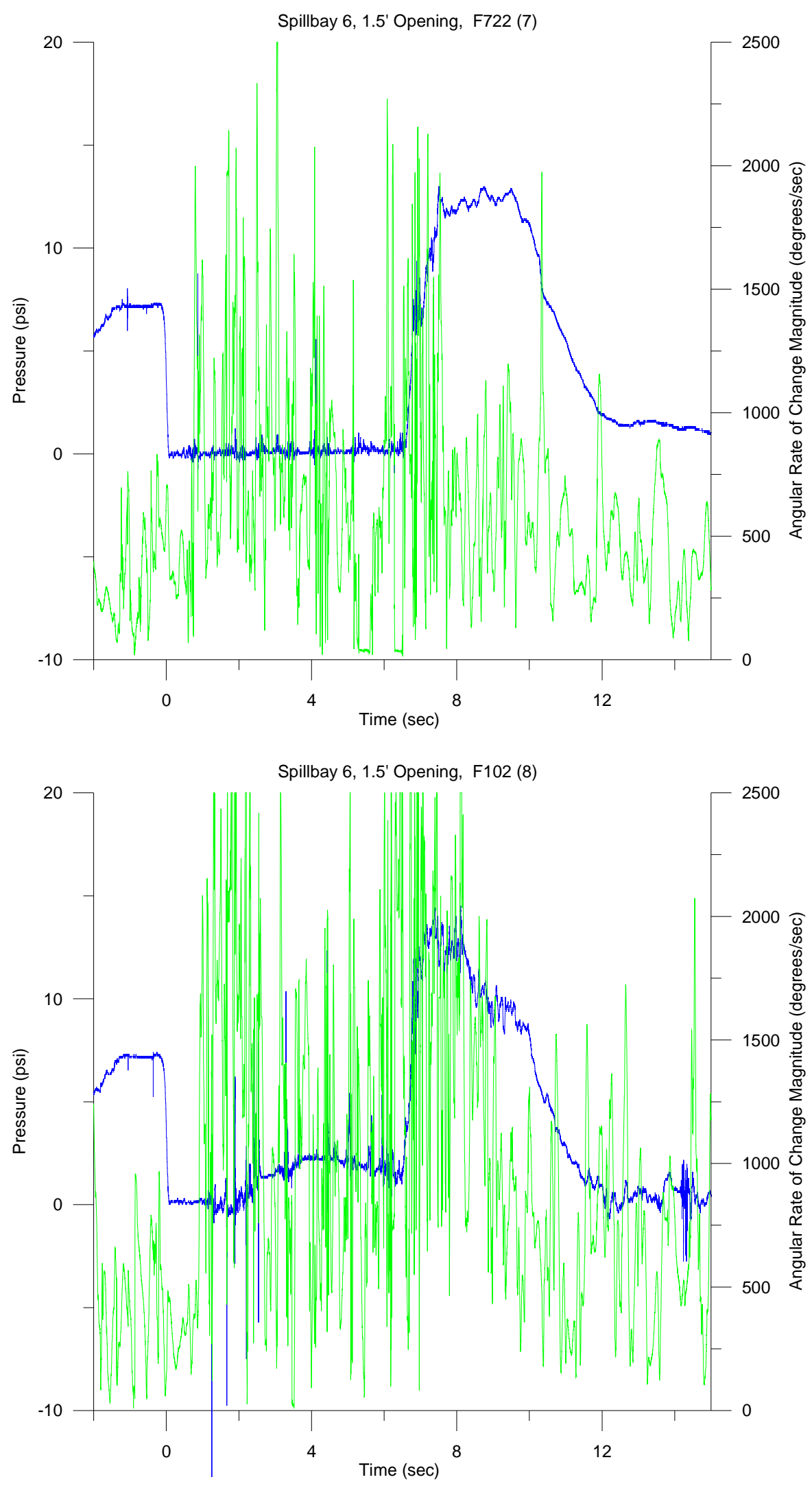

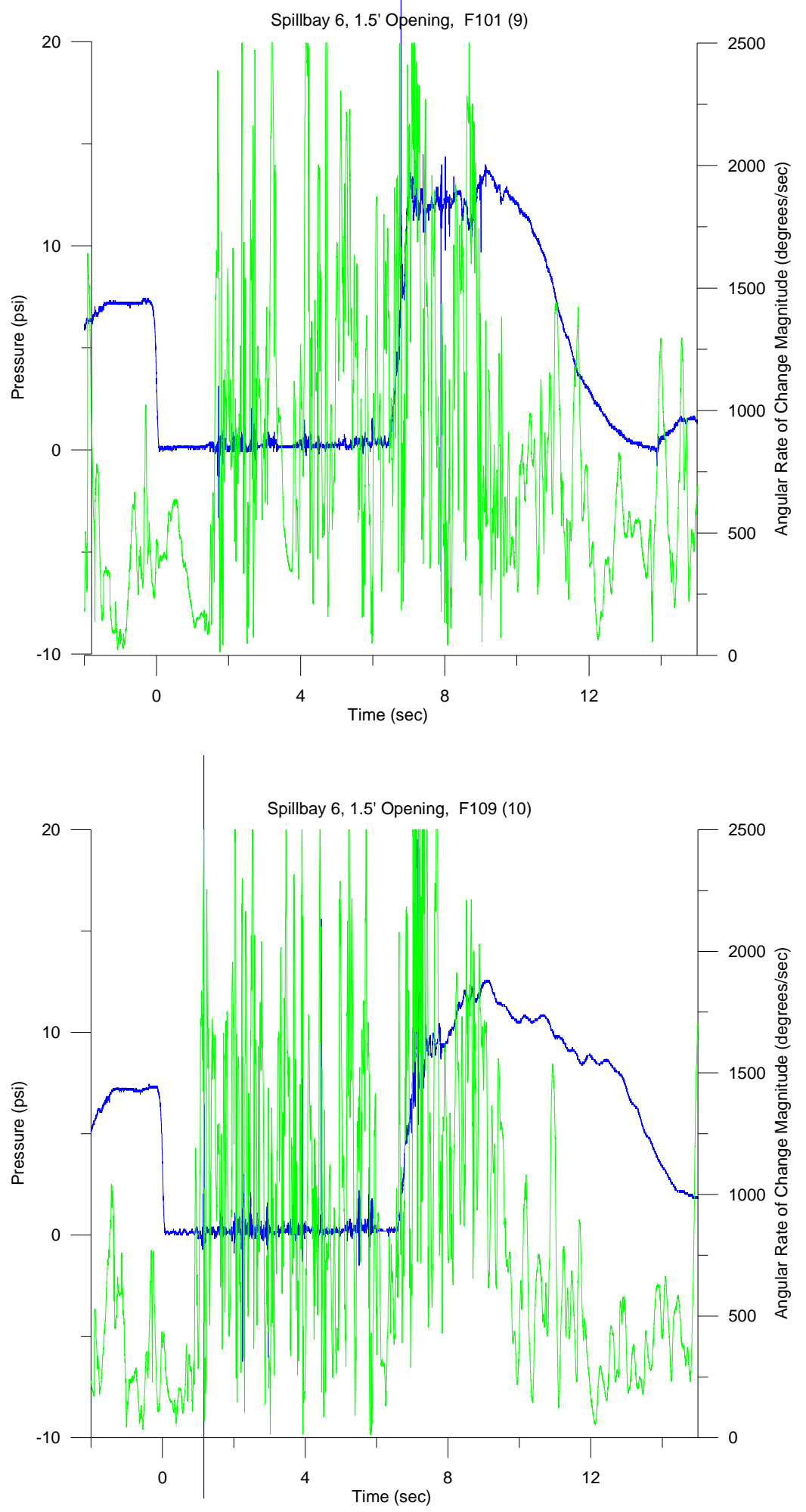

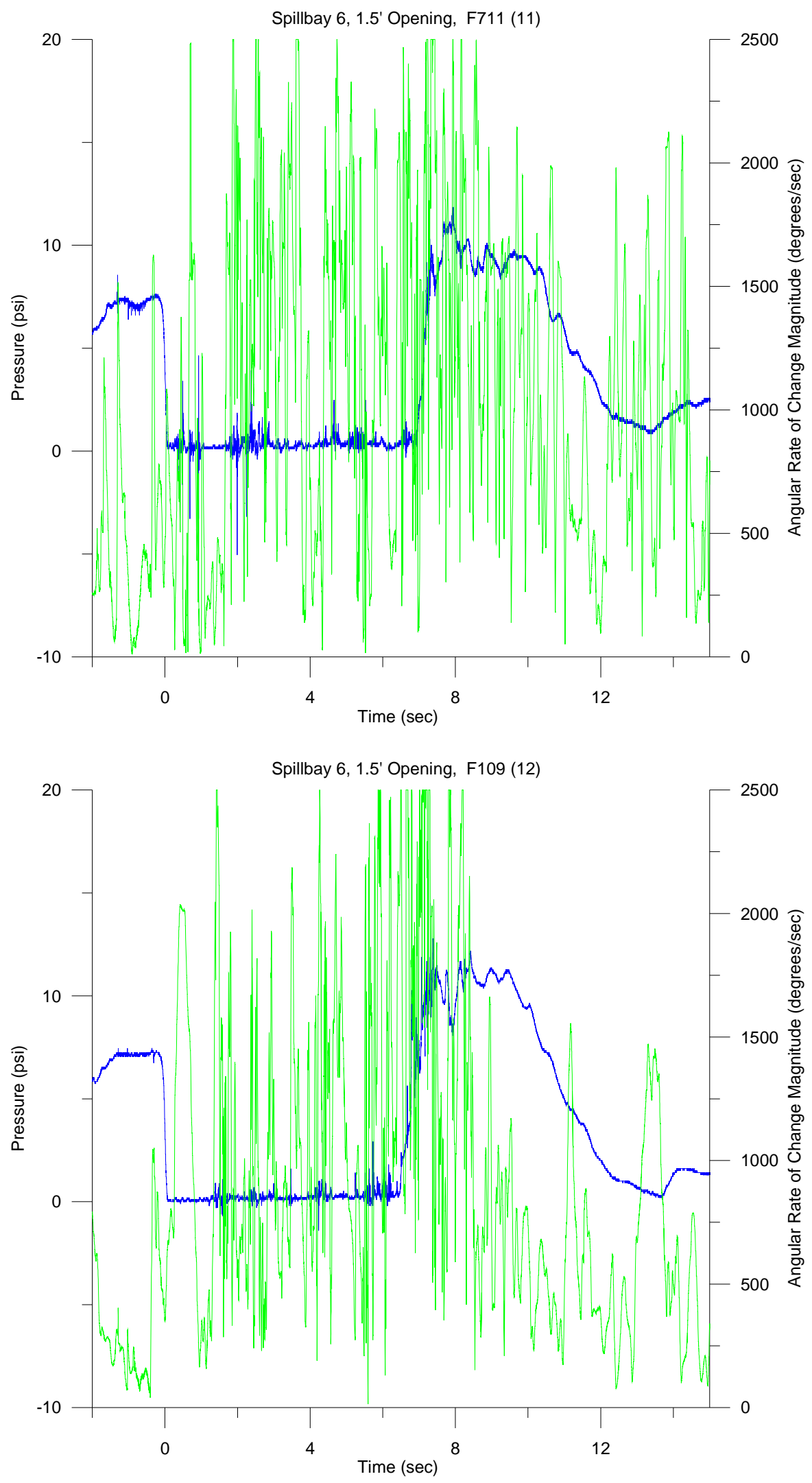

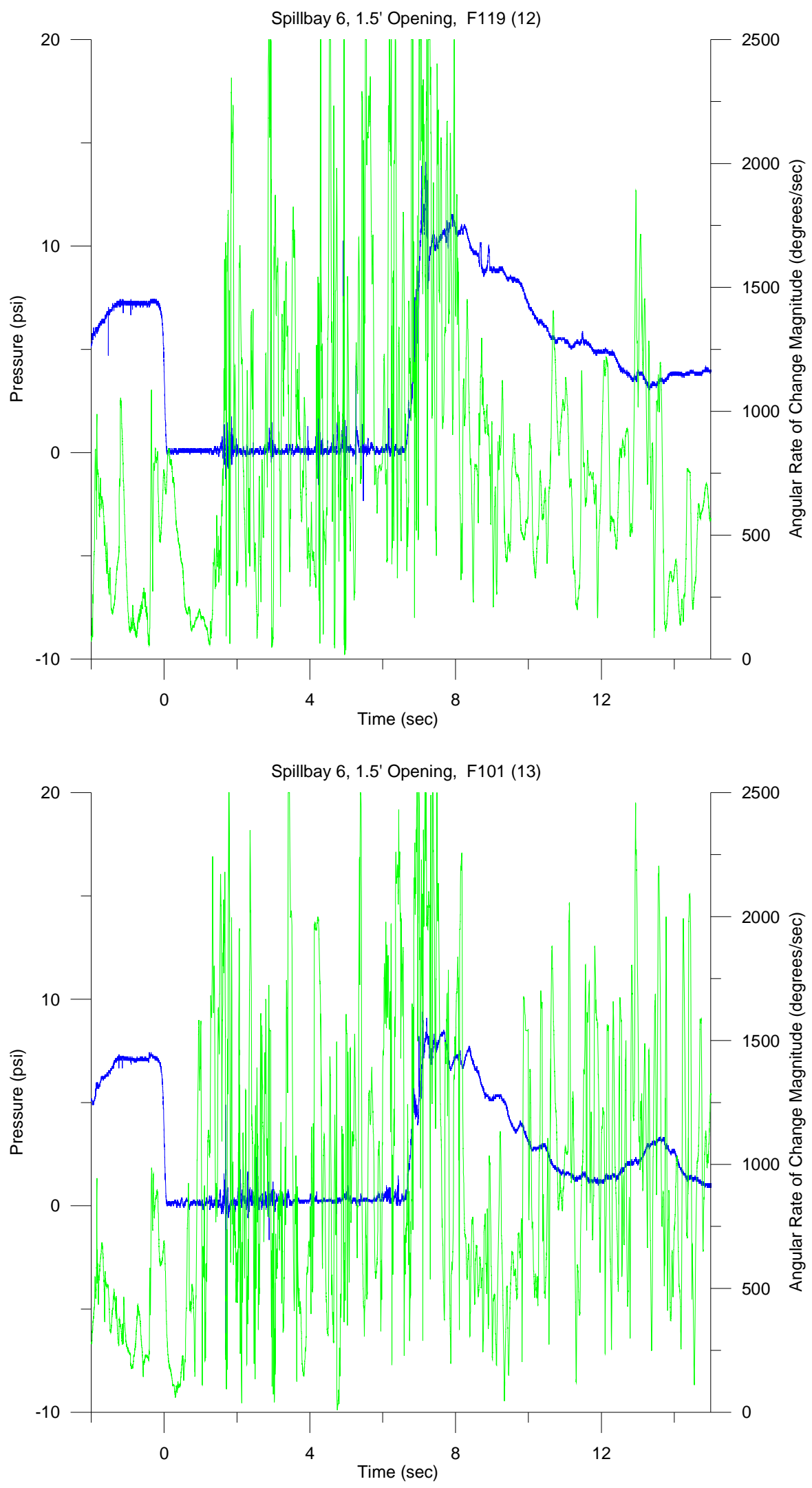

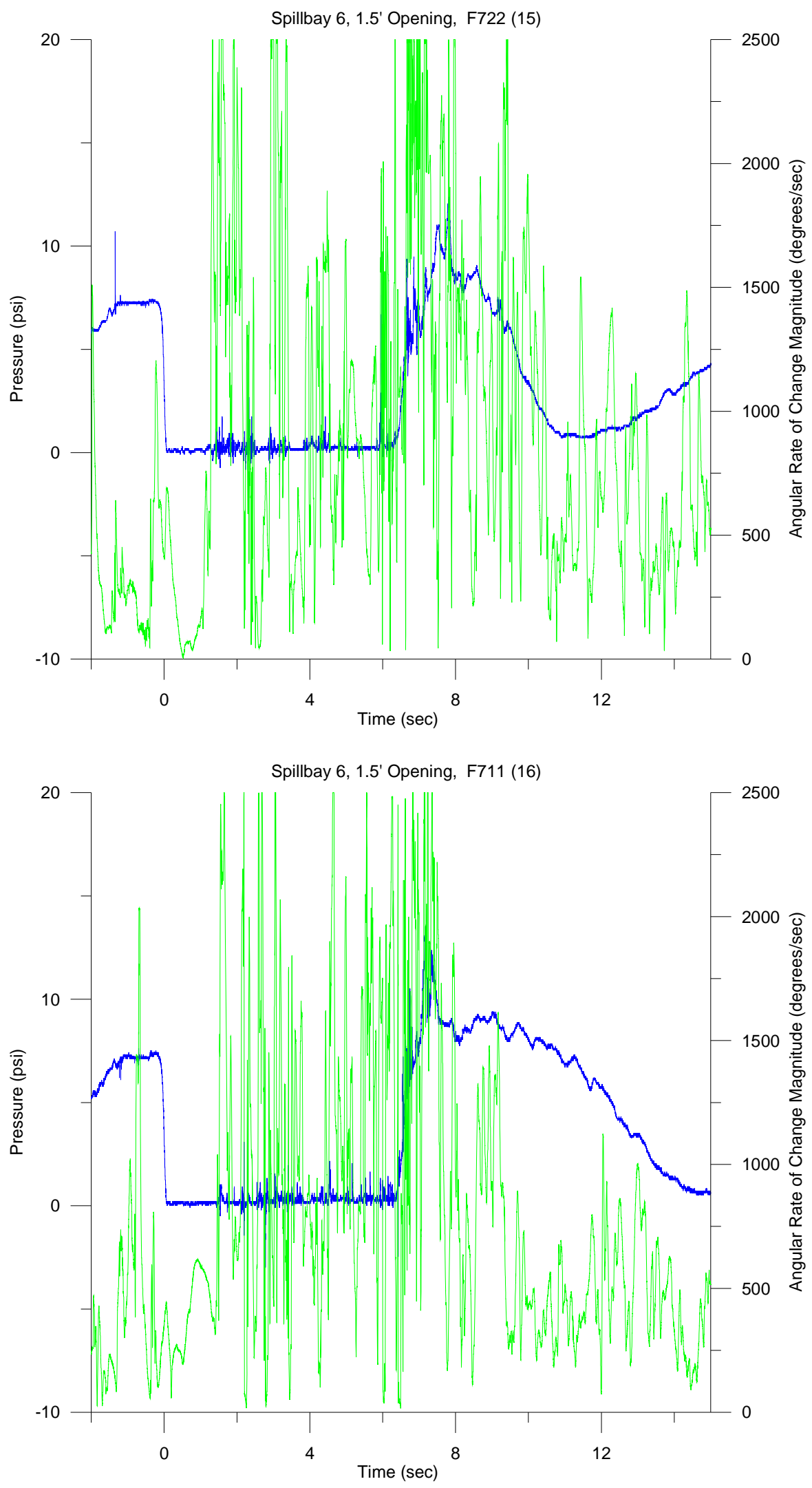

D.30 


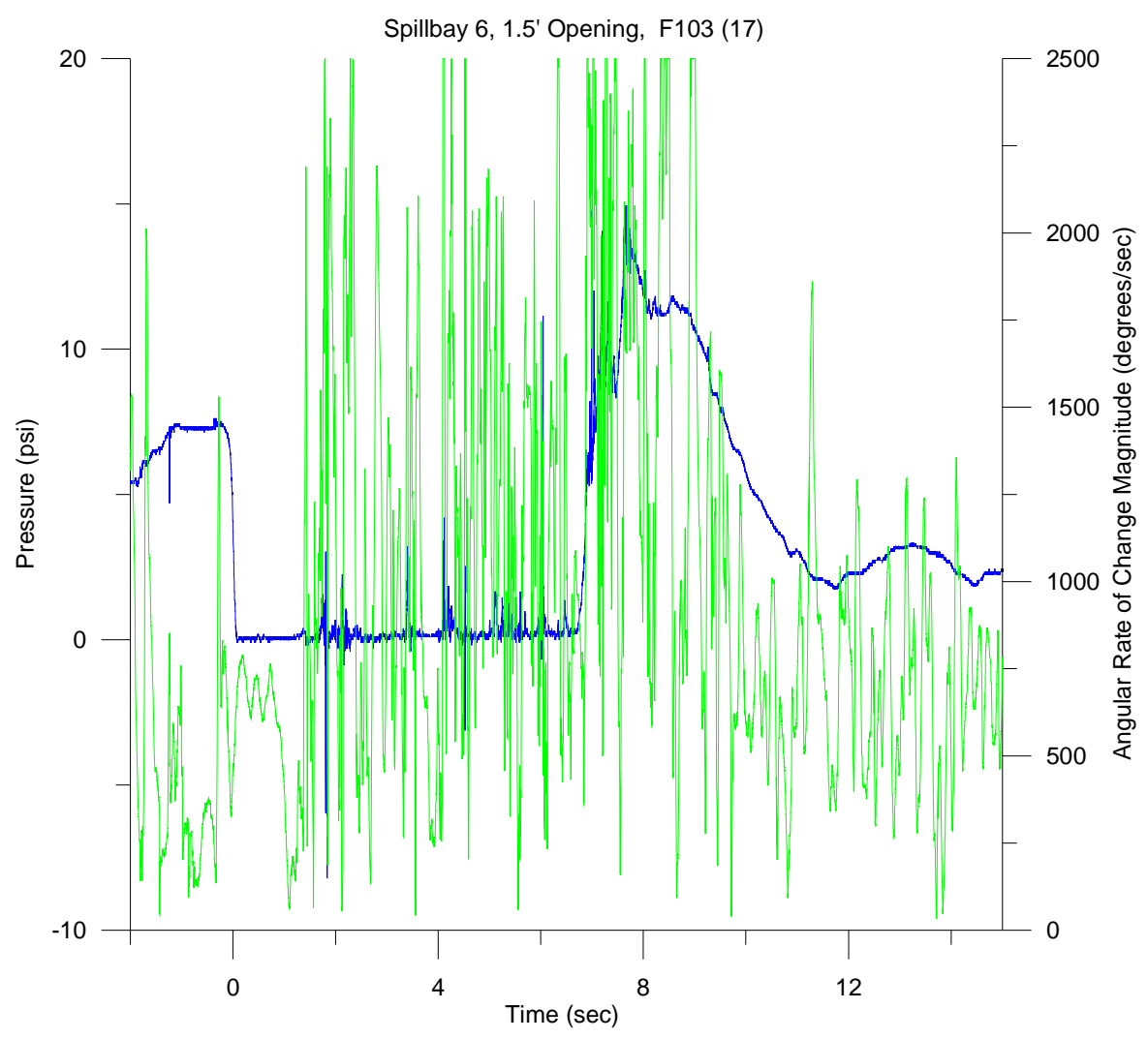




\section{Spillbay 6, 3.5 ft Tainter Gate Opening}



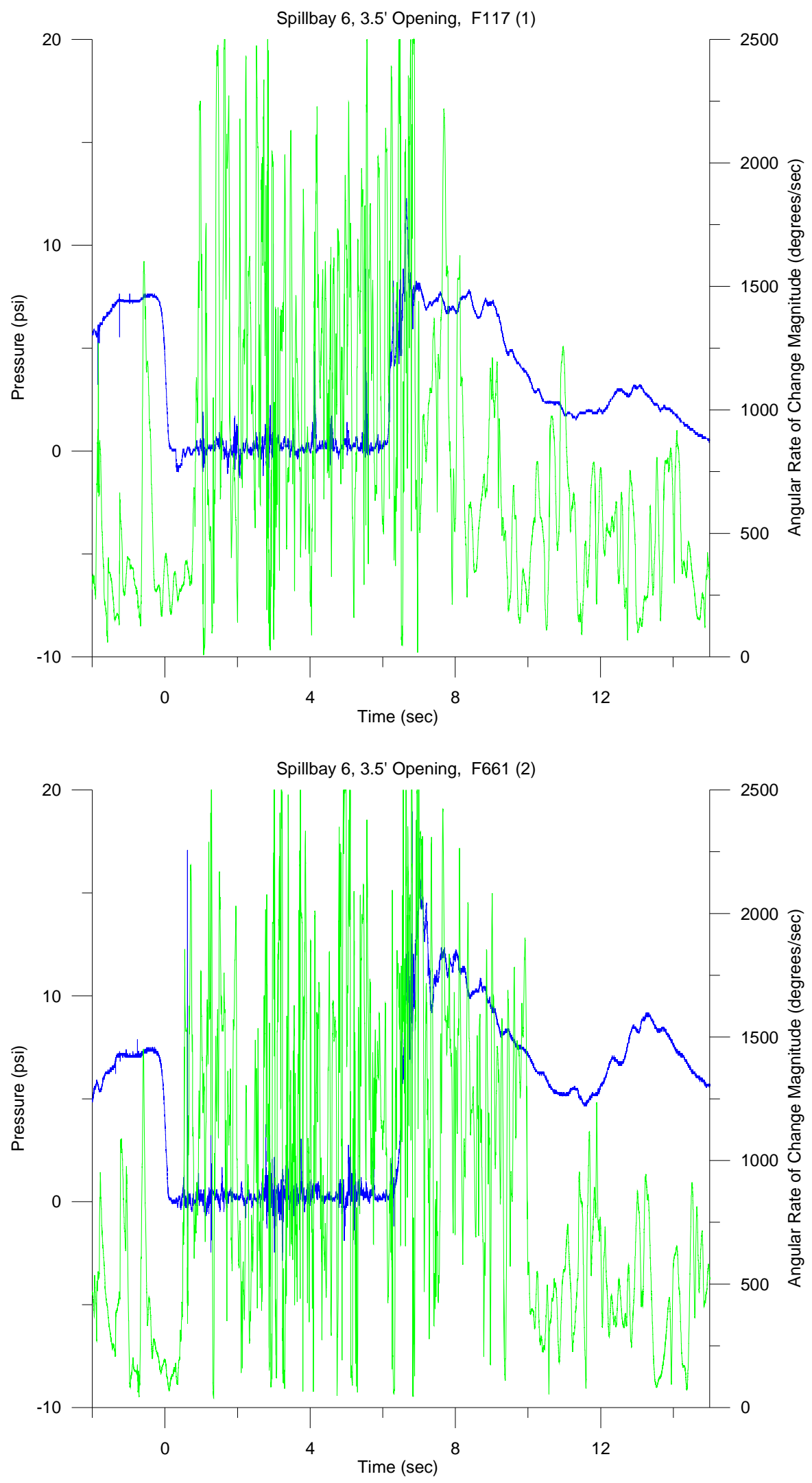

D.35 

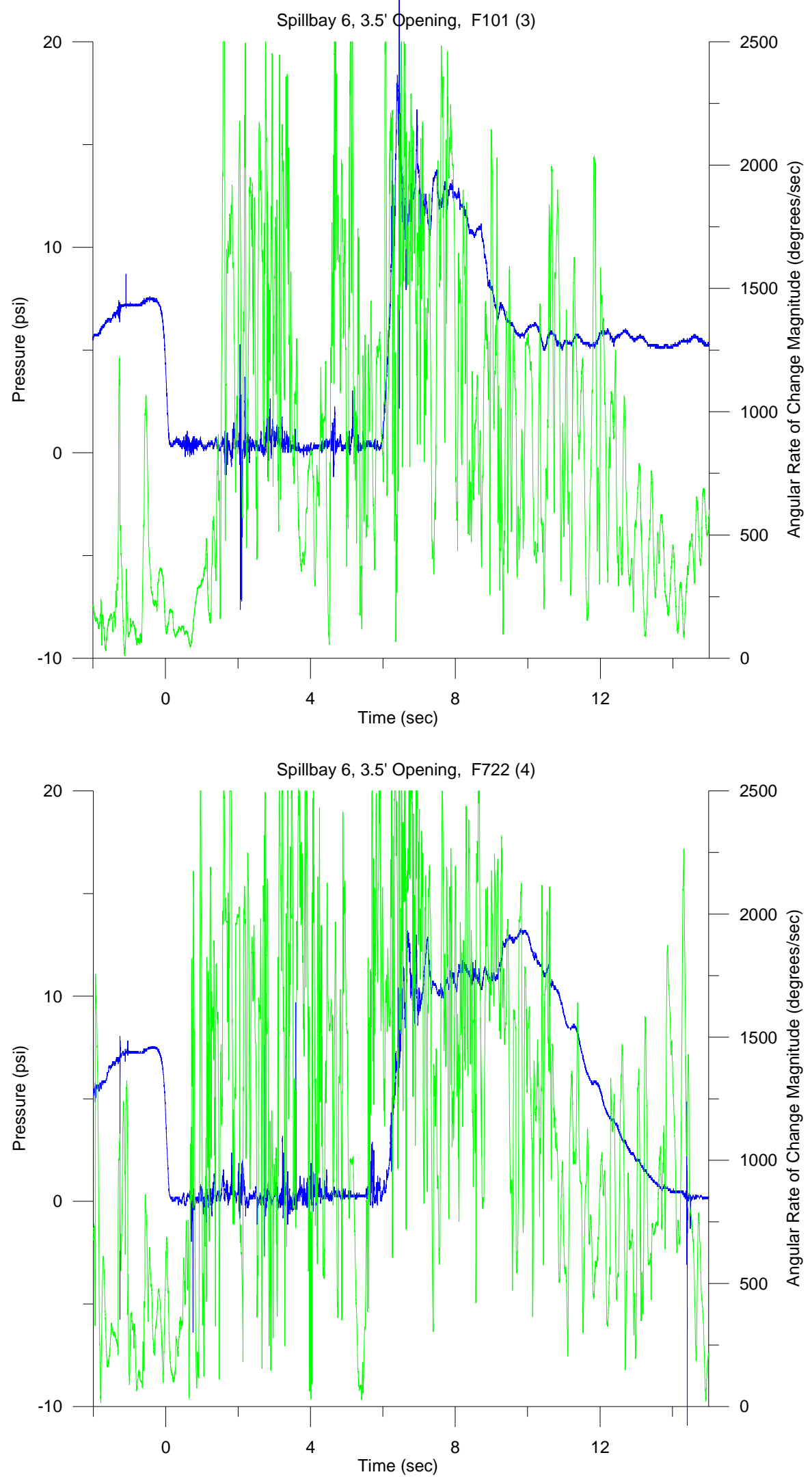

D.36 

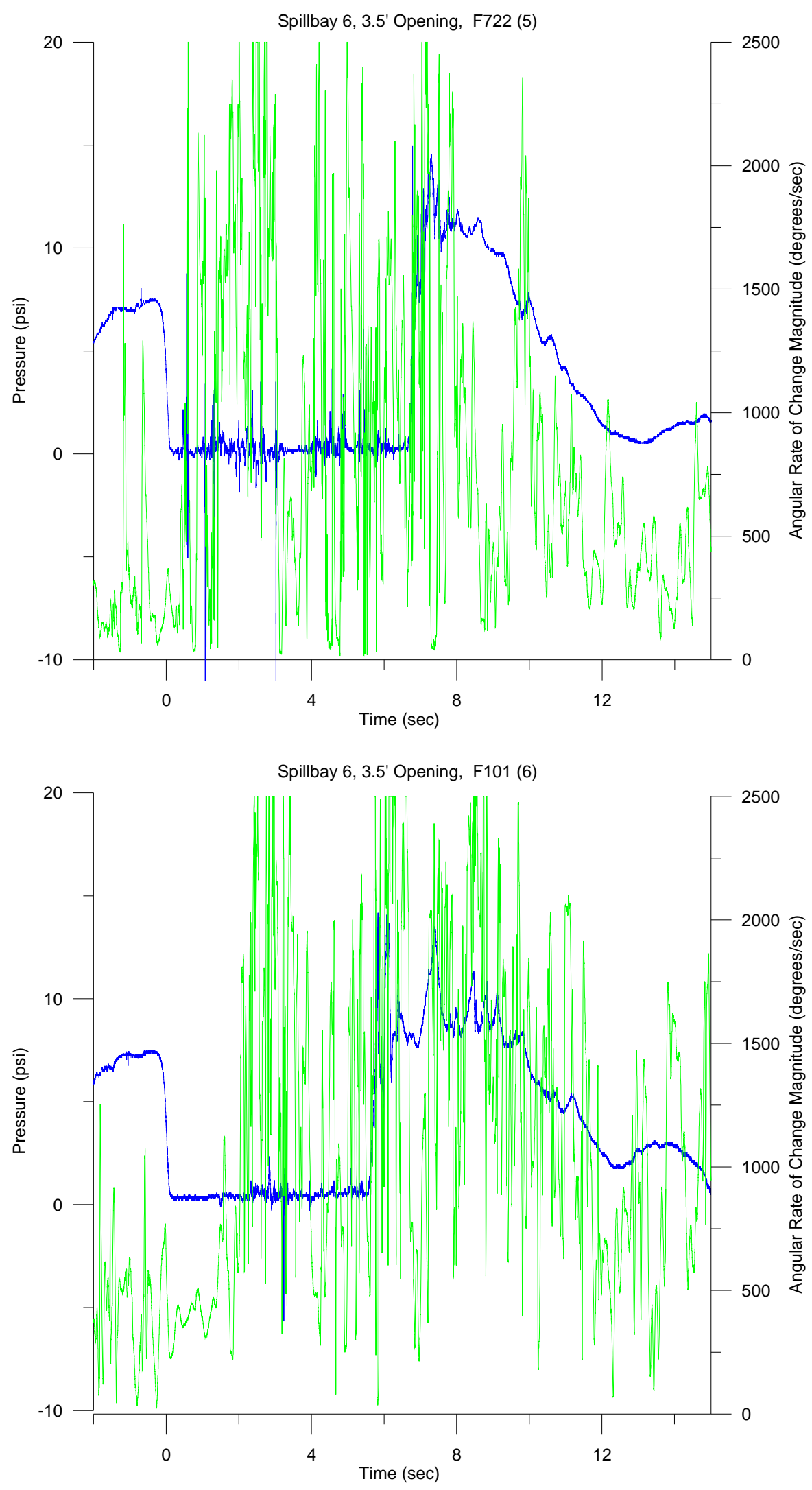

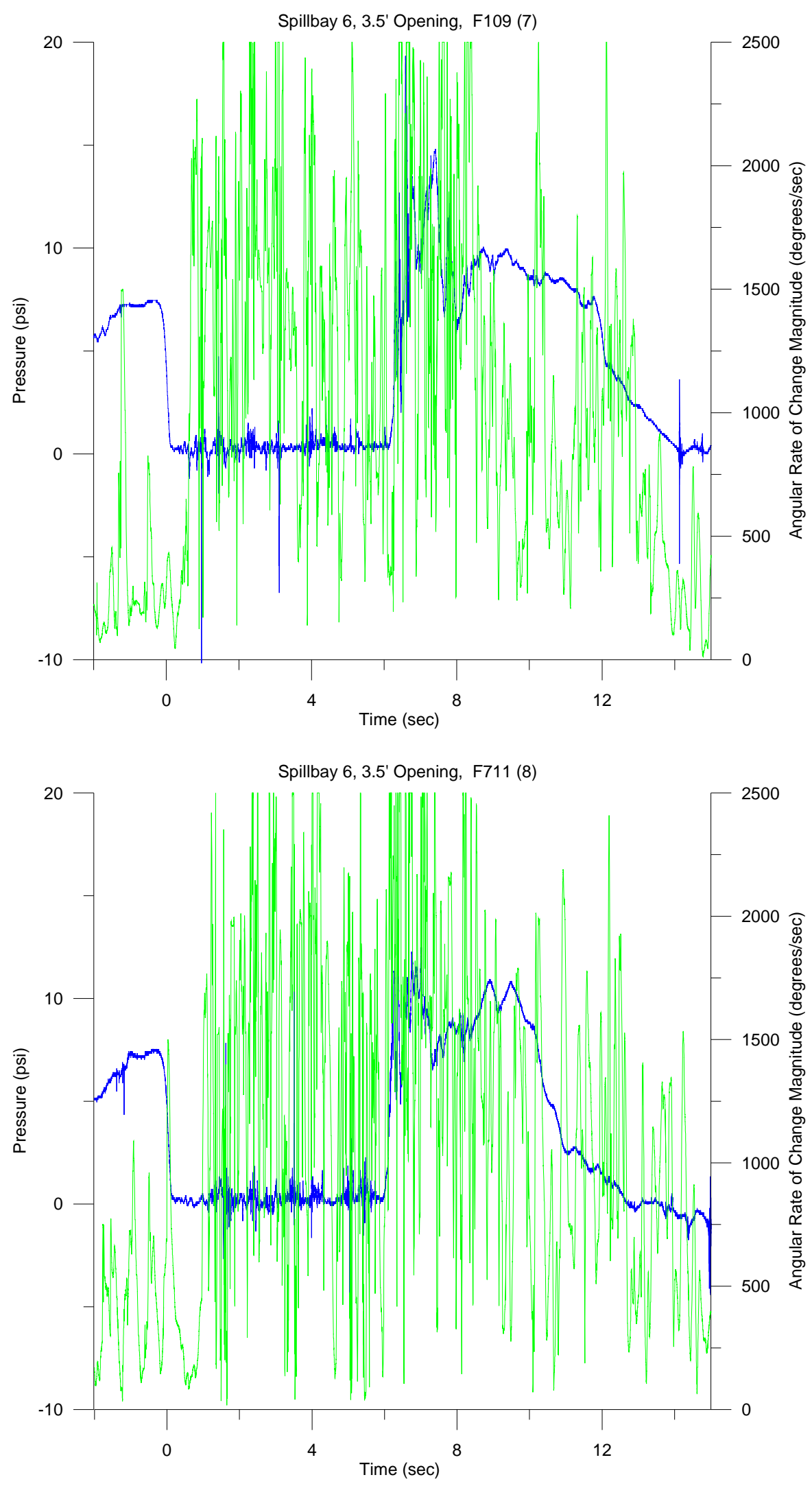

D.38 

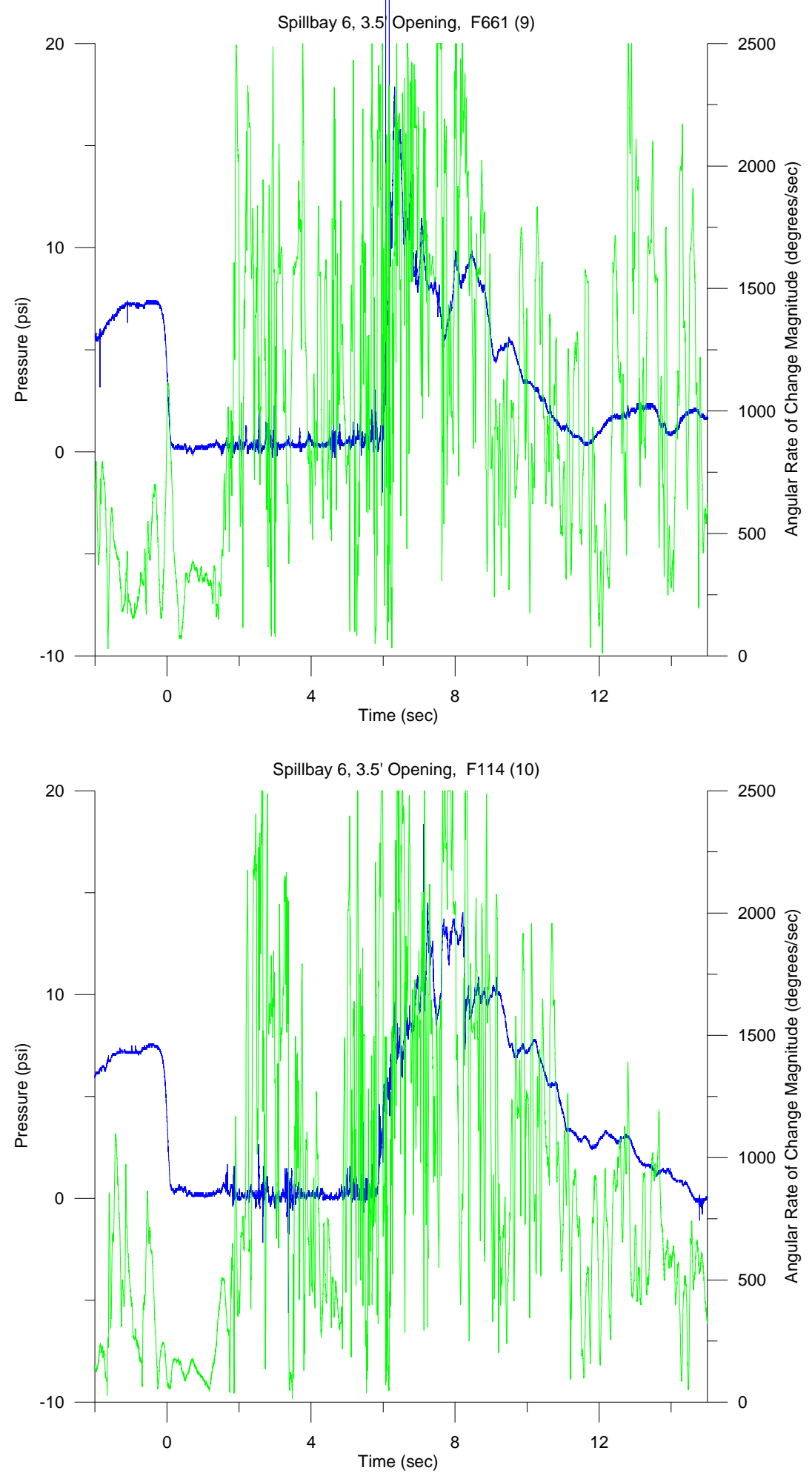

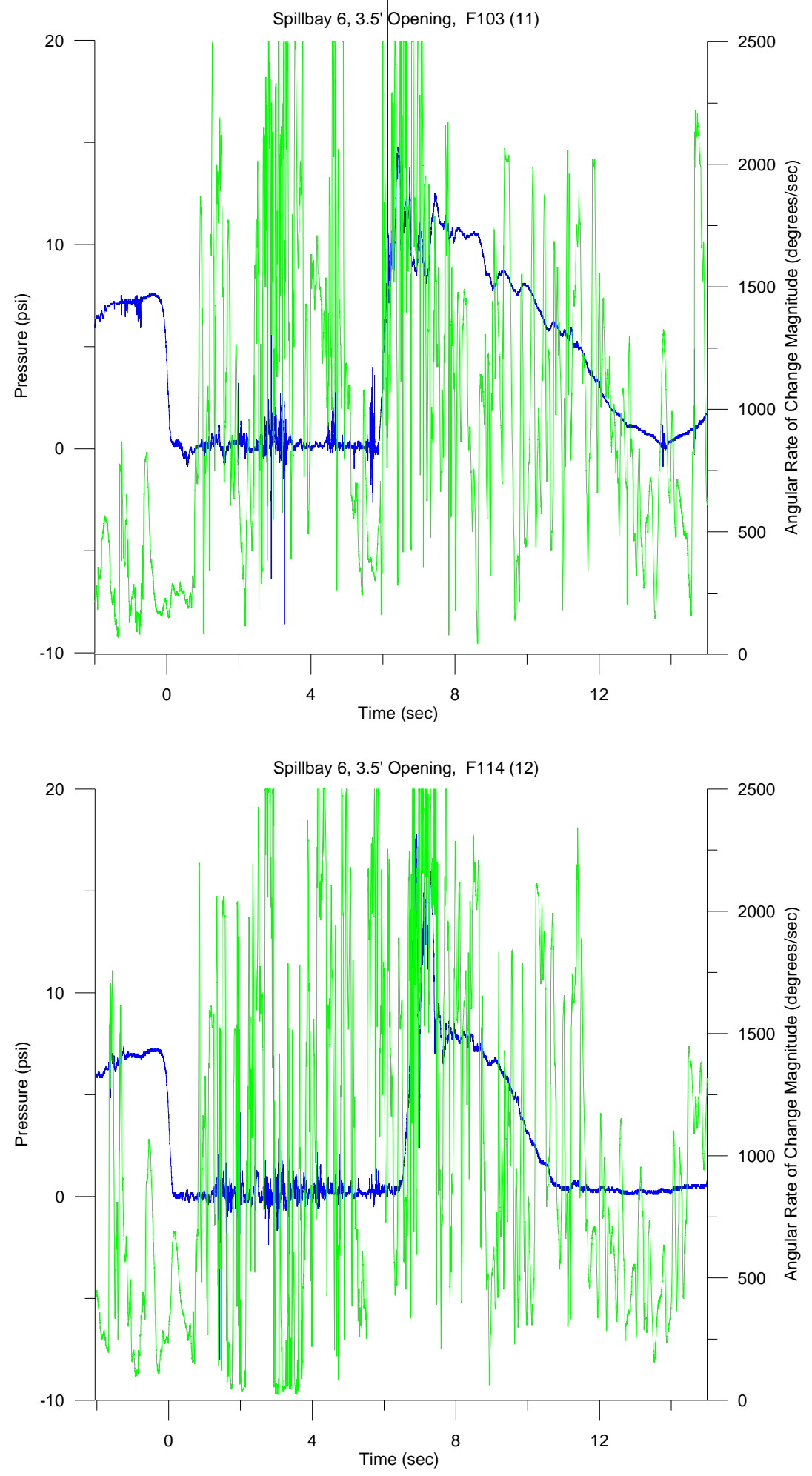

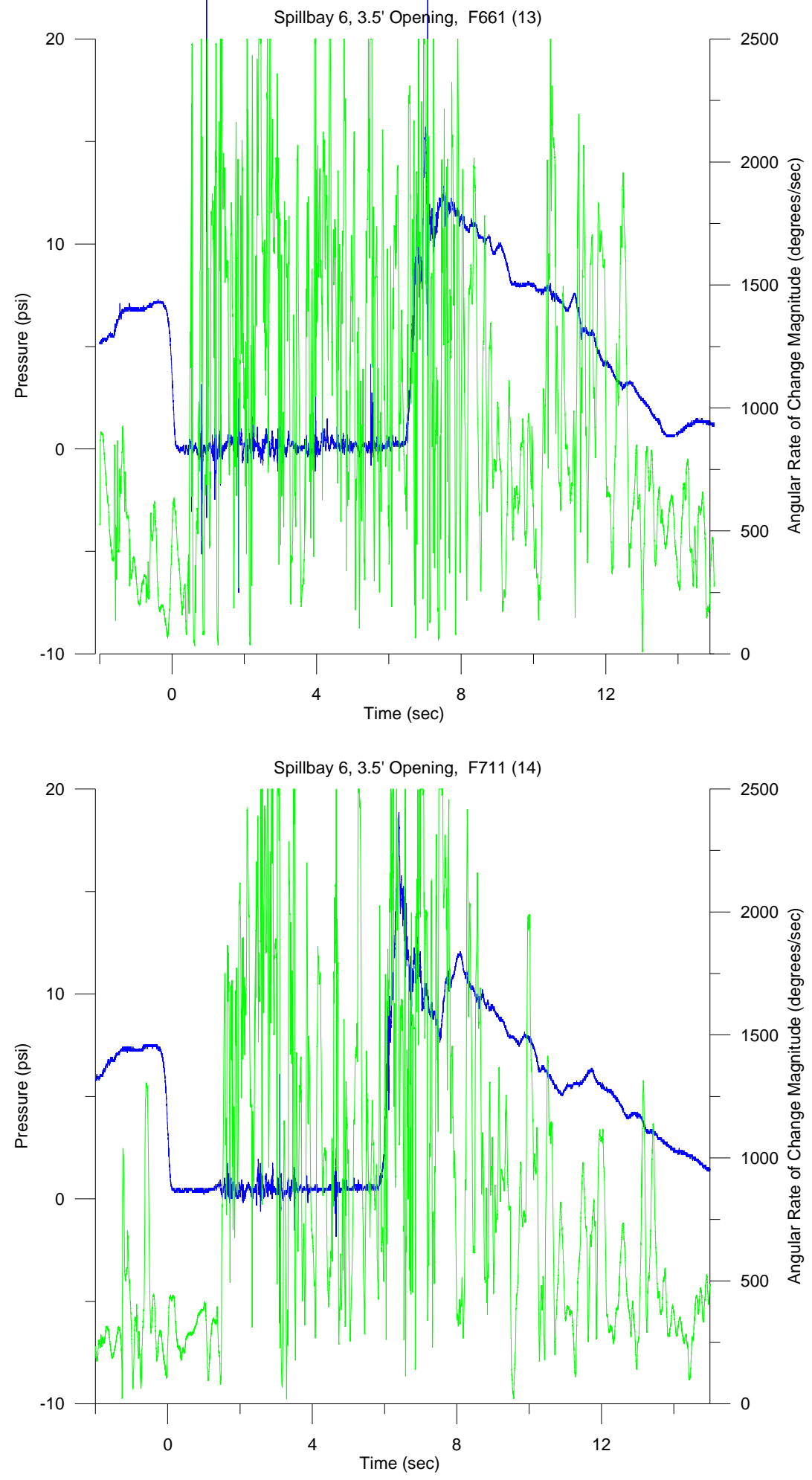

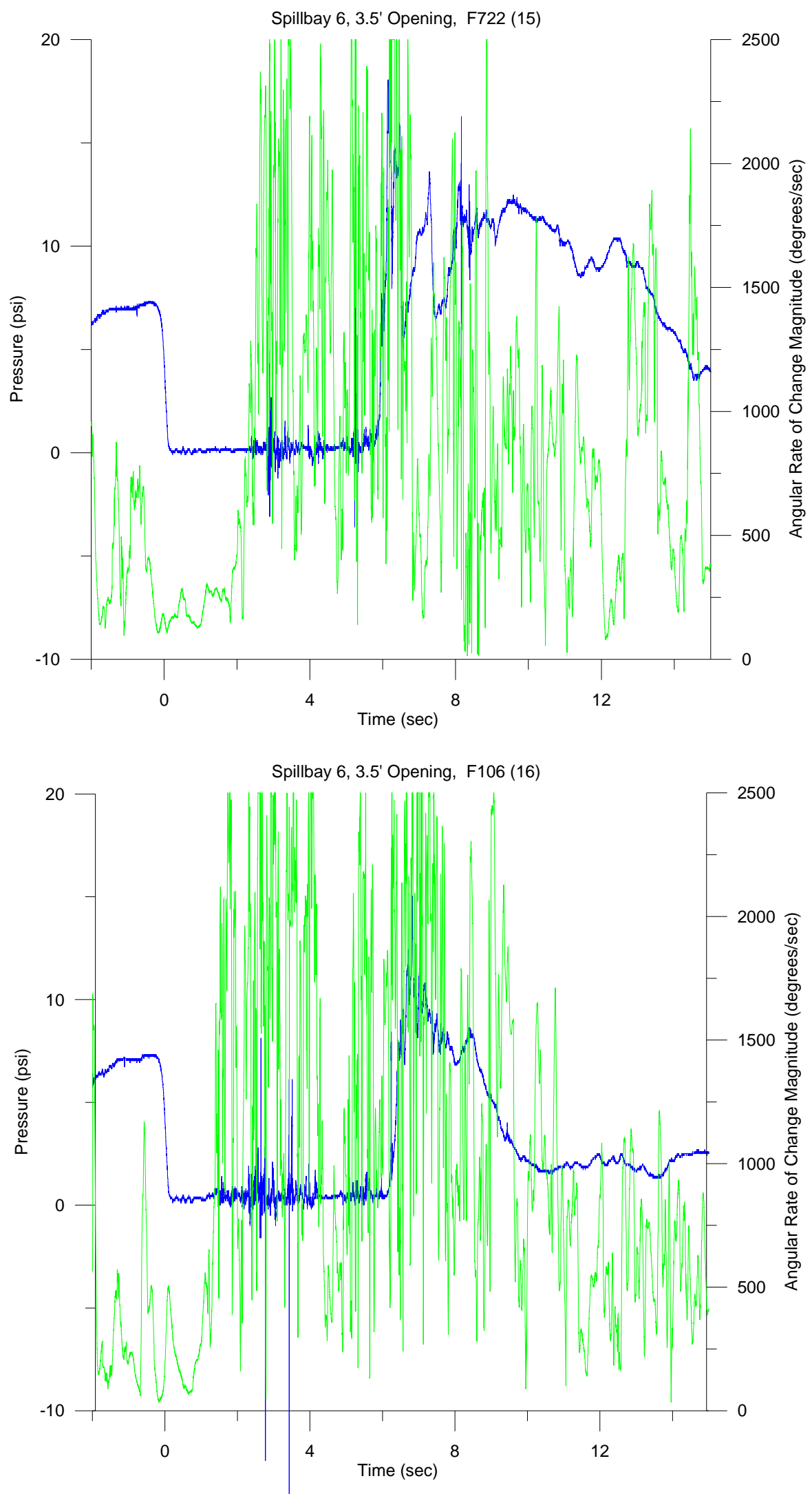

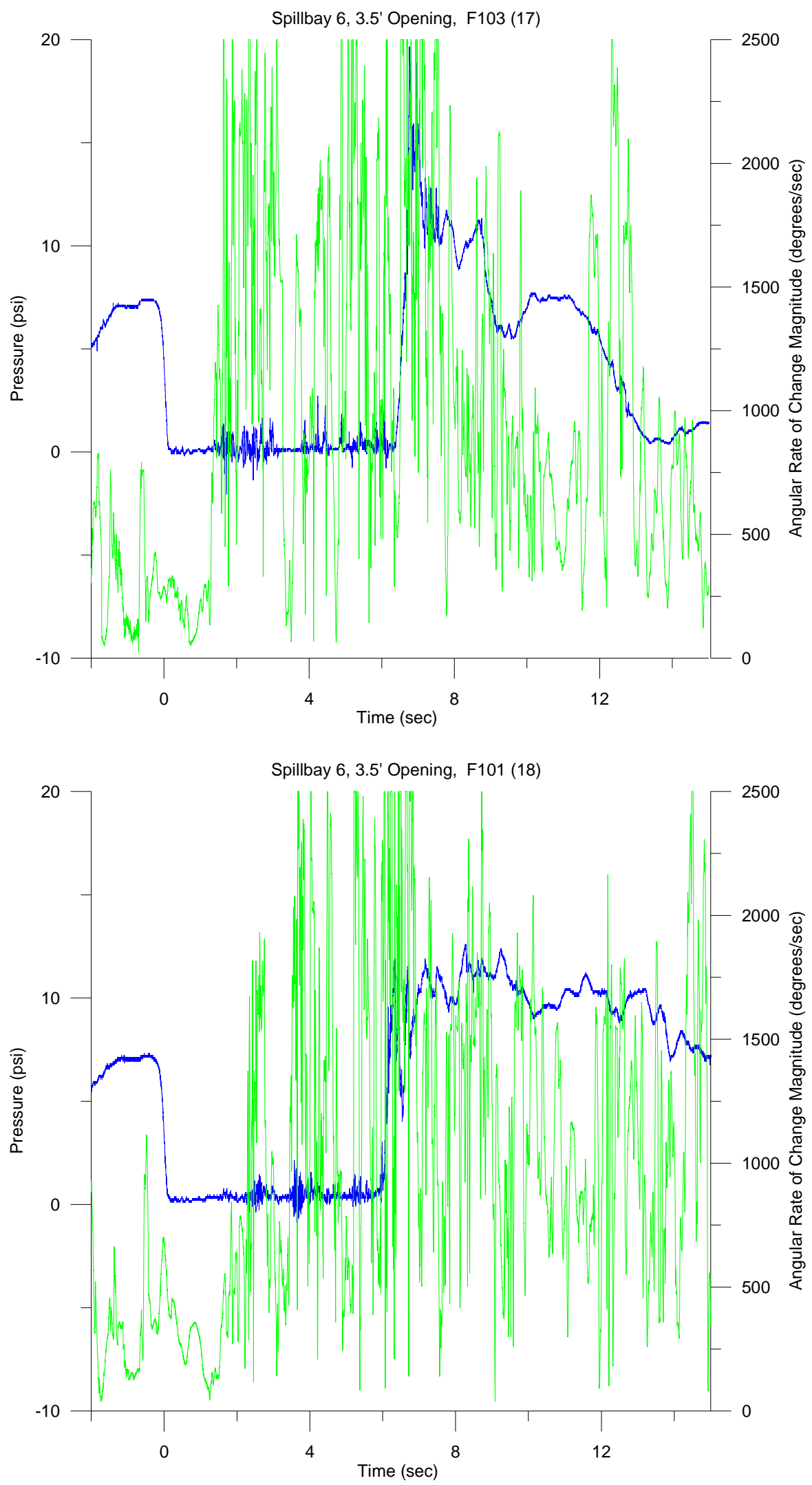

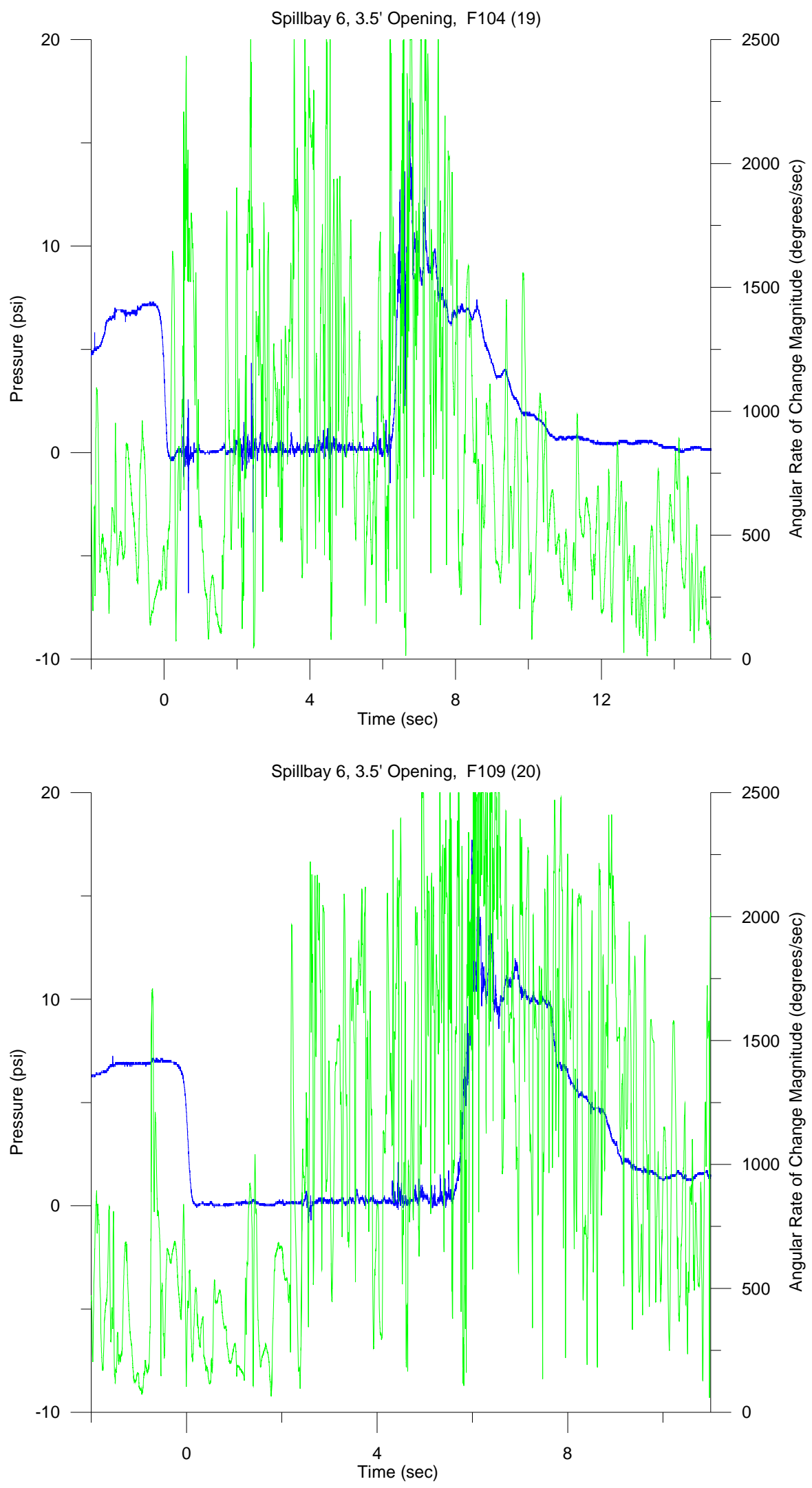

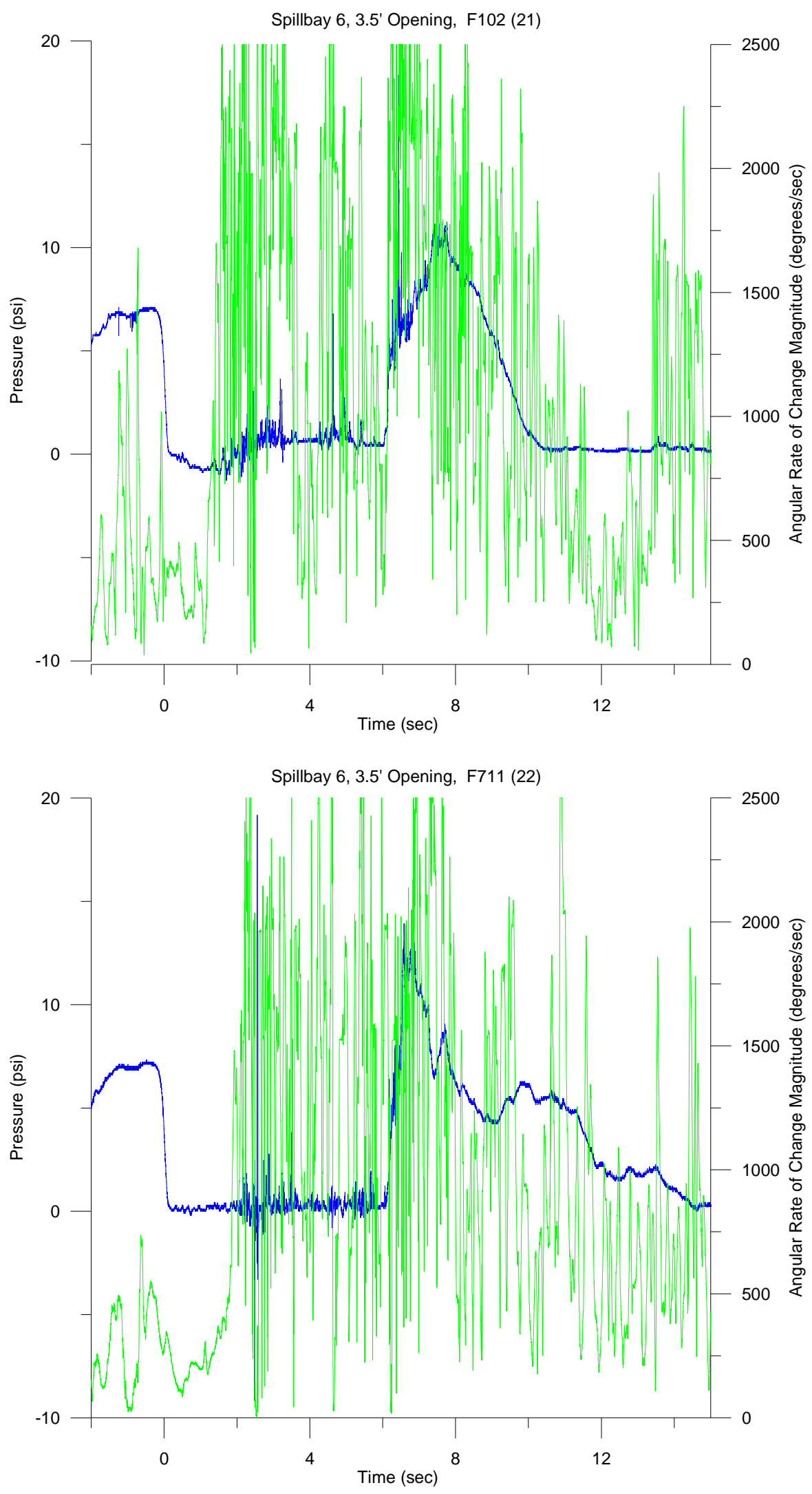

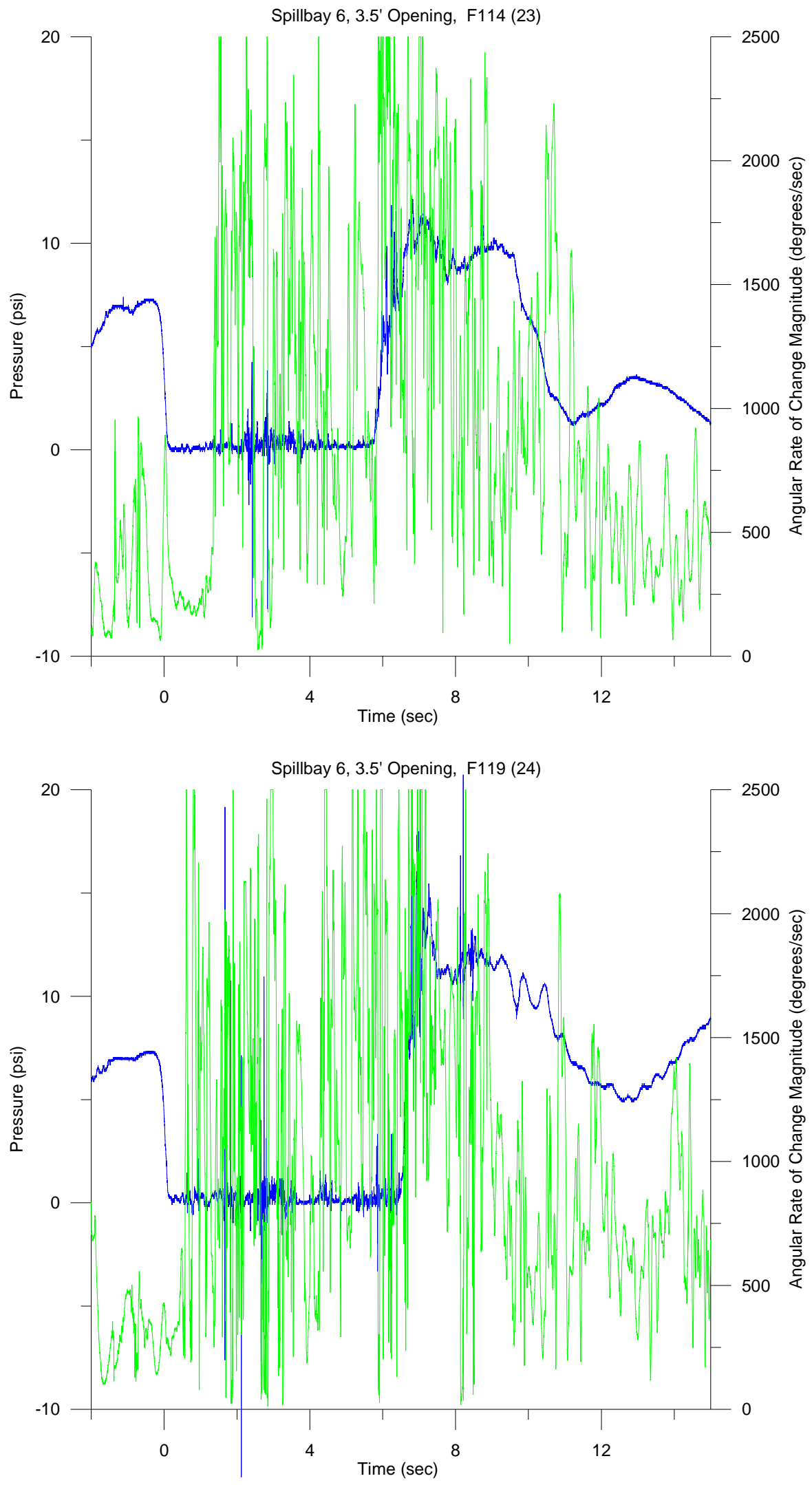


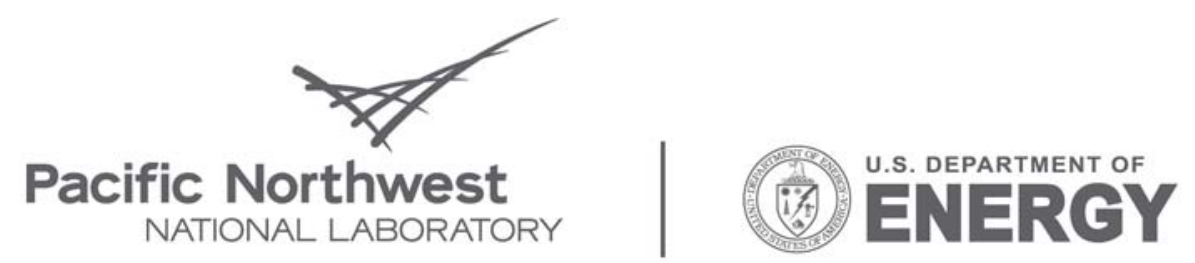

Proudly Operated by Battelle Since 1965

902 Battelle Boulevard

P.O. Box 999

Richland, WA 99352

1-888-375-PNNL (7665)

www.pnl.gov 